Prepared in cooperation with Douglas County, U.S. Environmental Protection Agency, the cities of Aurora, Northglenn, Thornton, and Westminster, the Colorado Department of Public Health and Environment, Colorado River Water Conservation District, Colorado Springs Utilities, Denver Water, Federal Emergency Management Agency, North Front Range Water Quality Planning Association, and Routt and Medicine Bow National Forests

\title{
Analysis of Postfire Hydrology, Water Quality, and Sediment Transport for Selected Streams in Areas of the 2002 Hayman and Hinman Fires, Colorado
}

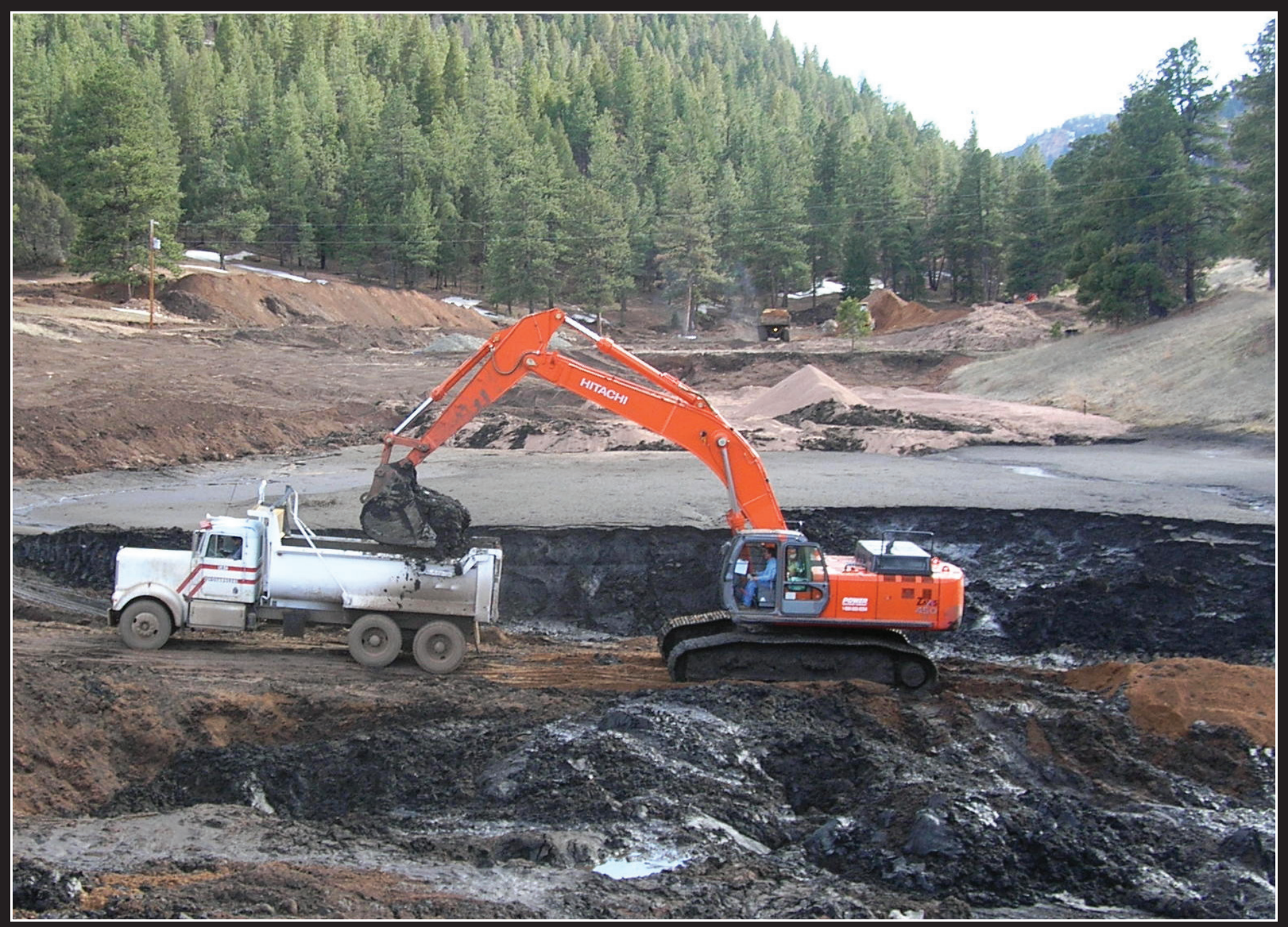

Scientific Investigations Report 2012-5267 
Front cover: Photograph of removal of an estimated 30,000 cubic yards (estimated to be about 44,000 tons) of post-Hayman Fire sediment and debris accumulated from November 2002 to March 2005 from the YMCA Camp Shady Brook swimming pond (Lake Kiwanis) (Photograph taken by Greg Smith, U.S. Geological Survey, April 2005).

Back cover: Top, Flood debris and sediment filled box-culvert on Trail Creek just upstream from the confluence with West Creek, at West Creek; and bottom, West Creek Lake after July 7, 2006 post-Hayman Fire flood filled the reservoir with sediment and debris; white survey rod indicates maximum height of water in the lake during the flood (streamflow increased from 62 to $2,170 \mathrm{ft}^{3} / \mathrm{s}$ in $45 \mathrm{minutes}$ at the dam). Photographs by Mike Stevens, U.S. Geological Survey, taken July 12, 2006. 


\section{Analysis of Postfire Hydrology, Water Quality, and Sediment Transport for Selected Streams in Areas of the 2002 Hayman and Hinman Fires, Colorado}

By Michael R. Stevens

Prepared in cooperation with Douglas County, U.S. Environmental Protection Agency, the cities of Aurora, Northglenn, Thornton, and Westminster, the Colorado Department of Public Health and Environment, Colorado River Water Conservation District, Colorado Springs Utilities, Denver Water, Federal Emergency Management Agency, North Front Range Water Quality Planning Association, and Routt and Medicine Bow National Forests

Scientific Investigations Report 2012-5267 


\title{
U.S. Department of the Interior SALLY JEWELL, Secretary
}

\section{U.S. Geological Survey Suzette M. Kimball, Acting Director}

\author{
U.S. Geological Survey, Reston, Virginia: 2013
}

For more information on the USGS - the Federal source for science about the Earth, its natural and living resources, natural hazards, and the environment, visit http://www.usgs.gov or call 1-888-ASK-USGS.

For an overview of USGS information products, including maps, imagery, and publications, visit http://www.usgs.gov/pubprod

To order this and other USGS information products, visit http://store.usgs.gov

Any use of trade, firm, or product names is for descriptive purposes only and does not imply endorsement by the U.S. Government.

Although this information product, for the most part, is in the public domain, it also may contain copyrighted materials as noted in the text. Permission to reproduce copyrighted items must be secured from the copyright owner.

Suggested citation:

Stevens, M.R., 2013, Analysis of postfire hydrology, water quality, and sediment transport for selected streams in areas of the 2002 Hayman and Hinman fires, Colorado: U.S. Geological Survey Scientific Investigations Report 2012-5267, 93 p., http://dx.doi.org/10.3133/sir20125267.

ISSN 2328-0328 (online) 


\section{Contents}

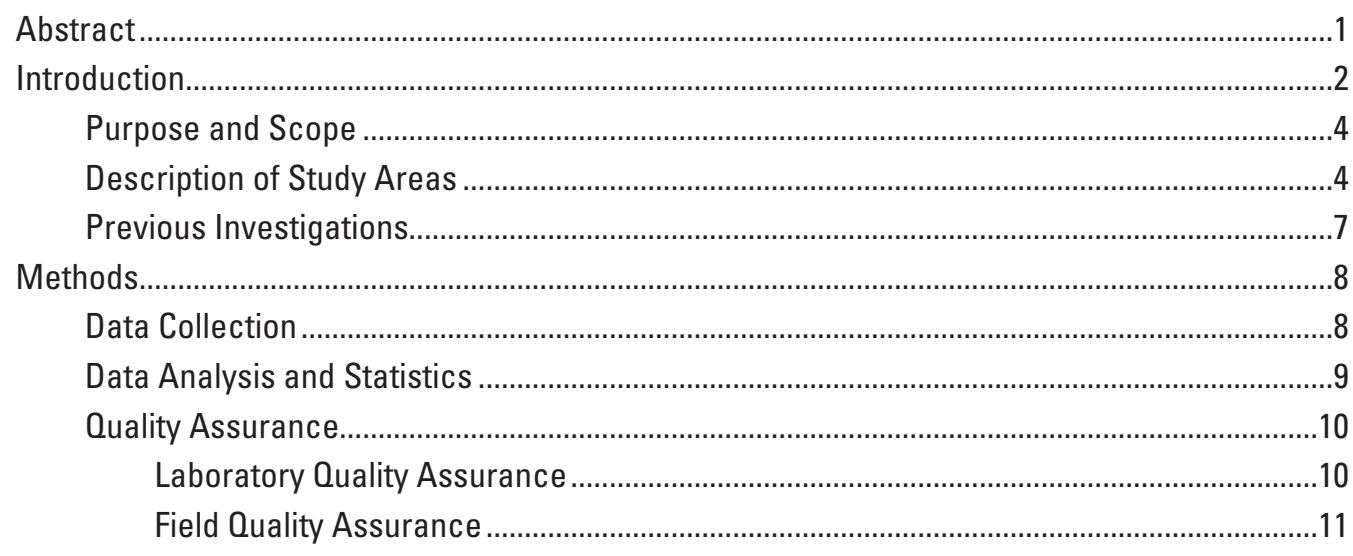

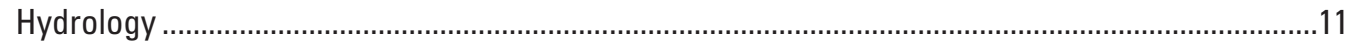

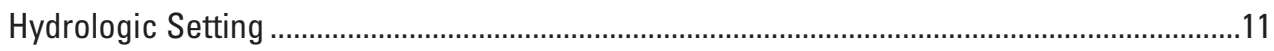

Hayman Fire Study Area ............................................................................................. 11

Hinman Fire Study Area .............................................................................................12

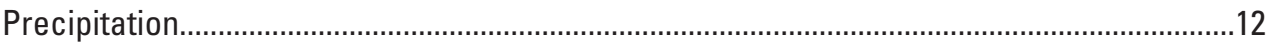

Hayman Fire Study Area ........................................................................................ 12

Hinman Fire Study Area ............................................................................................. 13

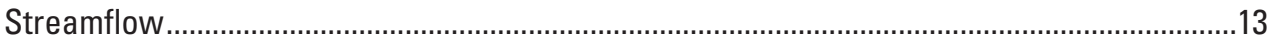

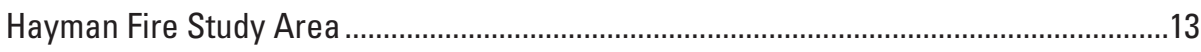

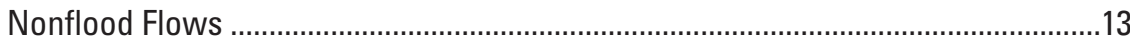

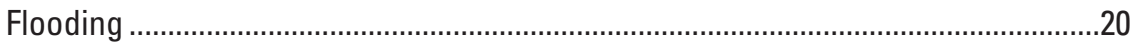

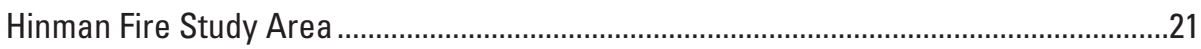

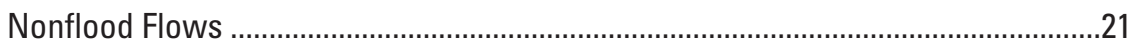

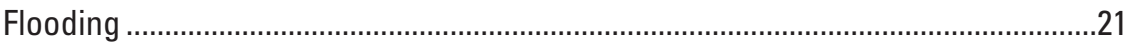

Comparison of Hayman and Hinman Fire Study Results...............................................24

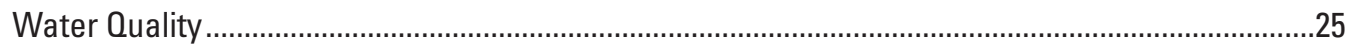

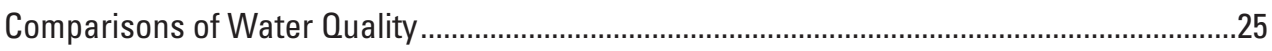

Hayman Fire Study Area ..................................................................................................25

Field and Laboratory Measurements and Major Ions ..............................................25

Nutrients and Organic Carbon.................................................................................27

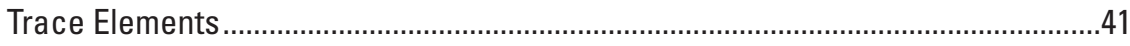

Hinman Fire Study Area ................................................................................................ 43

Field and Laboratory Measurements and Major Ions ..............................................43

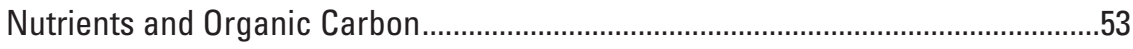

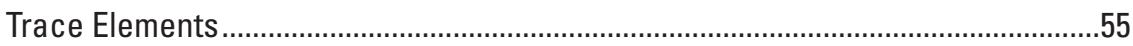

Comparison of Hayman and Hinman Fire Study Results ................................................55

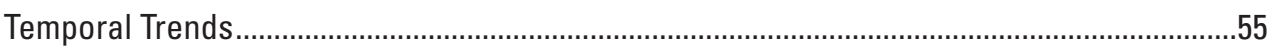

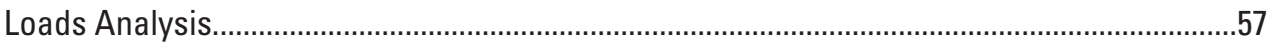

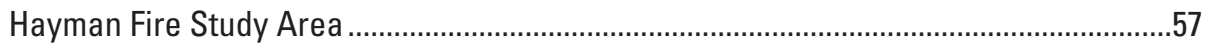

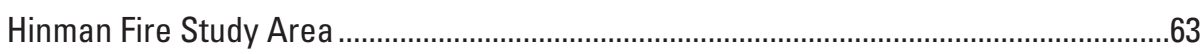

Comparison of Hayman and Hinman Fire Study Results ..............................................63 


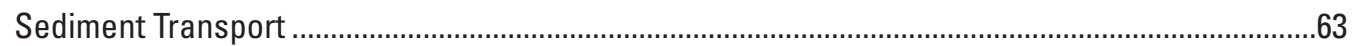

Sources and Storage .......................................................................................................63

Comparisons of Burned and Unburned Study Areas...........................................................63

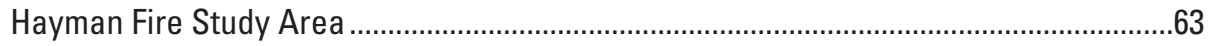

Hinman Fire Study Area ................................................................................................68

Comparison of Hayman and Hinman Fire Study Results ................................................69

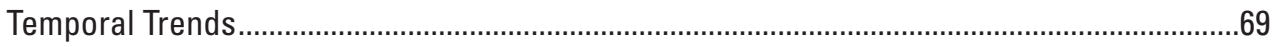

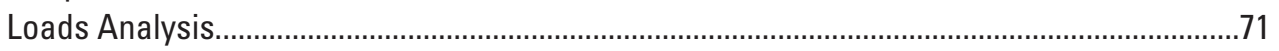

Hayman Fire Study Area .......................................................................................

Hinman Fire Study Area .............................................................................................71

Comparison of Hayman and Hinman Fire Study Results ...................................................71

Potential Effects and Consequences to Postfire Water Quality .................................................72

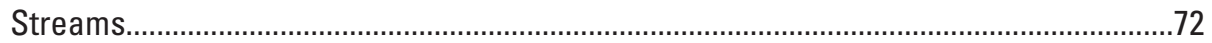

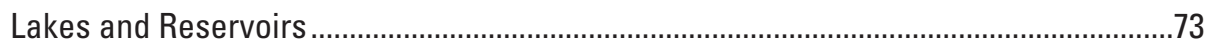

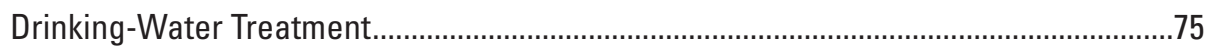

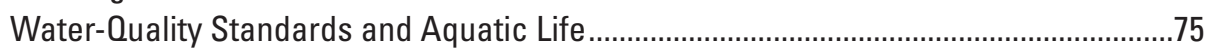

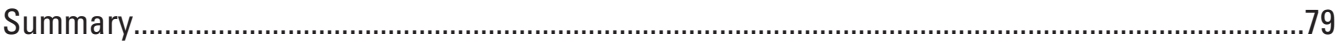

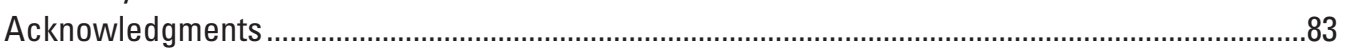

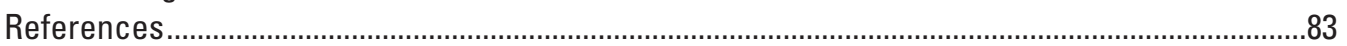

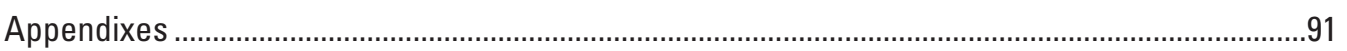

\section{Figures}

1. Map showing location of Colorado streams and sampling sites affected by the Hayman and Hinman fires.

2. Photograph of the Mad Creek fire in 2001 burning as an intense surface fire in blowdown in the upper Mad Creek watershed. .7

3. Graph showing a 20-year time-series (1988-2007) of annual snowfall and annual total precipitation for the National Oceanic and Atmospheric Administration Cheesman weather station.

4. Graph showing mean monthly snowfall and total precipitation for the National Oceanic and Atmospheric Administration Cheesman weather station, 1948 through 2006

5. Map showing estimated rainfall distribution based on Doppler radar data and precipitation gages for May 30, 2003, storm over Hayman burn area

6. Graph showing cumulative precipitation and streamflow at the West Creek streamgage for the period July 8 through July 12, 2006.

7. Graph showing annual total precipitation for the Lost Dog SNOTEL site for 1999 through 2009

8. Graph showing distribution of average monthly precipitation at the Lost Dog SNOTEL site for the period 1999 through 2009.

9. Graph showing daily total precipitation, snow-water equivalent at Lost

Dog SNOTEL station, 2003 compared to 1999 through 2009 average..

10. Graph showing instantaneous streamflow measured during water-quality sampling at Fourmile Creek and Pine Creek, 2003 through 2007

11. Graph showing distribution of monthly mean streamflow (April through September) at Fourmile Creek, 2003 and 2004 ...

12. Hydrograph showing daily mean at Fourmile Creek, 2003 through 2004 
13. Graph showing annual mean streamflow difference between South Platte River below Cheesman Lake and South Platte River below Brush Creek near Trumbull streamgages, 2003 through 2007.

14. Graph showing distribution of monthly mean streamflow differences between South Platte River below Cheesman Lake and the South Platte River below Brush Creek near Trumbull streamgages, 2003 through 2007

15. Estimated 100 -year flood hydrograph for Fourmile Creek based on hydrologic modeling

16. Photographs of flooding May 30, 2003, along Fourmile Creek downstream from YMCA Camp Shady Brook; Horse Creek at mouth at Deckers; Fourmile Creek at mouth at South Platte River; and South Platte River below Brush Creek near Trumbull

17. Photographs of damage from flood of July 7, 2006, along West Creek and Trail Creek

18. Graph showing daily mean streamflow at seasonal streamgage at Elk River above Clark, Colorado, 1998 through 2003

19. Graph showing annual mean streamflow at Elk River above Clark, Colorado, for the period of record, (April-September) 1989-1993 and 1998-2003

20. Graph showing monthly mean streamflow at Elk River above Clark, Colorado, for the period of record, 1988-1993

21. Graphs showing instantaneous streamflow measured during water-quality sampling at North Fork Elk River and Lost Dog Creek, 1999-2006

22. Photograph of flooding from snowmelt runoff on May 29, 2003 (postHinman fire), showing creek overtopping Forest Service road at 174 cubic feet per second in the 3.2 square-mile watershed of Lost Dog Creek

23. Graph showing relation of annual peak streamflow (instantaneous) with snow-water equivalent (April 1) at Elk River above Clark, 1999 through 2003.

24. Boxplots showing distribution of concentrations of selected water-quality constituents at Fourmile Creek, Pine Creek, Lost Dog Creek, and North Fork Elk River, 1999-2007.

25. Boxplots showing distribution of loads normalized to drainage area for selected water-quality constituents at Fourmile Creek, Pine Creek, Lost Dog Creek, and North Fork Elk River, 1999-2007.

26. Graphs showing concentrations of selected water-quality constituents at Fourmile Creek (burned) and Pine Creek (unburned), Colorado, 2003-2007

27. Graphs showing instantaneous loads of selected water-quality constituents at Fourmile Creek (burned) and Pine Creek (unburned), Colorado, 2003-2007

28. Photographs of postfire algal growth along Fourmile Creek and South

Platte River, about 4 miles north of Deckers, Colorado, during summer (2003) of the first full postfire year

29. Graphs showing concentrations of selected water-quality constituents at Lost Dog Creek, 1999-2006

30. Graphs showing concentrations of selected water-quality constituents at North Fork Elk River, 1999-2006.

31. Graphs showing loads of selected water-quality constituents at Lost Dog Creek, 1999-2006.

32. Graphs showing loads of selected water-quality constituents at North Fork Elk River, 1999-2006. 
33. Graphs showing water-quality constituent concentration relations with streamflow for calcium; silica; nitrite plus nitrate; and suspended sediment at Lost Dog Creek..

34. Graphs showing loads of selected water-quality constituents computed for the April through September period during 1999 and 2003 at North Fork Elk River, and Lost Dog Creek and the April through September period during 2003 at Fourmile Creek, Pine Creek, and South Platte River near Trumbull.

35. Photographs of sediment sources and storage, Hayman fire area 64

36. Boxplots showing comparison of suspended-sediment concentrations and loads for all sites

37. Graphs showing time-series of instantaneous suspended-sediment concentrations and loads at Fourmile and Pine Creeks, 2003 through 2007

38. Photographs of removal of an estimated 30,000 cubic yards (estimated to be about 44,000 tons) postfire sediment accumulated from November 2002 to March 2005 from the YMCA Camp Shady Brook swimming pond (Kiwanis Lake)...

39. Graph showing daily mean, daily maximum turbidity, and daily mean streamflow at South Platte River below Brush Creek near Trumbull, 2003

40. Graphs showing time-series of instantaneous suspended-sediment concentrations and loads at Lost Dog Creek and North Fork Elk River, 1999 through 2006

41. Photograph of silted-in debris dam (42 feet high) constructed by Denver Water on Turkey Creek (a tributary that enters Cheesman Lake) to retain sediment transported after the Hayman fire

42. Photograph of postfire algae growth in Kiwanis Lake at YMCA Camp Shady Brook 73

43. Photograph of postfire debris and suspended sediment from July 7, 2006, flood in West Creek Lake at West Creek, Colorado

44. Photograph of debris in Strontia Springs Reservoir from postfire flood after the Buffalo Creek fire.

\section{Tables}

1. Collection and analysis methods for water-quality properties and constituents ..............5

2. Watershed characteristics for stream sites referenced in this report ..............................6

3. Results of Wilcoxon signed-rank test of differences between paired samples (nonstorm only) of water-quality measurements, concentrations, and loads normalized to drainage area at Fourmile and Pine Creeks, 2003-2007.

4. Seasonal Kendall trend-analysis results for LOWESS streamflow-adjusted water-quality measurements and constituent concentrations at Fourmile Creek, 2003-2007.

5. Seasonal Kendall trend-analysis results for LOWESS streamflow-adjusted water-quality measurements and constituent concentrations at Pine Creek, 2003-2007.

6. Results of low-level mercury analysis at selected Hayman sampling sites on October 27, 2004 
7. Mann-Whitney test of differences between prefire (1999-2000) and postfire (2003) water-quality measurements, concentrations, and loads normalized to drainage area at Lost Dog Creek

8. Mann-Whitney test of differences between prefire (1999-2000) and postfire (2003) water-quality measurements, concentrations, and loads normalized to drainage area at North Fork Elk River.

9. Mann-Whitney test of postburn first-postfire year differences between Fourmile Creek (2003) and Lost Dog Creek (2003) water-quality measurements and constituent concentrations and instantaneous loads normalized to drainage area

10. Seasonal Kendall trend-analysis results for streamflow-weighted waterquality measurements and constituent loads (not LOWESS-adjusted for streamflow) at Fourmile Creek (2003-2007).

11. Seasonal Kendall trend-analysis results for streamflow-weighted waterquality measurements and constituent loads (not LOWESS-adjusted for streamflow) at Pine Creek (2003-2007)

12. Selected water-quality constituent loads for the April through September 2003 period at Fourmile Creek and Pine Creek and the 1999 and 2003 periods at North Fork Elk River and Lost Dog Creek

13. Water-quality standards and exceedances of Colorado stream standards for sampling sites in this study

\section{Appendixes}

1. Field measurements, concentrations, loads, and flow-weighted measurements for Fourmile, Pine, South Platte Trumbull, Lost Dog, North Fork Elk, and Mad Creek sampling sites, 1999-2007 Link

2. Statistics for concentrations, measurement values, loads, and flow-weighted measurements at water-quality sampling sites, 1999-2007 Link

3. Tentatively identified organic compounds detected in water samples for selected sites Link

4. Tentatively identified organic compounds detected in bed-sediment samples for selected sites

5. Statistics for computed relative percent differences among sequential replicates collected during the study...

6. Selected statistics for field blank samples Link

7. Trihalomethane formation (THM) potential concentrations from selected sites in the Hayman and Hinman fire study areas and streams in the Missionary Ridge fire area west of Durango, Colorado

8. Concentrations of target organic compounds in water samples collected at selected sites

9. Concentrations of trace elements detected in bed-sediment samples collected from selected sites

10. Supplemental data collected by the U.S. Department of Agriculture Forest Service before and after the June 2002 Hayman fire

11. Comparison of Hayman and Hinman fire study areas' minimum, median, and maximum concentrations and loads, April through September 2003 (first year after fire)

12. Location of Mad Creek water-quality sampling site south of North Fork Elk River near mouth near Clark, Colorado 


\section{Conversion Factors}

Inch/Pound to SI

\begin{tabular}{|c|c|c|}
\hline Multiply & By & To obtain \\
\hline \multicolumn{3}{|c|}{ Length } \\
\hline inch (in.) & 25.4 & millimeter (mm) \\
\hline foot $(\mathrm{ft})$ & 0.3048 & $\operatorname{meter}(\mathrm{m})$ \\
\hline mile (mi) & 1.609 & kilometer $(\mathrm{km})$ \\
\hline \multicolumn{3}{|c|}{ Area } \\
\hline square mile $\left(\mathrm{mi}^{2}\right)$ & 2.590 & square kilometer $\left(\mathrm{km}^{2}\right)$ \\
\hline square mile $\left(\mathrm{mi}^{2}\right)$ & 258. & hectare \\
\hline \multicolumn{3}{|c|}{ Volume } \\
\hline acre-foot (acre-ft) & 1,233 & cubic meter $\left(\mathrm{m}^{3}\right)$ \\
\hline acre-foot (acre-ft) & 0.001233 & cubic hectometer $\left(\mathrm{hm}^{3}\right)$ \\
\hline \multicolumn{3}{|c|}{ Flow rate } \\
\hline acre-foot per day (acre-ft/d) & 0.01427 & cubic meter per second $\left(\mathrm{m}^{3} / \mathrm{s}\right)$ \\
\hline cubic foot per second $\left(\mathrm{ft}^{3} / \mathrm{s}\right)$ & 0.02832 & cubic meter per second $\left(\mathrm{m}^{3} / \mathrm{s}\right)$ \\
\hline \multicolumn{3}{|c|}{ Mass } \\
\hline ton, short $(2,000 \mathrm{lb})$ & 0.9072 & megagram (Mg) \\
\hline ton per day (ton/d) & 0.9072 & metric ton per day \\
\hline ton per day (ton/d) & 0.9072 & megagram per day $(\mathrm{Mg} / \mathrm{d})$ \\
\hline ton per square mile $\left(\mathrm{t} / \mathrm{mi}^{2}\right)$ & 258 & ton per hectare \\
\hline $\begin{array}{l}\text { ton per day per square mile } \\
{\left[(\text { ton } / \mathrm{d}) / \mathrm{mi}^{2}\right]}\end{array}$ & 0.3503 & $\begin{array}{l}\text { megagram per day per square kilometer } \\
\qquad\left[(\mathrm{Mg} / \mathrm{d}) / \mathrm{km}^{2}\right]\end{array}$ \\
\hline $\begin{array}{l}\text { ton per square mile per year } \\
\left.\text { [ton } / \mathrm{mi}^{2} / \text { year }\right]\end{array}$ & 2000 & $\begin{array}{l}\text { Pound per square mile per year } \\
\left.\quad \text { [pound } / \mathrm{mi}^{2} / \text { year }\right]\end{array}$ \\
\hline ton per day (ton/d) & 0.0005 & pound per day \\
\hline microgram per liter $(\mu \mathrm{g} / \mathrm{L})$ & 1,000 & milligram per liter $(\mathrm{mg} / \mathrm{L})$ \\
\hline
\end{tabular}

Temperature in degrees Celsius $\left({ }^{\circ} \mathrm{C}\right)$ may be converted to degrees Fahrenheit $\left({ }^{\circ} \mathrm{F}\right)$ as follows:

$$
{ }^{\circ} \mathrm{F}=\left(1.8 \times{ }^{\circ} \mathrm{C}\right)+32
$$

Temperature in degrees Fahrenheit $\left({ }^{\circ} \mathrm{F}\right)$ may be converted to degrees Celsius $\left({ }^{\circ} \mathrm{C}\right)$ as follows:

$$
{ }^{\circ} \mathrm{C}=\left({ }^{\circ} \mathrm{F}-32\right) / 1.8
$$

Vertical coordinate information is referenced to the North American Vertical Datum of 1988 (NAVD 88).

Horizontal coordinate information is referenced to the North American Datum of 1983 (NAD 83).

Elevation, as used in this report, refers to distance above the vertical datum.

Concentrations of chemical constituents in water are given either in milligrams per liter (mg/L) or micrograms per liter $(\mu \mathrm{g} / \mathrm{L})$.

Water year is defined in this report as the 12-month period October 1 through September 30, designated by the calendar year in which it ends. 


\section{Abbreviations Used in This Report}

$\begin{array}{ll}\mathrm{CaCO}_{3} & \text { calcium carbonate } \\ \mathrm{Ca} & \text { calcium } \\ \mathrm{Mg} & \text { magnesium } \\ \mathrm{Na} & \text { sodium } \\ \mathrm{K} & \text { potassium } \\ \mathrm{SO}_{4} & \text { sulfate } \\ \mathrm{Cl} & \text { chloride } \\ \mathrm{Si} & \text { silica } \\ \mathrm{N} & \text { nitrogen } \\ \mathrm{P} & \text { phosphorus } \\ \mathrm{C} & \text { carbon } \\ \mathrm{Al} & \text { aluminum } \\ \mathrm{As} & \text { arsenic } \\ \mathrm{Cd} & \text { cadmium } \\ \mathrm{Cu} & \text { copper } \\ \mathrm{Fe} & \text { iron } \\ \mathrm{Pb} & \text { lead } \\ \mathrm{Mn} & \text { manganese } \\ \mathrm{Hg} & \text { mercury } \\ \mathrm{Zn} & \text { zinc } \\ & \end{array}$

\section{Units of Measure}

$\begin{array}{ll}\mathrm{cm}-\mathrm{s} & \text { centimeter second } \\ \mu \mathrm{m} & \text { micrometers } \\ \mu \mathrm{g} / \mathrm{g} & \text { micrograms per gram }\end{array}$





\title{
Analysis of Postfire Hydrology, Water Quality, and Sediment Transport for Selected Streams in Areas of the 2002 Hayman and Hinman Fires, Colorado
}

\author{
By Michael R. Stevens
}

\section{Abstract}

The U.S. Geological Survey (USGS) began a 5-year study in 2003 that focused on postfire stream-water quality and postfire sediment load in streams within the Hayman and Hinman fire study areas. This study was done in cooperation with many Federal, State, and local entities, including Douglas County; the U.S. Environmental Protection Agency; the cities of Aurora, Northglenn, Thornton, and Westminster; the Colorado Department of Public Health and Environment; Colorado River Water Conservation District; Colorado Springs Utilities; Denver Water; Federal Emergency Management Agency; North Front Range Water Quality Planning Association; and Routt and Medicine Bow National Forests.

This report compares water quality of selected streams receiving runoff from unburned areas and burned areas using concentrations and loads, and trend analysis, from seasonal data (approximately April-November) collected 2003-2007 at the Hayman fire study area, and data collected from 1999-2000 (prefire) and 2003 (postfire) at the Hinman fire study area. The water-quality data collected during this study include onsite measurements of streamflow, specific conductance, and turbidity, laboratory-determined $\mathrm{pH}$, and concentrations of major ions, nutrients, organic carbon, trace elements, and suspended sediment. Postfire floods and effects on water quality of streams, lakes and reservoirs, drinking-water treatment, and the comparison of measured concentrations to applicable waterquality standards also are discussed.

Postfire hydrologic effects were exemplified by a damaging flood in the Hayman burn area that occurred on July 2006 after 2.2 in. of rain, which increased the flow in West Creek from 62 cubic feet per second $\left(\mathrm{ft}^{3} / \mathrm{s}\right)$ to $2,170 \mathrm{ft}^{3} / \mathrm{s}$ in about $45 \mathrm{~min}$, causing approximately $\$ 11$ million in damage to Colorado State Highway 67. In the Hinman burn area, despite a snow-water equivalent that was near the 1999 through 2009 average, high runoff and local flooding were produced in 2003 in the burned North Fork Elk River (snowmelt peak measured 1,180 ft3 3 s) and Lost Dog Creek (snowmelt peak measured $174 \mathrm{ft}^{3} / \mathrm{s}$ ) watersheds, which were about 50 percent and 38 percent larger, respectively, than the estimated 100-year recurrence flood. Peak streamflow data for the postburn 2003 period indicated that a smaller amount of snow-water equivalent produced about a 30 percent increase in the annual peak streamflow than was predicted by the relation of peakflow and snow-water equivalent for the available prefire years (1999-2002).

Streamflow and transport of water-quality constituents were substantially higher in the immediate (the first year after the fire) postburn conditions and remained higher for 5 years thereafter for the burned Hayman stream (Fourmile Creek) than in the unburned reference stream (Pine Creek). In streams of both the Hayman and Hinman fires, concentrations and loads of almost every water-quality constituent were higher (sometimes by orders of magnitude) in streams receiving postfire runoff than in unburned reference streams.

In the Hayman fire study area, dissolved nitrite plus nitrate and orthophosphorus concentrations were generally one order of magnitude or larger in the first year postfire runoff (2003) in a burned watershed (Fourmile Creek), than in stream samples collected from an unburned watershed (Pine Creek). Similarly, total nitrogen and total phosphorus stream concentrations were generally two or three orders of magnitude larger for Fourmile Creek in the first year of postfire runoff (2003) than stream concentrations in unburned Pine Creek.

Total organic carbon concentrations (TOC) during storms in Fourmile Creek were large, including a maximum concentration for the May 30, 2003, storm of 4,160 milligrams per liter (mg/L). Median TOC concentrations (2003-2007) in Fourmile Creek $(7.1 \mathrm{mg} / \mathrm{L})$ were larger than median concentrations in the unburned Pine Creek watershed $(3.1 \mathrm{mg} / \mathrm{L})$. Median dissolved organic carbon (DOC) concentrations (2003-2007) in Fourmile Creek (2.7 mg/L) were similar to those in the unburned Pine Creek watershed $(3.2 \mathrm{mg} / \mathrm{L})$. DOC concentrations were high in some storm runoff samples from Fourmile Creek, including three storms that had concentrations ranging from $10 \mathrm{mg} / \mathrm{L}$ to $30 \mathrm{mg} / \mathrm{L}$ in Fourmile Creek.

Stream concentrations in the burned Fourmile Creek watershed in the Hayman fire study area were tested using a LOWESS streamflow adjustment and seasonal Kendall trend test. Results indicated that downward trends (percent decrease per year over 5 years) were statistically significant (p-value $<0.10)$ for specific conductance $(-7.3)$, calcium $(-11.8)$, magnesium $(-8.82)$, potassium $(-10.9)$, total ammonia 
plus organic nitrogen $(-26.1)$, nitrite plus nitrate $(-17.4)$, total phosphorus $(-37.5)$, dissolved phosphorus $(-25.6)$, dissolved organic carbon (-8.9), total recoverable arsenic $(-31.0)$, dissolved copper $(-8.8)$, dissolved manganese $(-48.5)$, total recoverable manganese $(-30.5)$, and total recoverable mercury $(-30.6)$.

Suspended-sediment concentrations in samples from the Hayman fire study area ranged from 1 to $83 \mathrm{mg} / \mathrm{L}$ in Pine Creek and from 4 to $55,000 \mathrm{mg} / \mathrm{L}$ in Fourmile Creek. Comparison of paired instantaneous suspended-sediment concentration and load using the Wilcoxon signed-rank test, indicated larger values in the burned watershed ( $\mathrm{p}$-value $<0.10$ ). Seasonal Kendall trend testing of concentrations (LOWESS-adjusted for streamflow) and loads (not adjusted) for 5 years postfire (2003-2007) in the Hayman fire study area in the burned Fourmile Creek watershed indicated downward trends (percent decrease per year over 5 years) in suspended-sediment concentration $(-47.2)$ and load $(-44.5)$ that were statistically significant ( $p$-value $<0.10$ ), indicating a decrease in suspended-sediment concentration and load during the 5-year period.

Comparison of instantaneous nutrient concentrations of prefire and postfire data in the Hinman fire study area, using the Mann-Whitney rank-sum test, indicated postfire concentrations were larger in Lost Dog Creek (p-value $<0.10$ ) for total ammonia plus organic nitrogen, and dissolved nitrite, nitrite plus nitrate, ammonia, and total and dissolved phosphorus. Postfire nutrient concentrations during high streamflow were sometimes several times larger than the prefire concentrations.

Median DOC and TOC concentrations from Lost Dog Creek and North Fork Elk River were similar (within about $1 \mathrm{mg} / \mathrm{L}$ ) to concentrations from a local unburned reference stream (Mad Creek). Although higher concentrations of TOC were detected in the burned streams (maximum $35 \mathrm{mg} / \mathrm{L}$ ) than in the unburned stream (maximum $9.5 \mathrm{mg} / \mathrm{L}$ ) during high streamflow, April-November. These results may indicate that, in the snowmelt-dominated setting, postfire DOC concentrations may not increase or may be masked by dilution resulting from the increase in postfire streamflow.

Suspended-sediment concentrations in samples collected from Lost Dog Creek ranged from less than 1 to $10 \mathrm{mg} / \mathrm{L}$ in prefire samples (1999 and 2000) and from 3 to $565 \mathrm{mg} / \mathrm{L}$ in postfire samples (2003). Estimated seasonal (April-September) suspended-sediment loads during prefire (1999) and postfire (2003) conditions indicate that suspended-sediment loads (normalized to drainage area) for postfire conditions were about one order of magnitude larger than prefire loads in North Fork Elk River, and more than two orders of magnitude larger than prefire suspended-sediment loads in Lost Dog Creek.

Exceedances of Colorado water-quality standards in streams of both the Hayman and Hinman fire study areas only occurred for concentrations of five trace elements (not all trace-element exceedances occurred in every stream). Selected samples analyzed for total recoverable arsenic (fixed), dissolved copper (acute and chronic), total recoverable iron (chronic), dissolved manganese (acute, chronic, and fixed) and total recoverable mercury (chronic) exceeded Colorado aquatic-life standards.

\section{Introduction}

Water quality, water quantity, and population growth are general concerns to water suppliers, water-treatment plant operators, planners, and resource managers in the Western United States, including Colorado. Recent drought conditions and large wildfires in Colorado have elevated these concerns. In 2002, during a multiyear statewide drought that affected most of Colorado, several large fires occurred in the State. This study discusses two of these fires. First, the Hayman fire (about 35 miles (mi) southwest of Denver, Colo.) (fig. 1), the largest known fire in Colorado history, burned about 138,000 acres (Graham, 2003). Second, the Hinman fire (about 25 mi north of Steamboat Springs, Colo.), burned about 16,000 acres. Postfire issues concerning communities and water infrastructure, including the increased potential for postfire flooding, debris flows, sedimentation, and degradation of water supplies and water quality, are problematic and costly to mitigate.

The U.S. Geological Survey (USGS) began a 5-year study in 2003 that focused on postfire stream-water quality and postfire sediment load in streams within the Hayman and Hinman fire study areas. This study was done in cooperation with many Federal, State, and local entities including Douglas County; the U.S. Environmental Protection Agency; the cities of Aurora, Northglenn, Thornton, and Westminster; the Colorado Department of Public Health and Environment; Colorado River Water Conservation District; Colorado Springs Utilities; Denver Water; Federal Emergency Management Agency; North Front Range Water Quality Planning Association; and Routt and Medicine Bow National Forests.

Potential postfire conditions that affect water quality include increased erosion and runoff, increased concentrations of chemical constituents (major ions, trace elements, nutrients, and organic carbon), and suspended-sediment loads in surface water (Neary and others, 2008). Degraded water quality may negatively affect public water-supply sources (streams and reservoirs) and water-treatment plant operations, and may also affect aquatic life and limit recreational uses. Large volumes of sediment and debris transported from burned watersheds clog intakes and filters of drinking-water treatment plants and may be deposited in stream channels or reservoirs, which affects aquatic life and reservoir operations, and may limit reservoir longevity. Trace elements transported from burned watersheds may exceed the Colorado drinking-water or aquatic-life standards. In addition to trace elements mobilized in runoff, some trace elements such as mercury may be volatilized from burned biomass and transported by wind, rain, and snow to streams and reservoirs, where mercury methylation and bioaccumulation may occur. Nutrients transported from burned watersheds may cause algae growth (Minshall and others, 1989; and Planas and others, 2000), which, in excessive quantities, can lead to eutrophication in streams and reservoirs. As eutrophication occurs, dissolved oxygen decreases, which can lead to fish kills and the release of nutrients and trace elements from bottom sediments into 


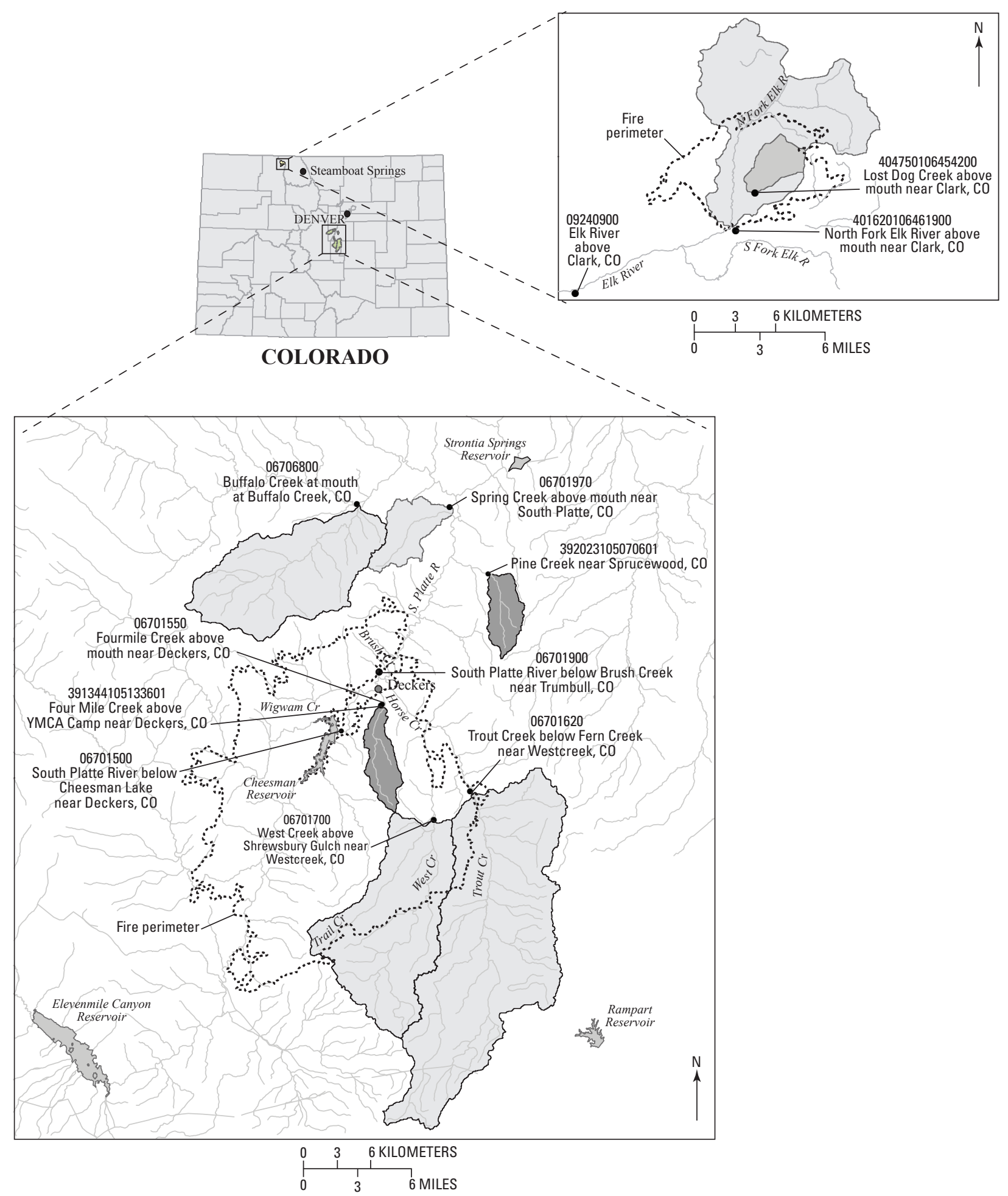

Figure 1. Map showing location of Colorado streams and sampling sites affected by the Hayman and Hinman fires. 
the overlying water column. Eutrophication may result in loss of recreation, property values, degradation of water supplies, and damage to ecosystem function (Dodds and others, 2009). Total organic carbon (TOC) or dissolved organic carbon (DOC) transported from burned watersheds is a concern for drinking-water treatment because chlorination may produce trihalomethanes, which are carcinogens (U.S. Environmental Protection Agency, 2002). The reaction of DOC with chlorine also may cause a high chlorine demand during drinking-water treatment, which may lead to ineffective disinfection and increased treatment costs. Other regulated and nonregulated organic compounds also may be produced by fire and may be present in postfire runoff that is transported to drinking-water reservoirs or water-treatment plants.

\section{Purpose and Scope}

The general purpose of this report is to compare and contrast the water quality of selected streams receiving runoff from burned areas affected by the Hayman and Hinman fires and adjacent unburned areas. Specific objectives of this report are to (1) conduct detailed analysis of the response of watersheds to fire by examining differences in concentrations and loads of nutrients, organic carbon, trace elements, and suspended sediment between streams receiving runoff from burned and unburned areas, and examine differences in watershed response between the two fire study areas with physiography and climate typical of two important regions in Colorado; (2) investigate recovery of stream-water quality to prefire conditions using trend analysis; (3) discuss potential effects of postfire runoff on streams, lakes, and drinking-water treatment; and (4) identify postfire water-quality constituents that may be a postfire concern to public health or aquatic biota.

The scope of the study characterizes water quality primarily in one stream receiving runoff from an area burned by the Hayman fire (Fourmile Creek) and one similar nearby stream (Pine Creek) receiving runoff from an area that was not burned by the Hayman fire (hereinafter referred to as the "Hayman fire paired-watershed study"). A few water-quality samples also were collected from the South Platte River below Brush Creek near Trumbull, which is downstream from Fourmile Creek but upstream from Pine Creek (fig. 1). Fourmile Creek, Pine Creek, and South Platte River below Brush Creek near Trumbull, are hereinafter be referred to as "Fourmile," "Pine," and "South Platte Trumbull," respectively. The Hayman fire paired-watershed study also considers the quality of stream water affected by spring snowmelt runoff, episodic runoff from summer storms, and stream-water quality during late summer and early fall, which is primarily base flow supplied by groundwater. In the Hayman fire paired-watershed study area, stream-water quality and suspended-sediment samples were collected and analyzed by the USGS from 2003 to 2007. (Descriptions of yearly context are considered "water years," defined in this report as the 12-month period October 1 through September 30, designated by the calendar year in which it ends. No further mention of the term "water year" is considered necessary for the remainder of the report.)

In the Hinman fire study area, prefire water-quality data collected by USGS from the North Fork Elk River and Lost Dog Creek (1999 to 2000) (Leib and von Guerard, 2003) were compared with postfire water-quality data collected in this study during 2003. Three miscellaneous high-flow samples also were collected at North Fork Elk River and Lost Dog Creek during snowmelt in 2006 to monitor the recovery of water quality.

The statistical significance of water-quality differences between streams receiving runoff from burned and unburned areas (spatial differences) was calculated. Trends in water quality through time (temporal trends) also were evaluated using trends analysis (Helsel and Hirsch, 1992).

Data collected during this study include onsite measurements of streamflow, specific conductance, and turbidity (field properties), and laboratory-determined values of $\mathrm{pH}$, and concentrations of major ions, nutrients, organic carbon, trace elements, and suspended sediment (table 1). In 2003, tentatively identified organic compounds (TICs) also were identified in water and bed-sediment samples collected from selected streams from burned areas of the Hayman and Hinman fires. Trace-element samples in bed sediment also were collected from selected streams in burned areas of the Hayman and Hinman fires.

Water quality of samples collected from the target streams affected by the Hayman fire and Hinman fire was compared to Colorado water-quality numeric standards and guidelines of the Colorado Department of Public Health and Environment (CDPHE) (Colorado Department of Public Health and Environment, 2008a, 2008b, and 2008c).

\section{Description of Study Areas}

The Hayman fire paired watersheds compared in this report are southwest of Denver (fig. 1), in the Colorado Front Range physiographic area, which is in the southern part of the Southern Rocky Mountains physiographic province (Fenneman, 1931; Fenneman and Johnson, 1946). The burned area ranges in elevation from about 6,500 to $10,000 \mathrm{ft}$ above the North American Vertical Datum of 1988 (NAVD 88) and affects a major source area for metropolitan Denver's raw water supply. The Hayman fire paired watersheds are at about $8,000 \mathrm{ft}$ in elevation (table 2) and are characterized by moderately steep slopes (U.S. Geological Survey, 2009) that are underlain by weathered Pikes Peak Granite (Tweto, 1979). Soils are thin, gravelly, and sandy loams developed on the weathered granite (grüs) and are classified as Typic Ustorthents and Typic Cryorthents (Moody and Martin, 2001a). The soils range from about 10 to 20 in. in depth and have high infiltration rates (Rhoades and others, 2006). The area is predominantly forested with ponderosa pine (Pinus ponderosa) and Douglas-fir (Pseudotsuga menziesii) with minor areas of riparian vegetation along the 
Table 1. Collection and analysis methods for water-quality properties and constituents.

[ICP, inductively coupled plasma; ICPMS, inductively coupled plasma mass spectrometry; IC, ion chromatography; CV-AFS, cold vapor-atomic fluorescence spectrometry; EWI, equal-width increment; MV, multiple vertical depth integrated; mg/L, milligrams per liter; $\mathrm{cm}^{-1}$, per centimeter; $\mathrm{ft}^{3} / \mathrm{s}$, cubic feet per second; $\mu \mathrm{S} / \mathrm{cm}$ at $25^{\circ} \mathrm{C}$, microsiemens per centimeter at $25^{\circ} \mathrm{C} ; \mu \mathrm{g} / \mathrm{L}$, micrograms per liter; NTU, nephelometric turbidity units; CaCO ${ }_{3}$, calcium carbonate; $\mathrm{nm}$, nanometers; $\mathrm{cm}$, centimeter; $\mathrm{t} / \mathrm{d}$, tons per day; $\mathrm{N}$, nitrogen; $\mathrm{P}$, phosphorus; $\mathrm{C}$, carbon; multiple values for reporting limits imply that the reporting limit from the laboratory has changed during the study, as these limits are subject to change depending on quality assurance information evaluated regularly by the U.S. Geological Survey National Water Quality Laboratory]

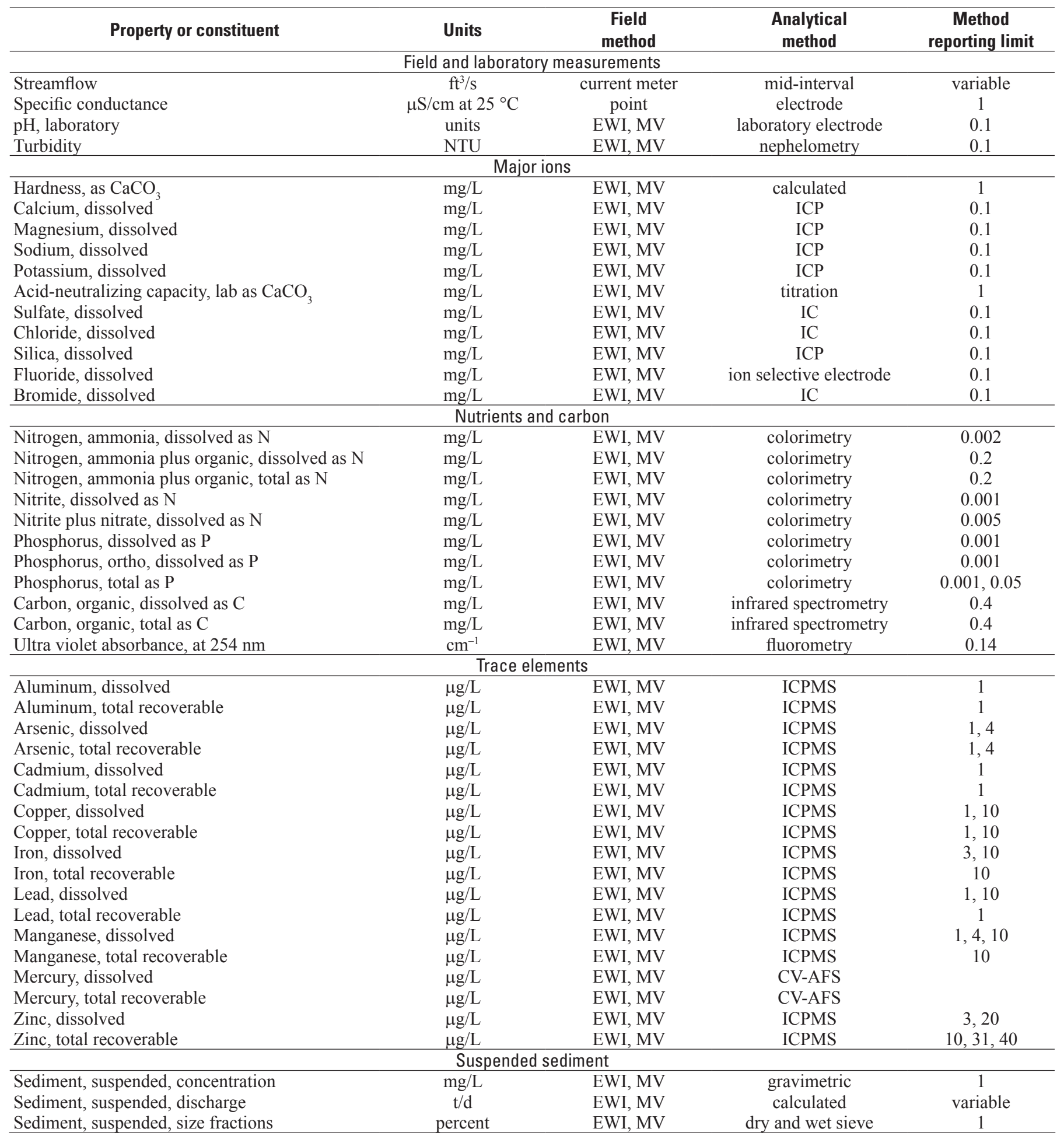


Table 2. Watershed characteristics for stream sites referenced in this report.

[Data are from U.S. Geological Survey, 2009; Burn severity data are from U.S. Department of Agriculture Forest Service, 2009; USGS station number on figure 1; f, continuous streamflow; i, instantaneous streamflow; p, precipitation; qw, water quality; s, suspended sediment; t, continuous turbidity; L, percentage low burn severity; M, percentage moderate burn severity; H, percentage high burn severity; -, no data; NAVD 88, North American Vertical Datum of 1988; stream gradient determined from geographic information system data]

\begin{tabular}{|c|c|c|c|c|c|c|c|c|c|c|c|c|c|c|}
\hline \multirow{2}{*}{$\begin{array}{l}\text { U.S. Geological } \\
\text { Survey } \\
\text { station number }\end{array}$} & \multirow{2}{*}{$\begin{array}{l}\text { U.S. Geological } \\
\text { Survey } \\
\text { station name }\end{array}$} & \multirow{2}{*}{$\begin{array}{l}\text { Data } \\
\text { type }\end{array}$} & \multirow{2}{*}{$\begin{array}{c}\text { Study } \\
\text { period } \\
\text { of record }\end{array}$} & \multirow{2}{*}{$\begin{array}{c}\text { Drainage } \\
\text { area } \\
\text { (square miles) }\end{array}$} & \multirow{2}{*}{$\begin{array}{c}\text { Mean } \\
\text { elevation } \\
\text { (feet, NAVD 88) }\end{array}$} & \multirow{2}{*}{$\begin{array}{l}\text { Stream } \\
\text { gradient } \\
\text { (ft/ft) }\end{array}$} & \multirow{2}{*}{$\begin{array}{l}\text { Percentage } \\
\text { slopes greater } \\
\text { than } 30 \text { percent }\end{array}$} & \multirow{2}{*}{$\begin{array}{l}\text { Mean annual } \\
\text { precipitation } \\
\text { (inches) }\end{array}$} & \multirow{2}{*}{$\begin{array}{l}\text { Percentage } \\
\text { forested }\end{array}$} & \multirow{2}{*}{$\begin{array}{l}\text { Name } \\
\text { of fire }\end{array}$} & \multirow{2}{*}{$\begin{array}{l}\text { Year } \\
\text { of fire }\end{array}$} & \multicolumn{3}{|c|}{$\begin{array}{l}\text { Burn severity } \\
\text { (percentage) }\end{array}$} \\
\hline & & & & & & & & & & & & L & M & H \\
\hline 06701550 & $\begin{array}{l}\text { Fourmile Creek above mouth } \\
\text { near Deckers }\end{array}$ & $f, i, p$ & 2003-2004 & 7.41 & 7,994 & - & 32 & 23 & 95 & Hayman & 2002 & - & - & - \\
\hline 391344105133601 & $\begin{array}{l}\text { Fourmile Creek above YMCA } \\
\text { Camp near Deckers }\end{array}$ & i, qw, s & 2003-2007 & 7.40 & 7,996 & 0.098 & 35 & 23 & 95 & Hayman & 2002 & 8 & 25 & 40 \\
\hline 392023105070601 & Pine Creek near Sprucewood & i, qw, s & 2003-2007 & 6.45 & 7,997 & 0.073 & 48 & 24 & 92 & Unburned & none & 0 & 0 & 0 \\
\hline 06701700 & $\begin{array}{l}\text { West Creek above Shrewsbury } \\
\text { Gulch near West Creek }\end{array}$ & $\mathrm{f}, \mathrm{i}, \mathrm{p}$ & 2003-2007 & 56.3 & 8,638 & - & 18 & 20 & 92 & Hayman & 2002 & 5 & 13 & 13 \\
\hline 06701620 & $\begin{array}{l}\text { Trout Creek below Fern Creek } \\
\text { near West Creek }\end{array}$ & $f, i, p$ & 2003-2007 & 106.0 & 8,635 & - & 24 & 23 & 79 & Hayman & 2002 & 1 & 1 & 1 \\
\hline 06701970 & $\begin{array}{l}\text { Spring Creek above mouth near } \\
\text { South Platte }\end{array}$ & $f, i, p$ & 2003 & 9.74 & 7,363 & - & 27 & 20 & 41 & $\begin{array}{l}\text { Buffalo } \\
\text { Creek }\end{array}$ & 1996 & - & - & - \\
\hline 06706800 & $\begin{array}{l}\text { Buffalo Creek at mouth at } \\
\text { Buffalo Creek }\end{array}$ & $f, i, p$ & 2003 & 47.6 & 8,374 & - & 43 & 26 & 80 & $\begin{array}{l}\text { Buffalo } \\
\text { Creek }\end{array}$ & 1996 & - & - & - \\
\hline 06701900 & $\begin{array}{l}\text { South Platte River below } \\
\text { Brush Creek near Trumbull }\end{array}$ & $\begin{array}{c}\mathrm{f}, \mathrm{i}, \mathrm{qw}, \\
\mathrm{s}, \mathrm{t}\end{array}$ & 2003-2007 & 767.0 & 8,811 & - & 27 & 21 & 75 & Hayman & 2002 & - & - & - \\
\hline 06701500 & $\begin{array}{l}\text { South Platte River below } \\
\text { Cheesman Lake near Deckers }\end{array}$ & $\mathrm{f}, \mathrm{i}$ & 2003-2007 & 499.0 & 9,028 & - & 29 & 20 & 68 & Hayman & 2002 & - & - & - \\
\hline 404620106461900 & $\begin{array}{l}\text { North Fork Elk River above } \\
\text { mouth near Clark }\end{array}$ & i, qw, s & $\begin{array}{l}\text { 1999-2000, } \\
2003\end{array}$ & 41.4 & 9,740 & 0.068 & 37 & 37 & 63 & Hinman & 2002 & 21 & 30 & 21 \\
\hline 404750106454200 & $\begin{array}{l}\text { Lost Dog Creek above mouth } \\
\text { near Clark }\end{array}$ & i, qw, s & $\begin{array}{l}\text { 1999-2000, } \\
2003\end{array}$ & 3.20 & 9,690 & 0.162 & 32 & 36 & 76 & Hinman & 2002 & 25 & 26 & 25 \\
\hline 09240900 & Elk River above Clark & $f, i$ & $\begin{array}{l}\text { 1999-2000, } \\
2003\end{array}$ & 122.0 & 9,530 & - & 34 & 43 & - & Hinman & 2002 & - & - & - \\
\hline
\end{tabular}


stream channels. It is mostly in the lower montane (about 6,000 to $8,000 \mathrm{ft}$ ) ecological zone with some upper montane $(8,000$ to $9,000 \mathrm{ft})$ and subalpine areas $(9,000$ to $11,500 \mathrm{ft})$ on some of the higher mountains (LeMaster and others, 2007). Fourmile, which drains a burned watershed, flows northward and is about 9 mi southwest from Pine, which drains an unburned watershed and generally flows north (fig. 1). The paired watersheds were selected for the study because they are similar in topography, slope, aspect, size, geology, and vegetation. The primary difference between the two watersheds is that Fourmile was burned, and Pine was not.

Precipitation in the area of the Hayman fire study occurs predominantly as rain during the warmer months of the year (May through September) and snow during the colder months (October through April). Storm activity can be intense and occur as frontal storms early in the season (April-May) and as monsoon-moisture-driven storms later in the season (July-August) (Doesken and others, 2003). Afternoon thunderstorms of short duration generally occur from May through September. Mean annual precipitation is about 23 in. in the Fourmile watershed (table 2), and 24 in. in the Pine watershed (U.S. Geological Survey, 2009).

The Hinman fire study area is north of Steamboat Springs, Colo. (fig. 1), within the southern Rocky Mountains physiographic province (Fenneman, 1931; Fenneman and Johnson, 1946). The Hinman fire study area is topographically higher and wetter than the Hayman fire study area. Vegetation is forests of mostly subalpine fir (Abies lasiocarpa), Engelmann spruce (Picea engelmannii), lodgepole pine (Pinus contorta), and aspen (Populus tremuloides) (Leib and von Guerard, 2003). Elevations range from 8,500 to $11,500 \mathrm{ft}$, and slopes are moderately steep (greater than 30 percent). The study area includes watersheds drained by the North Fork of the Elk River above mouth near Clark and the small tributary of Lost Dog Creek above mouth near Clark, which are hereinafter referred to as "North Fork Elk" and "Lost Dog." The watersheds are underlain primarily by Precambrian igneous and metamorphic rocks and minor amounts of Mesozoic sandstone, shale, and limestone including surficial deposits of Pleistocene glacial till (Tweto, 1979; Leib and von Guerard, 2003).

The soils in the Hinman fire study area are primarily derived from Precambrian crystalline rocks and glacial deposits, with rocky soils consisting of a thin organic horizon overlying sandy loam mineral soils (Rumbaitis del Rio, 2006) and are classified as Typic Cryochrepts and Typic Dystrochrepts. The mean annual precipitation in the study area is approximately $37 \mathrm{in}$. with most precipitation falling as snow (U.S. Geological Survey, 2009).

As part of an earlier study, the USGS collected waterquality data from North Fork Elk and Lost Dog in 1999 and 2000 (Leib and von Guerard, 2003), which comprise the preHinman fire water-quality data. Much of the Hinman fire study area contained fallen dead timber from the Routt blowdown (a severe windstorm on October 25, 1997, that blew down more than 20,000 acres of forest). Following the blowdown, spruce beetle infestations killed much of the remaining forest, which subsequently burned in the 2002 Hinman fire (Leib and von Guerard, 2003; Kulakowski and Veblen, 2007) (fig. 2). In the current study, the USGS collected and analyzed water samples collected from the North Fork Elk and Lost Dog in 2003.

Annual precipitation in the Hinman fire area is about 12 in. greater than precipitation in the Hayman area and falls primarily as snow during October through May. Locally intense thunderstorms of short duration occur in summer but usually cause only minor, short-duration rises in stream stage at these high elevations (Doesken and others, 2003). The average annual precipitation is about $37 \mathrm{in}$. in the North Fork Elk watershed (table 2), and 36 in. in the Lost Dog watershed (U.S. Geological Survey, 2009).

\section{Previous Investigations}

Research literature has documented increased wildfire hazards nationally (U.S. Geological Survey, 2006; Westerling and others, 2006) and has characterized increased postfire threats for flooding, debris flows, and sedimentation in the Western United States (Cannon and DeGraff, 2009). Elliott and others (2005) evaluated and mapped potential postfire hydrologic hazards including sediment-laden water floods and debris flows for three large Colorado fires (including the Hayman fire) that occurred in 2002. Elliott and others (2005) predicted expanded postfire inundation areas compared to prefire conditions because of changed watershed-runoff characteristics resulting from fire. Recent reports have characterized the potential for postfire debris flows to occur in the Western United States (Gartner and others, 2008; Cannon and others, 2010) and at specific sites in the headwaters of the Colorado River in Colorado (Stevens and others, 2008a; Stevens and others, 2008b).

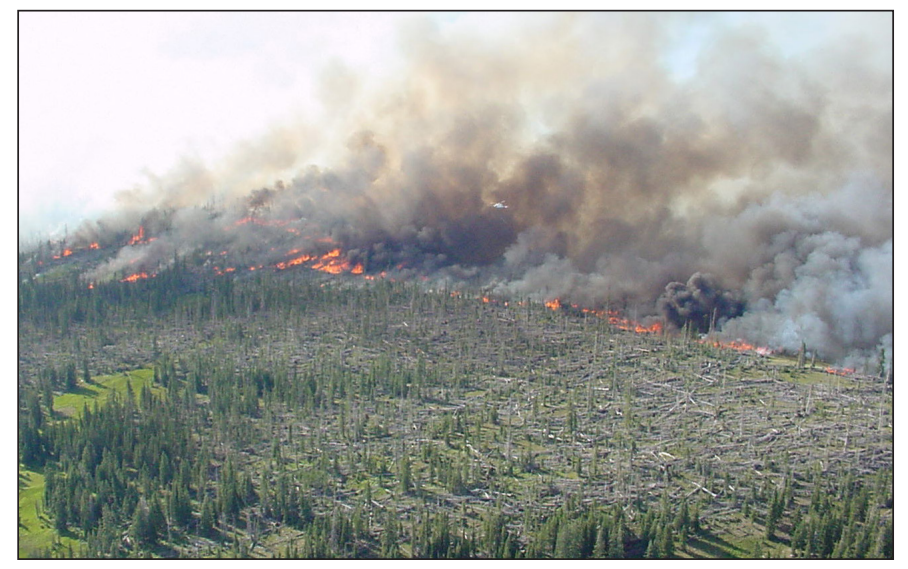

Figure 2. Photograph of the Mad Creek fire in 2001 burning as an intense surface fire in blowdown (similar to the blowdown consumed in the Hinman fire) in the upper Mad Creek watershed, which is located south of the Elk River watershed and has terrain similar to that of the North Fork of the Elk River Hinman fire study area (Northwest Colorado Fire Management Unit photograph, used with permission). 
A literature review concerning fire effects on the concentration of nutrients (nitrate and phosphorus) in surface water (Ranalli, 2004) indicated that nitrate concentrations and loads in fire-affected streams increase immediately during postfire storms and that maximum concentrations and loads occur within the first year or two after a wildfire. The U.S. Department of Agriculture (USDA) Forest Service, Rocky Mountain Research Station, published a report addressing the effects of fire on soils and water (Neary and others, 2008), which documents a summary of patterns of release for major ion, nutrient, and sediment constituents in postfire runoff. Mast and Clow (2008), in a four-year study of wildfire effects in Glacier National Park, reported that nitrate concentrations increased up to ten-fold above unburned reference stream concentrations during the first snowmelt season after fire, but growing season nitrate concentrations declined to background levels after two snowmelt seasons. In a Yellowstone National Park study, however, Brass and others (1996) noted that 5 years after a wildfire, mean nitrate concentrations remained 4 to 10 times greater in streams draining a burned watershed than in streams draining an unburned watershed. Mast and Clow (2008) reported that winter base-flow nitrate concentrations remained high throughout the 4-year study. Overall, elevated postfire phosphorus concentrations in watersheds seem to recover toward prefire concentrations generally within 1 to 2 years (Ranalli, 2004). The USGS recently published a report that evaluates postfire sediment yields in different rainfall regimes in the Western United States (Moody and Martin, 2009) and summarizes the large changes in sediment transport in burned watersheds. However, suspended-sediment concentrations were not affected substantially by fire in the Mast and Clow (2008) study. Hall and Lombardozzi (2008) provide a summary of a limited amount of additional water-quality data collected at several burned and unburned streams for a postfire macroinvertebrate study in the Hayman fire area.

\section{Methods}

The methods used to collect and process streamflow data, water-quality samples, and suspended-sediment samples collected from streams are described in this section.

\section{Data Collection}

Field properties (water temperature, specific conductance, and turbidity) and water-quality samples were collected simultaneously. Field properties were measured using meters calibrated with standards according to the manufacturer's instructions for each meter. Field methods used to measure instantaneous streamflow are described in Rantz and others (1982). Water-quality samples were collected following procedures outlined in the USGS National Field Manual
(U.S. Geological Survey, 2002), which documents USGS protocols for the collection of water-quality data. Equal-width increment sampling techniques were used when possible. However, smaller streams such as Fourmile and Pine were commonly too shallow for these techniques and for the use of isokinetic sampling equipment. When these conditions occurred, depth and width integrated samples were carefully collected at turbulent reaches or small waterfalls with small, open sample bottles.

In the Hayman fire paired-watershed study, water-quality and suspended-sediment samples were collected each year during the ice-free season (April-November) for 5 years (2003 through 2007). In the Hinman fire study area, waterquality and suspended-sediment samples were collected by the USGS (Leib and von Guerard, 2003) in 2 prefire years (1999 and 2000) and during this study in 2003, the year after the Hinman fire. For the Hayman fire paired-watershed study, streams were sampled each year during the spring snowmelt runoff (approximately April through May), during summer rainstorms (approximately May through August), and during periods characterized by low precipitation and dry conditions (approximately June through November). To characterize differences in stream-water quality associated with different hydrologic regimes, streams were sampled during snowmelt runoff, but sampling was sometimes problematic because of the variable snowpack and difficulties with predicting snowmelt. Storm-runoff samples were collected each year from Fourmile. Paired storm samples from Pine were not collected because storms affecting Fourmile did not affect Pine.

In the Hinman fire study area, postfire stream samples were collected during 2003 (with three additional samples in 2006), during high streamflows associated with spring runoff from snowmelt, and during moderate and low streamflows during summer and fall. No sampling was planned or attempted during rainfall runoff.

During this study, the USGS National Water Quality Laboratory (NWQL) in Denver, Colo., analyzed water samples and bed sediments using methods described in Brenton and Arnett (1993), Fishman and Friedman, (1989), Fishman (1993), Garbarino and Damrau (2001), Garbarino and others (2006), Garbarino and Struzeski (1998), O’Dell and others (1993), and Patton and Truitt (2000). The USGS Iowa Sediment Laboratory in Iowa City, Iowa, analyzed suspendedsediment samples using methods described in Guy (1969). The results of all laboratory analyses obtained during this study, except gas chromatograph-mass spectrometer (GC-MS) "tentatively identified compounds (TICs)" and trihalomethane (THM) results, reside in the USGS National Water Information System (NWIS, http://waterdata.usgs.gov/nwis) database. The analytical methods used to determine the potential for THMs to form can be found in Crepeau and others (2004) and were analyzed on filtered samples using chlorine dosing and purge-and-trap gas chromatography. Table 1 lists the analytes, analytical methods, and method-reporting limits (MRLs) for 
the samples collected for this study. Stream-water-quality and suspended-sediment data are presented in appendix 1 and statistics in appendix 2.

Results referred to as "dissolved" pertain to water that has been passed through a 0.45 -micrometer filter. All analytes in the text are considered dissolved unless otherwise indicated. Results referred to as "total" were determined using unfiltered, undigested samples. Results identified as "total recoverable" are from unfiltered water subjected to an in-bottle digestion procedure for trace elements (Hoffman and others, 1996). Table 1 lists the MRL that specifies the concentration below which values are reported as "less than," which is sometimes referred to as "censored" data (Helsel, 2005). Laboratory quantifications of concentrations below the MRL are sometimes provided and are typically qualified as estimates. The laboratory commonly can make only tentative identifications of organic compounds in water and bed sediment, which are referred to as TICs (appendix 3 and 4). Generally, these GC-MS scans are not calibrated to specific compounds but instead use a limited number of spiked laboratory compounds for a general calibration. Using this method, compounds are accurately identified, but concentrations are not precisely known and are considered estimated. Total-recoverable-mercury concentrations were normalized to suspended-sediment concentrations for part of the report discussion by dividing the mercury concentration by the suspended-sediment concentration so that the mercury (mostly in the particulate fraction) could be related to bulk soil concentrations of mercury.

\section{Data Analysis and Statistics}

Spatial and temporal analysis of water-quality concentrations and loads was done using nonparametric statistical techniques. The spatial analysis was done using the Wilcoxon signed-rank test (Helsel and Hirsch, 1992) to compare the water-quality results of paired samples (samples collected on the same day) from Fourmile fire study area with results from Pine for the Hayman fire study area. The Wilcoxon signedrank comparison also was used on the prefire and postfire data for North Fork Elk and Lost Dog in the Hinman fire study area.

Temporal trend analysis of water-quality data was done for the Fourmile and Pine multiyear data sets by using the seasonal Kendall test to assess monotonic trends (Helsel and Hirsch, 1992). The seasonal Kendall test is a nonparametric trend test that computes the Mann-Kendall statistic on data from similar seasons, which reduces the effect that seasonal patterns may have on trend detection (Helsel and Hirsch, 1992). In this study, six periods were defined for the seasonal Kendall test as follows: March-April, May, June, July-August, September, and October-December.

Trend tests were evaluated with two-tailed statistical procedures. The probability of error ( $p$-value) was used in this report to determine the significance of statistical tests for all statistical methods. Statistical results having p-values less than 0.10 were defined in this report as significant. The use of the word "significant" only applies to the p-value of the statistical test.

Adjustments of water-quality concentrations to account for variation due to changes in streamflow also were used to improve the statistical power of the temporal trend tests. Adjusted concentrations are transformed residuals (such as a natural log-linear transform) from a regression of the trend variable of interest and streamflow (Helsel and Hirsch, 1992). In this study, LOWESS regression (LOcally WEighted Scatterplot Smooth) (Cleveland and McGill, 1984, 1985) was used for the streamflow adjustment of concentrations (not loads) following methods described in Helsel and Hirsch (1992). These methods are commonly used to remove the effects of streamflow from water-quality concentration. For example, in a suspended-sediment concentration, time-series dataset, it may be misleading to assess the trend in suspendedsediment concentration that is not adjusted for streamflow, because suspended-sediment concentration commonly changes proportionally with streamflow (a result of increased channel scour or increases in sediment-source runoff during higher streamflows). In this study, the LOWESS adjustment for streamflow was made to concentrations only. Loads are already streamflow-weighted and no LOWESS streamflow adjustments were made to load data.

All constituent loads (loads) or streamflow-weighted measurements in streams were calculated using streamflow and either water-quality or suspended-sediment concentrations or measurement units computed as follows (Crowfoot and others, 2004):

$$
\begin{aligned}
& \text { Load }(\text { tons } / \text { day })=\left[\text { instantaneous streamflow }\left(\mathrm{ft}^{3} / \mathrm{s}\right)\right. \\
& \times \text { constituent concentration }(\mathrm{mg} / \mathrm{L})] \times 0.0027
\end{aligned}
$$

$$
\begin{aligned}
& \text { Streamflow-weighted measurement (such as turbidity } \\
& \quad[\text { nephelometric turbidity units }\{\mathrm{NTU}\}] \text { : } \\
& \text { NTU- } \left.\mathrm{ft}^{3} / \mathrm{s}\right) \text { or }\left(\text { specific conductance: } \mu \mathrm{S}-\mathrm{ft}^{3} / \mathrm{cm}-\mathrm{s}\right) \\
& =\text { measurement value } \times \text { instantaneous streamflow }\left(\mathrm{ft}^{3} / \mathrm{s}\right)
\end{aligned}
$$

The load or mass of constituents transported in streams over a period helps to interpret the potential effects on downstream receiving waters (other streams, lakes, or reservoirs). Seasonal loads were computed for suspended sediment, total phosphorus, orthophosphorus, total nitrogen, nitrite plus nitrate, total organic carbon, potassium, total recoverable manganese, and total recoverable mercury. The first full postfire runoff year (April through September 2003) was used for seasonal load computations for Fourmile, Pine, and the South Platte near Trumbull. April through September loads were computed for North Fork Elk and Lost Dog, utilizing 1999 data as the prefire runoff year and 2003 data as the first entire postfire runoff year for the Hinman fire of 2002 . 
Loads were calculated using the daily streamflow from a gaging station (Fourmile) or estimated daily values (Pine, North Fork Elk, and Lost Dog). Streamflow at Pine for 2003 was estimated using the instantaneous streamflow measurements and hydrograph comparison with Trout Creek (a nearby gaged stream with a watershed that was only slightly affected, about 5 percent medium and high burn severity, by the Hayman fire) (fig. 1). Daily mean streamflows at North Fork Elk and Lost Dog were estimated by using instantaneous streamflow measurements and hydrographic comparisons from the streamflow record at the Elk River above Clark gaging station. These hydrographic comparisons are subject to large uncertainties (Parrett and Johnson, 1994). Regressions also are used in the report to describe relations among selected constituents at Lost Dog and to select constituents for inclusion in the seasonal loads computations in the report. The coefficient of determination $\left(\mathrm{r}^{2}\right)$ is used as a measure of fit for the regression equations and is defined as the fraction of the data variation explained by the regression equation (Helsel and Hirsch, 1992).

Boxplots (Helsel and Hirsch, 1992) were made for concentration and load data at all sites. The data from each site is displayed side-by-side for selected water-quality measurements and constituents. The upper horizontal line of the box is the 75th percentile or upper quartile ( 75 percent of the data are less than this value). The horizontal line within the box represents the median value (50 percent of the data are greater than this value and 50 percent of the data are less than this value). The lower horizontal line of the box is the 25 th percentile or lower quartile ( 25 percent of the data are less than this value). The interquartile range (IQR) contains the values between the 25 th and 75 th percentiles and is the difference between the 25 th and 75 th percentiles. The bottom of the vertical line on the boxplot is the smallest value within 1.5 times the IQR of the box. The top of the vertical line on the boxplot is the largest value within 1.5 times the IQR of the box. Outside values are greater than 1.5 times the IQR from the box and outlier values are greater than 3 times the IQR from the box (Helsel and Hirsch, 1992).

Regressions of instantaneous streamflow and instantaneous water-quality constituent loads were computed. When log-linear transformations were used, correction for transformation bias was added to the regression equation (Duan, 1983). The data were not adequate to compute separate regressions for different hydrograph periods (rising limb, falling limb, and base flow), so data for the entire runoff season (April through September) were used to compute the regressions. Storm samples at Fourmile and South Platte Trumbull were generally excluded from the regressions because of lack of correlation with nonstorm samples, which make up the bulk of daily streamflow values. The exclusion may tend to bias some loads toward low values, but because of the brevity of storm-related streamflow events, most of the total load seemed to come from nonstorm streamflows. Some loads for the South Platte Trumbull were computed using regressions of turbidity (daily mean turbidity from instream continuous monitor) and instantaneous water-quality constituent loads.

The uncertainties for the load regressions and the uncertainty in streamflow estimates may be large but are not believed by the author to be large enough to overcome the substantial differences in concentration and high-streamflow response between the burned and unburned watersheds. Therefore, this report assumes that the methods used provide estimates that are adequate for load comparisons between prefire and postfire conditions at the Hayman and Hinman study areas.

\section{Quality Assurance}

This section describes the quality assurance and quality control (QA/QC) protocols used in this study and the interpretation of the QA/QC data collected during the study. Approximately 10 percent of the total samples collected during this study were for QA/QC (blanks and replicates). Inconsistencies or the existence of error indicated by quality assurance techniques can undermine confidence in the data and the interpretations that are made with that data.

\section{Laboratory Quality Assurance}

The USGS NWQL routinely follows established QA/QC protocols (Maloney, 2005). All water-quality samples were analyzed at the NWQL except suspendedsediment concentrations, which are subject to QA/QC protocols at the USGS Iowa Sediment Laboratory (Fishman and Friedman, 1989). The analytical results provided by NWQL were reviewed for inconsistencies, such as dissolved results greater than total or total recoverable results and data outliers. A small proportion of dissolved results were greater than total or total recoverable results for low concentrations of ammonia plus organic nitrogen, organic carbon, and some trace elements; and orthophosphorus was sometimes larger than dissolved phosphorus at low concentrations, but no substantial or systematic bias was observed. For example, on August 31, 2007, at Fourmile Creek, dissolved organic carbon was $2.7 \mathrm{mg} / \mathrm{L}$ and total organic carbon was $2.4 \mathrm{mg} / \mathrm{L}$. Although this is not representative of the true relation in the stream, it was likely related to the precision of the analysis method used at these low concentrations. Also, because the two bottles used for this analysis do not analyze the same exact water (mixing issues), this type of error is explainable and acceptable. Outliers were common in the concentrations analyzed from burned watersheds but were explained by the extreme effects of fire, the effects of storm runoff, and the ongoing processes of watershed recovery that allow for few stable comparisons through time. For example, on August 26, 2003, the concentration of total recoverable iron in North Fork Elk Creek was $485 \mu \mathrm{g} / \mathrm{L}$, which was about 4 times higher 
than other low-flow samples that season. The outlier can be explained, because it was noted that this visit was during the hydrograph recession from an afternoon thundershower. If no explanation was found and was accompanied by additional evidence that a sample or laboratory error could be at fault, the result might be discarded from the dataset. Milliequivalent balances for major ions (cations and anions) were calculated according to methods described by Hem (1985). Typically, the major ions are the principal contributors of electrical charge for dissolved constituents in water, and their sum should be close to zero. Departures from zero may indicate inaccurate major-ion analyses. In this study, 90 percent of samples with sufficient data had major-ion balances of less than 9 percent (median of 4 percent), indicating generally good major-ion analytical results from the NWQL. For Fourmile and perhaps other sample sites, the general lack of fluoride data for the ion balance calculation is at least part of the cause of higher deviation of ion balances in samples. For example, for one sample that was analyzed for fluoride, the addition of a fluoride result to the ion balance changes the difference in major-ion balance from 7.4 percent to 1.8 percent. Because ion balance is usually only related to major-ions analyses, which are a minor part of the report results, the ion balances have no effect on conclusions about nutrients, carbon, trace elements, or suspended sediment.

\section{Field Quality Assurance}

Sequential replicate samples (replicates) and field blank samples were collected in the field for quality-assurance purposes. Replicates were collected and analyzed to determine sampling and analytical precision. Sequential replicates were collected immediately after an environmental sample was collected. Field blank samples also were collected to determine if contamination introduced during field sampling and by equipment used to sample or process samples biased any results. Field blanks were prepared by using NWQLcertified inorganic and organic blank water that was passed through the sampling equipment and filter, then processed and analyzed as a regular environmental sample.

The relative percent difference (RPD) was computed for replicate samples (appendix 5). The RPD for the environmental and replicate sample values was calculated according to the following equation as described in Bossong and others (2006):

$$
\mathrm{RPD}=\{(a-b) /[(a+b) / 2]\} \times 100
$$

where

$$
\begin{aligned}
& \text { is the constituent concentration in the } \\
& \text { environmental sample, and } \\
& \text { is the constituent concentration in the } \\
& \text { replicate sample. }
\end{aligned}
$$

The replicate data indicated generally reproducible analytical results. Median RPDs ranged from 0 to 29 percent. Many of the larger RPDs were due to concentrations or values near the MRL. In these cases, concentrations may have differed little but result in large RPDs. For example, a sample with a concentration of $0.01 \mathrm{mg} / \mathrm{L}$ and a replicate concentration of $0.02 \mathrm{mg} / \mathrm{L}$ would result in an RPD of 67 percent. High RPD increases the variability and uncertainty of analytical results. Large uncertainty can decrease the significance of statistical differences and statistical trend tests.

The laboratory results from field blank samples (appendix 6) indicated no substantial contributions to sample concentrations from ambient site conditions or inadequate decontamination of sampling equipment. Median and maximum values or concentrations in field blanks indicated no substantial or systematic contamination bias during collection and processing of samples.

\section{Hydrology}

The hydrology of burned watersheds is important because the potential for postfire hydrologic hazards such as floods and debris flows often increases substantially in comparison to unburned watersheds. Postfire hydrology may affect the source, flow path, and transport of water, rock, and sediment, including partly burned vegetation. Fire may consume the forest canopy, understory vegetation, and forest-floor litter that normally intercept rainfall, and fire may reduce the water infiltration capacity of soil by increasing the water repellency (hydrophobicity) of the soil. Causes of water repellency can include soil sealing by fine particles or formation of an organic chemical layer below the soil surface (Larsen and others, 2009; DeBano, 2000). These factors increase the probability of overland runoff, which is not common in unburned forested hillslope environments (Ward and Elliot, 1995), and therefore can lead to the concentration of runoff and erosion of hillslopes and channels. Thus, postfire conditions combined with intense rainfall or a large or rapidly melting snowpack also can substantially increase the potential for floods.

\section{Hydrologic Setting}

\section{Hayman Fire Study Area}

All of the tributary streams in the Hayman fire study area flow to the South Platte River. Minor perennial tributaries downstream from Cheesman Lake (also known as Cheesman Reservoir) and within the general Hayman fire perimeter include Fourmile, West, Trout, Horse, and Brush Creeks; Pine is outside the fire perimeter (fig. 1) (table 2). Many of the smaller watersheds (less than a few square miles) in the area are drained by either intermittent or ephemeral streams. However, the Hayman fire may have changed watershed hydrology such that additional surface flow was present or large amounts of unconsolidated sediments were aggraded 
to the channel cross section, causing some surface flows to become subsurface flows. The tributary streams, like Fourmile (gradient 0.098, determined using geographic information system data) and Pine (gradient 0.073 ), generally receive variable amounts of snowpack each year. Minor amounts of snowmelt runoff occurred during warm periods in the late winter and spring in the Fourmile watershed (probably an effect that was exacerbated by the lack of shading from the loss of forest canopy), which complicated predicting the timing and magnitude of high streamflows and determining the snowmelt contribution to streamflow during this study.

In the general area of the Hayman fire, summer thunderstorms can be frequent, and large storms contribute substantially to short-term peak runoff in the burned watersheds. Substantial rainfall-runoff response was not observed from the unburned Pine watershed. The response from the unburned Pine watershed probably involved a more muted and lengthy peakflow response from subsurface interflow resulting from canopy and surface detention of rainfall, and high-infiltration rates of soils developed on Pikes Peak Granite. Without a continuous-streamflow gage to measure streamflow, the rainfall-runoff response could not be documented; however, no high-water marks were observed to indicate substantial peak streamflows. Streamflow is perennial through the dry summer and early fall months in streams such as Fourmile, Pine, and West Creek because of base flow from groundwater. In contrast, the much larger South Platte River within the study area flows through canyons with steep hillslopes and cliffs and is sustained primarily by snowmelt from high-mountain headwaters, releases from upstream reservoirs, and by local runoff from thunderstorms. Runoff from thunderstorms is a relatively minor component for the river because of the large streamflow contributions from reservoirs upstream from the Hayman fire study area.

\section{Hinman Fire Study Area}

Lost Dog is a small tributary (gradient 0.162 ) (table 2) of the North Fork Elk (U.S. Geological Survey, 2009) (fig. 1). Tributary streams, such as Lost Dog, that are affected by the Hinman fire drain to the North Fork Elk are generally higher in elevation and have steeper gradients than those in the Hayman fire study area. The North Fork Elk (gradient 0.068, 63 percent forested, with much area above timberline) is a large watershed (table 2) tributary to the main-stem Elk River, which drains to the Yampa River watershed within the Colorado River system. Typical for the Colorado mountains, snowmelt from April through August is the primary source of streamflow for both Lost Dog and North Fork Elk. Contributions to streamflow from rainstorms are typically minor. No reservoirs occur within the North Fork Elk watershed, although small natural lakes are present in the headwaters. Base flow from groundwater sustains streamflow through the relatively dry summer and fall months. Streams affected by the Hinman fire may exhibit increased snowfall capture or reduced infiltration (increased peak flows) and early snowmelt (because of less shade) (Brooks and others, 2003; Helvey, 1973; Campbell and Morris, 1988).

\section{Precipitation}

The amount and form of precipitation is one of the major differences between the Hayman and Hinman fire study areas. The precipitation hydrology of each study area is described in the following sections.

\section{Hayman Fire Study Area}

Long-term precipitation in the Hayman fire study area can be represented by the Cheesman National Oceanic Atmospheric Administration (NOAA) weather station (station id: 051528 , latitude: 39.2202 degrees, longitude: -105.2783 degrees, elevation: 2,097 meters) located at Cheesman Lake (fig. 1), which has complete records from 1948 to 2007 (Western Regional Climate Center, 2009). Following the 2002 drought, precipitation during 2003 was still less than the 58-year average precipitation (1948-2006) at the Cheesman weather station, but was near average during 2004-2006, and greater than average during 2007 (fig. 3). May, July, and August have the three highest monthly precipitation totals because of convective storms and monsoon moisture (fig. 4). The years 2003, 2005, and 2007 received snowfall above the 1948-2006 average (fig. 3). Snow is a substantial part of total precipitation from October through April, and March has the highest average snowfall (fig. 4). The probability of precipitation on any given day at the Cheesman weather station is approximately 23 percent; approximately 2 percent of daily total precipitation was larger than $0.5 \mathrm{in}$. based on data (1948-2006) from the Cheesman precipitation gage (Western Regional Climate Center, 2009).

Severe storms can produce high-intensity rainfall. For example, on May 30, 2003, an estimated 1.0 to 1.5 in. of rain fell in about $60 \mathrm{~min}$ over approximately one-half of the 7.4-square mile $\left(\mathrm{mi}^{2}\right)$ Fourmile Creek watershed (Robert Jarrett, U.S. Geological Survey, written commun., 2004; Brian Rappolt, Genesis Weather, written commun., 2004) (fig. 5). Another intense storm occurred on July 7, 2006 (fig. 6), in the watersheds of West, Trail, and Trout Creeks and produced a damaging flood along West Creek and Horse Creek (Colorado Department of Transportation, 2006). Most of the floodflows originated in the Trail Creek and upper West Creek (above Trail Creek) watersheds. This flood resulted from 2.2 in. of rain in about $2 \mathrm{~h}$ recorded at the West Creek streamgage (fig. 1) with a maximum 30-min intensity of $3.1 \mathrm{in} / \mathrm{h}(79 \mathrm{~mm} / \mathrm{h})$. Total rainfall in the Trail Creek watershed was unknown. Flooding from these storms will be described in the "Streamflow" section of this report. 


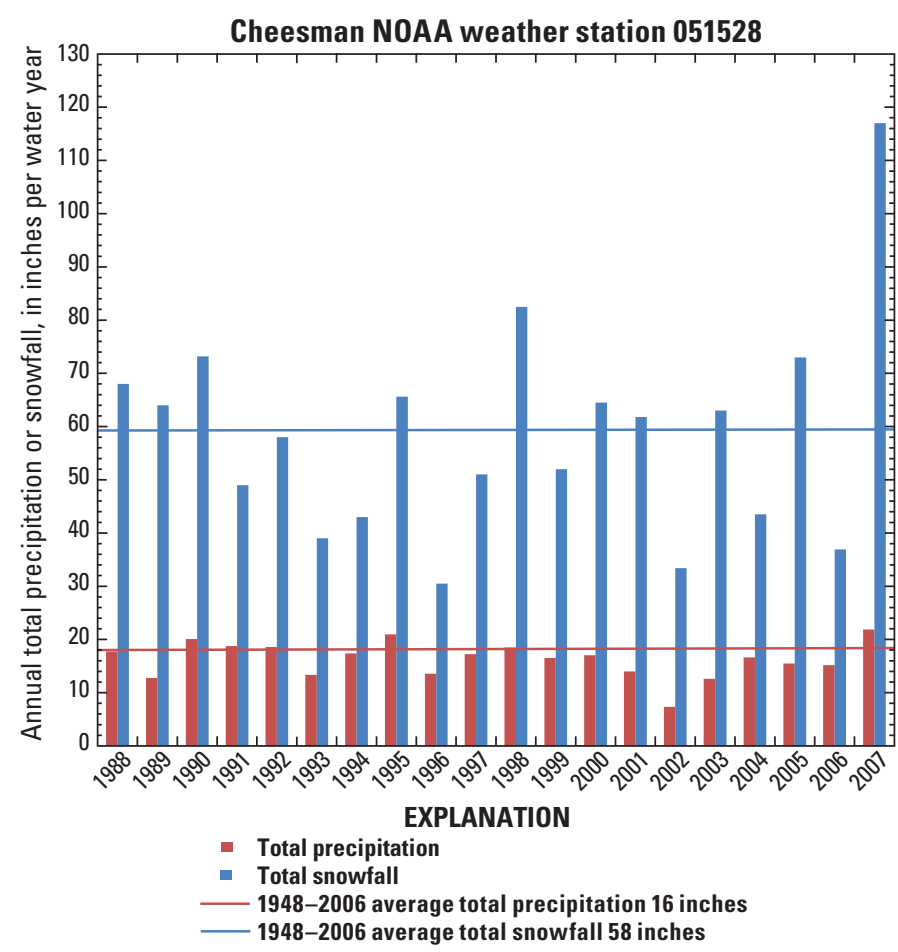

Figure 3. Graph showing a 20-year time-series (1988-2007) of annual snowfall and annual total precipitation for the National Oceanic and Atmospheric Administration (NOAA) Cheesman weather station (Western Regional Climate Center, 2009).

\section{Hinman Fire Study Area}

Long-term precipitation in the Hinman area is represented by the Lost Dog SNOwpack TELemetry (SNOTEL) weather station (latitude 40.8617 degrees, longitude - 106.7500 degrees) operated by the USDA Natural Resources Conservation Service (NRCS). Complete records were available for 1999 to 2009 (fig. 7). Following below-average precipitation in 2001 and 2002, 2003 precipitation was near the 11-year average precipitation at Lost Dog. The months with the highest monthly precipitation totals were November through February, and convective storms during the June through August summer months did not contribute much to the total annual precipitation (fig. 8). Most of the total precipitation from September through May was snowfall; December and January had the highest average precipitation (snowfall). Net snowpack accumulation, indicated by the rise in snow-water equivalent, continued throughout the winter until mid-April for the 1999 through 2009 average (fig. 9). In 2003, snow continued to accumulate until mid-May at the Lost Dog site, and then quickly melted, exacerbating runoff peaks in area streams. In general, snowmelt was complete at the Lost Dog site by early June. The probability of precipitation on a given day is approximately 40 percent, and approximately 5 percent of daily total precipitation was larger than $0.5 \mathrm{in}$. At higher elevations such as the North Fork Elk, rainfall generally does not produce the greatest threat of flooding except during postfire conditions. However, large snowpacks may cause flooding if the snowmelt occurs quickly or if snowmelt is accompanied by rainfall.

\section{Streamflow}

Instantaneous streamflows were measured when waterquality samples were collected at sites in the Hayman and Hinman fire study areas. A continuous streamflow-gaging station at Fourmile was available for analysis. For this report, the results are described in separate sections as nonflood and flood flows.

\section{Hayman Fire Study Area}

\section{Nonflood Flows}

Although the Hayman fire study area does not receive the large snowfalls typical of the western side of the Continental Divide, snowmelt is sometimes an important contributor to streamflow. In the Fourmile and Pine watersheds, in 2003 through 2007, instantaneous streamflow measurements indicated that streamflows were generally high most years in March through May (fig. 10), which corresponded to the snowmelt period. In some years, however, the highest instantaneous streamflows were probably caused by rainfall runoff, as they were in May 2003 at Fourmile. Partial snowmelt on warm winter and spring days commonly precedes the main snowmelt pulse during March through May, and tends to reduce the amount of snow available to melt during the main snowmelt period.

Instantaneous streamflows were measured when waterquality samples were collected. Although median streamflows were 3 times larger at Fourmile $\left(1.82 \mathrm{ft}^{3} / \mathrm{s}\right)$ than Pine $\left(0.60 \mathrm{ft}^{3} / \mathrm{s}\right)$ during 2003 through 2007, no statistically significant differences in paired instantaneous streamflows (normalized to drainage area) were indicated by the Wilcoxon signed-rank test

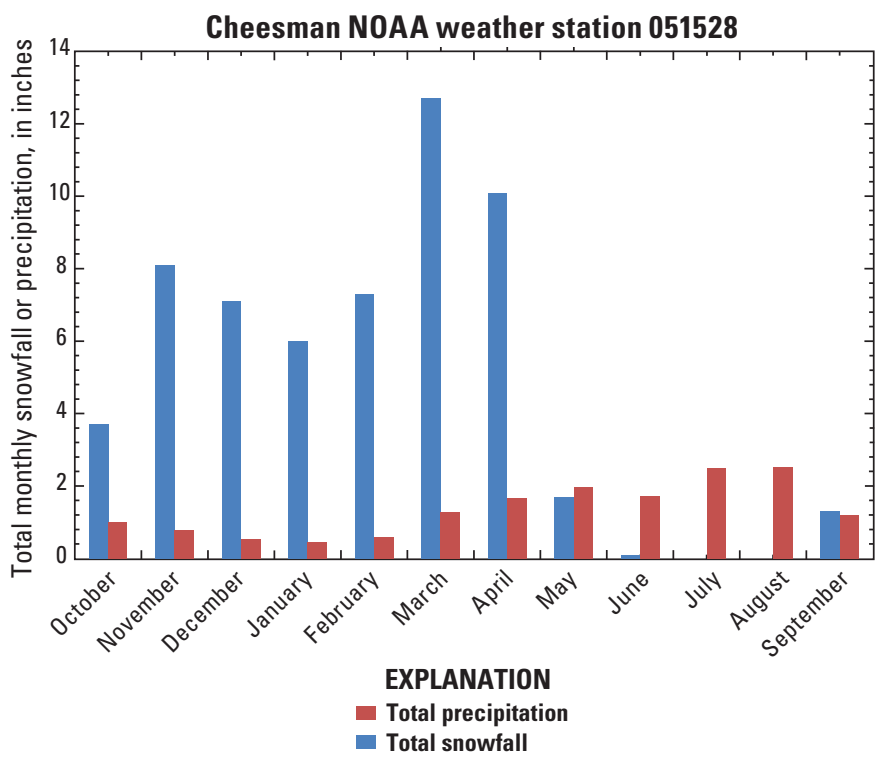

Figure 4. Graph showing mean monthly snowfall and total precipitation for the National Oceanic and Atmospheric Administration (NOAA) Cheesman weather station, 1948 through 2006 (Western Regional Climate Center, 2009). 


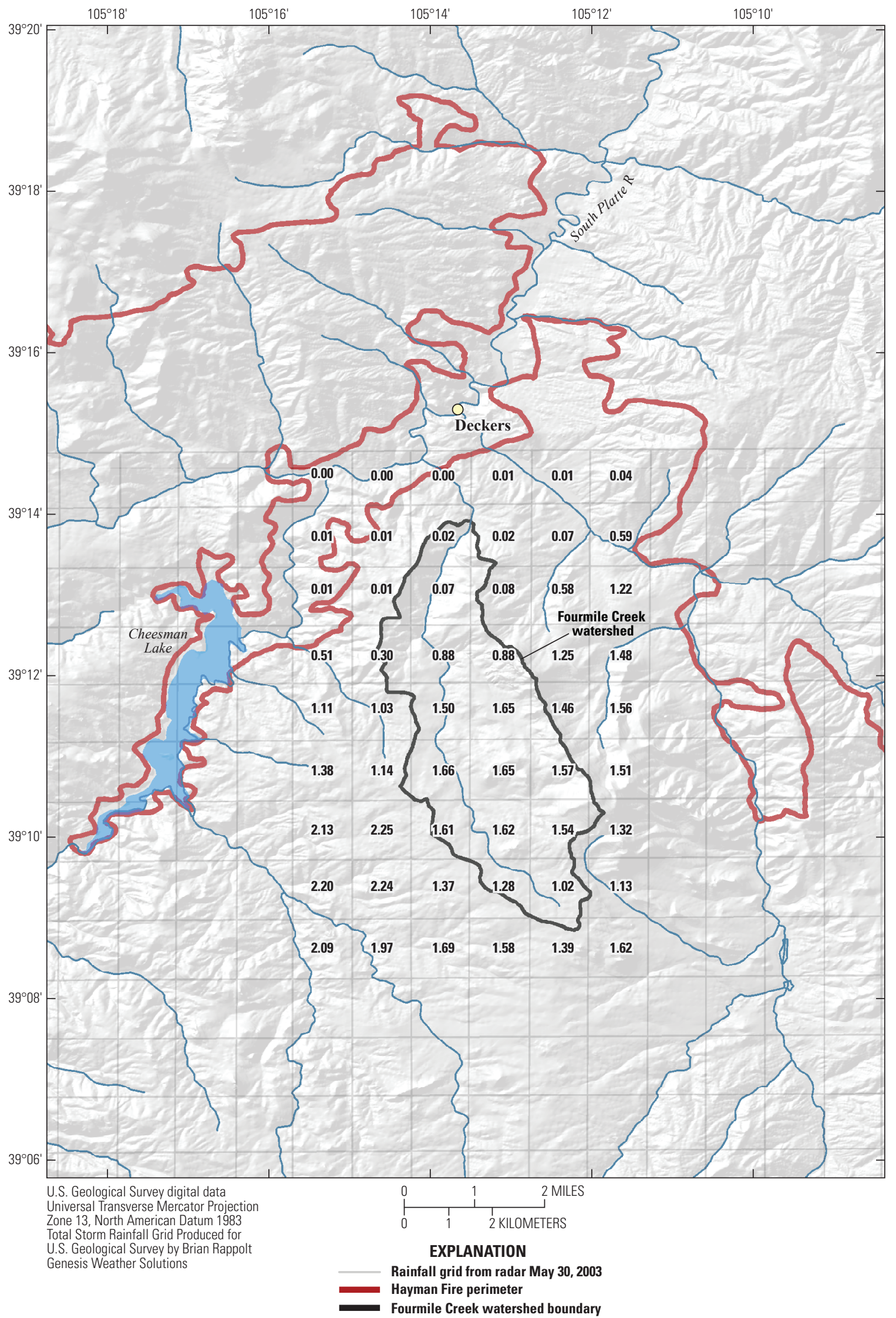

Figure 5. Map showing estimated rainfall distribution, in inches, based on Doppler radar data and precipitation gages for May 30, 2003, storm over Hayman burn area (Brian Rappolt, Genesis Weather, written commun., 2004). 


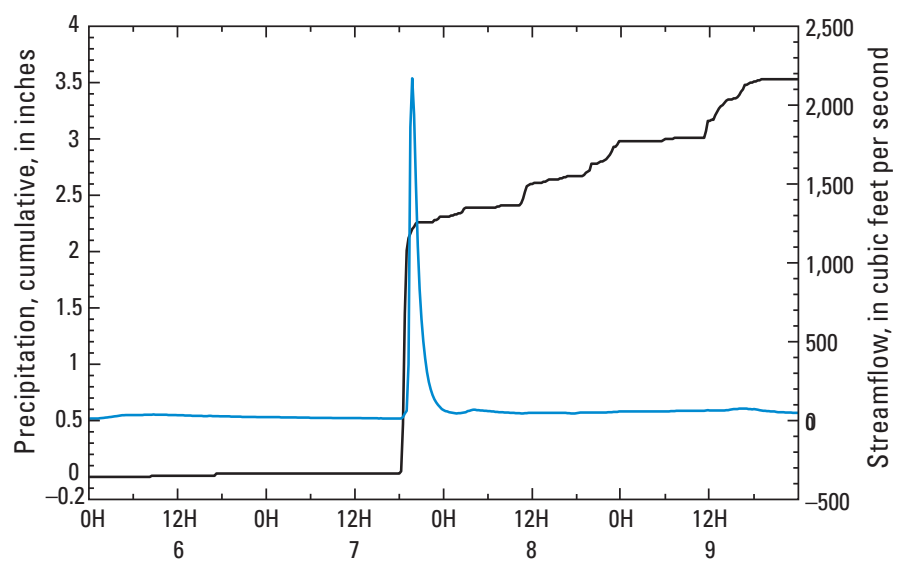

July, 2006

EXPLANATION

- Precipitation (15-minute data)

Streamflow (15-minute data)

Figure 6. Graph showing cumulative precipitation and streamflow at the West Creek streamgage for the period July 8 through July 12, 2006.

(table 3). The lack of significance of the streamflow difference is probably related to variability in the data from Fourmile and differences in snowmelt hydrograph timing (earlier melting at Fourmile) between the two sites as a result of canopy loss in the Fourmile watershed, contributing to uncertainty in the statistical comparison. Time-series trends in postfire instantaneousstreamflow measurements also were not statistically significant (p-value $<0.10$ ), as indicated by the seasonal Kendall trend analysis (tables 4 and 5).

For the 2 years that streamflow was recorded at Fourmile, daily mean streamflow was slightly larger in 2004 (mean $1.20 \mathrm{ft}^{3} / \mathrm{s}$ ) than in $2003\left(\right.$ mean $\left.0.91 \mathrm{ft}^{3} / \mathrm{s}\right)$. Generally, there was a rise in streamflow in April and May (figs. 11 and 12) indicating the influence of snowmelt and spring precipitation on streamflow. Although Fourmile was never observed dry during 2003 and 2004, daily mean streamflow was often less than $2 \mathrm{ft}^{3} / \mathrm{s}$ during the April through September period (Crowfoot and others, 2004, 2005).

Streamflow from the South Platte Trumbull streamgage was used to provide insights about runoff during the entire study period (2003-2007) in the burned area downstream from Cheesman Lake that includes Fourmile, where limited streamflow data (seasonal 2003-2004) were available. The difference between the daily mean streamflow at South Platte Trumbull and the gaged outflow from the Lake was be used as an estimate of the streamflow from tributaries below the reservoir such as Wigwam, Fourmile, Horse, and Brush Creeks, that were burned in the Hayman fire. Streamflow differences in the South Platte River between Cheesman Lake and South Platte Trumbull indicated that the probability of the sum of streamflows downstream from Cheesman Lake was greater than zero about 90 percent of the time, and about 10 percent of the daily sum of tributary inflows were greater than $70 \mathrm{ft}^{3} / \mathrm{s}$.

Inflows between Cheesman Lake and South Platte Trumbull in 2003 and 2004 were the smallest during the 5-year study period (2003-2007) with 2005 and 2007 having comparatively larger annual tributary streamflows (fig. 13). The differences in mean monthly streamflow (2003 through 2007) indicated that the largest streamflows in the watersheds downstream from Cheesman Lake occurred during March through May, which corresponds to the snowmelt period (fig. 14). The summer and early fall streamflow (June through September) was only slightly greater on a monthly basis than during the late fall and winter period (October through February) (fig. 14).

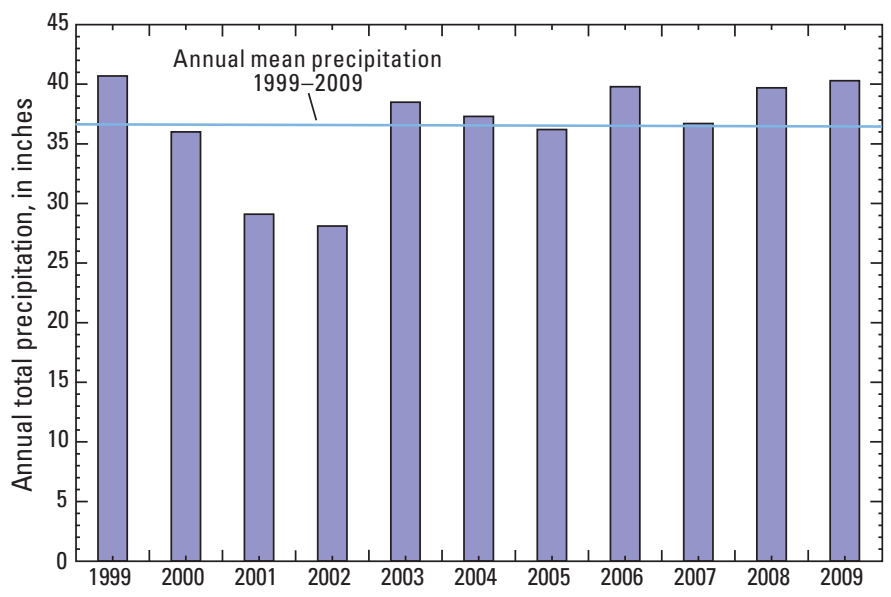

Figure 7. Graph showing annual total precipitation for the Lost Dog SNOTEL site for 1999 through 2009.

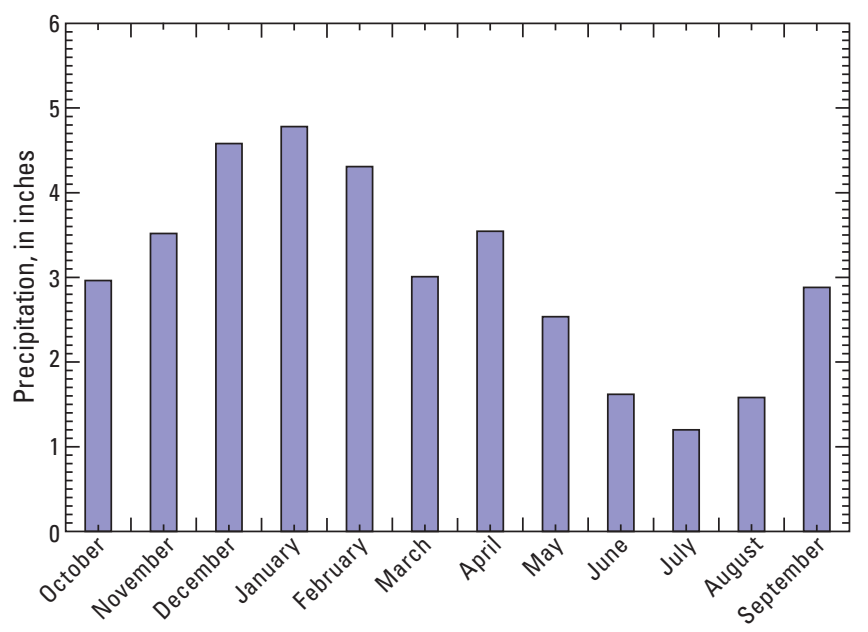

Figure 8. Graph showing distribution of average monthly precipitation at the Lost Dog SNOTEL site for the period 1999 through 2009. 


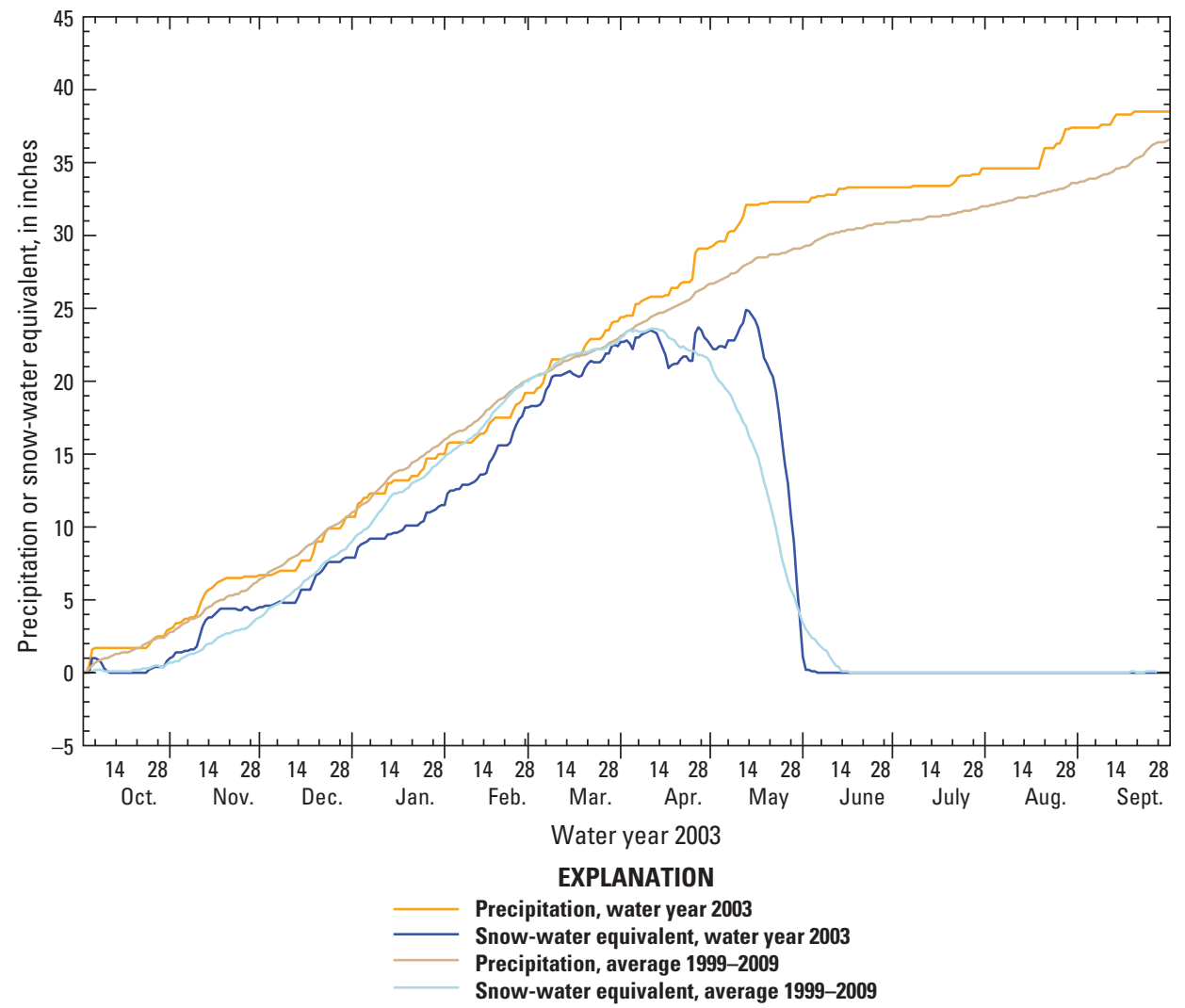

Figure 9. Graph showing daily total precipitation, snow-water equivalent at Lost Dog SNOTEL station, 2003 compared to 1999 through 2009 average.

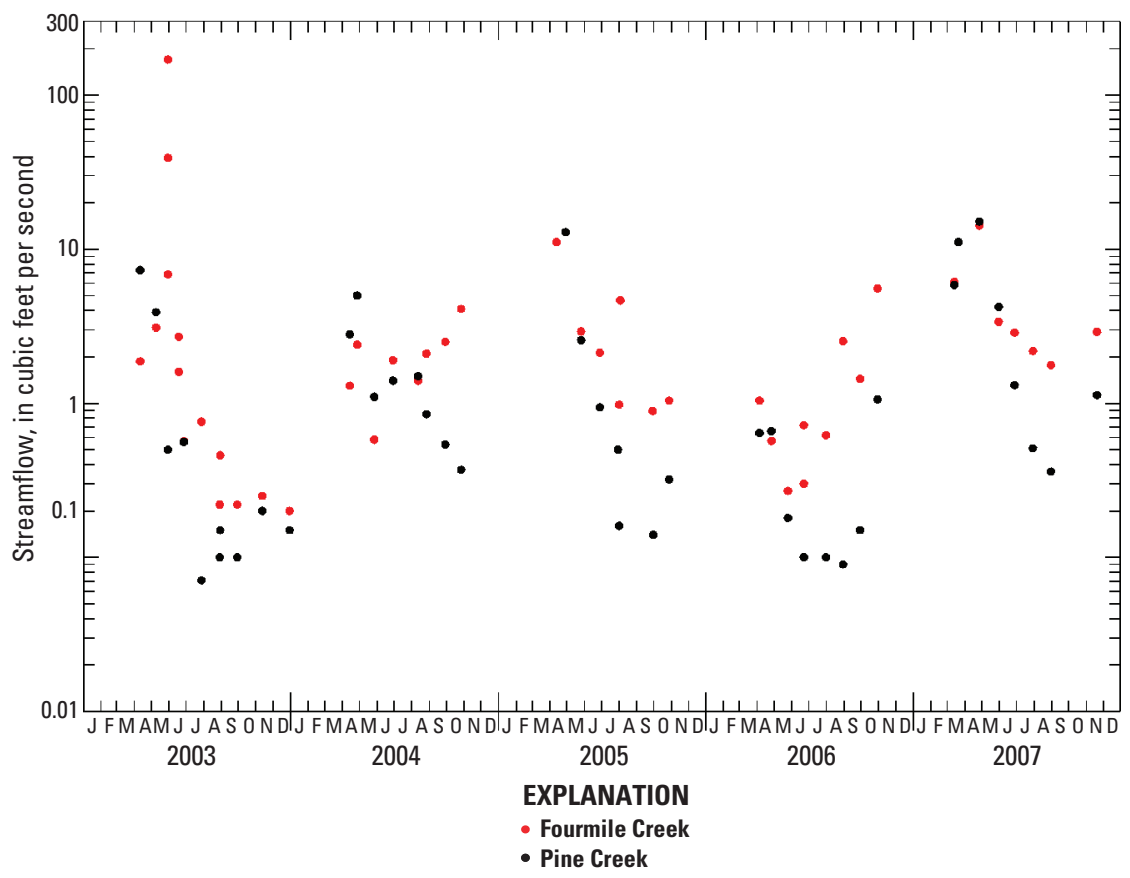

Figure 10. Graph showing instantaneous streamflow measured during water-quality sampling at Fourmile Creek and Pine Creek, 2003 through 2007. 
Table 3. Results of Wilcoxon signed-rank test of differences between paired samples (nonstorm only) of water-quality measurements, concentrations, and loads normalized to drainage area at Fourmile and Pine Creeks, 2003-2007.

[No pairs were available for rainstorm events so comparisons are for nonstorm samples, so medians at Fourmile are not equivalent to medians in appendix 2 ; specific conductance, turbidity, and ultraviolet absorption at $254 \mathrm{~nm}$ are multiplied by streamflow but are not mass loads; n, number of samples; -, no data; shaded values indicate a larger median that is considered statistically significant for this report with a p-value less than or equal to 0.10 ; mg/L, milligrams per liter; $\mathrm{mi}^{2}$, square mile; $\mu \mathrm{g} / \mathrm{L}$, micrograms per liter; ${ }^{\circ} \mathrm{C}$, degrees Celsius; $\mathrm{ft}^{3} / \mathrm{s}$, cubic feet per second; $\mu \mathrm{S} / \mathrm{cm}$ at $25^{\circ} \mathrm{C}$, microsiemens per centimeter at $25^{\circ} \mathrm{C}$; $\mu \mathrm{S}-\mathrm{ft}^{3} / \mathrm{cm}-\mathrm{s} / \mathrm{mi}^{2}$, streamflow-weighted specific conductance normalized to drainage area in microsiemens cubic feet per centimeter seconds per square mile; $\mathrm{AU} / \mathrm{cm}$, absorbance units per centimeter; $\mathrm{AU}-\mathrm{ft}^{3} / \mathrm{cm}-\mathrm{s} / \mathrm{mi}^{2}$, streamflow-weighted absorbance normalized to drainage area in absorbance unit-cubic feet per second per centimeter-second per square mile; NTU-ft $\mathrm{ft}^{3} / \mathrm{s} / \mathrm{mi}^{2}$, streamflow-weighted turbidity normalized to drainage area in nephelometric turbidity units cubic feet per second per square mile; $\mathrm{lb} / \mathrm{d} / \mathrm{mi}^{2}$, pounds per day per square mile; $\mathrm{CaCO}_{3}$, calcium carbonate; $\mathrm{N}$, nitrogen; $\mathrm{P}$, phosphorus; $\mathrm{C}$, carbon; nm, nanometers; $\mathrm{cm}$, centimeter; $\mathrm{lb} / \mathrm{d}$, pounds per day; $\mathrm{t} / \mathrm{d}$, tons per day; $\mathrm{t} / \mathrm{d} / \mathrm{mi}^{2}$, tons per day per square mile]

\begin{tabular}{|c|c|c|c|c|c|c|c|c|}
\hline $\begin{array}{l}\text { Water-quality constituent or measurement } \\
\text { (concentration unit; load unit) }\end{array}$ & \multicolumn{4}{|c|}{ Median value or concentration } & \multicolumn{4}{|c|}{$\begin{array}{l}\text { Median load normalized } \\
\text { to drainage area }\end{array}$} \\
\hline Streamflow, instantaneous, $\mathrm{ft}^{3} / \mathrm{s} ;-$ & 40 & 1.82 & 0.60 & 0.2369 & 40 & - & - & - \\
\hline Specific conductance, field, $\mu \mathrm{S} / \mathrm{cm}$ at $25^{\circ} \mathrm{C} ; \mu \mathrm{S}-\mathrm{ft}^{3} / \mathrm{cm}-\mathrm{s} / \mathrm{mi}^{2}$ & 40 & 148 & 18 & 0.0007 & 40 & 273 & 10 & $<0.0001$ \\
\hline $\mathrm{pH}$, lab, standard units; - & 38 & 7.7 & 7.7 & 0.8579 & 38 & - & - & - \\
\hline Calcium, dissolved, $\mathrm{mg} / \mathrm{L} ; \mathrm{lb} / \mathrm{d} / \mathrm{mi}^{2}$ & 36 & 18.6 & 12.9 & 0.0001 & 36 & 29.6 & 7.1 & $<0.0001$ \\
\hline Magnesium, dissolved, $\mathrm{mg} / \mathrm{L} ; \mathrm{lb} / \mathrm{d} / \mathrm{mi}^{2}$ & 36 & 2.3 & 1.9 & 0.0470 & 36 & 3.4 & 1.1 & $<0.0001$ \\
\hline Sodium, dissolved, $\mathrm{mg} / \mathrm{L} ; \mathrm{lb} / \mathrm{d} / \mathrm{mi}^{2}$ & 26 & 5.7 & 4.8 & $<0.0001$ & 26 & 6.8 & 2.1 & $<0.0001$ \\
\hline Potassium, dissolved; $\mathrm{lb} / \mathrm{d} / \mathrm{mi}^{2}$ & 26 & 2.6 & 1.9 & $<0.0001$ & 26 & 3.1 & 0.8 & $<0.0001$ \\
\hline Acid-neutralizing capacity, $\mathrm{mg} / \mathrm{L}$ as $\mathrm{CaCO}_{3} ; \mathrm{lb} / \mathrm{d} / \mathrm{mi}^{2}$ & 26 & 42 & 43 & $<0.0001$ & 26 & 54 & 16.7 & 0.0292 \\
\hline Sulfate, dissolved, $\mathrm{mg} / \mathrm{L} ; \mathrm{lb} / \mathrm{d} / \mathrm{mi}^{2}$ & 35 & 14.6 & 8.7 & $<0.0001$ & 35 & 24 & 5.1 & $<0.0001$ \\
\hline Nitrogen, nitrite plus nitrate, dissolved as $\mathrm{N}, \mathrm{mg} / \mathrm{L} ; \mathrm{lb} / \mathrm{d} / \mathrm{mi}^{2}$ & 37 & 0.490 & 0.097 & $<0.0001$ & 37 & 0.532 & 0.0792 & $<0.0001$ \\
\hline Nitrogen, ammonia, dissolved as $\mathrm{N}, \mathrm{mg} / \mathrm{L} ; \mathrm{lb} / \mathrm{d} / \mathrm{mi}^{2}$ & 37 & 0.008 & 0.008 & 0.3656 & 37 & 0.0088 & 0.0039 & 0.4533 \\
\hline Nitrogen, ammonia plus organic, dissolved as $\mathrm{N}, \mathrm{mg} / \mathrm{L} ; \mathrm{lb} / \mathrm{d} / \mathrm{mi}^{2}$ & 35 & 0.18 & 0.12 & 0.5728 & 35 & 0.212 & 0.1067 & 0.2174 \\
\hline Nitrogen, ammonia plus organic, total as $\mathrm{N}, \mathrm{mg} / \mathrm{L} ; \mathrm{lb} / \mathrm{d} / \mathrm{mi}^{2}$ & 37 & 4.90 & 0.15 & $<0.0001$ & 37 & 0.621 & 0.068 & $<0.0001$ \\
\hline Phosphorus, total as $\mathrm{P}, \mathrm{mg} / \mathrm{L} ; \mathrm{lb} / \mathrm{d} / \mathrm{mi}^{2}$ & 37 & 0.148 & 0.012 & $<0.0001$ & 37 & 0.156 & 0.005 & $<0.0001$ \\
\hline Phosphorus, dissolved as $\mathrm{P}, \mathrm{mg} / \mathrm{L} ; \mathrm{lb} / \mathrm{d} / \mathrm{mi}^{2}$ & 36 & 0.016 & 0.006 & $<0.0001$ & 36 & 0.019 & 0.003 & $<0.0001$ \\
\hline Phosphorus, ortho, dissolved as $\mathrm{P}, \mathrm{mg} / \mathrm{L} ; \mathrm{lb} / \mathrm{d} / \mathrm{mi}^{2}$ & 37 & 0.012 & 0.004 & $<0.0001$ & 37 & 0.016 & 0.002 & $<0.0001$ \\
\hline Carbon, organic, dissolved as $\mathrm{C}, \mathrm{mg} / \mathrm{L} ; \mathrm{lb} / \mathrm{d} / \mathrm{mi}^{2}$ & 36 & 2.70 & 3.0 & 0.1708 & 36 & 3.9 & 1.4 & 0.9446 \\
\hline Carbon, organic, total as $\mathrm{C}, \mathrm{mg} / \mathrm{L} ; \mathrm{lb} / \mathrm{d} / \mathrm{mi}^{2}$ & 30 & 5.1 & 2.2 & $<0.0001$ & 30 & 7.1 & 1.4 & 0.0002 \\
\hline Ultraviolet absorption at $254 \mathrm{~nm} ; \mathrm{AU} / \mathrm{cm} ; \mathrm{AU}-\mathrm{ft}^{3} / \mathrm{cm}-\mathrm{s} / \mathrm{mi}^{2}$ & 8 & 0.12 & 0.06 & 0.0797 & 8 & 0.013 & 0.018 & 0.6383 \\
\hline \multicolumn{9}{|l|}{ 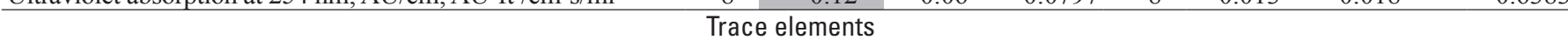 } \\
\hline Aluminum, dissolved, $\mu \mathrm{g} / \mathrm{L} ; \mathrm{lb} / \mathrm{d} / \mathrm{mi}^{2}$ & 9 & 11 & 5 & 0.0075 & 9 & 0.0052 & 0.0011 & 0.5478 \\
\hline Iron, total recoverable, $\mu \mathrm{g} / \mathrm{L} ; \mathrm{lb} / \mathrm{d} / \mathrm{mi}^{2}$ & 36 & 4,230 & 181 & $<0.0001$ & 36 & 5.489 & 0.062 & $<0.0001$ \\
\hline Lead, dissolved, $\mu \mathrm{g} / \mathrm{L} ; \mathrm{lb} / \mathrm{d} / \mathrm{mi}^{2}$ & 36 & 0.04 & 0.04 & 0.2328 & 36 & 0.00007 & 0.00002 & 0.2426 \\
\hline Lead, total recoverable, $\mu \mathrm{g} / \mathrm{L} ; \mathrm{lb} / \mathrm{d} / \mathrm{mi}^{2}$ & 36 & 9.80 & 0.15 & $<0.0001$ & 36 & 0.01153 & 0.00005 & $<0.0001$ \\
\hline Manganese, dissolved, $\mu \mathrm{g} / \mathrm{L} ; \mathrm{lb} / \mathrm{d} / \mathrm{mi}^{2}$ & 36 & 10.7 & 10.7 & 10.0098 & 36 & 0.00198 & 0.00061 & 0.0026 \\
\hline Manganese, total recoverable, $\mu \mathrm{g} / \mathrm{L} ; \mathrm{lb} / \mathrm{d} / \mathrm{mi}^{2}$ & 36 & 410 & 6.0 & $<0.0001$ & 36 & 0.4084 & 0.0033 & $<0.0001$ \\
\hline Mercury, total recoverable, $\mu \mathrm{g} / \mathrm{L} ; \mathrm{lb} / \mathrm{d} / \mathrm{mi}^{2}$ & 35 & 0.001 & 0.0009 & 0.0015 & 35 & 0.000012 & 0.0000044 & 0.0005 \\
\hline Zinc, dissolved, $\mu \mathrm{g} / \mathrm{L} ; \mathrm{lb} / \mathrm{d} / \mathrm{mi}^{2}$ & 34 & 0.6 & 1.0 & 0.3504 & 34 & 0.0012 & 0.0008 & 0.9863 \\
\hline Zinc, total recoverable, $\mu \mathrm{g} / \mathrm{L} ; \mathrm{lb} / \mathrm{d} / \mathrm{mi}^{2}$ & 35 & 34 & 2.0 & $<0.0001$ & 35 & 0.0537 & 0.0009 & $<0.0001$ \\
\hline \multicolumn{9}{|c|}{ Sediment } \\
\hline Sediment, suspended, $\mathrm{mg} / \mathrm{L} ; \mathrm{t} / \mathrm{d} / \mathrm{mi}^{2}$ & 36 & 422 & 6 & $<0.0001$ & 36 & 0.1331 & 0.0011 & $<0.0001$ \\
\hline
\end{tabular}

${ }^{1}$ Although median values are commonly shown with signed-rank and rank sum test p-values to provide context, these tests are not median tests. Rarely, comparison data have significantly different distributions but have the same or similar median values. 
Table 4. Seasonal Kendall trend-analysis results for LOWESS streamflow-adjusted water-quality measurements and constituent concentrations at Fourmile Creek, 2003-2007.

[Specific conductance and turbidity are multiplied by streamflow but are not mass loads; --, insufficient data; shaded values indicate a statistically significant trend for this report with a p-value less than or equal to 0.10 ; upward, statistically significant upward trend over the period of analysis; downward, statistically significant downward trend over the period of analysis; $\mathrm{mg} / \mathrm{L}$, milligrams per liter; $\mu \mathrm{g} / \mathrm{L}$, micrograms per liter; ${ }^{\circ} \mathrm{C}$, degrees Celsius; $\mathrm{ft}^{3} / \mathrm{s}$, cubic feet per second; $\mu \mathrm{S} / \mathrm{cm}$ at $25{ }^{\circ} \mathrm{C}$, microsiemens per centimeter at $25^{\circ} \mathrm{C}$; NTU, nephelometric turbidity units; $\mathrm{CaCO}_{3}$, calcium carbonate; N, nitrogen; $\mathrm{P}$, phosphorus; $\mathrm{C}$, carbon; $\mathrm{nm}$, nanometers; $\mathrm{cm}$, centimeter]

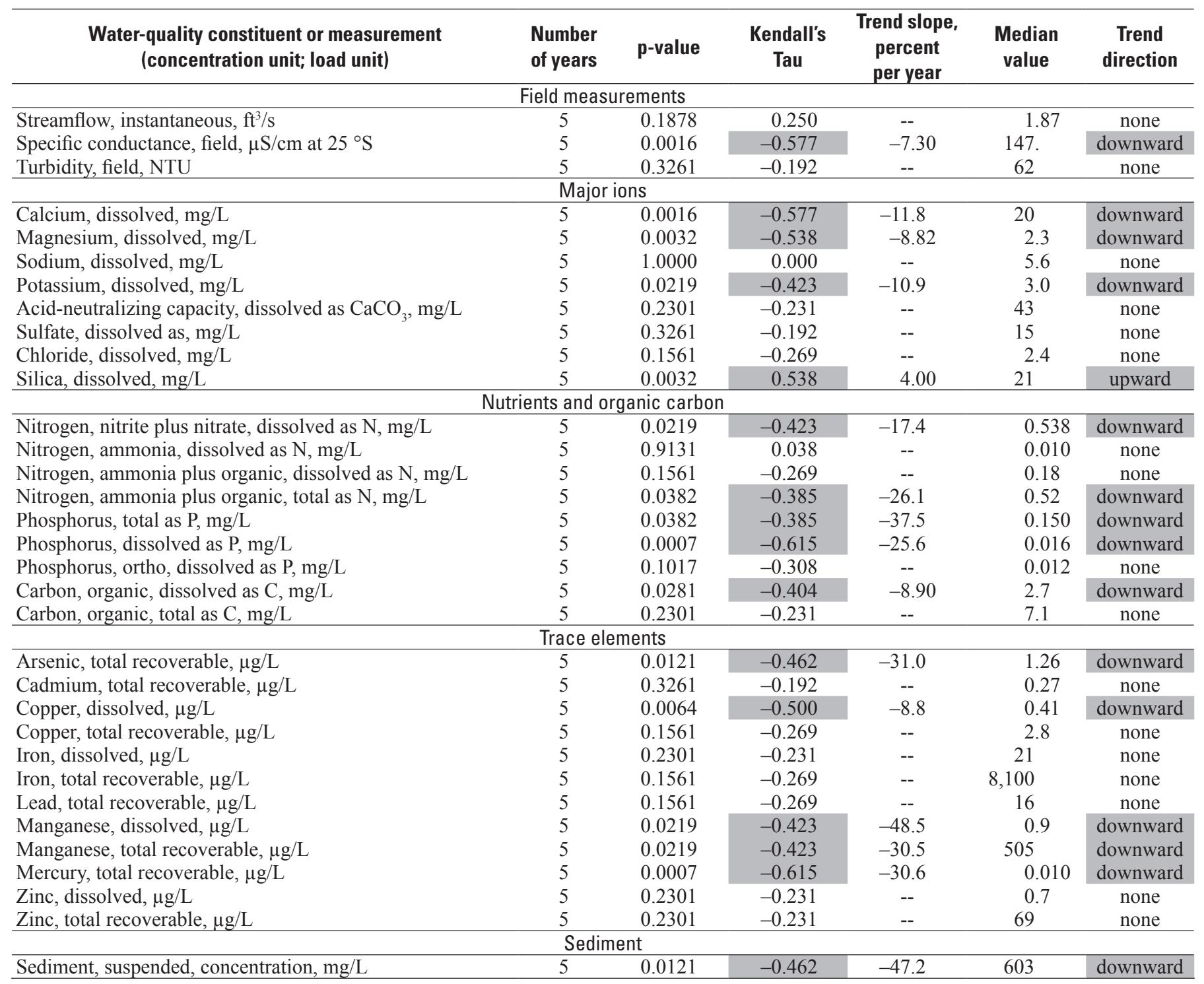


Table 5. Seasonal Kendall trend-analysis results for LOWESS streamflow-adjusted water-quality measurements and constituent concentrations at Pine Creek, 2003-2007.

[Specific conductance and turbidity are multiplied by streamflow but are not mass loads; $n$, number of samples; --, insufficient data; shaded values indicate a statistically significant trend for this report with a p-value less than or equal to 0.10 ; up, statistically significant upward trend over the period of analysis; down, statistically significant downward trend over the period of analysis; $\mathrm{mg} / \mathrm{L}$, milligrams per liter; $\mu \mathrm{g} / \mathrm{L}$, micrograms per liter; ${ }^{\circ} \mathrm{C}$, degrees Celsius; $\mathrm{ft}^{3} / \mathrm{s}$, cubic feet per second; $\mu \mathrm{S} / \mathrm{cm}$ at $25^{\circ} \mathrm{C}$, microsiemens per centimeter at $25^{\circ} \mathrm{C} ; \mathrm{NTU}$, nephelometric turbidity units; $\mathrm{CaCO}_{3}$, calcium carbonate; $\mathrm{N}$, nitrogen; P, phosphorus; $\mathrm{C}$, carbon; nm, nanometers; cm, centimeter]

\begin{tabular}{|c|c|c|c|c|c|c|}
\hline $\begin{array}{l}\text { Water-quality constituent or measurement } \\
\text { (concentration unit; load unit) }\end{array}$ & $\begin{array}{l}\text { Number } \\
\text { of years }\end{array}$ & p-value & $\begin{array}{l}\text { Kendall's } \\
\text { Tau }\end{array}$ & $\begin{array}{c}\text { Trend slope, } \\
\text { percent } \\
\text { per year }\end{array}$ & $\begin{array}{l}\text { Median } \\
\text { value }\end{array}$ & $\begin{array}{l}\text { Trend } \\
\text { direction }\end{array}$ \\
\hline \multicolumn{7}{|c|}{ Field measurements } \\
\hline Specific conductance, field, $\mu \mathrm{S} / \mathrm{cm}$ at $25^{\circ} \mathrm{C}$ & 5 & 0.4996 & -0.143 & -- & 112 & none \\
\hline Turbidity, field, NTU & 5 & 0.4764 & -0.156 & -- & 1.90 & none \\
\hline \multicolumn{7}{|c|}{ Major ions } \\
\hline Potassium, dissolved, $\mathrm{mg} / \mathrm{L}$ & 4 & -- & -- & -- & -- & -- \\
\hline Acid-neutralizing capacity, dissolved as $\mathrm{CaCO}_{3}, \mathrm{mg} / \mathrm{L}$ & 4 & -- & -- & -- & -- & -- \\
\hline Sulfate, dissolved, $\mathrm{mg} / \mathrm{L}$ & 5 & 0.5854 & -0.115 & -- & 9.0 & none \\
\hline Chloride, dissolved, $\mathrm{mg} / \mathrm{L}$ & 4 & -- & -- & -- & -- & -- \\
\hline Silica, dissolved, mg/L & 4 & -- & -- & -- & -- & -- \\
\hline \multicolumn{7}{|c|}{ Nutrients and organic carbon } \\
\hline Phosphorus, total as $\mathrm{P}, \mathrm{mg} / \mathrm{L}$ & 5 & 0.4450 & 0.154 & -- & 0.013 & none \\
\hline Phosphorus, dissolved as $\mathrm{P}, \mathrm{mg} / \mathrm{L}$ & 5 & 1.0000 & 0.000 & -- & 0.006 & none \\
\hline Phosphorus, ortho, dissolved as $\mathrm{P}, \mathrm{mg} / \mathrm{L}$ & 5 & 0.0636 & 0.346 & 14.6 & 0.004 & up \\
\hline Carbon, organic, dissolved as $\mathrm{C}, \mathrm{mg} / \mathrm{L}$ & 5 & 0.0219 & 0.423 & 12.8 & 3.2 & up \\
\hline Carbon, organic, total as $\mathrm{C}, \mathrm{mg} / \mathrm{L}$ & 5 & -- & -- & -- & -- & -- \\
\hline \multicolumn{7}{|c|}{ Trace elements } \\
\hline Arsenic, total recoverable, $\mu \mathrm{g} / \mathrm{L}$ & 4 & -- & -- & -- & -- & -- \\
\hline Cadmium, total recoverable, $\mu \mathrm{g} / \mathrm{L}$ & 5 & -- & -- & -- & -- & -- \\
\hline Copper, dissolved, $\mu \mathrm{g} / \mathrm{L}$ & 5 & -- & -- & -- & -- & -- \\
\hline Copper, total recoverable, $\mu \mathrm{g} / \mathrm{L}$ & 5 & 0.2301 & -0.231 & -- & 0.49 & none \\
\hline Iron, dissolved, $\mu \mathrm{g} / \mathrm{L}$ & 5 & 0.1561 & -0.269 & -- & 0.61 & none \\
\hline Iron, total recoverable, $\mu \mathrm{g} / \mathrm{L}$ & 5 & 0.9131 & 0.038 & -- & 8 & none \\
\hline \multicolumn{7}{|c|}{ Sediment } \\
\hline Sediment, suspended, concentration, $\mathrm{mg} / \mathrm{L}$ & 5 & 0.7434 & -0.077 & -- & 8 & none \\
\hline
\end{tabular}




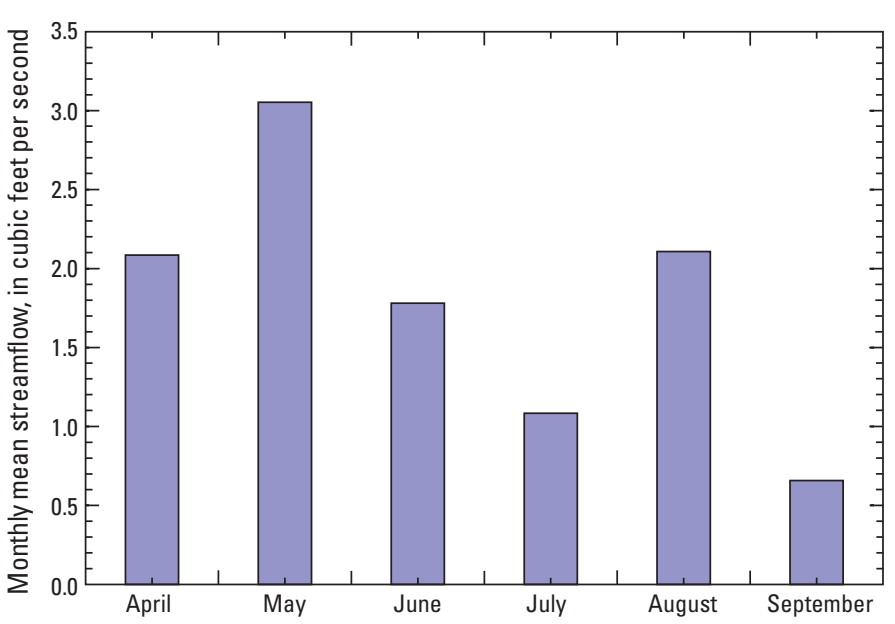

Figure 11. Graph showing distribution of monthly mean streamflow (April through September) at Fourmile Creek, 2003 and 2004.

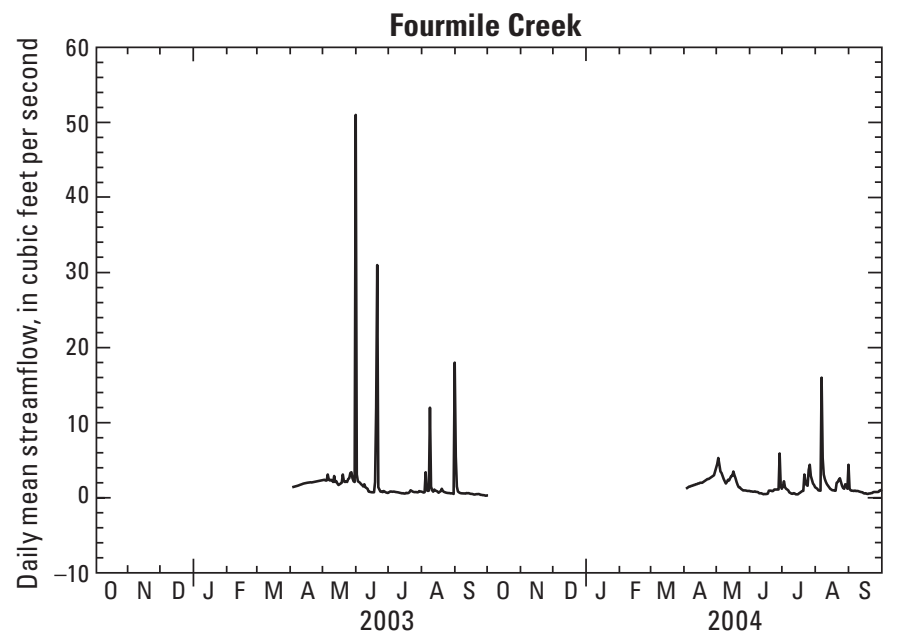

Figure 12. Hydrograph showing daily mean at Fourmile Creek, 2003 through 2004.

\section{Flooding}

Rainstorms can produce large streamflow runoff in the Hayman fire study area. Storms producing 1-2 in. of rain are possible in the area (Buffalo Creek and Spring Creek) (Fulton, 1999; Crowfoot and others, 2001). Specific examples were previously described in the "Precipitation Hayman Fire Study Area" section. At the unburned stream, Pine, rainstorm-runoff never occurred contemporaneously with rainstorm runoff at Fourmile, and no evidence of rainfall-related high water or flooding was observed at Pine for the duration of the study (although it did rain in the watershed). Overland flow that can cause stream flooding is rare in undisturbed and unburned forested settings (Ward and Elliot, 1995). Frontal-type storms and monsoon periods may cause high streamflows for several days, but floods are generally associated with short, intense thunderstorms that produce more than 0.39 in. of rain in 30 min (Moody and Martin, 2001b). High streamflows in the South Platte River also can occur during large releases of stored water from Cheesman Lake. The 1-percent annual exceedance probability peak streamflow (hereinafter referred to as the "100-year flood") at the mouth of the Fourmile watershed (Elliott and others, 2005) before the Hayman fire was estimated to be $77.2 \mathrm{ft}^{3} / \mathrm{s}$ by using a hydrologic model. The postfire peak was estimated, also by using a hydrologic model, to be $1,850 \mathrm{ft}^{3} / \mathrm{s}$ (fig. 15) (Elliott and others, 2005). The effects of fire on flooding were exemplified by the May 30, 2003, rainstorm that produced an estimated 1 to 1.5 in. of rain in about 30 to 60 min over about one-half of the 7.4- $\mathrm{mi}^{2}$ Fourmile watershed (Crowfoot and others, 2004). This rainfall resulted in a flood on Fourmile with an estimated peakflow at the streamgage of $934 \mathrm{ft}^{3} / \mathrm{s}$, about 12 times the prefire estimated 100 -year recurrence peakflow (fig. 16).

Postfire hydrologic effects also were exemplified by a severe storm and ensuing flood recorded at the West Creek streamgage on July 7, 2006. The storm produced a flood along Trail Creek, West Creek, and Horse Creek (fig. 17) that caused approximately $\$ 11$ million in damage to Colorado State Highway 67 (Colorado Department of Transportation, 2006). Most of the flood flows originated in the Trail Creek and upper West Creek (above Trail Creek) watersheds. The streamflow increased from 62 to $2,170 \mathrm{ft}^{3} / \mathrm{s}$ in $45 \mathrm{~min}$ (USGS National Water Information System; data available from USGS Colorado Water Science Center, accessed October 2008) at the West Creek streamgage. As previously mentioned in the "Precipitation" section of this report, this flood was a result of 2.2 in. of rain in about $2 \mathrm{~h}$ (rain recorded at the West Creek streamgage corresponding to a maximum 30 -min intensity of $3.1 \mathrm{in} / \mathrm{h}$.

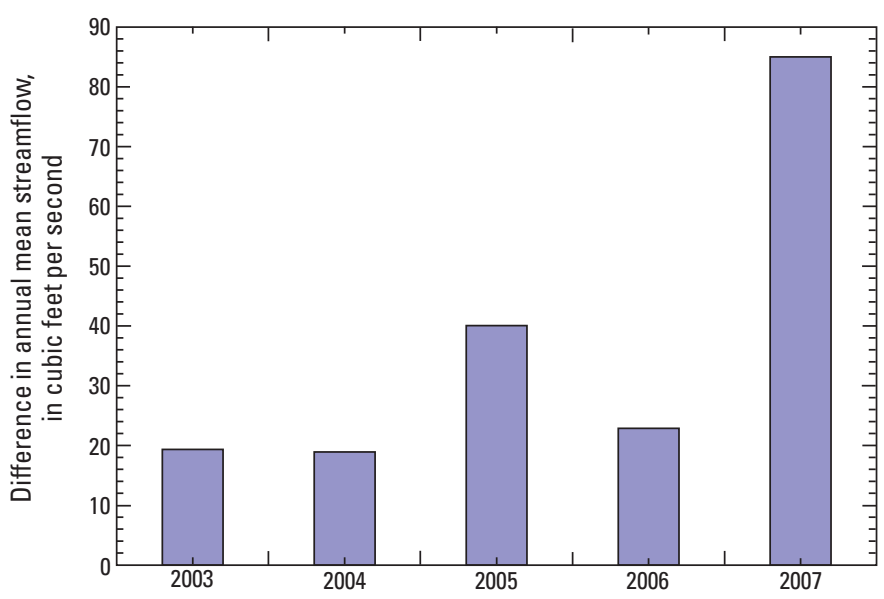

Figure 13. Graph showing annual mean streamflow difference between South Platte River below Cheesman Lake and South Platte River below Brush Creek near Trumbull streamgages, 2003 through 2007. 


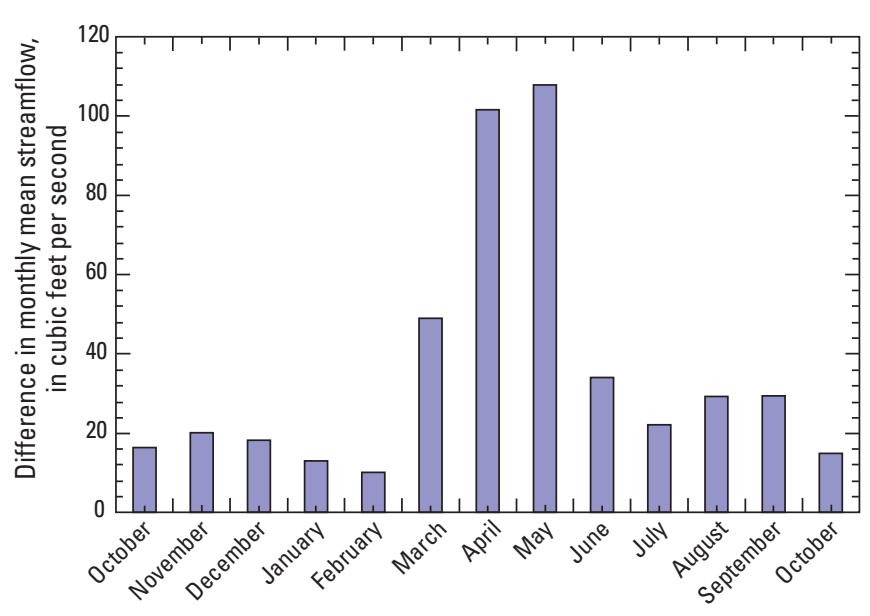

Figure 14. Graph showing distribution of monthly mean streamflow differences between South Platte River below Cheesman Lake and the South Platte River below Brush Creek near Trumbull streamgages, 2003 through 2007.

\section{Hinman Fire Study Area}

\section{Nonflood Flows}

Streamflows at the Elk River above Clark (located downstream from the North Fork Elk) are used in this report to show the general hydrology of the North Fork Elk and Lost Dog. In snowmelt-dominated hydrologic settings that characterize the North Fork Elk and Lost Dog, the rising limb of the hydrograph is a period when streamflows increase rapidly but still fluctuate in response to changes in air temperature and spring storms (fig. 18). In April or early May, warm air temperatures can cause limited melting, especially at lower elevations, which causes small rises in streamflow. Streamflow fluctuates daily in response to snowmelt, which can influence the concentrations of water-quality constituents and suspended sediment by dilution and physical suspension. Peak streamflow in the Hinman fire study area typically occurred between late May and mid-June (fig. 18). Annual seasonal (April-September) streamflow at Elk River above Clark in 2002 was the smallest during the 12-year record at this site (1988-1993 and 1998-2003) and streamflow in 2003 was the fourth largest of the 12 years of historical record (fig. 19). Highest monthly mean streamflows in the Hinman fire study area occurred in June (fig. 20). Streamflow rapidly decreased after the peak, and the decline typically slowed through July. Low streamflows (base flow) from about midSeptember to March occurred primarily beneath a cover of ice in midwinter and were supported by groundwater inflow to the streams. Instantaneous streamflows measured during waterquality sampling in 2003 showed much higher streamflows during snowmelt than those measured during the prefire period of 1999 and 2000 (fig. 21).

\section{Flooding}

Rainstorms in the Hinman fire study area occurred from May to September but were most common in July, August, and early September. Storm runoff from rainfall contributed relatively little to the total annual flow in streams and produced peak flows that were small compared to snowmelt peak flows. High elevations in Colorado (approximately greater than $7,500-\mathrm{ft}$, such as the Hinman fire area) rarely have convective rainstorms with enough intensity to produce large floods (Jarrett, 1990). Rainstorms capable of producing flash floods, however, do occur west of the Continental Divide but are generally rare and smaller than rainstorms east of the Continental Divide because of the lack of low-level moisture (Doesken and others, 2003).

Results of flood frequency computations (Vaill, 2000) indicated 10-year and 100-year flood peaks of 515 and $793 \mathrm{ft}^{3} / \mathrm{s}$ for North Fork Elk, and 84 and $126 \mathrm{ft}^{3} / \mathrm{s}$ for Lost Dog (U.S. Geological Survey, 2009). Despite an April 1 snow-waterequivalent that was near the 1999 through 2009 average (fig. 9), high runoff and local flooding were produced in 2003 in the burned area drained by the North Fork Elk (snowmelt peak measured 1,180 ft $3 / \mathrm{s}$ ) and Lost Dog (snowmelt peak measured $174 \mathrm{ft}^{3} / \mathrm{s}$ ) watersheds, which were about 50 percent and 38 percent larger, respectively, than the estimated 100-year flood.

The 0.2 -percent annual exceedance probability streamflow (500-year flood) estimate at Lost Dog was $154 \mathrm{ft}^{3} / \mathrm{s}$ (Vaill, 2000; U.S. Geological Survey, 2009). The highest instantaneous measurement in Lost Dog was $174 \mathrm{ft}^{3} / \mathrm{s}$ during the postfire 2003 snowmelt (fig. 21). This high snowmelt period after the Hinman fire overtopped the forest road culvert and the streambanks in many areas of the Lost Dog watershed (fig. 22). The estimated

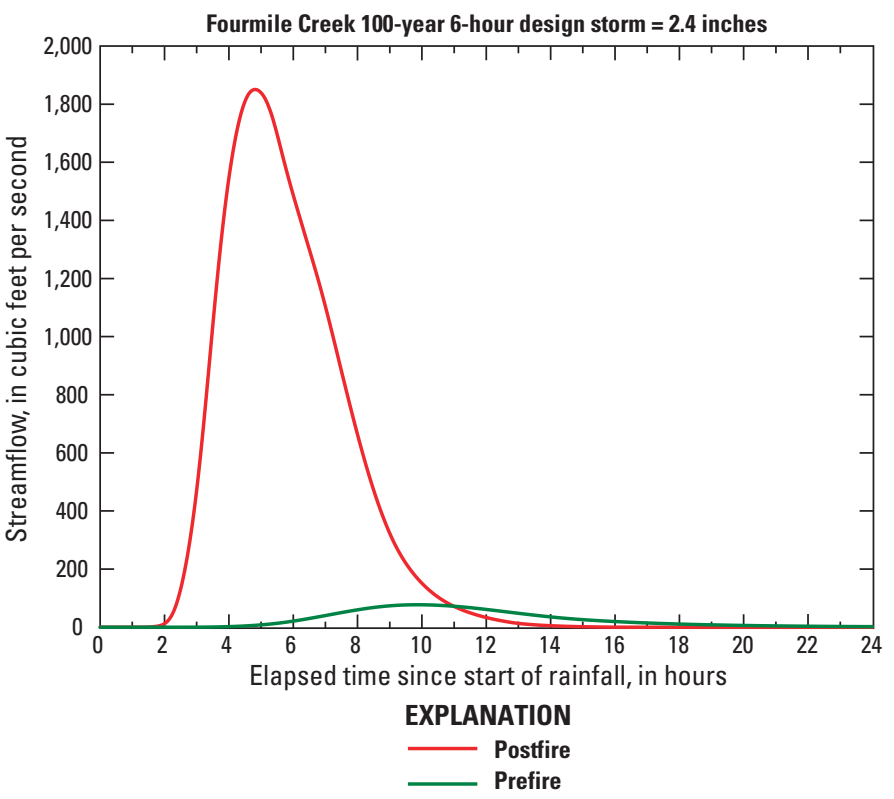

Figure 15. Estimated 100-year flood (the 1-percent annual exceedance probability flood event) hydrograph for Fourmile Creek based on hydrologic modeling (from Elliott and others, 2005). 

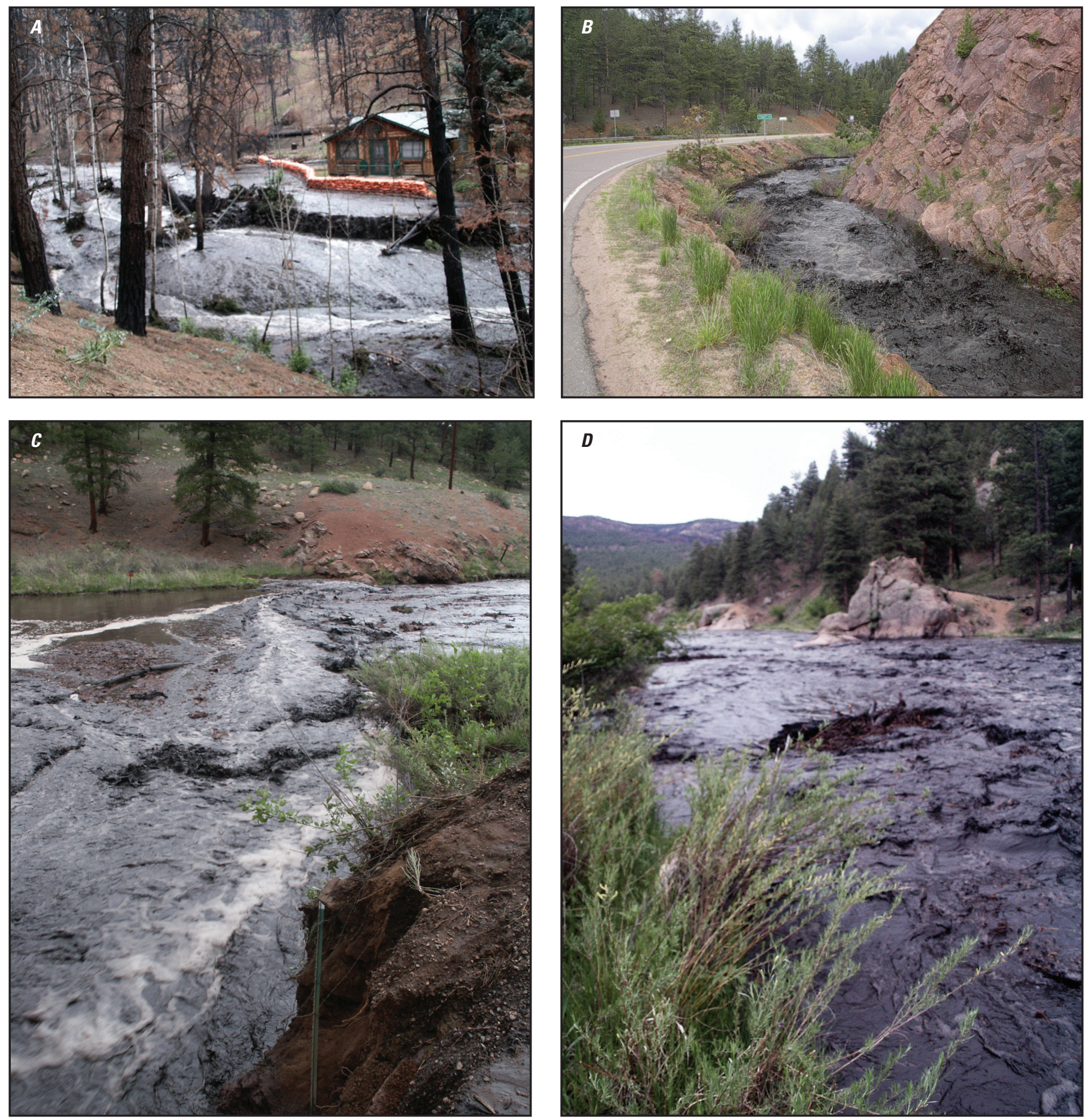

Figure 16. Photographs showing flooding May 30, 2003. $A$, along Fourmile Creek downstream from YMCA Camp Shady Brook; $B$, Horse Creek at mouth at Deckers (photograph taken by Rich Ommert, Moser and Associates Engineering, used with permission); $C$, Fourmile Creek at mouth at South Platte River; and D, South Platte River below Brush Creek near Trumbull. 

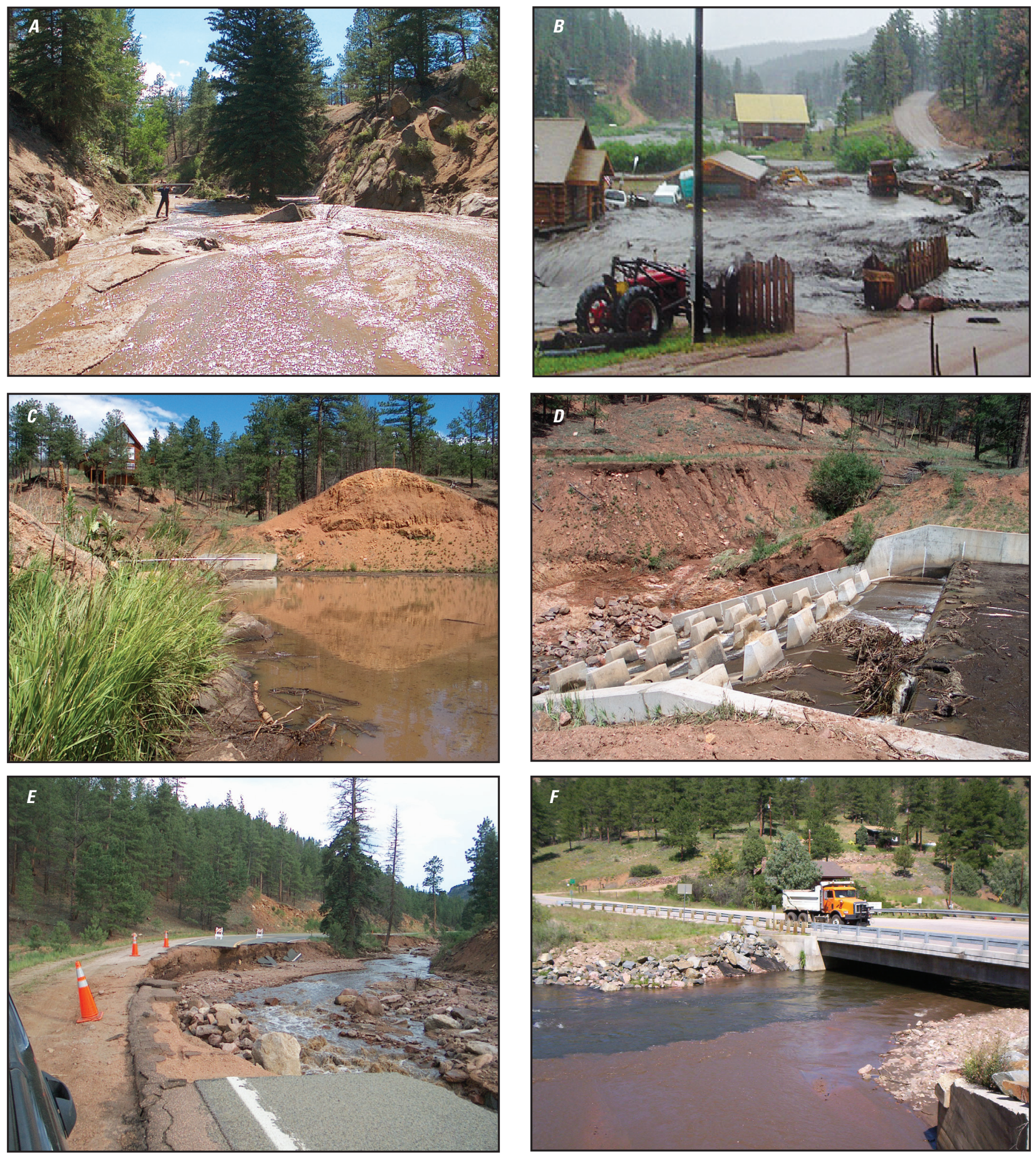

Figure 17. Photographs of damage from flood of July 7, 2006, along West Creek and Trail Creek. A, Peak flood height (man with rod) at Trail Creek about 1 mile upstream from confluence with West Creek; $B$, photograph taken during flood overtopping the road and box culvert on July 7, 2006, on Trail Creek at mouth at West Creek (flow direction from right to left, Douglas County photograph, used with permission); $C$, West Creek Lake dam — white survey rod indicates maximum height of water during flood; $D$, erosion along right spillway abutment of West Creek Lake dam; $E$, part of the flood damage along 5 miles of West Creek downstream from West Creek dam, along Highway 67, which cost $\$ 11$ million to repair; and $F$, sediment-laden Horse Creek entering the South Platte River at Deckers during upstream repairs to Highway 67 along West Creek on August 30, 2006. 


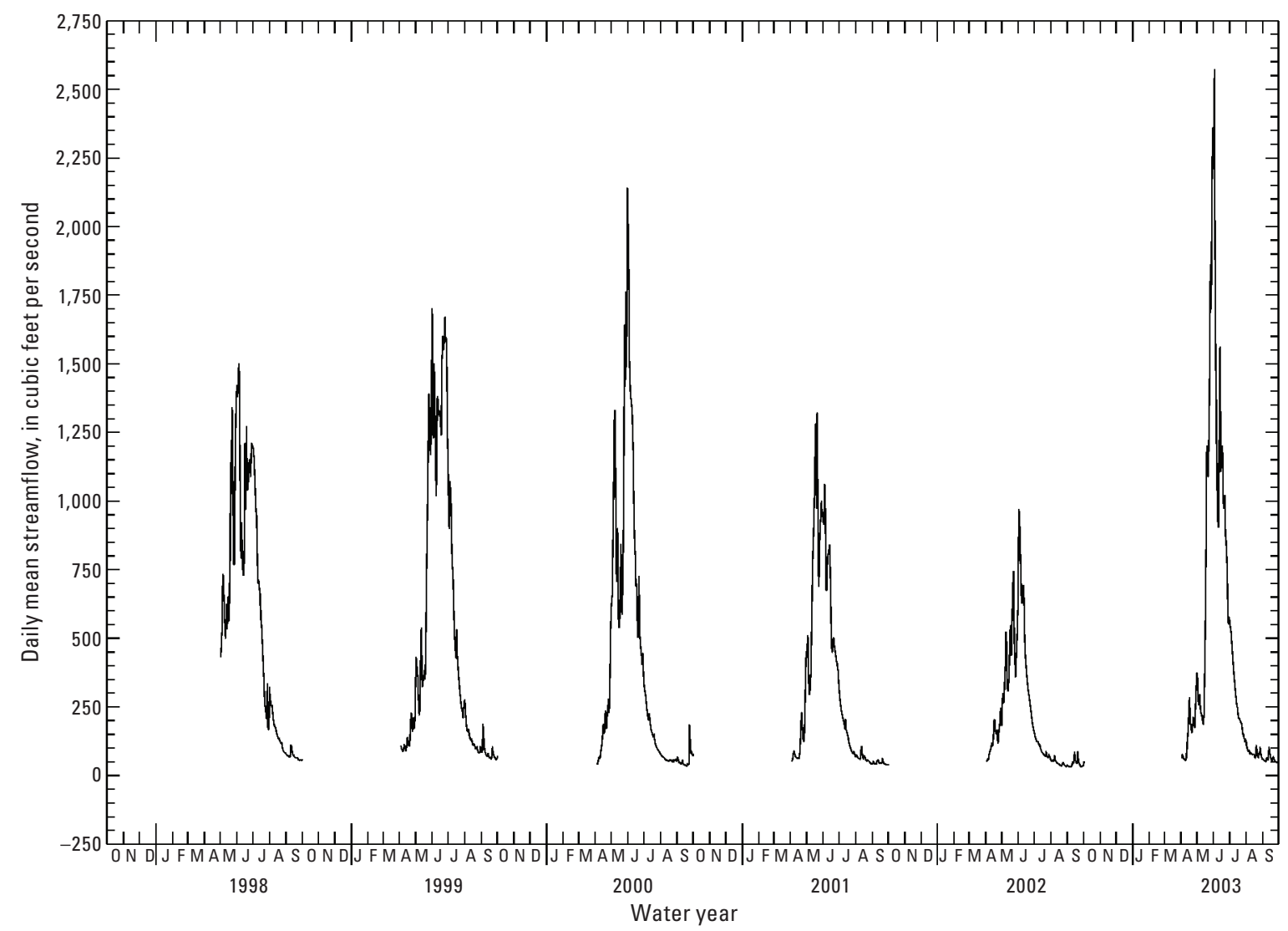

Figure 18. Graph showing daily mean streamflow at seasonal streamgage at Elk River above Clark, Colorado, 1998 through 2003.

500-year flood peak in the North Fork Elk before the Hinman fire was $979 \mathrm{ft}^{3} / \mathrm{s}$. The highest instantaneous streamflow measurement at North Fork Elk was 1,180 ft $3 / \mathrm{s}$ during the 2003 snowmelt. No substantial rainstorm flooding was observed during sampling at either Lost Dog or North Fork Elk; however, during the August 2003 sampling, it was observed that storm runoff was receding from a recent afternoon thunderstorm. These high streamflows (greater than the 500-year flood) during 2003 are additional evidence that the Hinman fire caused increased runoff in burned watersheds.

In addition to changes by fire to soil surface runoff characteristics, high streamflows may have been influenced by the 2003 snowpack that began melting in May rather than in April (a consequence of two late snowstorms) and melted more rapidly (possibly a consequence of less shading as a result of canopy removal by fire) than was indicated by the 11 -year average (fig. 9).

Snowmelt hydrology can be affected by wildfire. Helvey (1980) and Woodsmith and others (2007) reported that preliminary analysis, using monitoring data and a hydrologic model, indicated that snowmelt was affected by a 1970 fire in the Entiat Experimental Forest in Washington. Analysis indicated increases in snow accumulation, advancement of snowmelt timing, more rapid snowmelt, and increased streamflows (Woodsmith and others, 2007). The influence of fire on the snowmelt-dominated hydrology of the Hinman fire area is evident by examining the relation of the snow-water equivalent (U.S. Department of Agriculture, Natural Resources Conservation Service, 2009, [data for April 1 of each year, near full annual accumulation]) and peak streamflow measured at the Elk River above Clark streamgage (fig. 23). The drainage area for the streamgage includes the areas burned by both the Hinman and Burn Ridge fires. The Burn Ridge fire occurred in 2002 just south of the Hinman fire. Together they are known as the Zirkel Complex Fire (Colorado Department of Local Affairs, 2002). The relation between annual peak streamflow and April 1 snow-water equivalent was approximately linear for the years 1999 through 2002 (prefire) (fig. 23); however, the postburn 2003 data indicate that a smaller amount of snow-water equivalent produced about a 30-percent increase in the annual peak streamflow than would be predicted by the relation of peak flow and snow-water equivalent for the prefire years.

\section{Comparison of Hayman and Hinman Fire Study Results}

Analysis of instantaneous and limited continuous streamflow data indicated that fire increased streamflow substantially in both the rainfall (Hayman)- and snowmelt (Hinman)dominated hydrologic settings. Some high-flow events were 
missed during late summer of 2002, prior to the start of this study, which may be especially important in the Hayman fire study area. No substantial streamflow information was collected beyond the first postfire year at the Hinman streamflow sites, so no hydrologic recovery can be assessed in that area.

\section{Water Quality}

\section{Comparisons of Water Quality}

Fire changes the chemical composition of watershed runoff by affecting chemical transformations of burned vegetation and soils (Cade-Menun, 2000; Ceam and others, 2004; Neary and others, 2008; Parra and others, 1996; Gonzalez-Perez, 2004; Plumlee and others, 2007) and by altering biological activity (Gonzalez-Perez, 2004; Smithwick and others, 2005; Neary and others, 1999). Postfire precipitation contacts fire-affected material, including ash, charcoal, partially burned organic matter, and soil, and changes water chemistry. Hillslope runoff after fire generally increases and causes erosion and transport of chemical constituents associated with organic particulates or sediment. As a result, substantial changes in water quality can occur in streams receiving runoff from burned watersheds compared to streams receiving runoff from unburned watersheds. The USGS NWQL analyzed many chemical constituents in streamwater- and bed-sediment samples collected during the study including major ions, nutrients, organic carbon, trace elements, TICs, and THM formation potential. However, because of the large number of analytes, the focus of graphically represented data in this report is directed toward target analytes that are believed to be of most interest to water-resource and water-treatment managers including selected major ions (calcium, potassium, sulfate), nutrients (nitrate and phosphorus), organic carbon, and trace

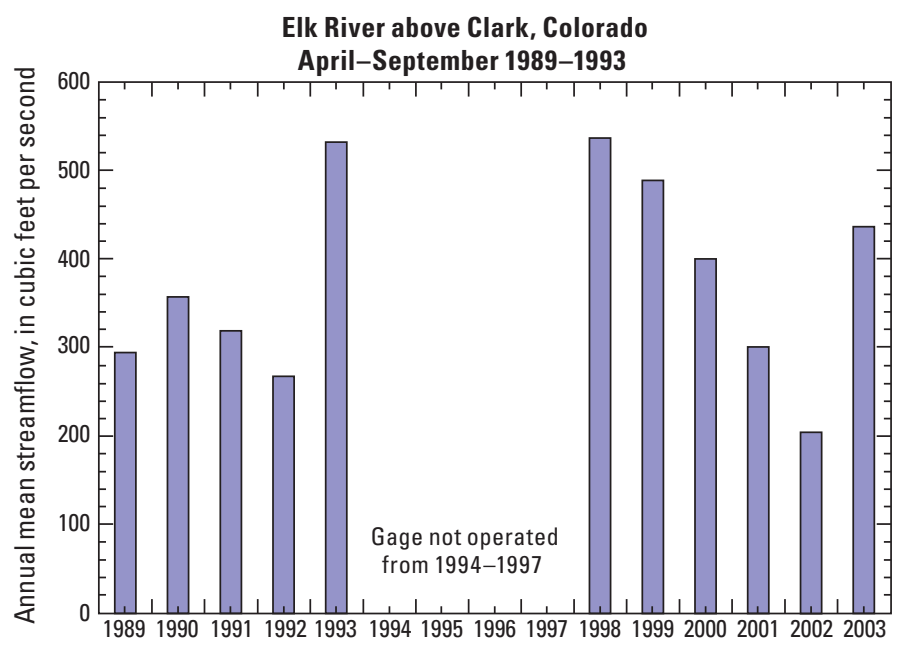

Figure 19. Graph showing annual mean streamflow at Elk River above Clark, Colorado for the period of record, (April-September) 1989-1993 and 1998-2003.

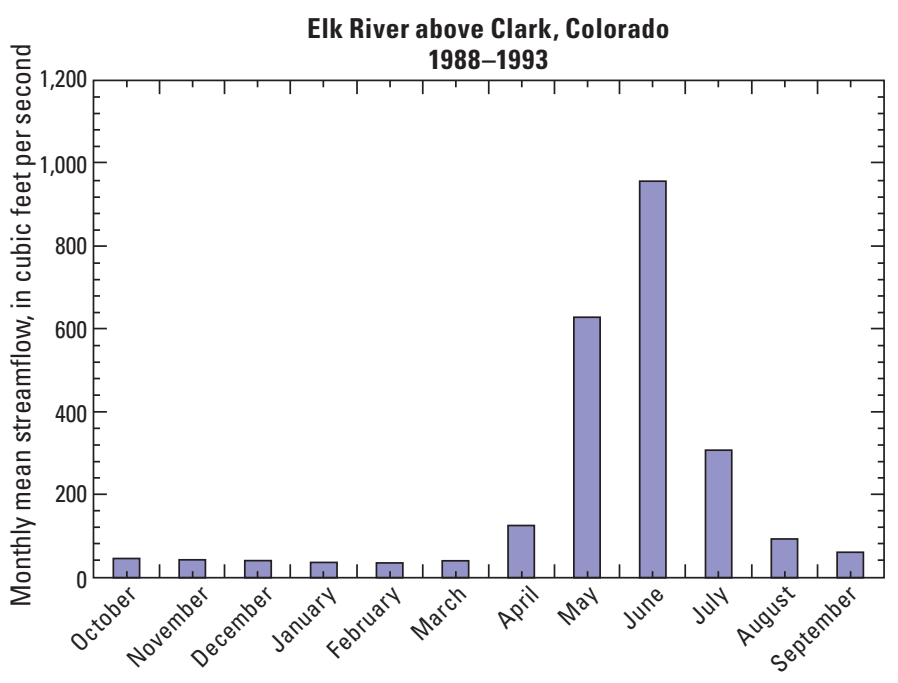

Figure 20. Graph showing monthly mean streamflow at Elk River above Clark, Colorado, for the period of record, 1988-1993.

elements (manganese and total recoverable mercury). This section of the report compares water quality in streams draining burned and unburned watersheds (Hayman fire) and prefire and postfire data (Hinman fire). Summary statistics for field measurements and analytes are listed in appendix 2 .

\section{Hayman Fire Study Area}

Fourmile and Pine watersheds are described here as a burned and (or) unburned paired-watershed comparison. This method was necessary because no substantial prefire waterquality data were available for small streams in the study area. However, a limited number of water-quality samples were collected at several streams during the immediate prefire and postfire period (2001-2003) by the USDA Forest Service (Deb Entwhistle, U.S. Department of Agriculture Forest Service, written commun., 2003; Libohova, 2004; Rhoades and others, 2006).

\section{Field and Laboratory Measurements and Major lons}

Summary statistics for field measurements and analytes are listed in appendix 2. Greater values of specific conductance and greater concentrations and loads of sulfate and potassium were found in burned Fourmile than in unburned Pine (figs. 24 and 25). Median concentrations also were greater for calcium, magnesium, sodium, chloride, and silica (appendix 2) in Fourmile than in Pine. Postfire stream chemistry at Fourmile and Pine was predominantly calcium and bicarbonate type (as indicated by acid-neutralizing capacity and $\mathrm{pH}$ ). Release of major ions from watersheds after a fire is well documented in literature on postfire effects (Giovannini and others, 1990; Bayley and others, 1992; Ceam and others, 2004; Plumlee and others, 2007). Ash residue, produced by pyrolysis of vegetation and surface soil, is rich in base cations, carbonates, hydroxides, and oxides that dissolve in 

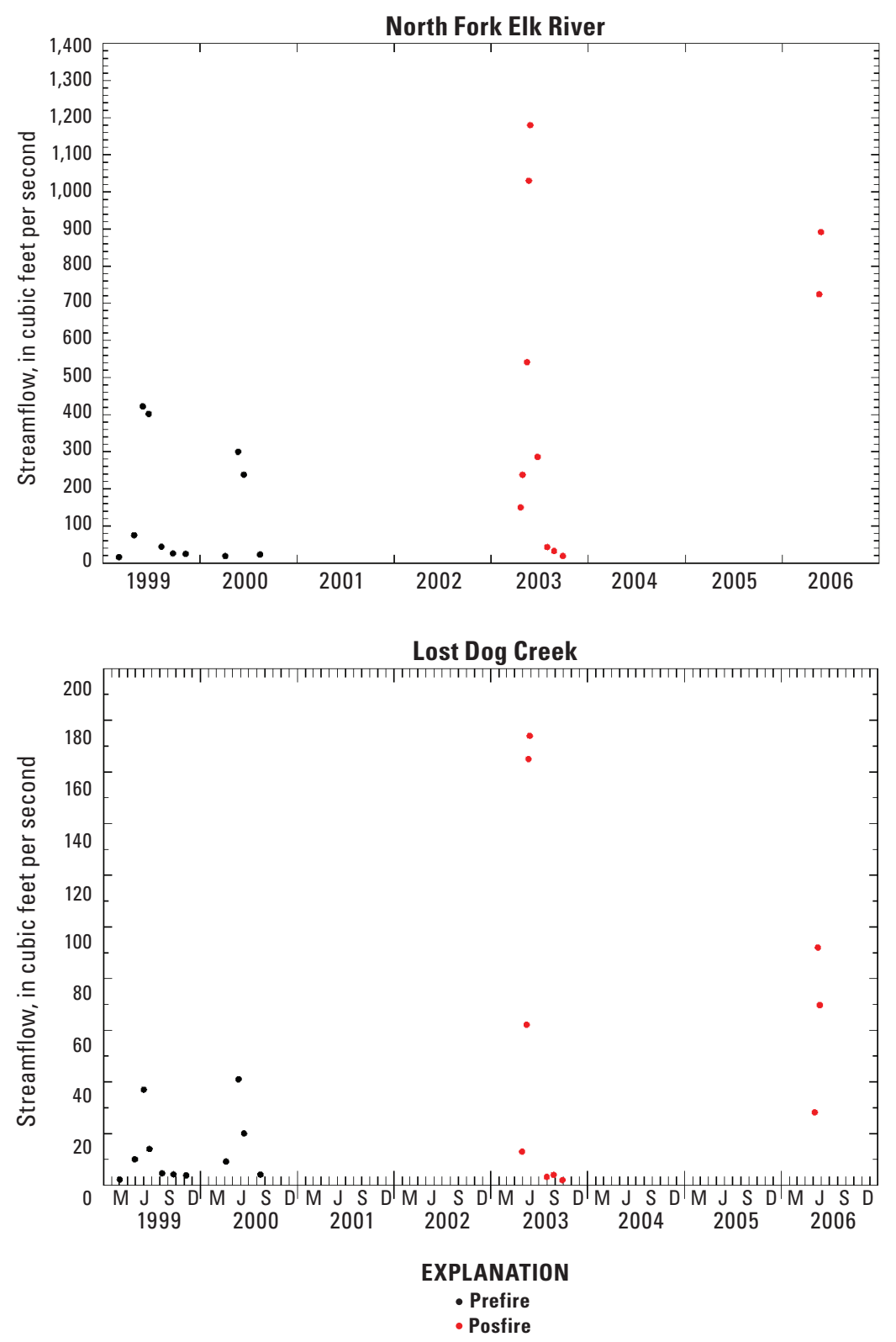

Figure 21. Graphs showing instantaneous streamflow measured during water-quality sampling at North Fork Elk River and Lost Dog Creek, 1999-2006.

precipitation to form a soil solution with a typically moderate to high pH (Ceam and others, 2004; Certini, 2005). Surface runoff and leaching to groundwater are the likely pathways for transport of the fire-produced major ions to streams, in addition to direct, dry atmospheric deposition on open water, both during the fire and as ash mobilized by postfire winds.

The effects of fire on major-ion chemistry in the Hayman study area were consistent with the major-ion release studies. For example, median calcium concentrations and median calcium instantaneous loads in Fourmile were $20.3 \mathrm{mg} / \mathrm{L}$ and 220 pounds per day (lbs/d) compared to $14.9 \mathrm{mg} / \mathrm{L}$ and 45.6 (lbs/d) in Pine (appendix 2). Rainstorm runoff sampled in Fourmile (about three storms per year 2003-2006, none sampled in 2007) contained the highest concentrations of major ions in comparison to other nonstorm Hayman fire water-quality samples collected during the study. Rainstorm runoff at Pine never occurred when storm sampling was done at Fourmile, however, so comparison between storm-affected samples of burned and unburned storm runoff could not be done. Storms are often intense and brief, but most constituent loads are likely transported during the more sustained high streamflows that occur during snowmelt. For nonstorm water-quality samples, comparisons of paired specific-conductance and major-ion data using the Wilcoxon signed-rank test indicated that specific conductance, concentrations of all major ions (except for acidneutralizing capacity), and drainage-area-normalized loads of 


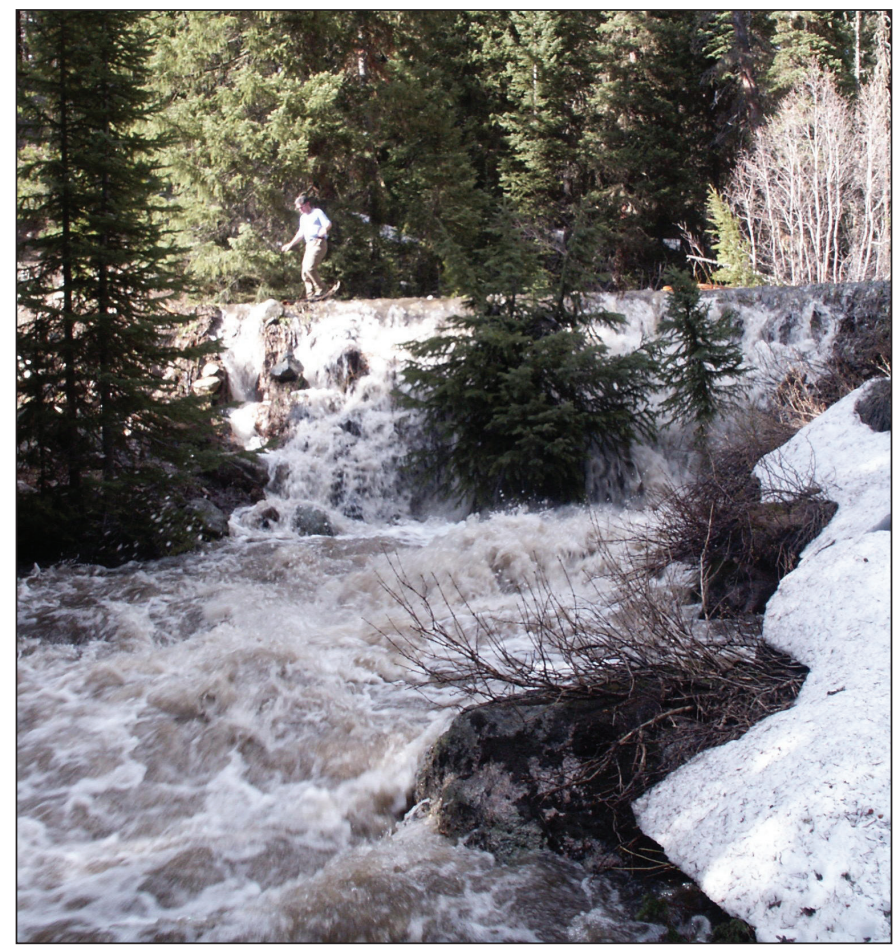

Figure 22. Photograph showing flooding from snowmelt runoff on May 29, 2003 (post-Hinman fire), showing creek overtopping Forest Service road at 174 cubic feet per second in the 3.2 squaremile watershed of Lost Dog Creek.

major ions are all greater in Fourmile ( $p$-value $<0.10$ ) compared to Pine (table 3 ). Sources of the larger concentrations and loads are major-ion oxides released from plant tissue and soils by pyrolysis that are soluble in precipitation (Bitner and others, 2001) and increased weathering of rock and minerals made unstable by soil heating (Blackwelder, 1926).

\section{Nutrients and Organic Carbon}

Nitrogen, phosphorus, and organic compounds in water are essential nutrients for aquatic phytoplankton (algae) and bacteria. In high concentrations, however, nutrients can produce a nuisance growth of algae in streams, lakes, and reservoirs. Fire volatilizes much of the nitrogen in combusted forest canopy (Certini, 2005; Anderson, 2002). Organic nitrogen in partly or moderately burned biomass and soil organic matter is transformed by pyrolysis into the inorganic form, ammonia. Nitrification processes in soil convert much of the ammonia into nitrite and, ultimately, nitrate (Certini, 2005; Anderson, 2002). Burning may produce additional nitrogen release from biomass and soil in areas saturated by nitrogen from atmospheric deposition (Meixner and others, 2006).

Phosphorus is not volatilized easily in a wildfire and, similar to nitrogen, is transformed during combustion of biomass to more biologically available forms (Ranalli, 2004). Organic phosphorus is converted to the inorganic form, orthophosphorus, by pyrolysis (Ceam and others, 2004). This mineralized, plant-available form can be leached from ash and heated soil and transported to streams if surface runoff occurs. However, when infiltration of the orthophosphorus to the soil profile occurs, this available form is generally readily immobilized by soil iron and aluminum oxides or calcium, preventing release to streams (Certini, 2005). Phosphorus that is adsorbed to soil or in organic form often accounts for a large proportion of the total phosphorus in sediment-laden postfire runoff.

Summary water-quality statistics for nitrogen, phosphorus, and organic carbon are listed in appendix 2 . The median of the nutrient concentrations and loads of total ammonia plus organic nitrogen, ammonia, nitrite plus nitrate, total phosphorus, orthophosphorus, and total organic carbon were larger in Fourmile than in Pine (figs. 24 and 25). For example, median nitrate concentrations and loads in Fourmile were $0.538 \mathrm{mg} / \mathrm{L}$ (4.61 lbs/d), and were $0.097 \mathrm{mg} / \mathrm{L}(0.349 \mathrm{lb} / \mathrm{d})$ in Pine.

For nonstorm samples, comparisons of paired nutrient and carbon concentrations and loads in the streams using the Wilcoxon signed-rank test indicated larger concentrations and larger drainage-area-normalized loads in Fourmile ( $p$-value $<0.10$ ) than in Pine for nitrite, nitrite plus nitrate, total ammonia plus organic nitrogen, total and dissolved phosphorus, and orthophosphorus (table 3). Dissolved nitrite plus nitrate and orthophosphorus concentrations were generally an order of magnitude larger in the first year postfire runoff (2003) collected from Fourmile than in samples collected from Pine (fig. 26). Similarly, total ammonia plus organic nitrogen and total phosphorus concentrations were generally one to three orders of magnitude larger in the first-year postfire runoff (2003) collected from Fourmile than in samples collected from Pine (fig. 26). Nitrite plus nitrate showed decreased seasonal variability after the first year but an increase in low-flow concentrations and loads after 2003 (figs. 26 and 27) at Fourmile but not at Pine.

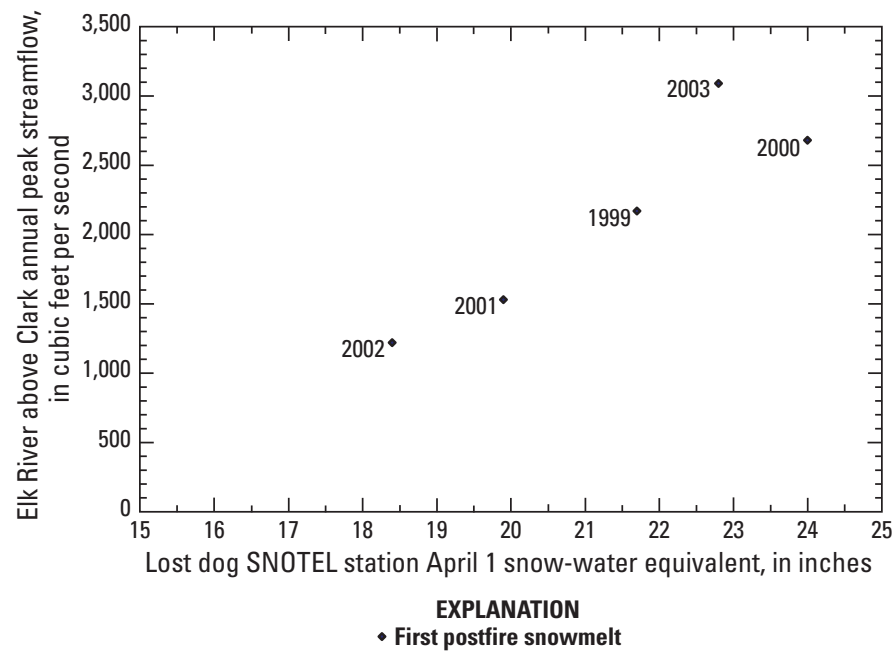

Figure 23. Graph showing relation of annual peak streamflow (instantaneous) with snow-water equivalent (April 1) at Elk River above Clark, 1999 through 2003. 

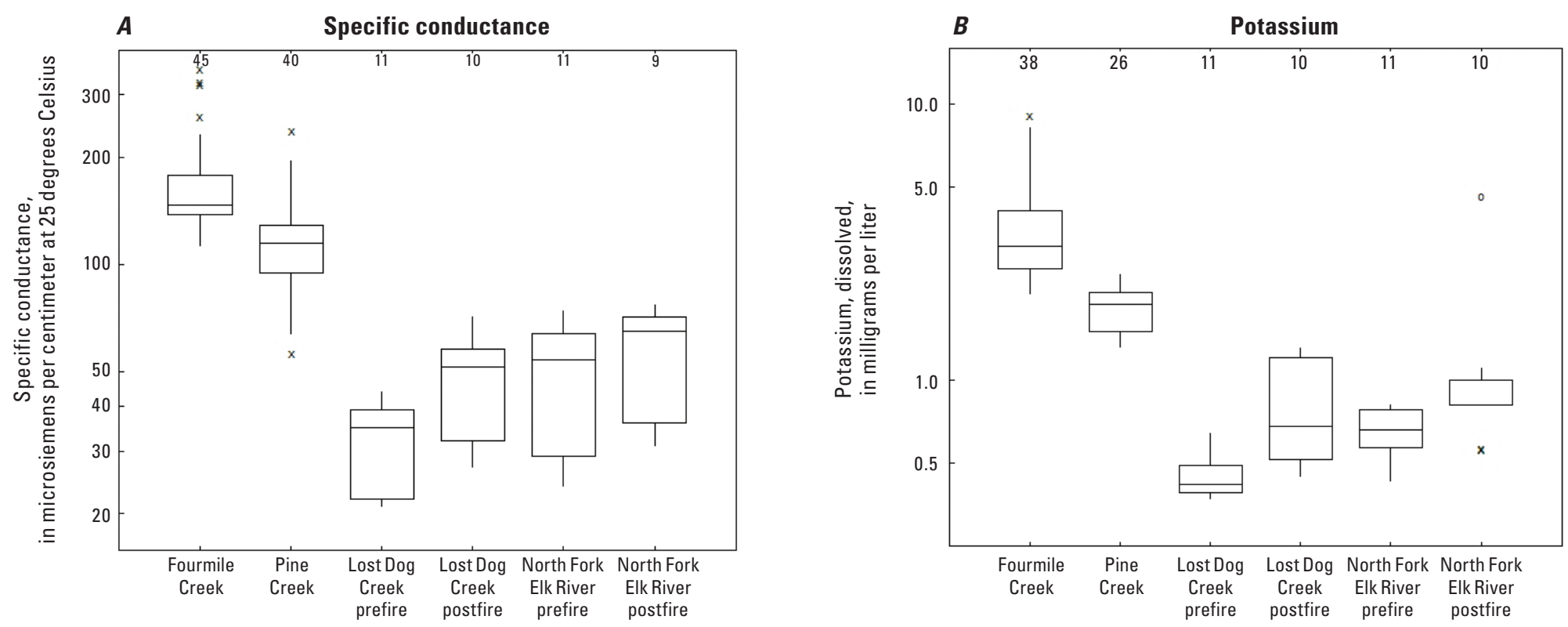

EXPLANATION

Schematic boxplot

30 Number of values

- Upper detached

$\times$ Upper outside

Upper adjacent

75th percentile

Median

25th percentile

Lower adjacent

$\times$ Lower outside

Lower detached
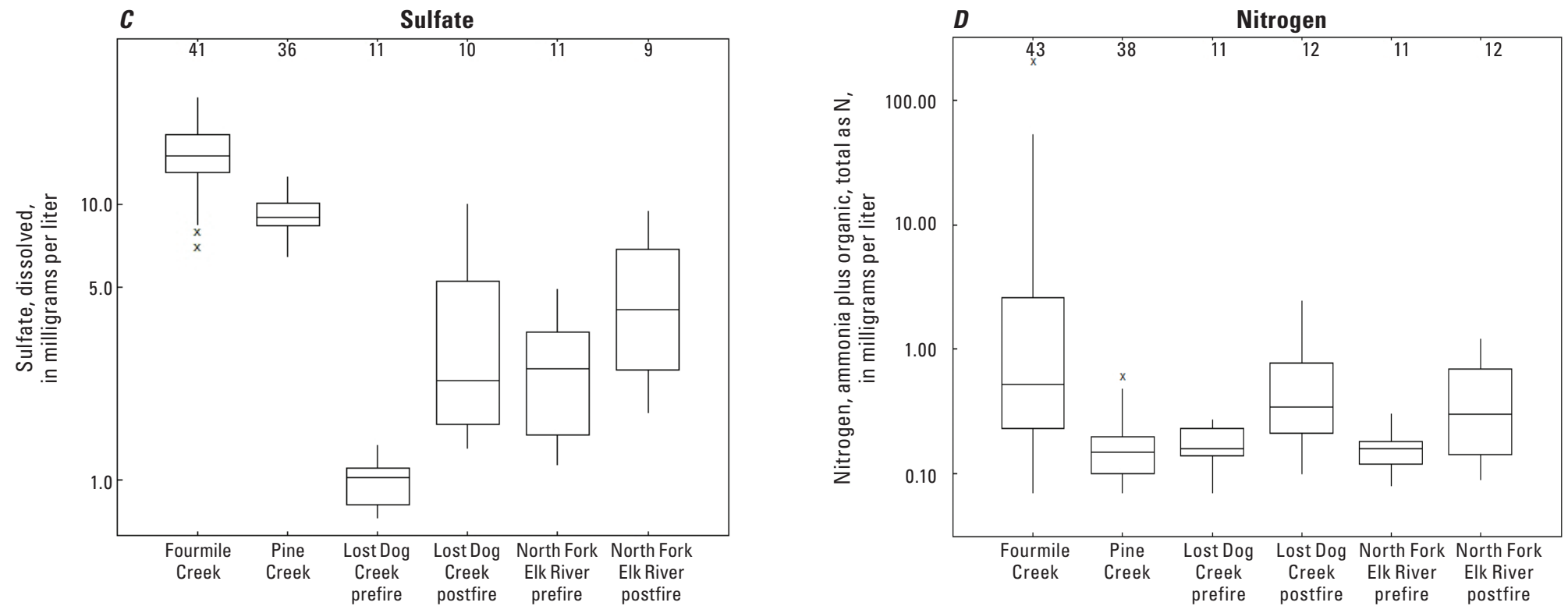

Figure 24. Boxplots showing distribution of concentrations of selected water-quality constituents at Fourmile Creek, Pine Creek, Lost Dog Creek, and North Fork Elk River, 1999-2007. 

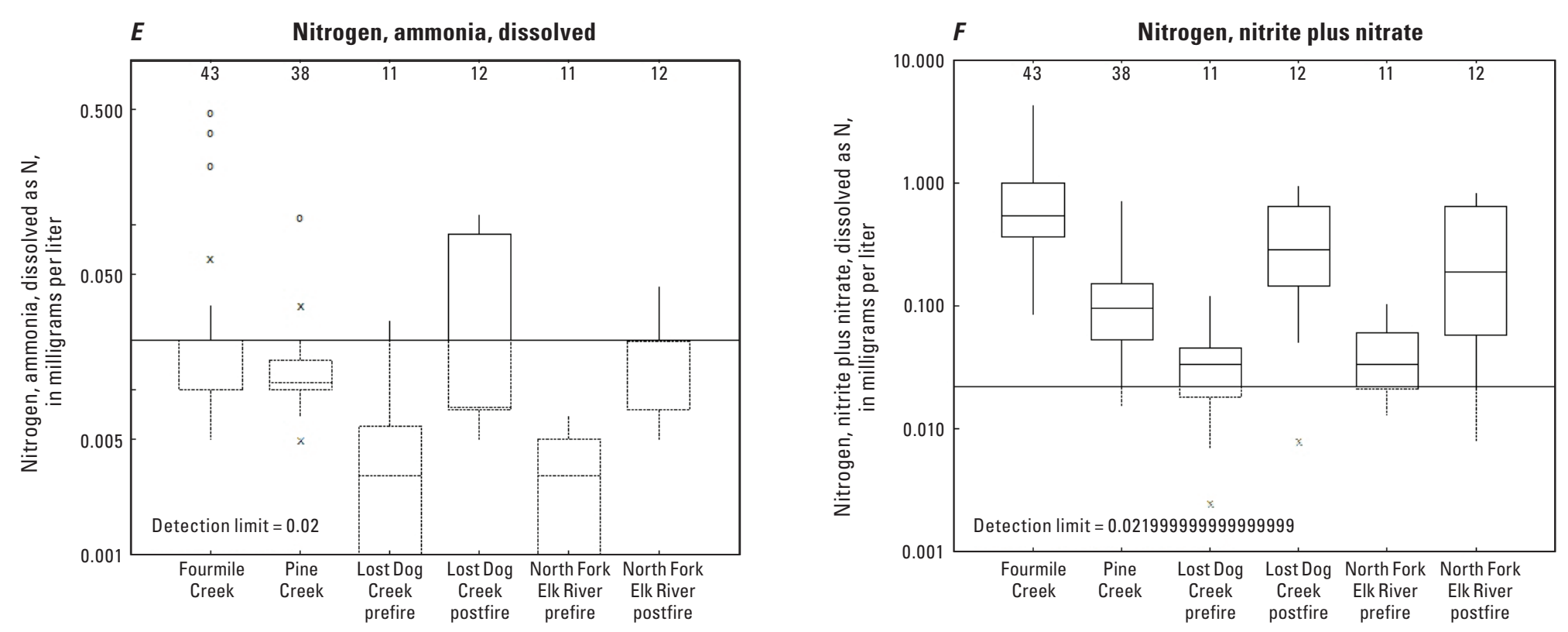

EXPLANATION

Schematic boxplot

30 Number of values

- Upper detached

$x$ Upper outside

Upper adjacent

75 th percentile

Median

25th percentile

Lower adjacent

Lower outside
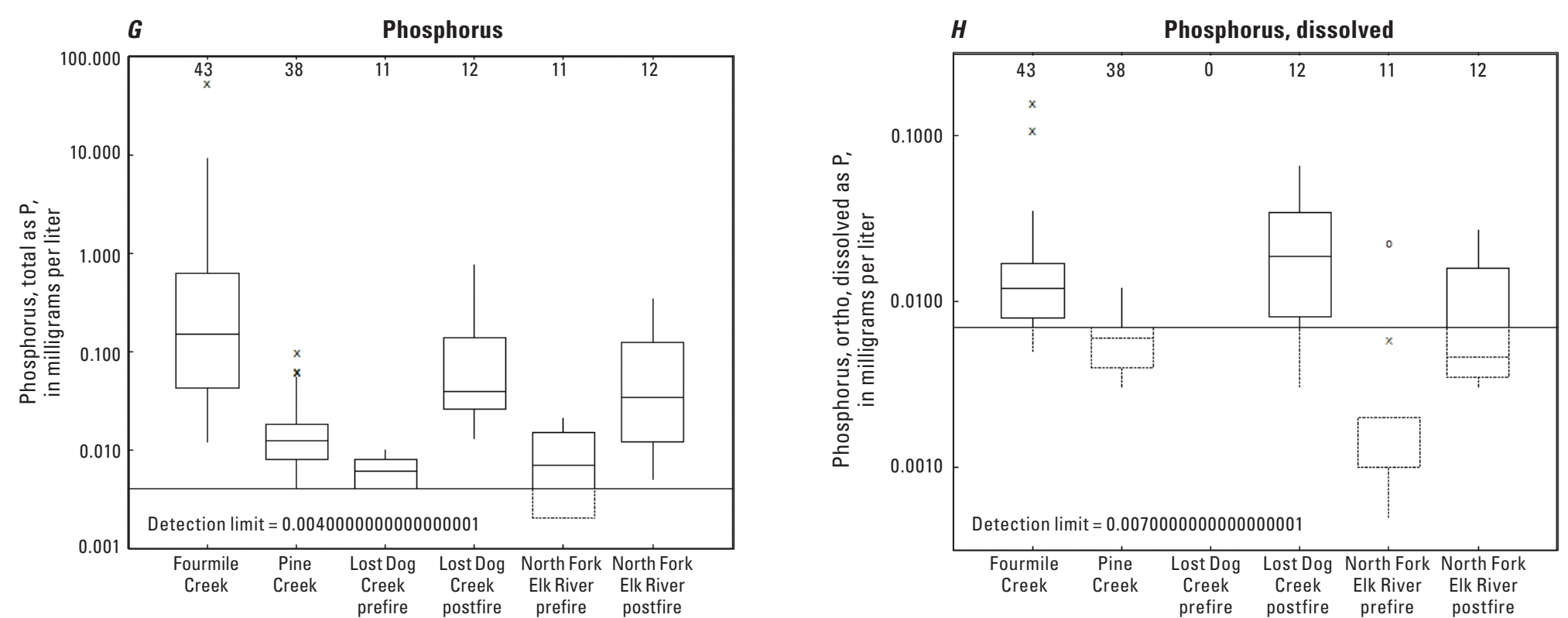

Figure 24. Boxplots showing distribution of concentrations of selected water-quality constituents at Fourmile Creek, Pine Creek, Lost Dog Creek, and North Fork Elk River, $1999-2007$. -Continued 

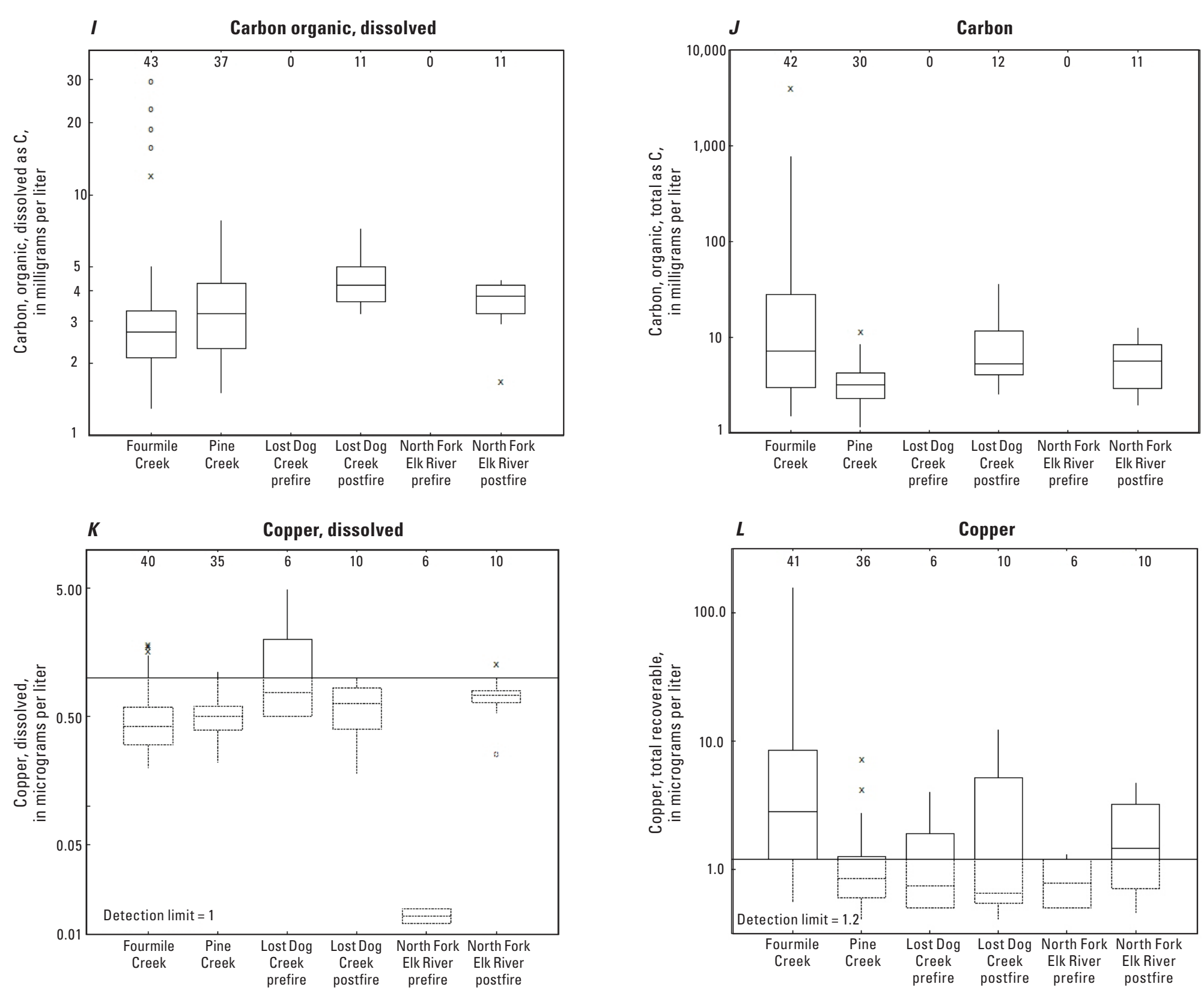

Figure 24. Boxplots showing distribution of concentrations of selected water-quality constituents at Fourmile Creek, Pine Creek, Lost Dog Creek, and North Fork Elk River, $1999-2007$. -Continued

ATION

Schematic boxplot

30 Number of values

Upper detached

Upper outside

Upper adjacent

75th percentile

Median

25th percentile

Lower adjacent

Lower outside

Lower detached 

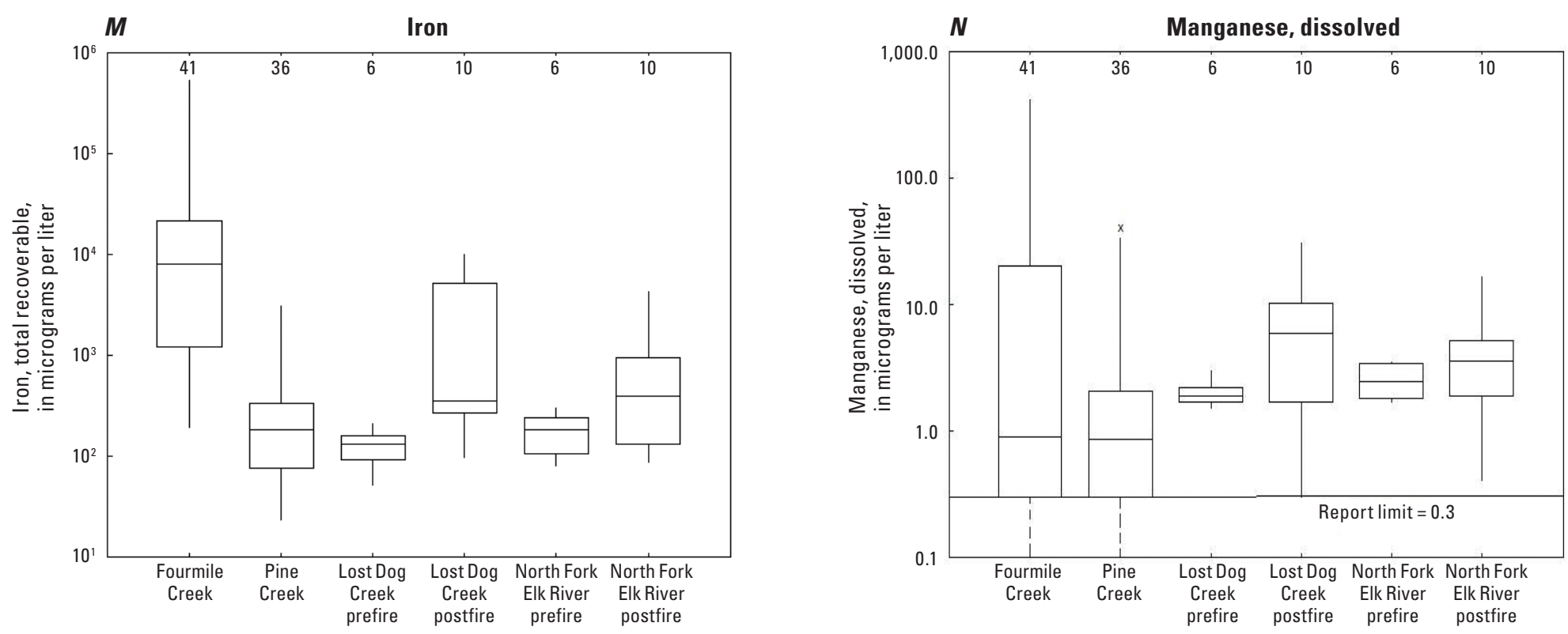

EXPLANATION

Schematic boxplot

30 Number of values

- Upper detached

$x$ Upper outside

Upper adjacent

75th percentile

Median

25th percentile

Lower adjacent

$x$ Lower outside

- Lower detached
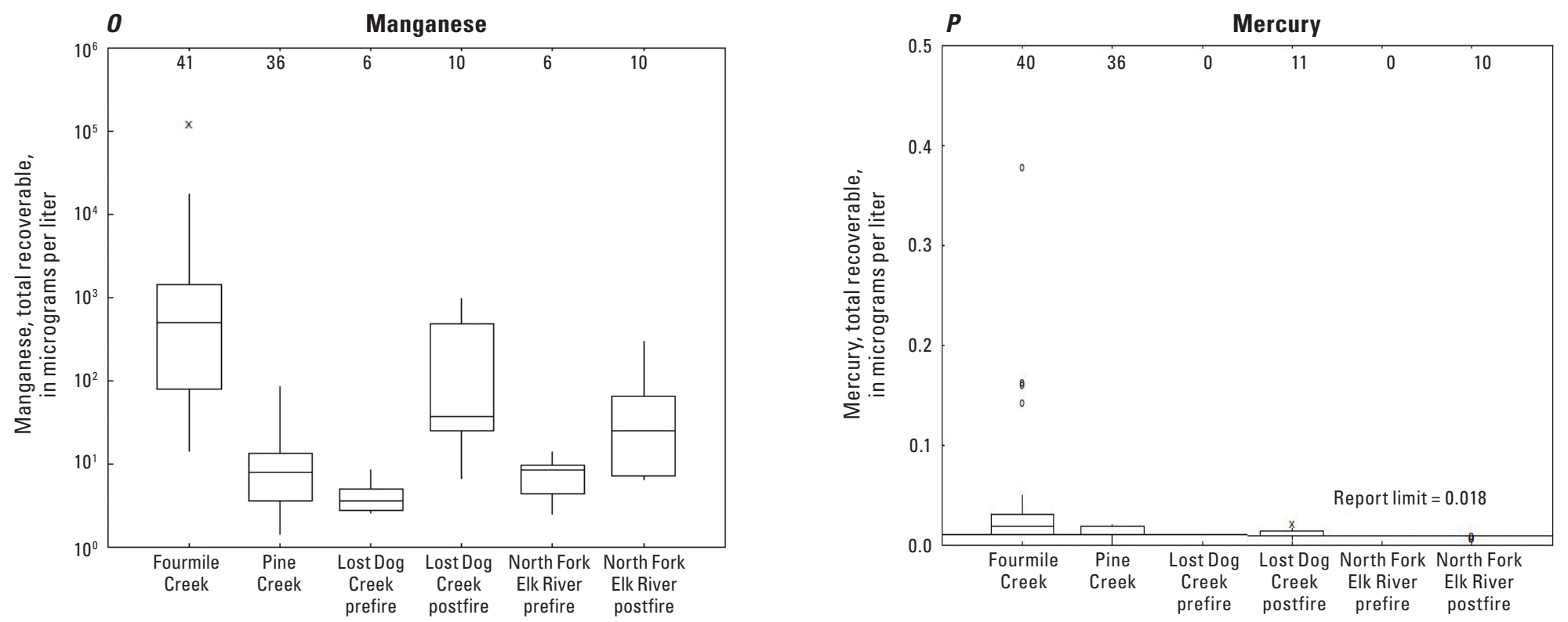

Figure 24. Boxplots showing distribution of concentrations of selected water-quality constituents at Fourmile Creek, Pine Creek, Lost Dog Creek, and North Fork Elk River, $1999-2007$. -Continued 

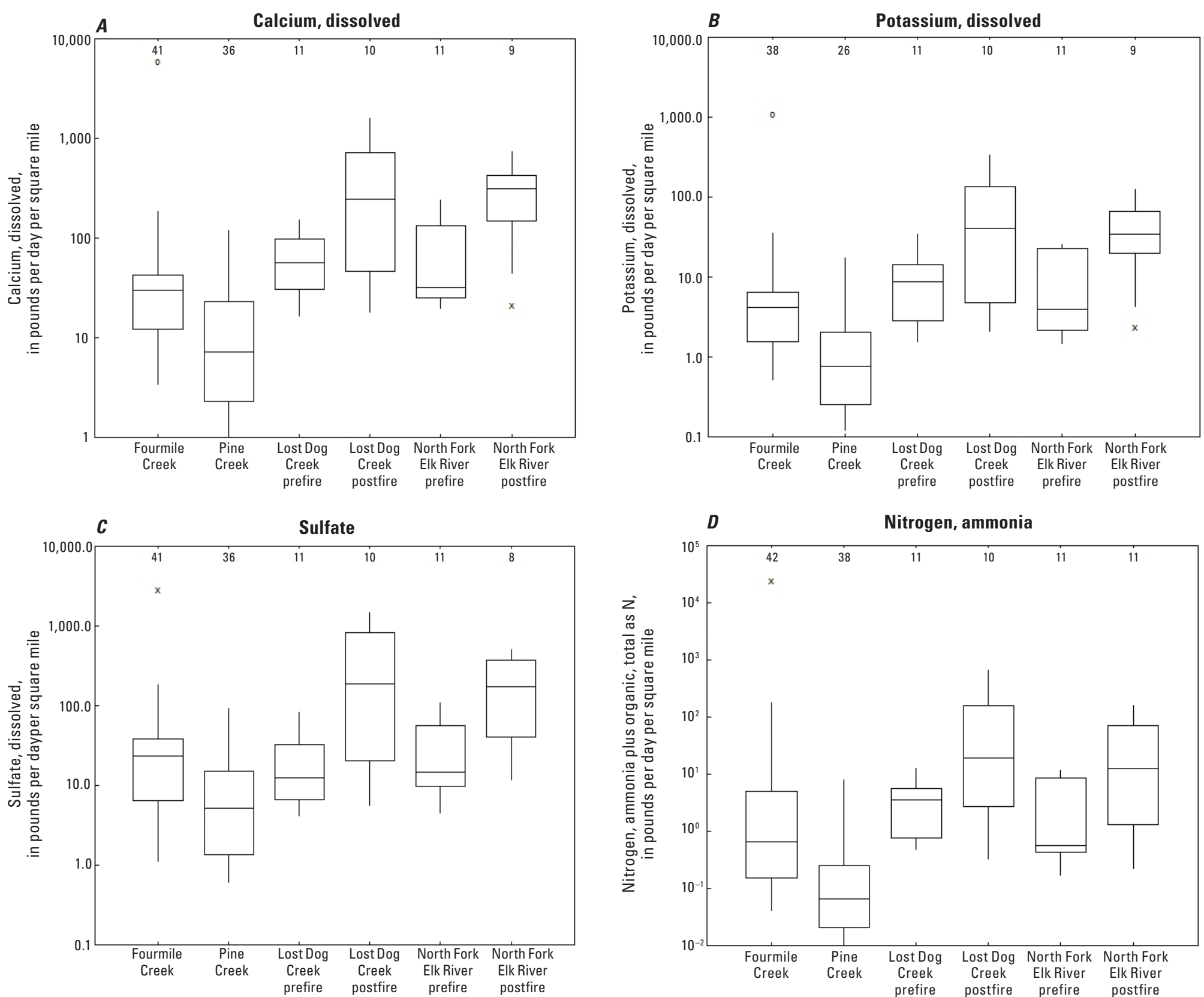

Figure 25. Boxplots showing distribution of loads normalized to drainage area for selected water-quality constituents at Fourmile Creek, Pine Creek, Lost Dog Creek, and North Fork Elk River, 1999-2007.

EXPLANATION

Schematic boxplot

30 Number of values

- Upper detached

$x$ Upper outside

Upper adjacent

75th percentile

Median

25th percentile

Lower adjacent

$x$ Lower outside

- Lower detached 

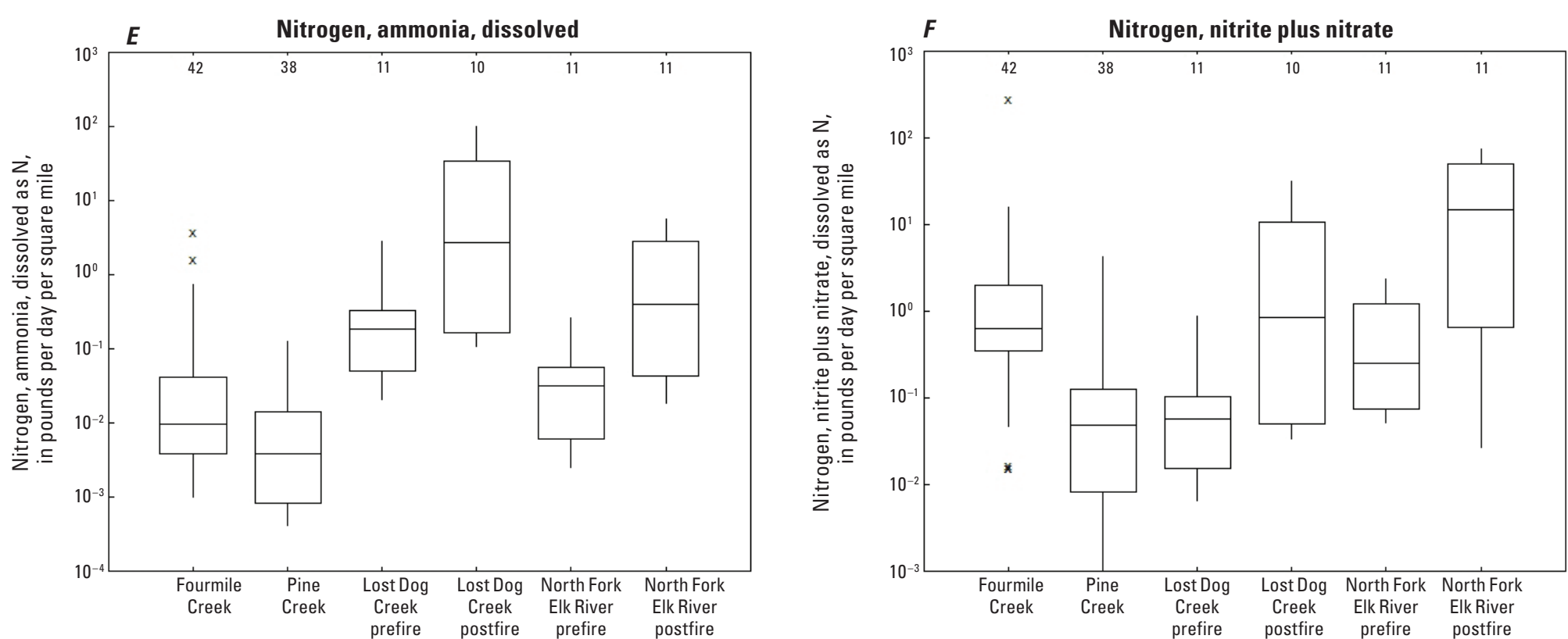

\section{EXPLANATION}

Schematic boxplot

30 Number of values

- Upper detached

Upper outside

Upper adjacent

75th percentile

Median

25th percentile

Lower adjacent

Lower outside

Lower detached
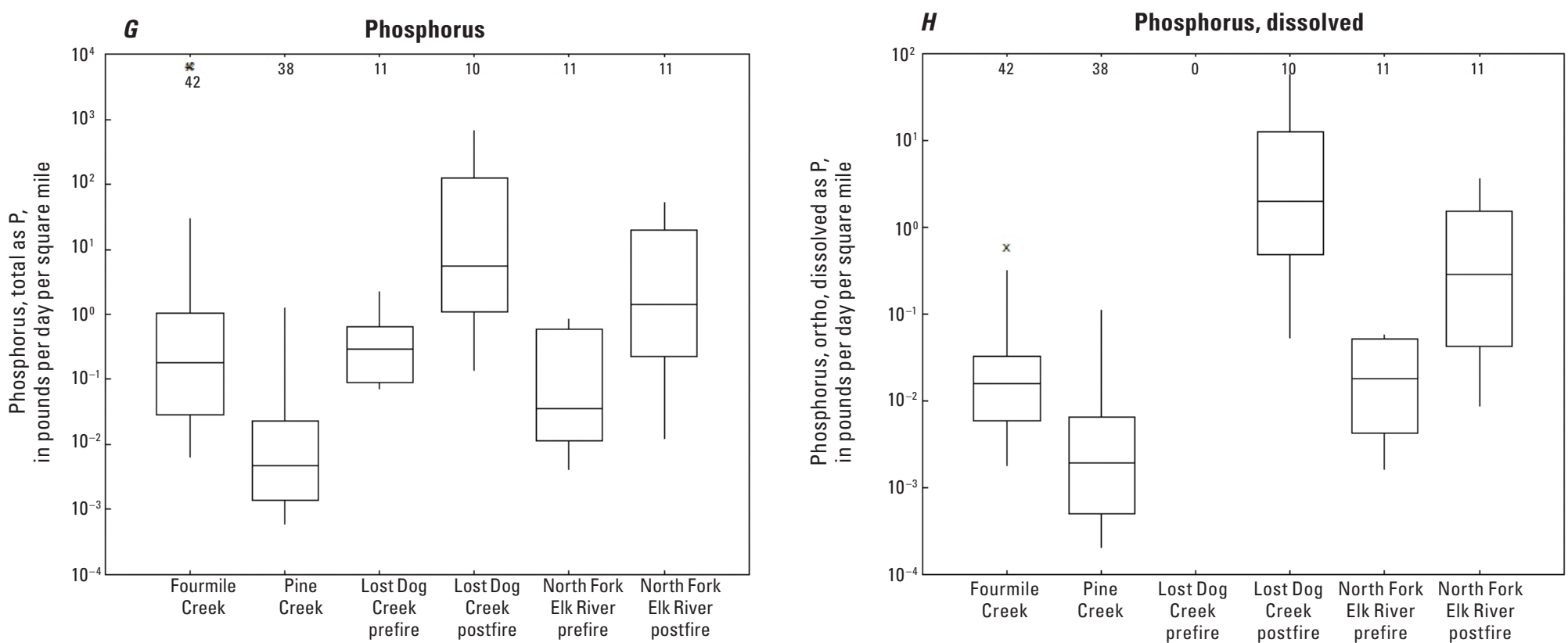

Figure 25. Boxplots showing distribution of loads normalized to drainage area for selected water-quality constituents at Fourmile Creek, Pine Creek, Lost Dog Creek, and North Fork Elk River, 1999-2007.-Continued 

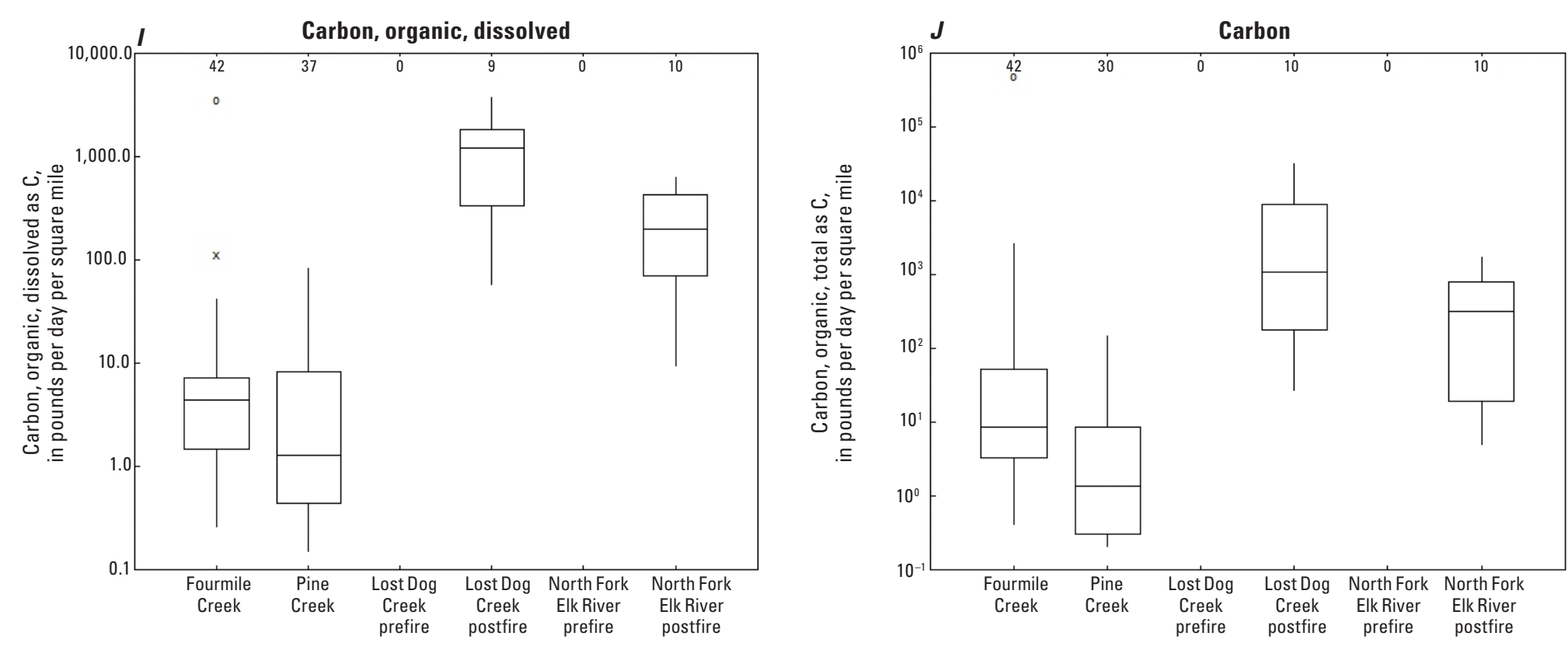

EXPLANATION

Schematic boxplot

30 Number of value

- Upper detached

Upper outside

Upper adjacent

75th percentile

Median

25th percentile

Lower adjacent

x Lower outside

- Lower detached
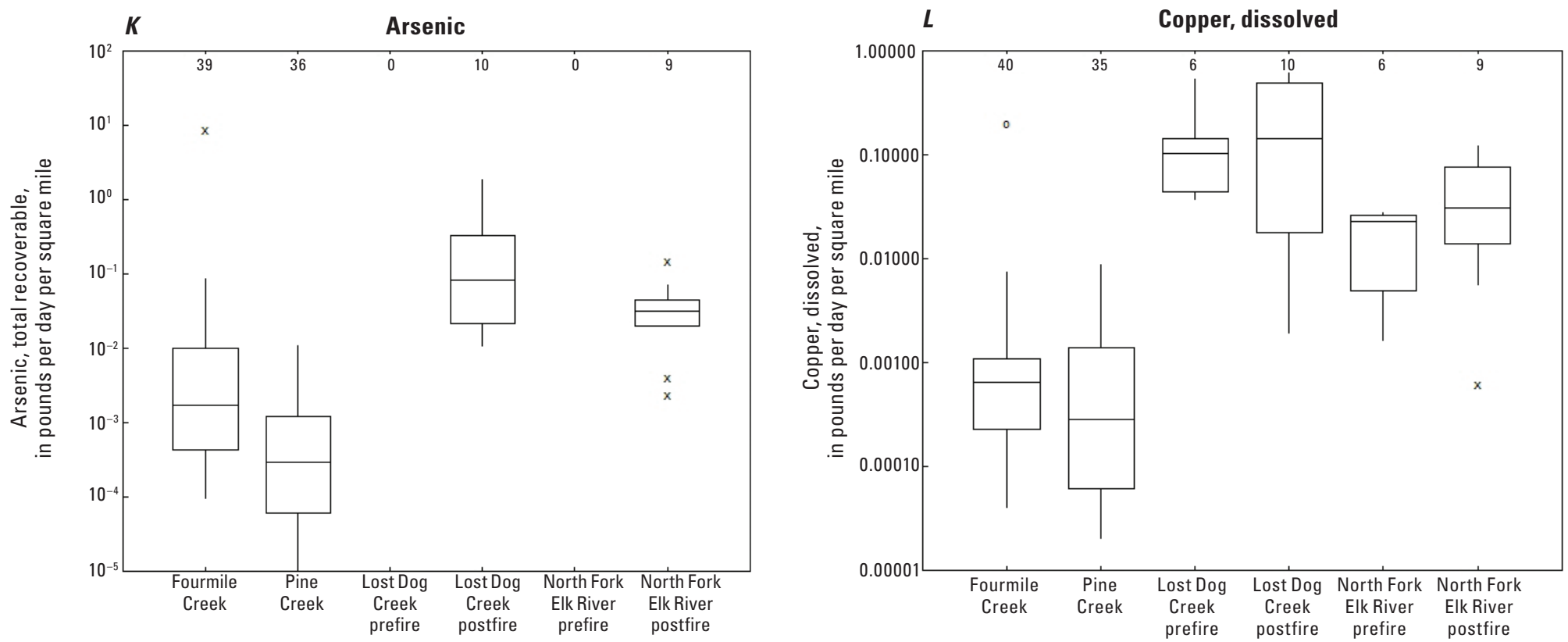

Figure 25. Boxplots showing distribution of loads normalized to drainage area for selected water-quality constituents at Fourmile Creek, Pine Creek, Lost Dog Creek, and North Fork Elk River, 1999-2007.-Continued 

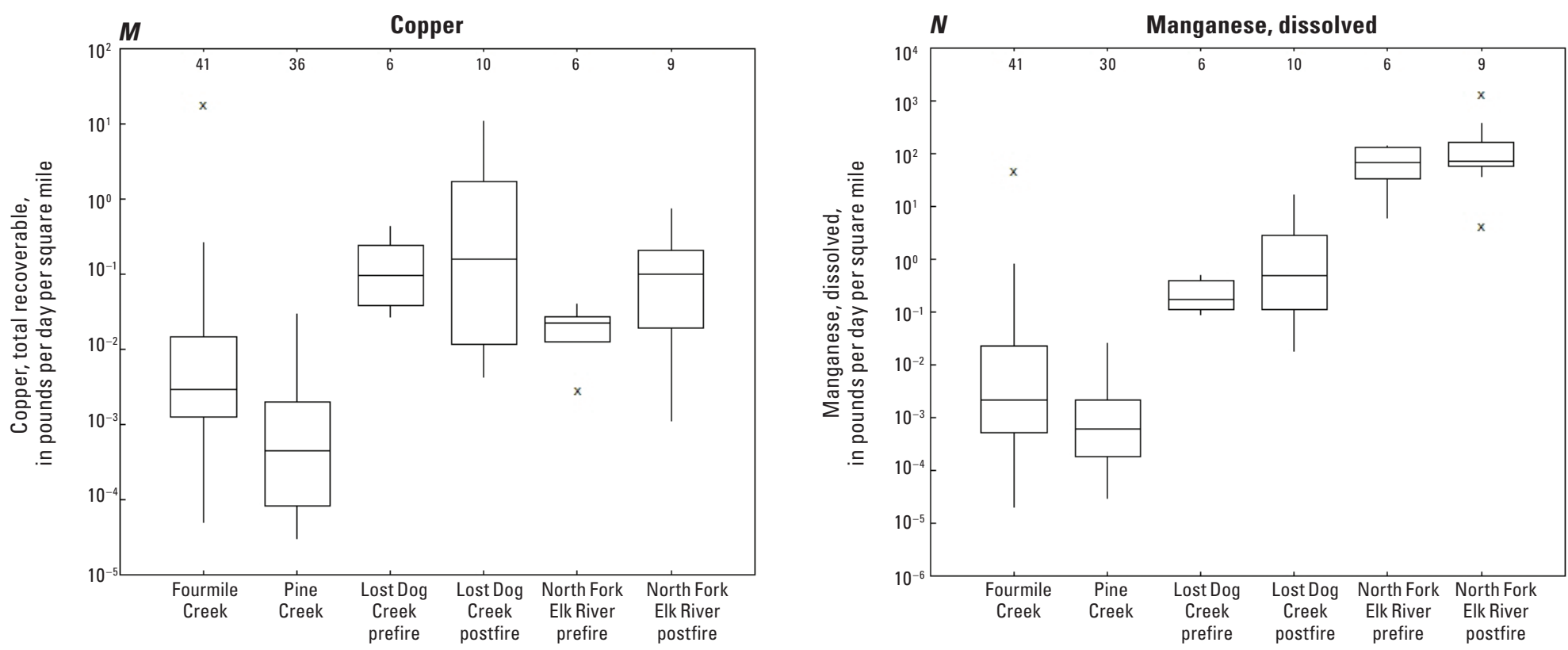

EXPLANATION

Schematic boxplot

30 Number of values

- Upper detached

Upper outside

Upper adjacent

75th percentile

Median

25th percentile

Lower adjacent

Lower outside

- Lower detached
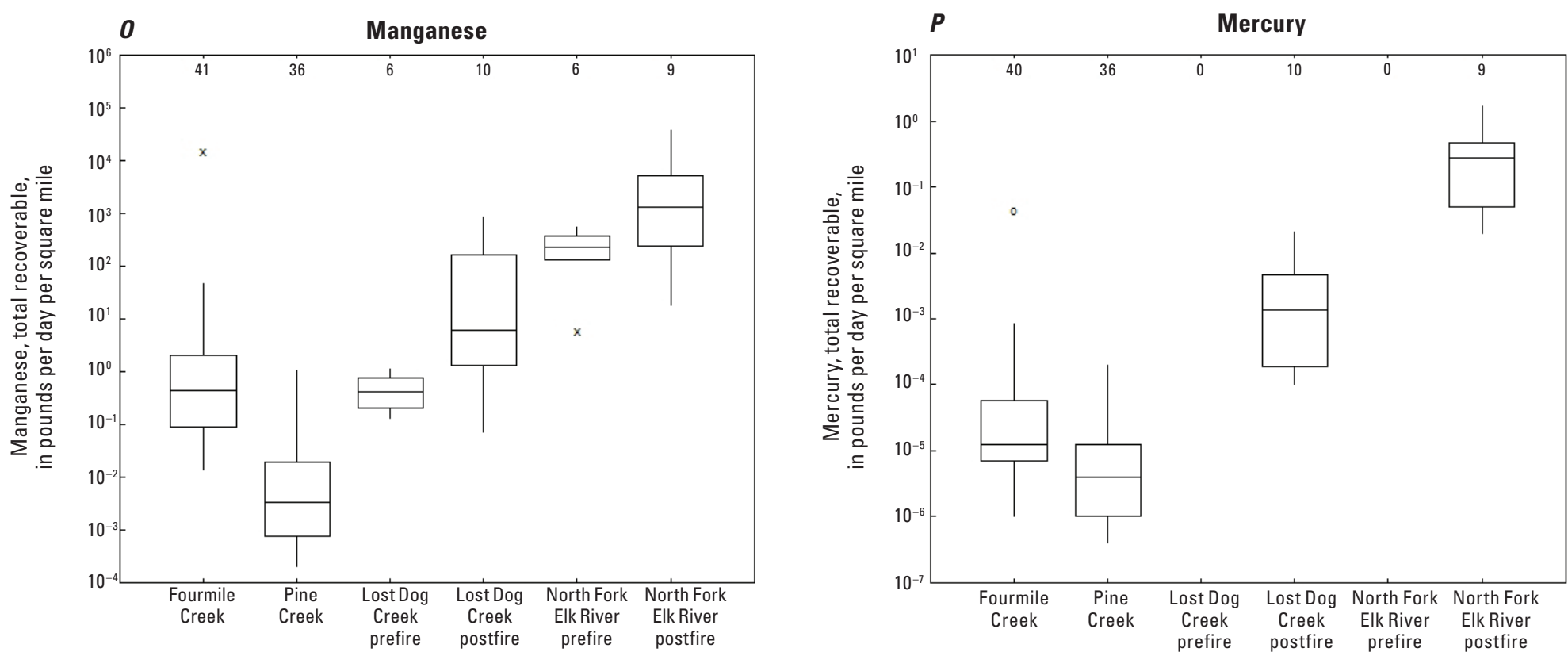

Figure 25. Boxplots showing distribution of loads normalized to drainage area for selected water-quality constituents at Fourmile Creek, Pine Creek, Lost Dog Creek, and North Fork Elk River, 1999-2007.-Continued 

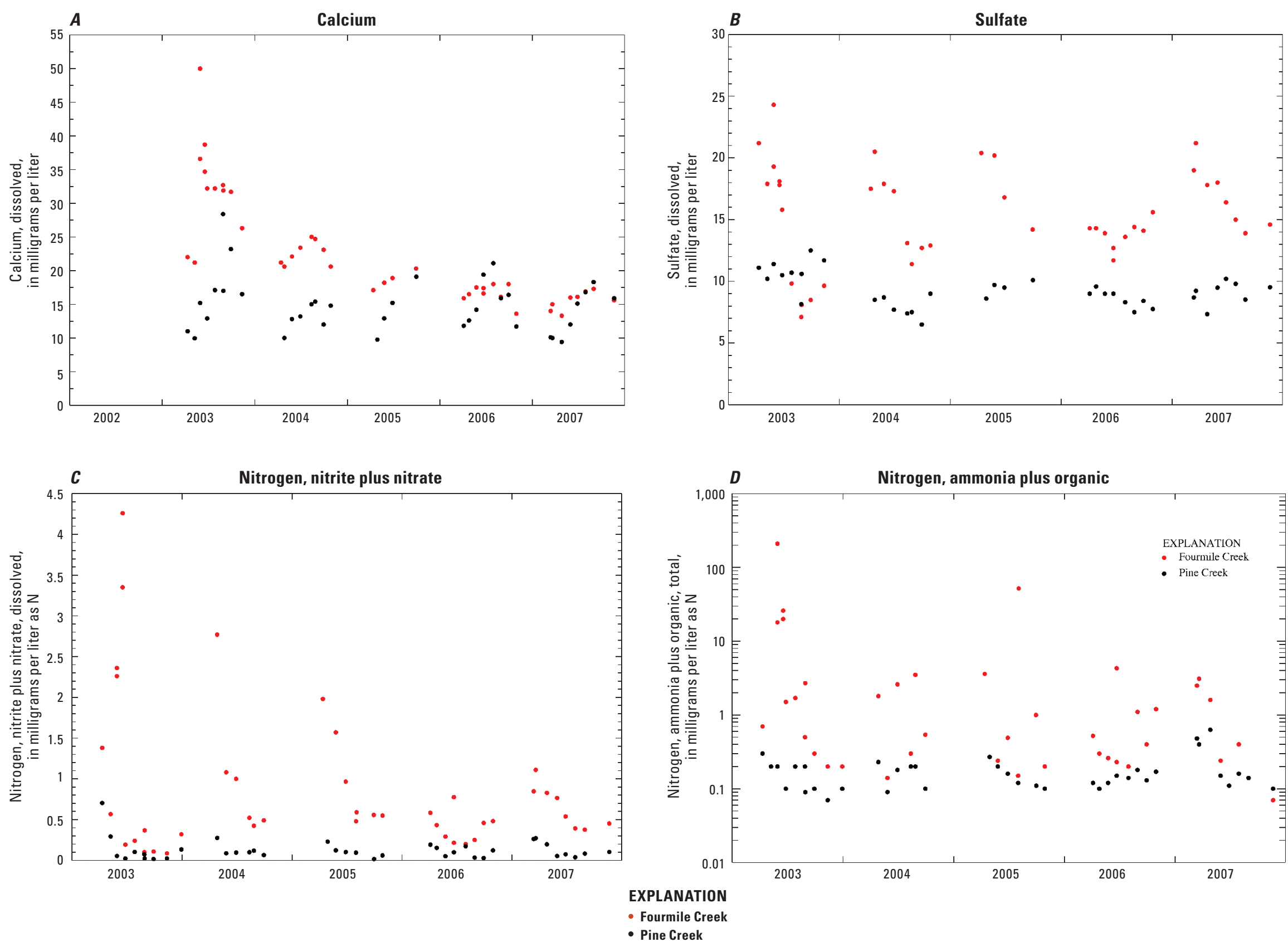

Figure 26. Graphs showing concentrations of selected water-quality constituents at Fourmile Creek (burned) and Pine Creek (unburned), Colorado, $2003-2007$. 

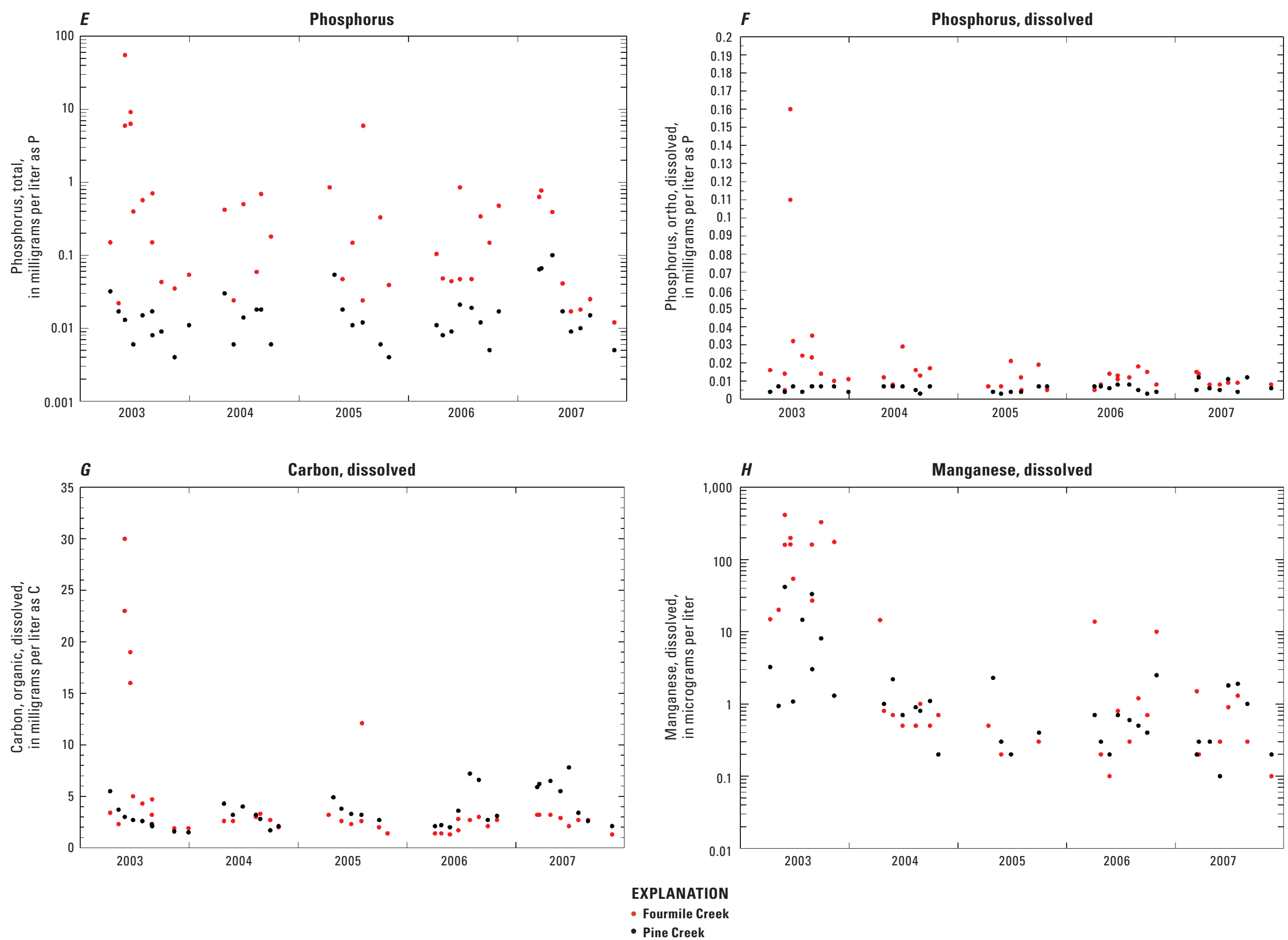

Figure 26. Graphs showing concentrations of selected water-quality constituents at Fourmile Creek (burned) and Pine Creek (unburned), Colorado, 2003-2007.-Continued 

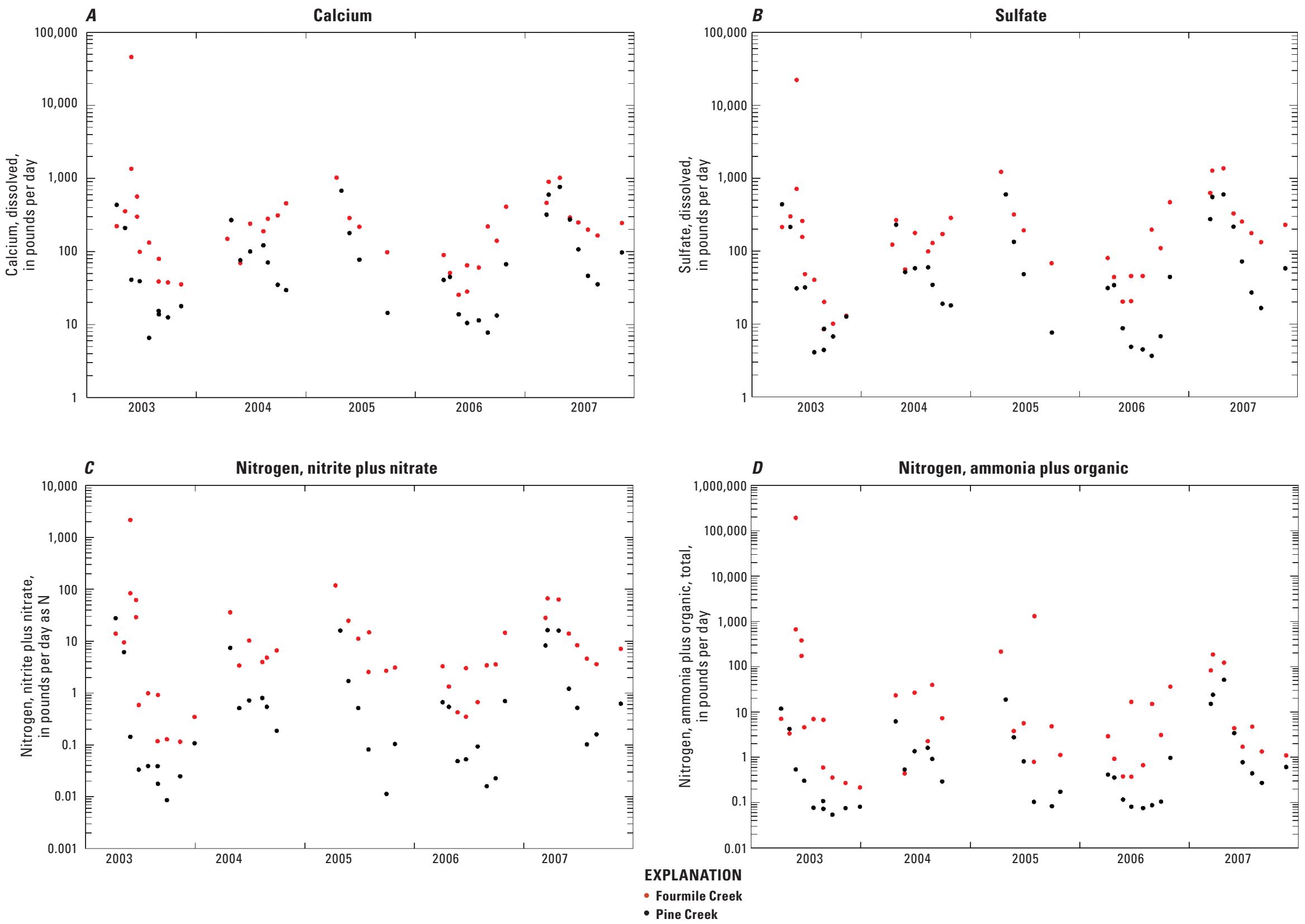

Figure 27. Graphs showing instantaneous loads of selected water-quality constituents at Fourmile Creek (burned) and Pine Creek (unburned), Colorado, $2003-2007$. 

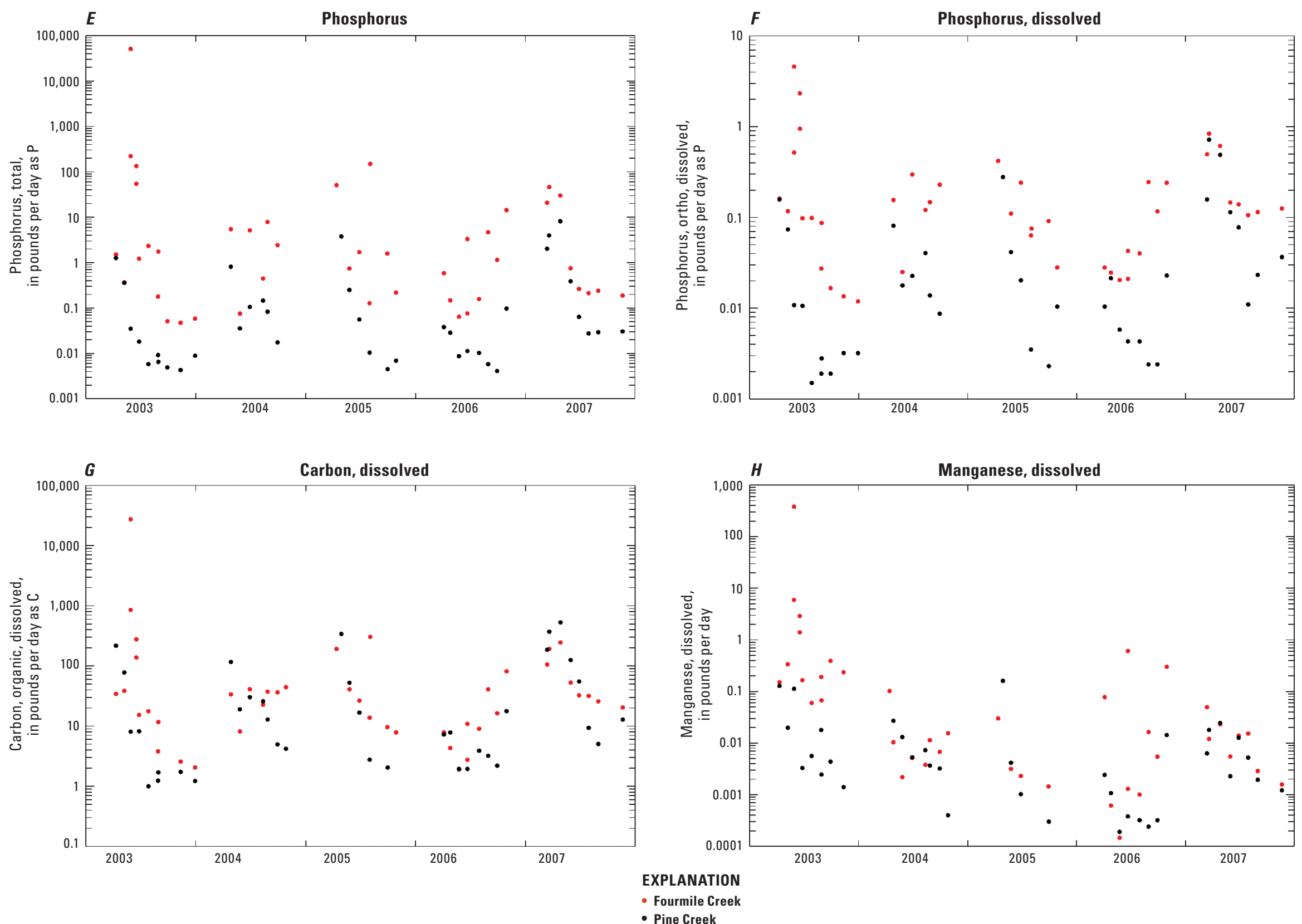

Figure 27. Graphs showing instantaneous loads of selected water-quality constituents at Fourmile Creek (burned) and Pine Creek (unburned), Colorado, 2003-2007.-Continued 
Concentrations of nitrite plus nitrate during 2003 storm runoff samples at Fourmile ranged from 2.26 to $4.26 \mathrm{mg} / \mathrm{L}$ (appendix 1). High postfire concentrations of nitrate are usually attributed to mineralization of organic matter (Choromanska and DeLuca, 2002; Ranalli, 2004) and is most likely the cause of high concentrations in Fourmile as well. These higher rainfall runoff concentrations of nitrite plus nitrate are usually explained by increased nitrogen mineralization, but also might be partially explained by an abbreviated postfire flow path that reduces precipitation contact with the soil profile. Overland flow due to water repellency or forest floor and canopy loss could prevent nutrient attenuation by bacteria and rooted vegetation in soils. Runoff of precipitation with its relatively high concentrations of dissolved inorganic nitrogen may contribute to larger stream concentrations of nitrogen in addition to the input processes generally attributed to the biogeochemical transformations caused by burning. Sulfate concentrations also may be increased by surface runoff that bypasses soil attenuation processes in postfire conditions.

Concentrations of ammonia plus organic nitrogen (total as N) (range 0.07 to $210 \mathrm{mg} / \mathrm{L}$ ) and total phosphorus ( 0.012 to $55.2 \mathrm{mg} / \mathrm{L}$ ) in Fourmile were generally larger in snowmelt and rainstorm samples compared to concentrations in Pine (total ammonia plus organic nitrogen ranged from 0.07 to $0.63 \mathrm{mg} / \mathrm{L}$ ) (total phosphorus ranged from 0.004 to $0.066 \mathrm{mg} / \mathrm{L}$ ). The high concentrations in Fourmile were related to abundant particulate organic matter in the hillslope runoff and stream channel erosion. Particulate organic nitrogen and particulate-related phosphorus concentrations (indicated by large concentration differences between filtered and unfiltered samples) were large and accounted for most of the nutrient loads.

Although dissolved nitrite plus nitrate and ammonia and dissolved phosphorus and orthophosphorus were generally a small proportion of the total nitrogen and phosphorus loads in peak streamflow, the loads from the burned Fourmile watershed were large compared to loads in the unburned Pine watershed, especially in 2003 (fig. 27). In 2003, large accumulations of periphyton and macrophytes observed in Fourmile and the South Platte River downstream from Deckers (fig. 28) seem to indicate that postfire nutrients were available to stimulate growth. Bioavailable forms of nitrogen and phosphorus such as nitrite plus nitrate, ammonia, and orthophosphorus may cause initial eutrophic responses in receiving waters, but high turbidity may limit the initial response to the increase in nutrients due to light limitation (Allen, 1995). Less bioavailable forms of nutrients (organic nitrogen and phosphorus adsorbed to particles) may be transported to environments where decomposition, assimilation, or redox transformations may convert them to more bioavailable forms (Allen, 1995).

Similarities in nonstorm organic carbon concentrations were observed between the burned and unburned watersheds. Median DOC concentrations (2003-2007) in Fourmile $(2.7 \mathrm{mg} / \mathrm{L})$ were similar to those in the unburned Pine watershed (3.2 mg/L) (appendix 2). Despite this result, DOC concentrations in Fourmile were high in some storm runoff samples, including three storms, which had values that ranged from 12.1 to $30 \mathrm{mg} / \mathrm{L}$ (appendix 1). All other DOC concentrations (storm-related or not, were less than $5 \mathrm{mg} / \mathrm{L}$ ). Flushing of DOC in soil may be attributed to the infiltration of high-pH water derived from leaching of the postfire ash layer, which results in greater solubility of organic carbon (Ranalli, 2004). But the lack of a larger 5-year median DOC concentration in the burned watershed may be related to the long-term reduction in organic-carbon sources (vegetation and soil carbon) as a result of the fire, and because charcoal from the fire may absorb and sequester DOC (Nitschke, 2005). Unlike DOC, median TOC concentrations (2003-2007) in Fourmile $(7.1 \mathrm{mg} / \mathrm{L})$ were larger than median concentrations in the unburned Pine watershed (3.1 mg/L) (appendix 2). However, immediate postfire TOC concentrations during storms at Fourmile were large, including a maximum concentration of 4,160 mg/L on May 30, 2003 (appendix 1). The large particulate organic carbon fraction in the samples with high TOC concentrations was likely related to soil, streambed, and streambank erosion in postfire watersheds.

High concentration of DOC is a concern because chlorination of water without carbon reduction or dilution can result in exceedances of the disinfection byproduct rule guidance (accessed November 2, 2010, at http://www.epa.gov/ogwdw/ $m d b p / d b p 1 . h t m l)$ for THM precursors in finished drinking water to prevent the formation of THMs (suspected carcinogens) (Richardson and others, 2007). When the alkalinity of water is less than $60 \mathrm{mg} / \mathrm{L}$ as $\mathrm{CaCO}_{3}$, the USEPA Stage 1 guidance requires removal of 45 percent of TOC by enhanced treatment when TOC concentrations are greater than 4 but less than $8 \mathrm{mg} / \mathrm{L}$, and 35 percent for TOC concentrations greater than 2 but less than $4 \mathrm{mg} / \mathrm{L}$. TOC concentrations less than $2 \mathrm{mg} / \mathrm{L}$ are not required to have enhanced organics removal (accessed November 2, 2010, at http://www.epa.gov/ogwdw/ $m d b p / d b p 1 . h t m l)$. DOC is probably a more realistic measure of the carbon content that is likely to need special treatment for drinking water because the TOC concentrations include particulate organic matter that may not make it to the raw water intake or can be removed efficiently early in the treatment process. However, the high short-term TOC increases may still cause potential THMs problems for some watertreatment plants. USEPA Stage 2 rules now in effect require monitoring of specific THMs and haloacetic acids (HAAs) for compliance with maximum contaminant levels (accessed December 1, 2009, at http://www.epa.gov/ogwdw/disinfection/ stage2/basicinformation.html).

Reconnaissance-level sampling was done to collect samples (filtered) for analysis of potential THM formation in postfire runoff (appendix 7). From the limited reconnaissancesampling, THM-formation potential in Fourmile (mean of the three samples: $0.164 \mathrm{mg} / \mathrm{L}$ total THMs) was about the same as in Pine (mean of the two samples: $0.191 \mathrm{mg} / \mathrm{L}$ ) but was larger than additional samples from unburned watersheds in the Missionary Ridge fire area (a 2002 fire in southwestern Colorado) (mean of the four samples: $0.071 \mathrm{mg} / \mathrm{L}$ ) (Ranalli and Stevens, 2004) (appendix 7). Despite this greater THM concentration in Pine, large variation (about 40 to 80 percent difference) among the small number of samples exceeded the difference between the Fourmile and Pine concentrations 


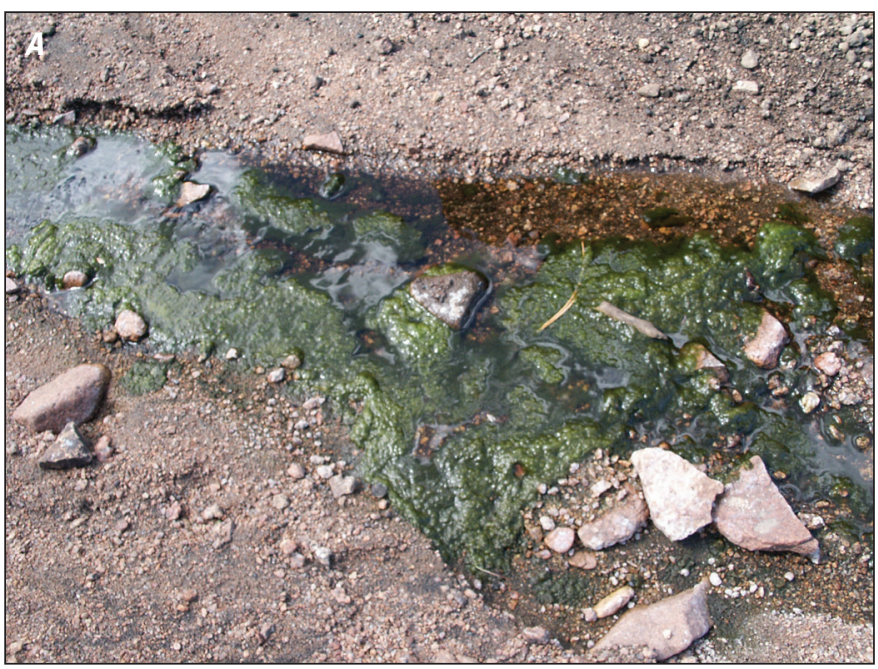

Figure 28. Photographs showing algal growth along $A$, Fourmile Creek; and $B$, South Platte River, about 4 miles north of Deckers, Colorado, during summer (2003) following the first full year after the Hayman fire.

(25 percent difference). THM results had a large degree of uncertainty due to the small number of samples. Seasonality and geographic variability are likely to affect the complex chemical composition of DOC in natural waters, resulting in variability that is not readily explained by the gross measure of organic carbon concentration (Fram and others, 1999). THM concentrations in Fourmile and Pine exceeded the USEPA maximum contaminant level of $0.08 \mathrm{mg} / \mathrm{L}$ of total THMs in drinking water (http://www.epa.gov/ogwdw/ disinfection/stage2/basicinformation.html), and thus would depend on reductions in organic carbon during treatment if diverted at these sampling sites.

Median TOC load in Fourmile was $63.2 \mathrm{lbs} / \mathrm{d}$; in Pine, the median was 8.96 (lbs/d) (appendix 2). Postfire rainstorm-runoff produced some of the largest nutrient and organic carbon concentrations in Fourmile, but paired rainstorm runoff could not be sampled in Pine.

Organic compound concentrations in runoff are known to increase during postfire runoff (Stein, 2008). In 2003, a limited number of water (seven samples from Fourmile and one sample from Pine) and bed-sediment samples (one each from Fourmile and Pine) were collected and analyzed for organic compounds (appendix 3 and 4). Many organic TICs were detected and identified by qualitative GC-MS analysis (no calibrations to specific compounds were made) of streamwater and bed sediment. Analytical results indicated a large number of TICs (appendix 3 and 4) in burned and unburned watersheds. The extreme example was a water sample collected from Fourmile during the May 30, 2003, flood that contained more than 200 organic TICs. Some of the TICs probably contribute to hydrophobicity of burned soil. Although detailed discussion of these compounds was beyond the scope of this report, analysis identified many component organic compounds of conifer resins, organic compounds formed during combustion, and compounds produced by degradation of both (Oros and others, 2002; Gonzalez-Perez and others, 2004;

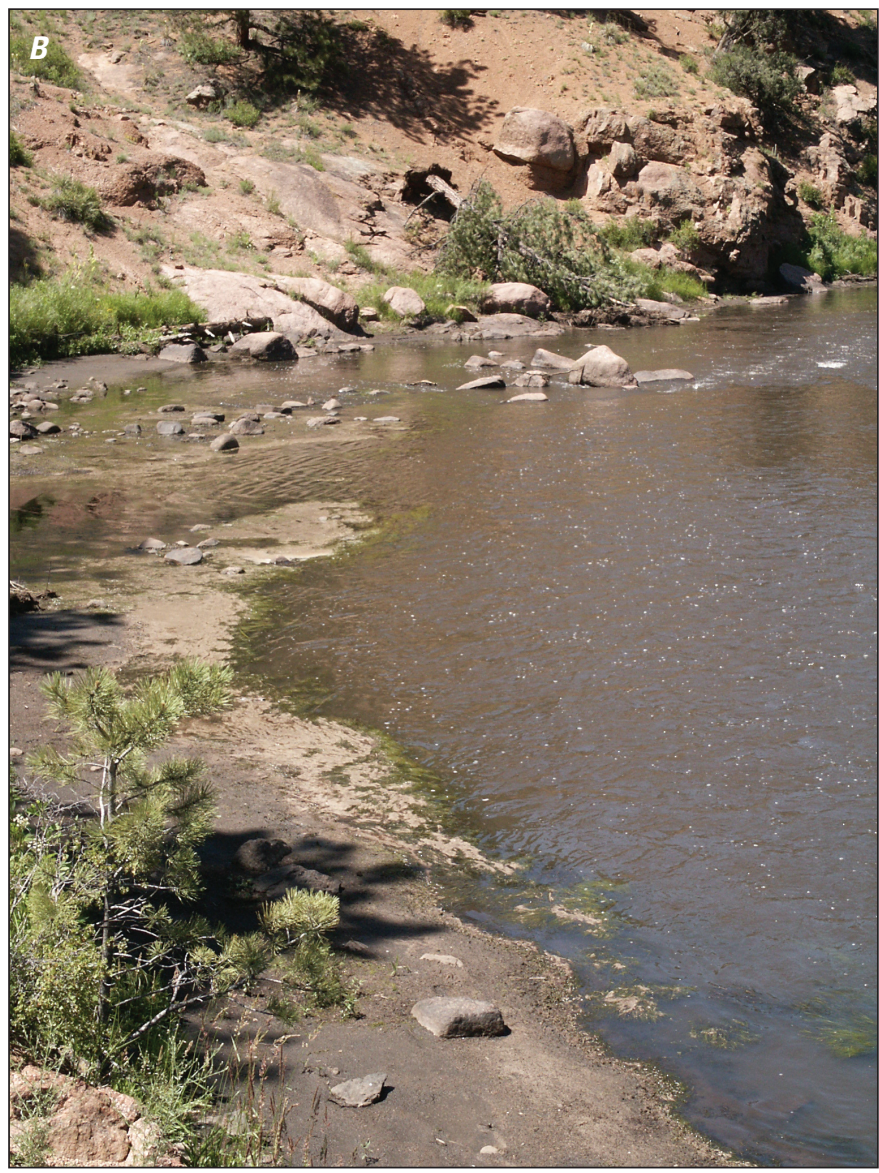

Simoneit and others, 2000). Classes of organic compounds identified include terpenes, alkanes, ketones, organic acids, polycyclic aromatic hydrocarbons, and some volatile organic compounds, which are typical postfire combustion products. Many other detected compounds were identified as GC-MS peaks but were not included in the laboratory database.

Quantitative analyses also were made for a limited number of common polycyclic aromatic hydrocarbon (PAH) organic compounds (six samples from Fourmile and one sample from Pine). Few concentrations were larger than the MRL (appendix 8). The only samples with concentrations higher than the MRL were collected from Fourmile (anthracene, benzo[a]-pyrene, chrysene, and naphthalene) (appendix 8). Even though GC-MS scans indicate that many compounds are present, the concentrations of these compounds may be limited, and dilution likely prevents any substantial concentrations in larger streams. However, the cumulative or synergistic toxicity of the many potentially toxic compounds in these complex mixtures could still pose a threat to aquatic health despite the small concentration of any single compound (Parvez and others, 2009; Barron and others, 2004). The limited number of compounds quantitatively analyzed also may leave out many potent toxins present in these samples.

\section{Trace Elements}

Trace elements are defined as inorganic chemical elements (excluding major ions and nutrients) that are usually found in natural water in low concentrations, generally less 
than $1 \mathrm{mg} / \mathrm{L}$ (Hem, 1985). In this study, concentrations of iron and manganese sometimes exceeded $1 \mathrm{mg} / \mathrm{L}$, but for the purposes of this study, iron and manganese are considered trace elements. Trace elements in the Hayman and Hinman fire areas are largely unaffected by acid-sulfate weathering processes because of a lack of sulfide mineral deposits or mining activity in the study areas.

The $\mathrm{pH}$ of water is a primary control on the solubility of trace elements (Smith, 2007). Generally, the most soluble chemical forms of many trace elements occur in acidic waters, whereas the insoluble forms of many trace elements occur in neutral or basic waters. Total recoverable trace-element concentrations usually increase as the suspended-sediment concentration increases because the total recoverable analyses include the portion of the sample that is soluble in a mild-acid extraction. Thus, much of the trace element adsorbed to sediment will be a part of the concentration that would be removed by filtration in a dissolved analysis.

Summary statistics for trace elements are listed in appendix 2. Median instantaneous concentrations and loads were substantially larger in Fourmile than in Pine for dissolved aluminum, arsenic, iron, and lead; total recoverable concentrations and loads were substantially larger in Fourmile than in Pine, only for copper, iron, lead, manganese, and zinc (appendix 2). For example, the median total recoverable manganese concentrations and loads in Fourmile were $505 \mathrm{mg} / \mathrm{L}$ and $3.28 \mathrm{lbs} / \mathrm{d}$, whereas Pine medians were $7.9 \mathrm{mg} / \mathrm{L}$ and $0.021 \mathrm{lb} / \mathrm{d}$, respectively. Stream samples collected from Fourmile during rainstorms contained some of the largest trace-element concentrations collected during the study, but as explained previously, no comparable storm runoff events were observed or sampled at Pine.

Comparison of paired instantaneous trace-element concentrations and loads at Fourmile and Pine using the Wilcoxon signed-rank test indicated larger concentrations at Fourmile ( $\mathrm{p}$-value $<0.10$ ) for dissolved and total recoverable concentrations of aluminum, arsenic, iron, and manganese but larger total recoverable concentrations at Fourmile only for cadmium, copper, lead, mercury, and zinc (table 3). Larger loads were computed for Fourmile than for Pine for dissolved and total recoverable iron and manganese, and for total recoverable aluminum, arsenic, cadmium, copper, lead, mercury, and zinc (table 3).

Total recoverable trace-element concentrations in samples of runoff from both Fourmile and Pine were substantially larger (by several times) than dissolved trace-element concentrations, indicating that most trace elements were particulate. In both streams of the Hayman fire area, large concentrations of total recoverable iron, manganese, and aluminum were measured (appendix 2).

Mercury was almost exclusively analyzed as total recoverable in this study, which includes both the dissolved and particulate fractions. The total recoverable mercury concentrations at Fourmile ranged from less than 0.010 to 0.381 $\mu \mathrm{g} / \mathrm{L}$ (appendix 2). The maximum concentration normalized to the suspended-sediment concentration in the sample was 0.0069 micrograms per gram $(\mu \mathrm{g} / \mathrm{g})$. However, when bulk bed sediment was collected from the YMCA Camp Shady Brook pond (Kiwanis Lake) located just downstream from the Fourmile sampling site, the concentration of mercury in sediments was relatively more enriched at $0.08 \mu \mathrm{g} / \mathrm{g}$ (appendix 9), which is similar to the $0.07 \mu \mathrm{g} / \mathrm{g}$ in forest-floor surface soil in the region (Perry and others, 2006). In general, total recoverable mercury concentrations were highest in samples with high suspended-sediment concentrations. The total recoverable mercury concentrations found in the routine samples indicate that substantial amounts of mercury, related to suspendedsediment transport, were mobilized from the burned Hayman watersheds. The high volatility of mercury may contribute to high losses of mercury from surface materials that are heated during a fire. Some of the vaporized mercury may subsequently be redeposited in the fire area or be lost to fugitive smoke that is transported away from the fire area. However, it is likely that mercury in forest-floor soils that are eroded after a fire results from long periods of accumulated atmospheric deposition. Forest-floor soil contains most of the mercury pool in an ecosystem (Engle and others, 2006) and is the major source available for transport when erosion occurs. Mercury contained in shallow soil, litter, and above-ground biomass is volatilized during combustion (Biswas and others, 2008; Engle and others, 2006).

Samples from selected sites in the Hayman fire area were collected during low streamflow on October 27, 2004, and analyzed for dissolved and total recoverable mercury by using low-level techniques at a USGS Laboratory in Boulder, Colorado (table 6). These analyses showed no abnormally high dissolved concentrations of mercury (maximum dissolved concentration was $0.0009 \mu \mathrm{g} / \mathrm{L}$ at Pine). The data indicate that only small concentrations of dissolved mercury were transported during the low-flow sampling. Only two high-streamflow samples were analyzed for dissolved mercury (standard laboratory reporting levels) at Fourmile, and dissolved mercury in both samples was $<0.018 \mu \mathrm{g} / \mathrm{L}$ (appendix 1). More samples would be needed to determine if dissolved mercury transport is minimal during high-flow and all other seasonal periods. Maximum total recoverable mercury (low-level techniques) for the set of low-streamflow samples collected October 27, 2004, was $0.0360 \mu \mathrm{g} / \mathrm{L}$ at West Creek (table 6) (fig. 1), which is a relatively high concentration that was related to fine suspended sediment in the water column from a storm runoff event in upper West and Trail Creeks.

Most of the CDPHE stream standards for trace elements likely would not be exceeded because the waterquality standards apply primarily to dissolved-phase (filtered at 0.45 micrometers $[\mu \mathrm{m}]$ ) constituents, and the predominant phase associated with Hayman postfire runoff is particulate, similar to findings in Gallaher and others (2002) at the Cerro Grande Fire in Los Alamos, New Mexico. Dissolved mercury is not adequately documented in this report, but the CDPHE 
stream standard is for total mercury. Specific water-quality standards and exceedances are discussed later in this report in "Water-Quality Standards and Aquatic Life." Concentrations of dissolved iron and manganese were high the first year (2003) after the Hayman fire but decreased in subsequent years (2004-2007) (appendix 1). Other trace element concentrations at Fourmile also have decreased over the same period.

\section{Hinman Fire Study Area}

Summary statistics and selected time-series plots of instantaneous concentrations and loads for water-quality constituents in the Hinman fire study area are listed in appendix 2 and shown in figures 29-32.

\section{Field and Laboratory Measurements and Major Ions}

Median values of specific conductance and concentrations of the major ions calcium, magnesium, potassium, chloride, and sulfate, indicated that postfire samples at Lost Dog contained larger concentrations than prefire samples (fig. 24; appendix 2). Concentrations of sodium, acid-neutralizing capacity, and silica were larger in prefire samples at Lost Dog. Stream major-ion chemistry was predominantly calciumbicarbonate type (as indicated by concentrations of calcium and acid-neutralizing capacity and by $\mathrm{pH}$ ). Instantaneous loads of all major ions and streamflow-weighted measurements indicated that postfire samples at Lost Dog had larger loads than prefire samples (fig. 25) (appendix 2). For example, the median prefire calcium concentrations and loads at Lost Dog were $3.91 \mathrm{mg} / \mathrm{L}$ (180 lbs/d), whereas postfire medians were $5.61 \mathrm{mg} / \mathrm{L}(835 \mathrm{lbs} / \mathrm{d})$, respectively (appendix 2 ).

Selected plots of water-quality constituent relations provided insight into hydrologic pathways and timing of postfire effects on streams. A plot of the relation between calcium and streamflow at Lost Dog (fig. 33A) shows that calcium concentrations (similar to the other major ions) for the 2003 risinglimb hydrograph (when leaching of burned surface materials was greatest) were much larger than the prefire-1999-2000, the postfire 2003 falling limb, and the postfire 2006 concentrations. The increase in calcium concentrations is consistent with increased calcium oxides and carbonates available for dissolution in ash and heat-altered soil minerals immediately following a fire (Bitner and others, 2001). Calcium and other major ions mobilized by fire are available in surficial material to be dissolved and flushed into streams or enter the flushing zone in shallow soils. In contrast, silica concentrations showed little evidence of increased concentrations or alterations of prefire dilution patterns during high streamflows associated with rising limb of 2003 streamflow hydrograph following the fire (fig. 33B). Instead silica had a similar pattern to samples from other periods, including the prefire data. Silica relations with streamflow may indicate that the surficial effects of fire did not increase sources or create geochemical conditions conducive to mobilization of soluble silica available to meltwater at this site. The unaltered silica relation with streamflow also may indicate that soil infiltration was a minor pathway for postfire meltwater, possibly a result of a shallow water-repellant soil layer.

Comparisons of field measurements and major-ion concentrations and loads for prefire and postfire samples at Lost Dog using the Mann-Whitney rank-sum test also indicated larger postfire values and concentrations in Lost Dog (p-value $<0.10$ ) for specific conductance, calcium, potassium, and sulfate (table 7). The median concentration of silica, however, was larger in prefire samples compared to postfire samples. Larger postfire loads compared to prefire loads were found for all major ions and streamflow-weighted specific conductance except silica (table 7).

Comparisons of instantaneous field-measurement and major-ion concentrations and loads for prefire (1999-2000) and postfire (2003) samples in North Fork Elk were made using the Mann-Whitney rank-sum test. Results indicated larger postfire values and concentrations at North Fork Elk (p-value $<0.10$ ) for potassium and sulfate, and larger loads for flow-weighted specific conductance, calcium, magnesium, potassium, sulfate and chloride (table 8). Similar to the results of the Hayman fire paired-watershed comparison, major ions are released by burned watersheds.

Table 6. Results of low-level mercury analysis at selected Hayman sampling sites on October 27, 2004.

$[\mu \mathrm{g} / \mathrm{L}$, micrograms per liter; -, no data; detection limit $0.0004 \mu \mathrm{g} / \mathrm{L}]$

\begin{tabular}{lcc}
\hline \multicolumn{1}{c}{ Site name } & $\begin{array}{c}\text { Dissolved mercury } \\
\boldsymbol{\mu g} / \mathbf{L}\end{array}$ & $\begin{array}{c}\text { Total recoverable } \\
\text { mercury } \\
\boldsymbol{\mu g} / \mathbf{L}\end{array}$ \\
\hline South Platte River above Brush Creek near Trumbull & 0.0005 & 0.0093 \\
South Platte River above Brush Creek near Trumbull & - & 0.0074 \\
West Creek at West Creek & 0.0005 & 0.0360 \\
Fourmile Creek above YMCA-Camp Pond near Deckers & 0.0006 & 0.0108 \\
Fourmile Creek above YMCA-Camp Pond near Deckers & 0.0006 & - \\
Pine Creek above Sprucewood & 0.0009 & 0.0045 \\
Filter Blank & - & 0.0025 \\
Field Blank & 0.0004 & - \\
\hline
\end{tabular}



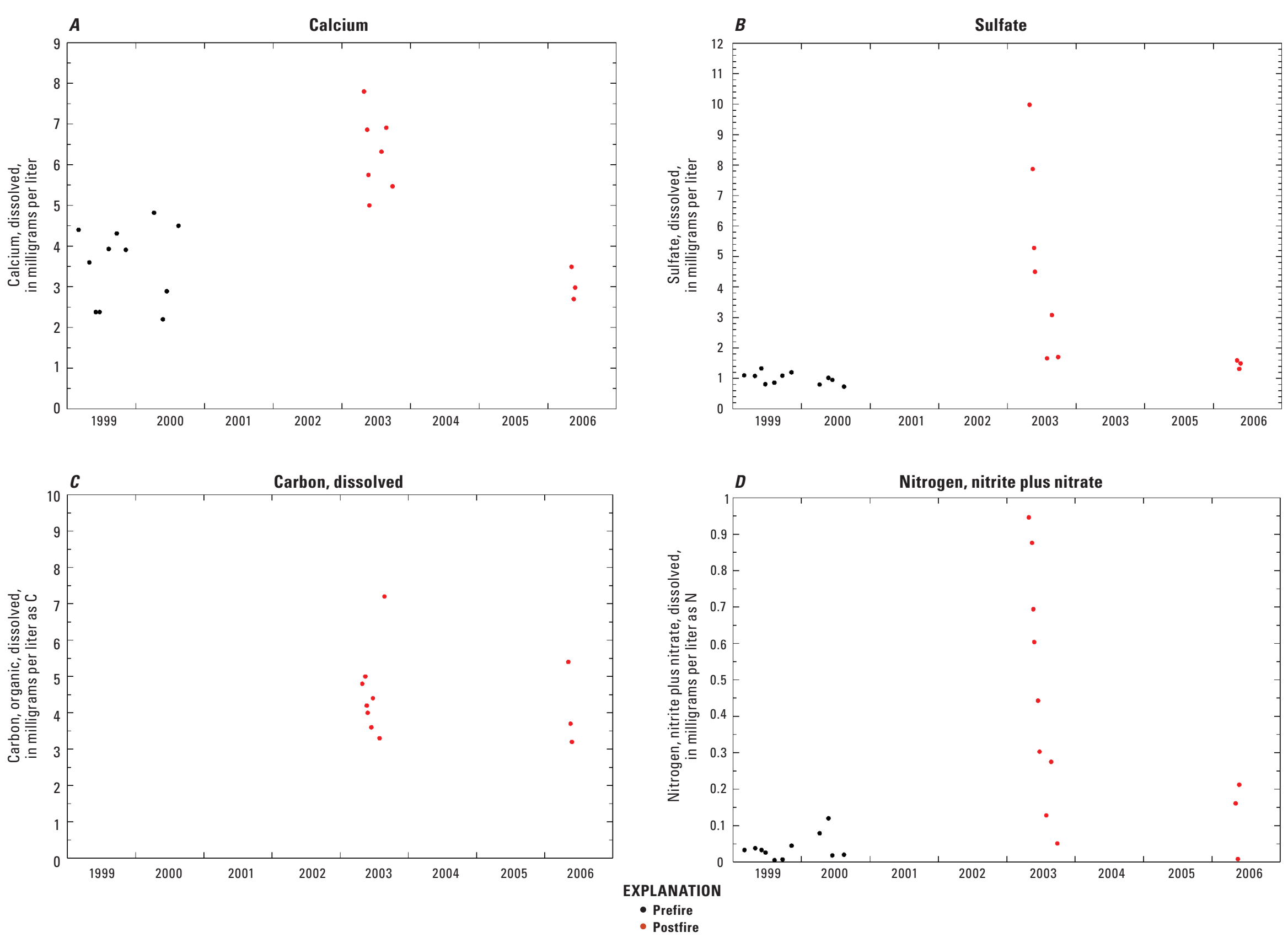

Figure 29. Graphs showing concentrations of selected water-quality constituents at Lost Dog Creek, 1999-2006. 

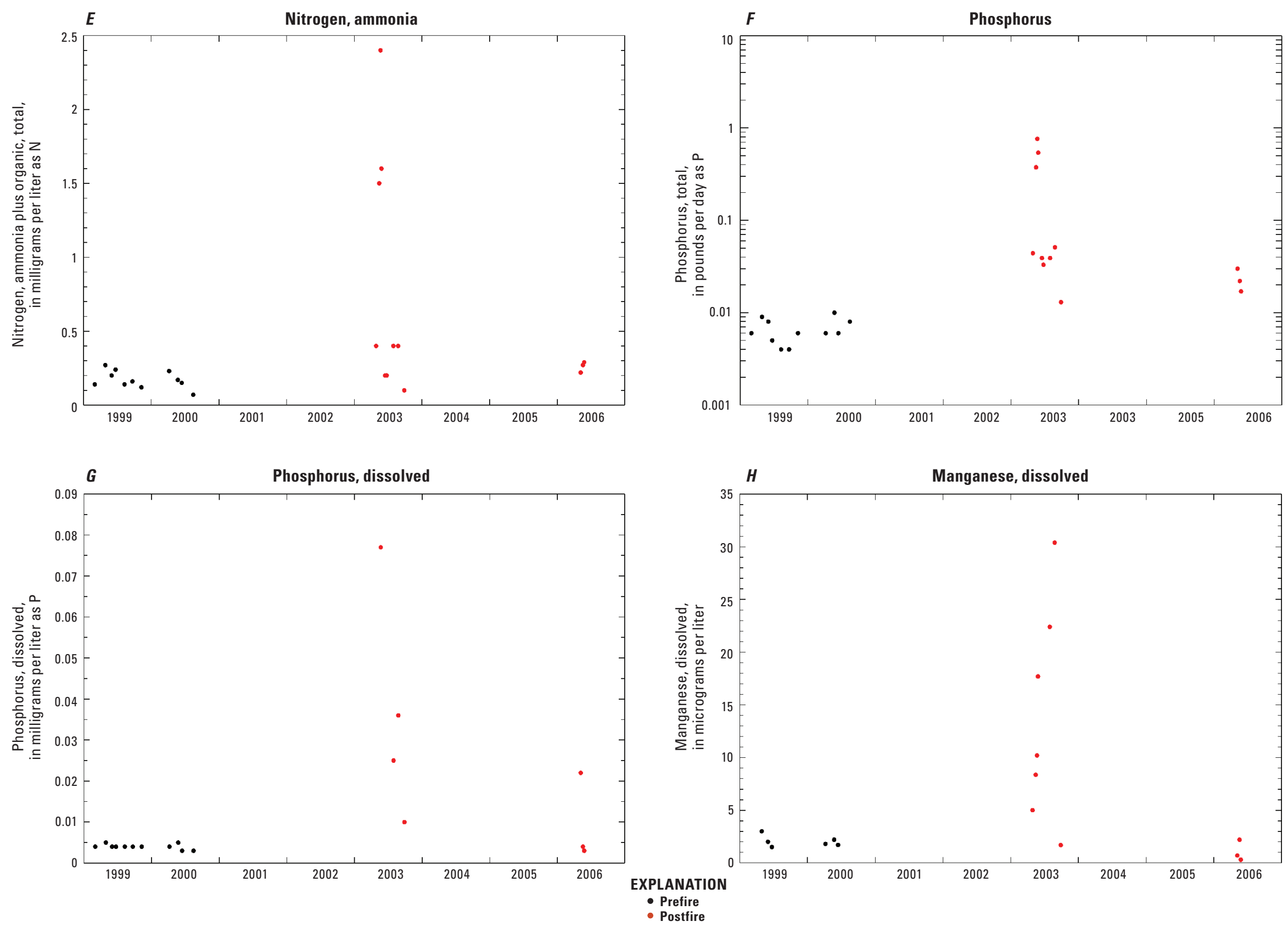

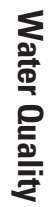

Figure 29. Graphs showing concentrations of selected water-quality constituents at Lost Dog Creek, 1999-2006.—Continued 

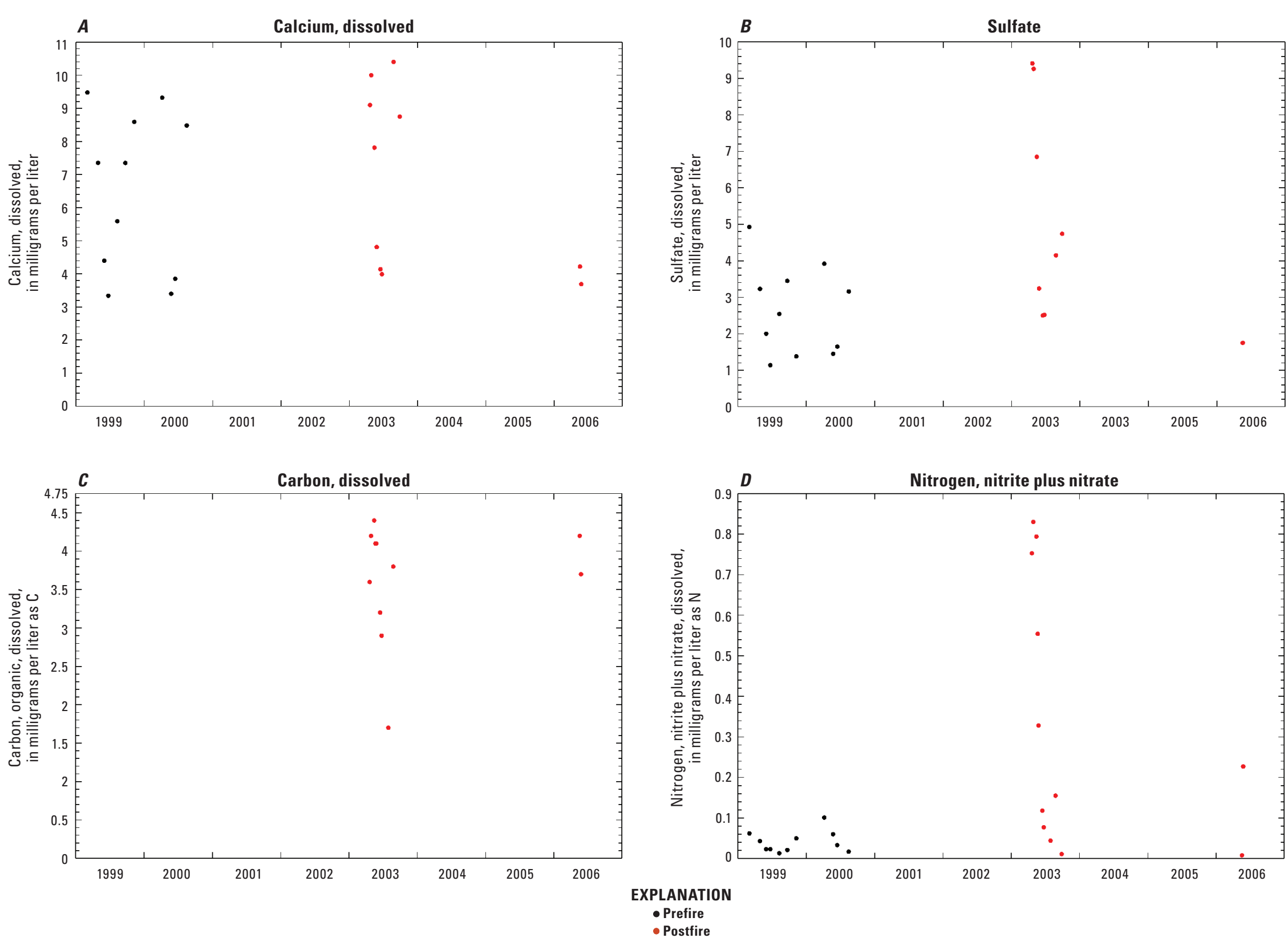

Figure 30. Graphs showing concentrations of selected water-quality constituents at North Fork Elk River, 1999-2006. 

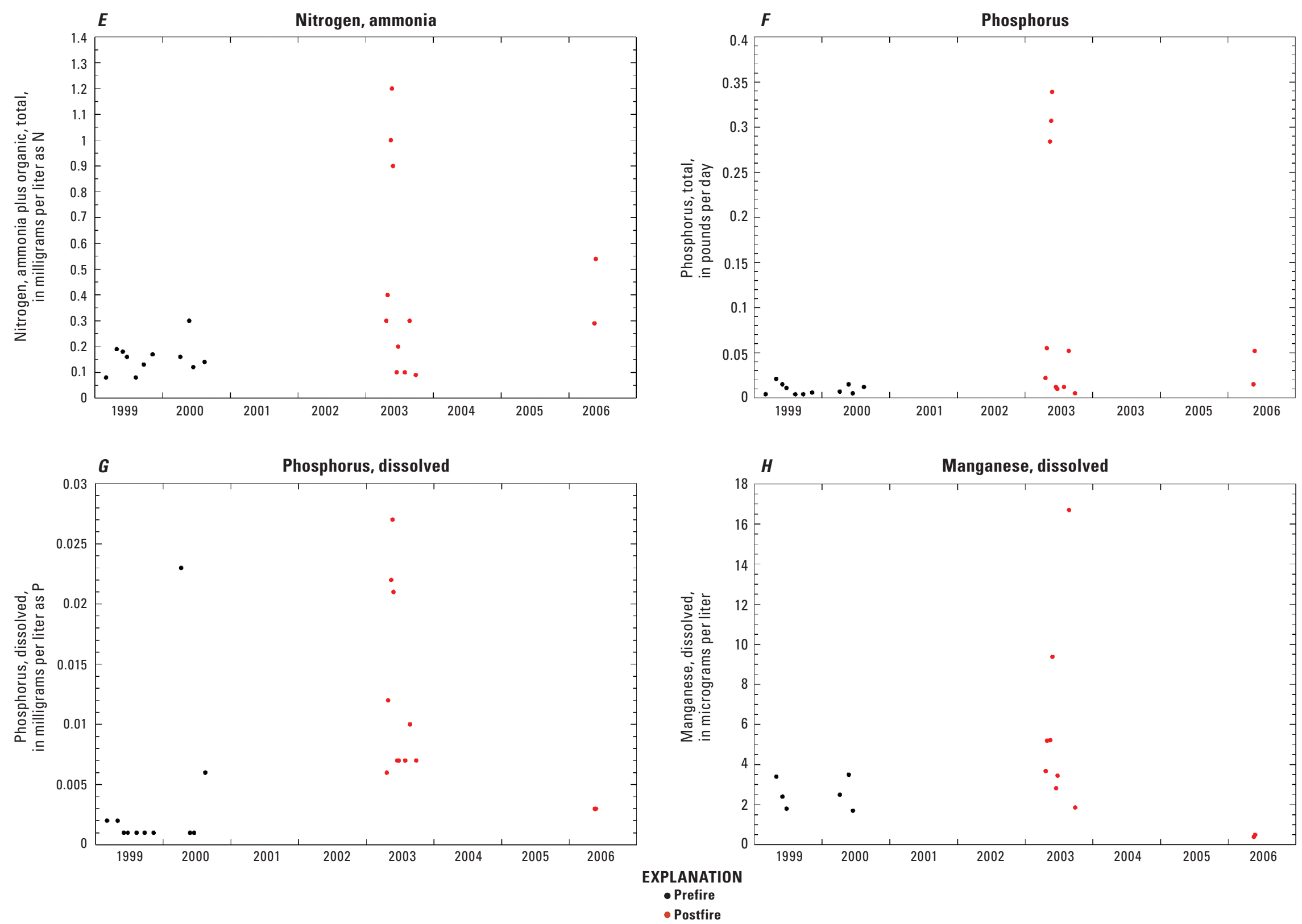

Figure 30. Graphs showing concentrations of selected water-quality constituents at North Fork Elk River, 1999-2006. - Continued 

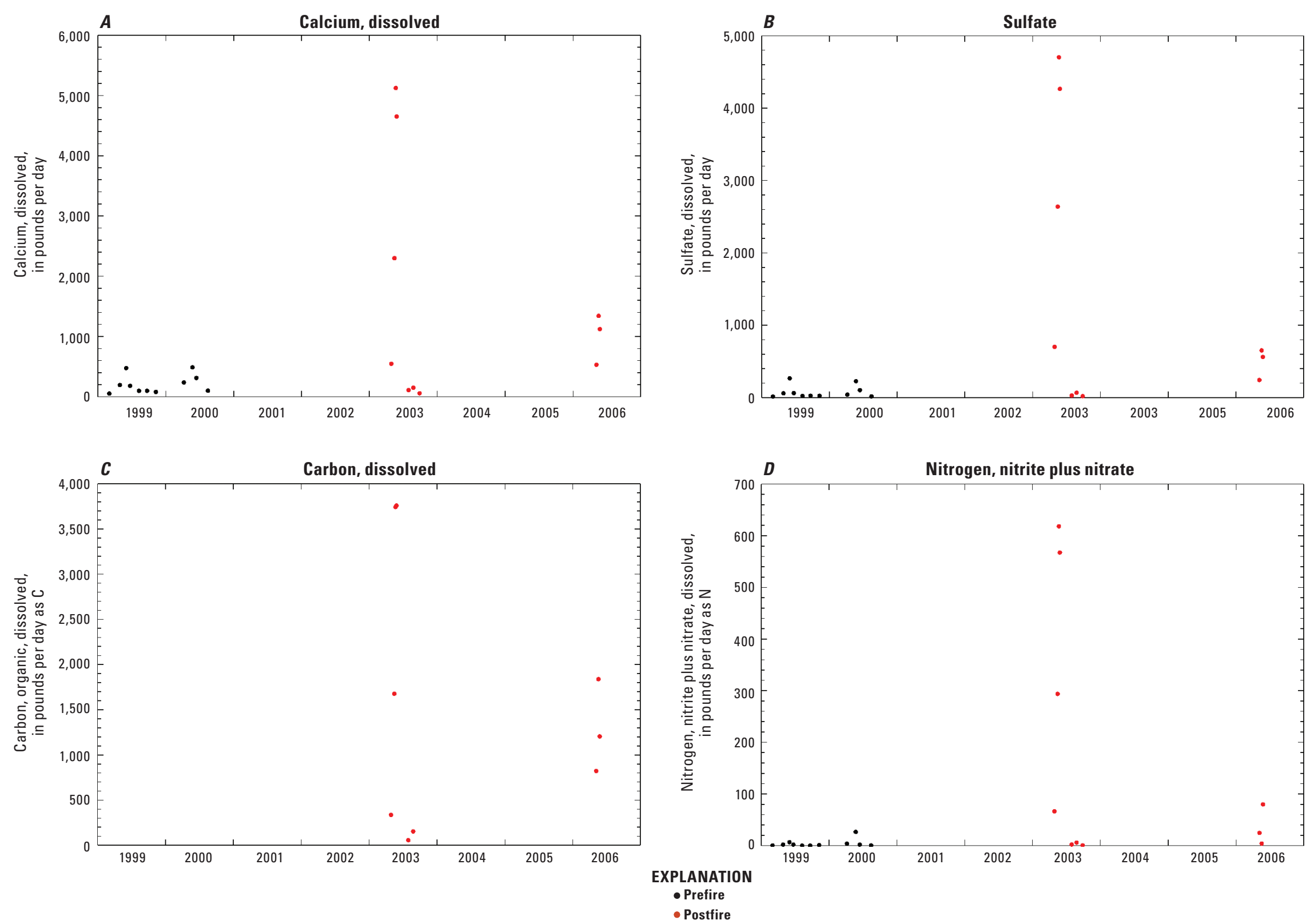

Figure 31. Graphs showing loads of selected water-quality constituents at Lost Dog Creek, 1999-2006. 

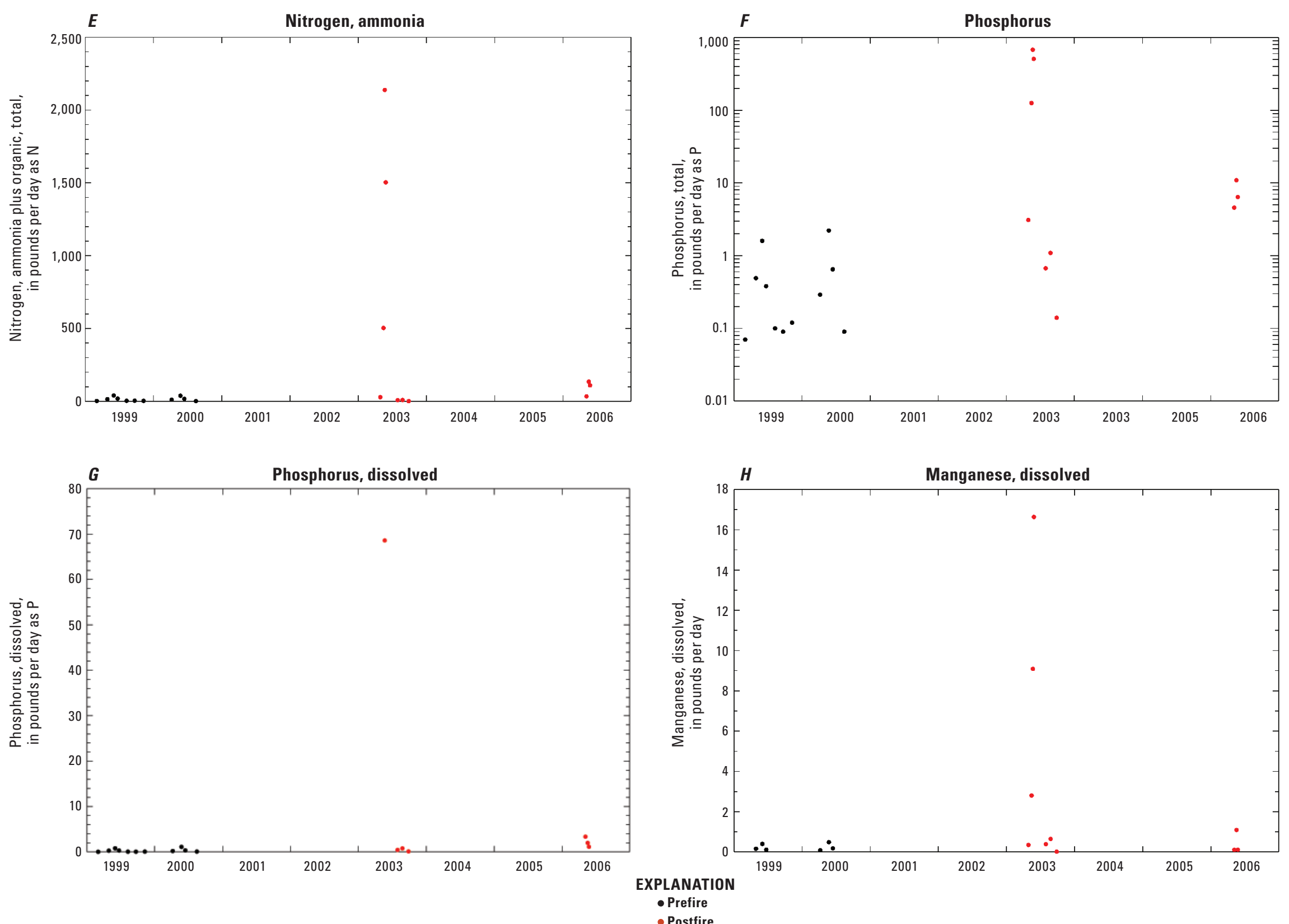

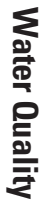

Figure 31. Graphs showing loads of selected water-quality constituents at Lost Dog Creek, 1999-2006. - Continued 

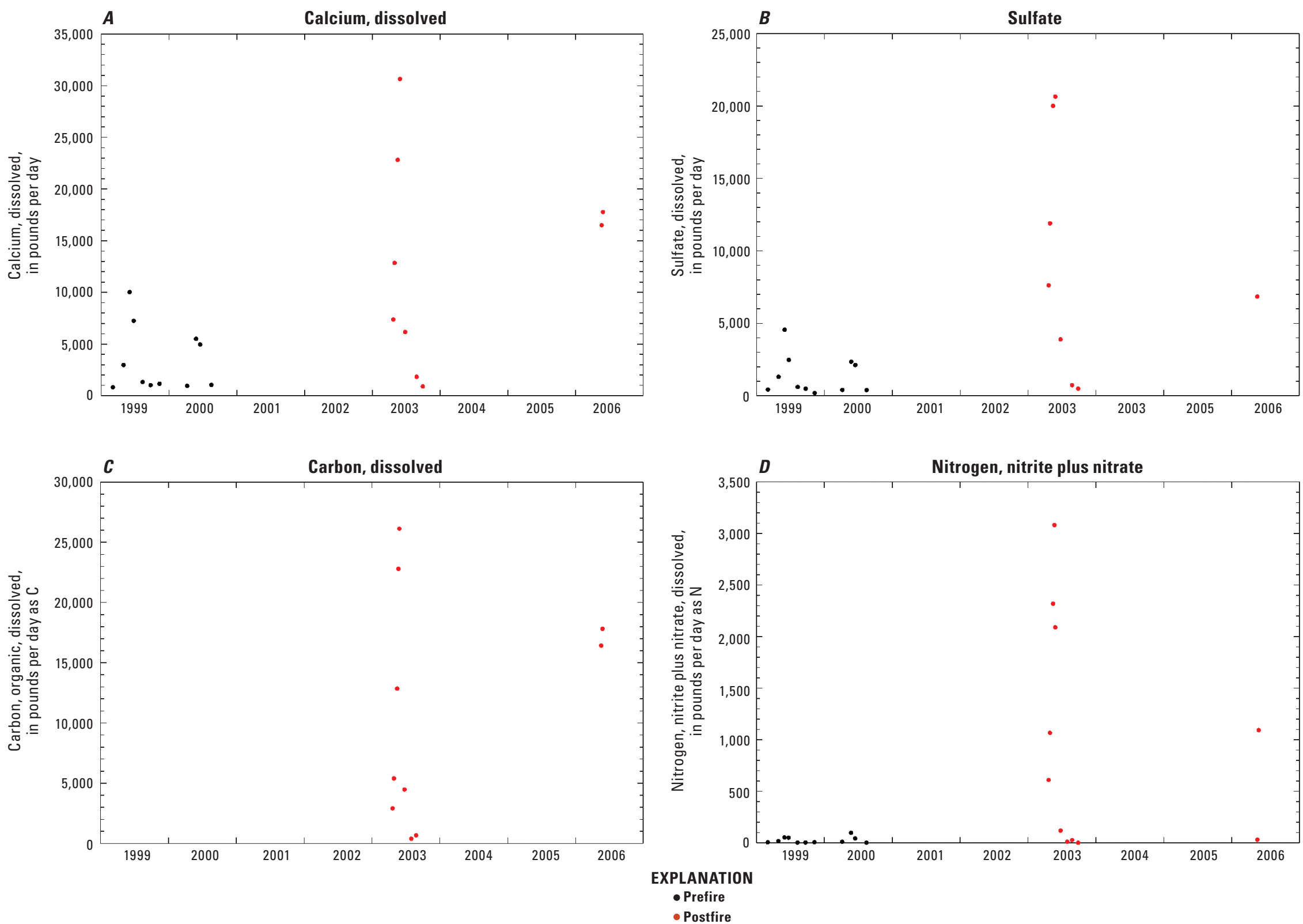

Figure 32. Graphs showing loads of selected water-quality constituents at North Fork Elk River, 1999-2006. 

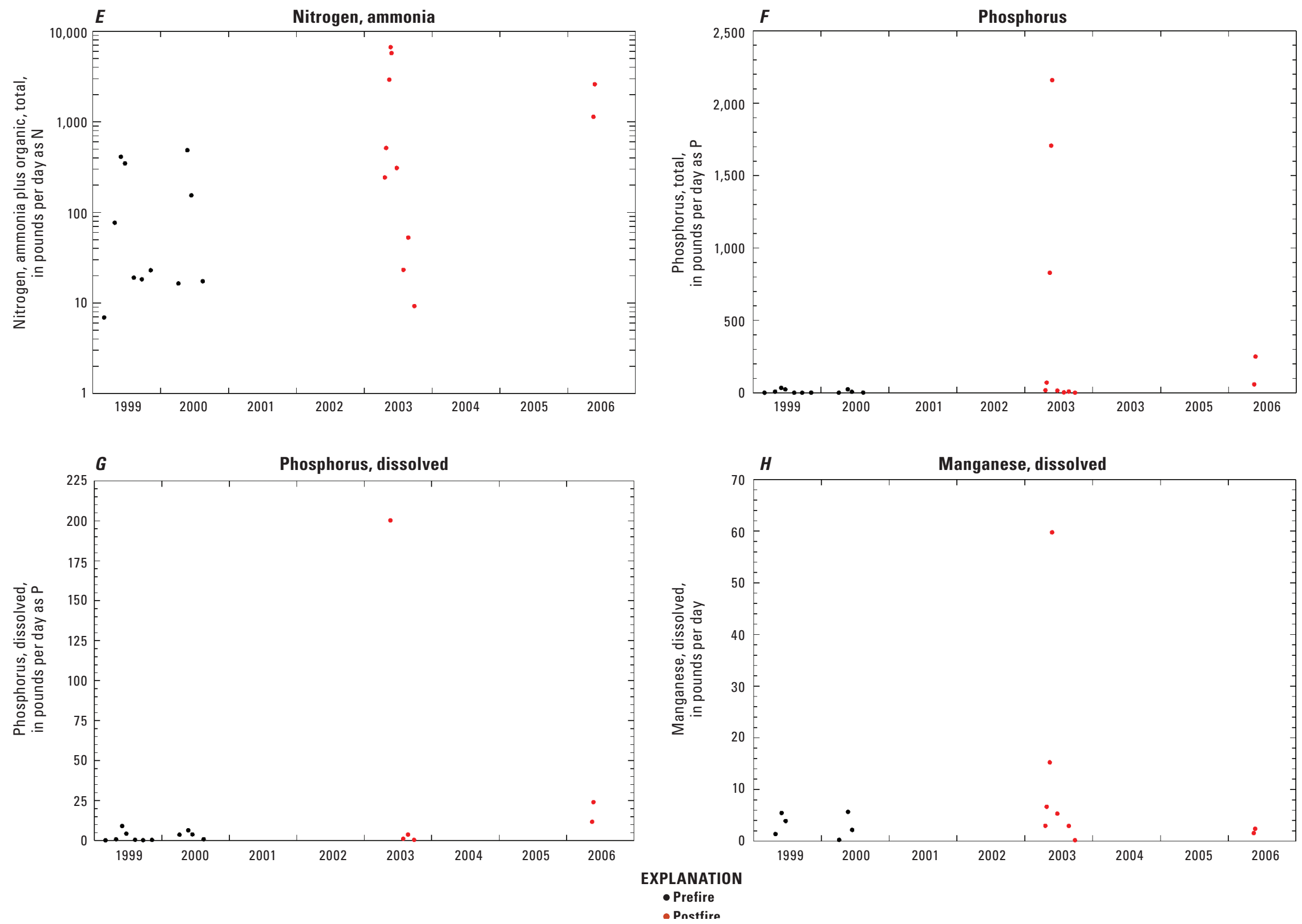

Figure 32. Graphs showing loads of selected water-quality constituents at North Fork Elk River, 1999-2006. - Continued 

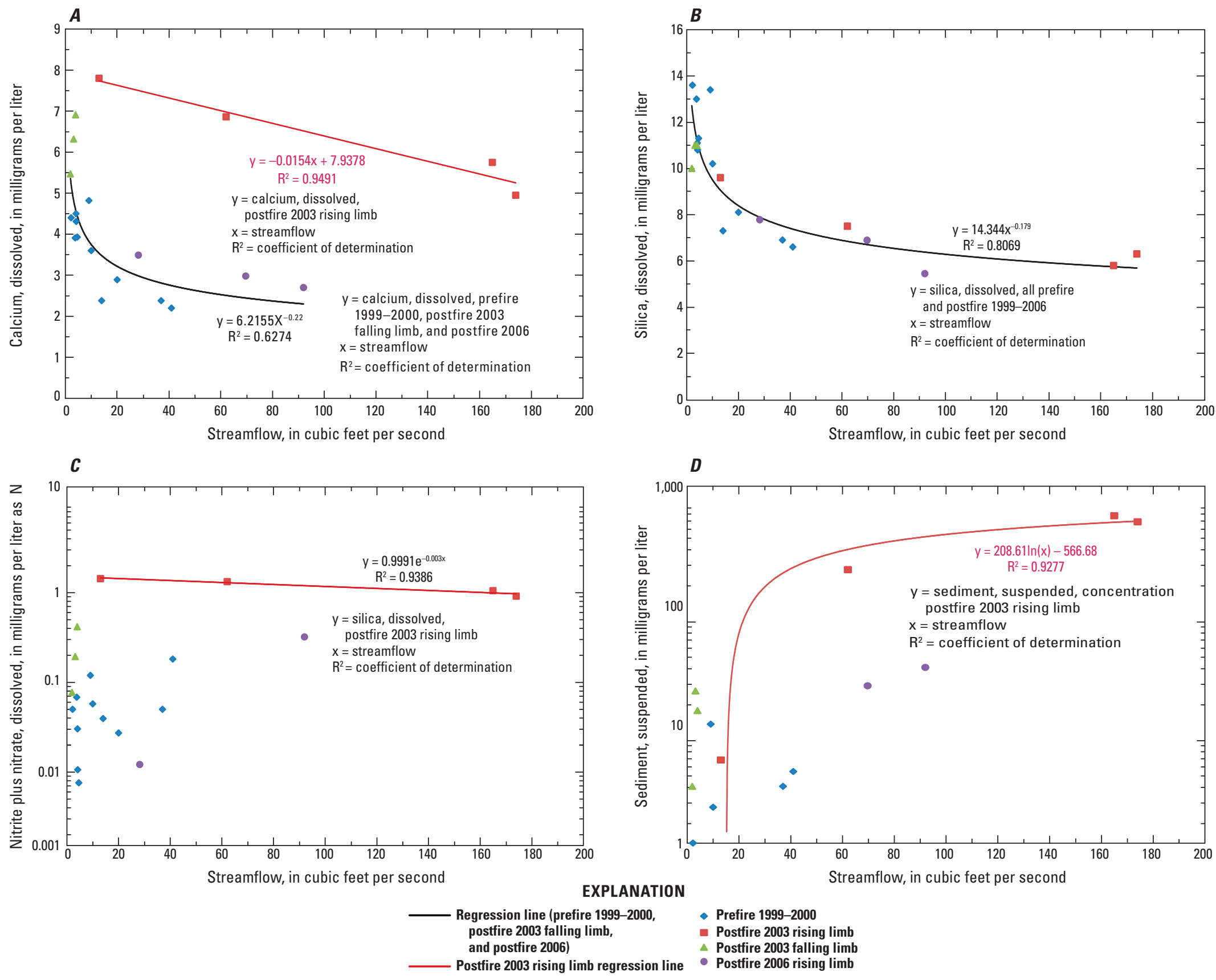

Figure 33. Graphs showing water-quality constituent concentration relations with streamflow for $A$, calcium; $B$, silica; $C$, nitrite plus nitrate; and $D$, suspended sediment at Lost Dog Creek. 
Table 7. Mann-Whitney test of differences between prefire (1999-2000) and postfire (2003) water-quality measurements, concentrations, and loads normalized to drainage area at Lost Dog Creek.

[Specific conductance, turbidity, and ultraviolet absorption at $254 \mathrm{~nm}$ are multiplied by streamflow but are not mass loads; -, no data; n, number of samples; shaded values indicate a larger median that is considered statistically significant for this report with a p-value less than or equal to $0.10 ; \mathrm{mg} / \mathrm{L}, \mathrm{milligrams} \mathrm{per} \mathrm{liter;} \mathrm{mi}^{2}$, square mile; $\mu \mathrm{g} / \mathrm{L}$, micrograms per liter; ${ }^{\circ} \mathrm{C}$, degrees Celsius; $\mathrm{ft}^{3} / \mathrm{s}$, cubic feet per second; $\mu \mathrm{S} / \mathrm{cm}$ at $25^{\circ} \mathrm{C}$, microsiemens per centimeter at $25^{\circ} \mathrm{C} ; \mu \mathrm{S}-\mathrm{ft}^{3} / \mathrm{cm}^{-\mathrm{s}} / \mathrm{mi}^{2}$, microsiemens cubic feet per centimeter seconds per square mile; $\mathrm{cm}^{-1}$, per centimeter; NTU-ft $\mathrm{fl}^{3} / \mathrm{s}-\mathrm{mi}^{2}$, nephelometric turbidity units cubic feet per second square mile; $\mathrm{lb} / \mathrm{d} / \mathrm{mi}^{2}$, pounds per day per square mile; $\mathrm{CaCO}_{3}$, calcium carbonate; $\mathrm{N}$, nitrogen; $\mathrm{P}$, phosphorus; $\mathrm{C}$, carbon; nm, nanometers; $\mathrm{cm}$, centimeter; $\mathrm{lb} / \mathrm{d}$, pounds per day; $\mathrm{t} / \mathrm{d}$, tons per day; $\mathrm{t} / \mathrm{d} / \mathrm{mi}^{2}$, tons per day per square mile]

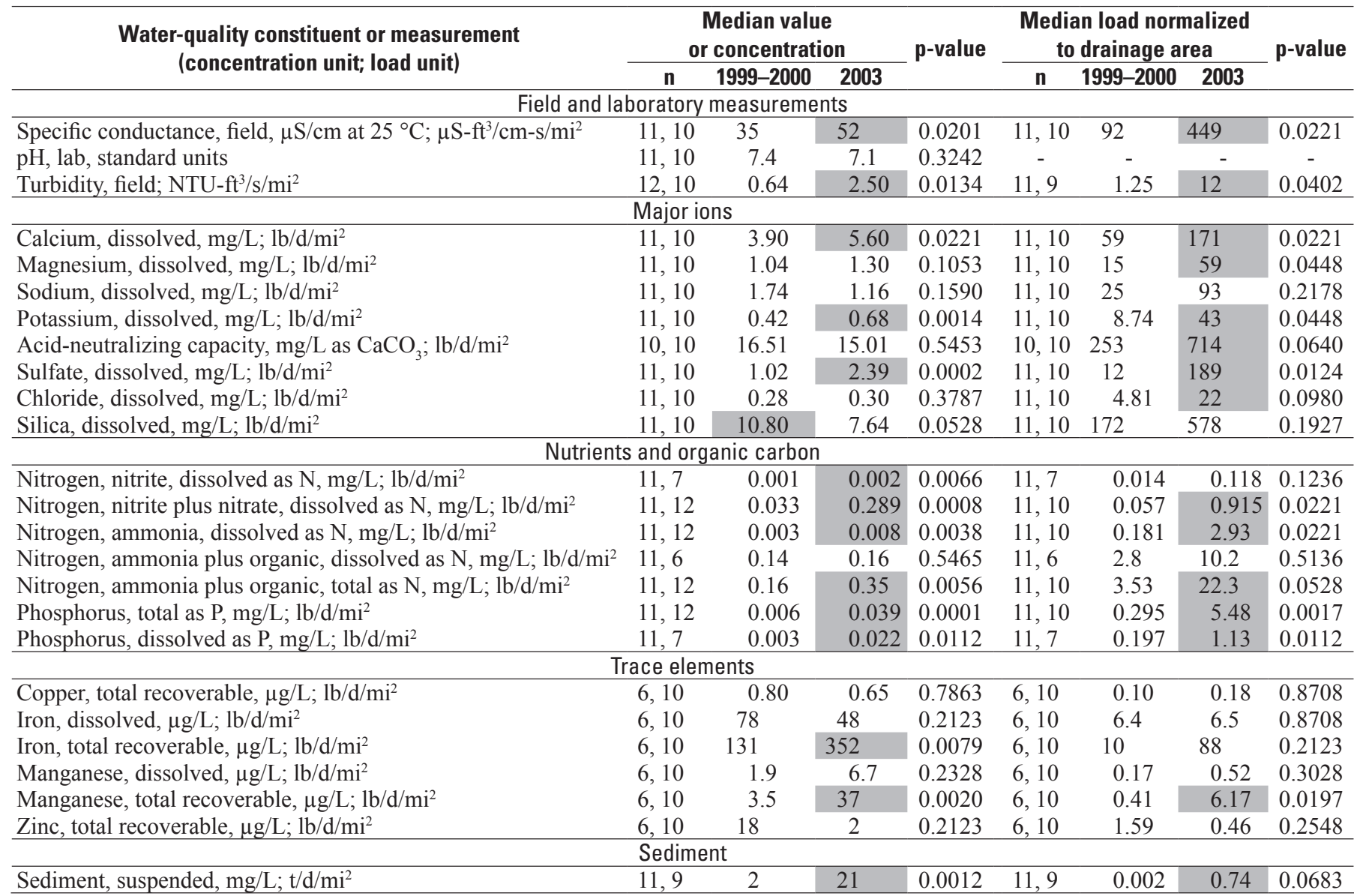

\section{Nutrients and Organic Carbon}

Selected nutrient concentrations in Lost Dog including total ammonia plus organic nitrogen, and dissolved ammonia, nitrite plus nitrate, and total phosphorus (orthophosphorus was not analyzed in prefire samples) indicated larger postfire than prefire concentrations and loads (figs. 24, 25 and 29-32) (appendix 2). Similarly, selected nutrient concentrations and loads in North Fork Elk including total ammonia plus organic nitrogen, ammonia, nitrite plus nitrate, total phosphorus, and orthophosphorus were larger during postfire than prefire conditions. For example, prefire median concentrations and loads of dissolved nitrite plus nitrate at Lost Dog were $0.033 \mathrm{mg} / \mathrm{L}$ and $1.94 \mathrm{lbs} / \mathrm{d}$, whereas postfire medians were $0.289 \mathrm{mg} / \mathrm{L}$ and $45.5 \mathrm{lbs} / \mathrm{d}$. Median prefire concentrations and loads of total phosphorus at North Fork Elk were $0.007 \mathrm{mg} / \mathrm{L}$ and $1.49 \mathrm{lbs} / \mathrm{d}$, whereas postfire medians were $0.037 \mathrm{mg} / \mathrm{L}$ and $58.6 \mathrm{lbs} / \mathrm{d}$.
Comparison of instantaneous nutrient concentrations and loads for prefire and postfire using the Mann-Whitney ranksum test indicated larger postfire concentrations in Lost Dog ( $p$-value $<0.10$ ) for total ammonia plus organic nitrogen, and dissolved nitrite, nitrite plus nitrate, and ammonia, and total and dissolved phosphorus (table 7). The postfire concentrations at high streamflow were sometimes several times higher than the prefire concentrations (appendix 1). Loads were significantly larger $(\mathrm{p}<0.10)$ for the same nutrients except for dissolved nitrite and dissolved ammonia plus organic nitrogen (table 7). Comparison of instantaneous nutrient concentrations and loads for prefire and postfire using the Mann-Whitney rank-sum test indicated larger postfire nutrient concentrations in North Fork Elk (p-value $<0.10$ ) for dissolved nitrite, nitrite plus nitrate, ammonia, total ammonia plus organic nitrogen, total and dissolved phosphorus, and orthophosphorus 
Table 8. Mann-Whitney test of differences between prefire (1999-2000) and postfire (2003) water-quality measurements, concentrations, and loads normalized to drainage area at North Fork Elk River.

[Specific conductance, turbidity, and ultraviolet absorption at $254 \mathrm{~nm}$ are multiplied by streamflow but are not mass loads; -, no data; n, number of samples; shaded values indicate a larger median that is considered statistically significant for this report with a p-value less than or equal to $0.10 ; \mathrm{mg} / \mathrm{L} ; \mathrm{mi}^{2}$, square mile; milligrams per liter; $\mu \mathrm{g} / \mathrm{L} ;$ micrograms per liter; ${ }^{\circ} \mathrm{C}$, degrees Celsius; $\mathrm{ft} / \mathrm{s}$, cubic feet per second; $\mu \mathrm{S} / \mathrm{cm}$ at $25^{\circ} \mathrm{C}$, microsiemens per centimeter at $25^{\circ} \mathrm{C} ; \mu \mathrm{S}-\mathrm{ft} / \mathrm{cm}-\mathrm{s} / \mathrm{mi}^{2}$, microsiemens cubic feet per centimeter seconds per square mile; NTU-ft $\mathrm{ft}^{3} \mathrm{~s}-\mathrm{mi}^{2}$, nephelometric turbidity units cubic feet per second square mile; $1 \mathrm{~b} / \mathrm{d} / \mathrm{mi}^{2}$, pounds per day per square mile; $\mathrm{CaCO}_{3}$, calcium carbonate; $\mathrm{N}$, nitrogen; $\mathrm{P}$, phosphorus; $\mathrm{C}$, carbon; nm, nanometers; $\mathrm{cm}$, centimeter; $1 \mathrm{~b} / \mathrm{d}$, pounds per day; $\mathrm{t} / \mathrm{d}$, tons per day; $\mathrm{t} / \mathrm{d} / \mathrm{mi}^{2}$, tons per day per square mile]

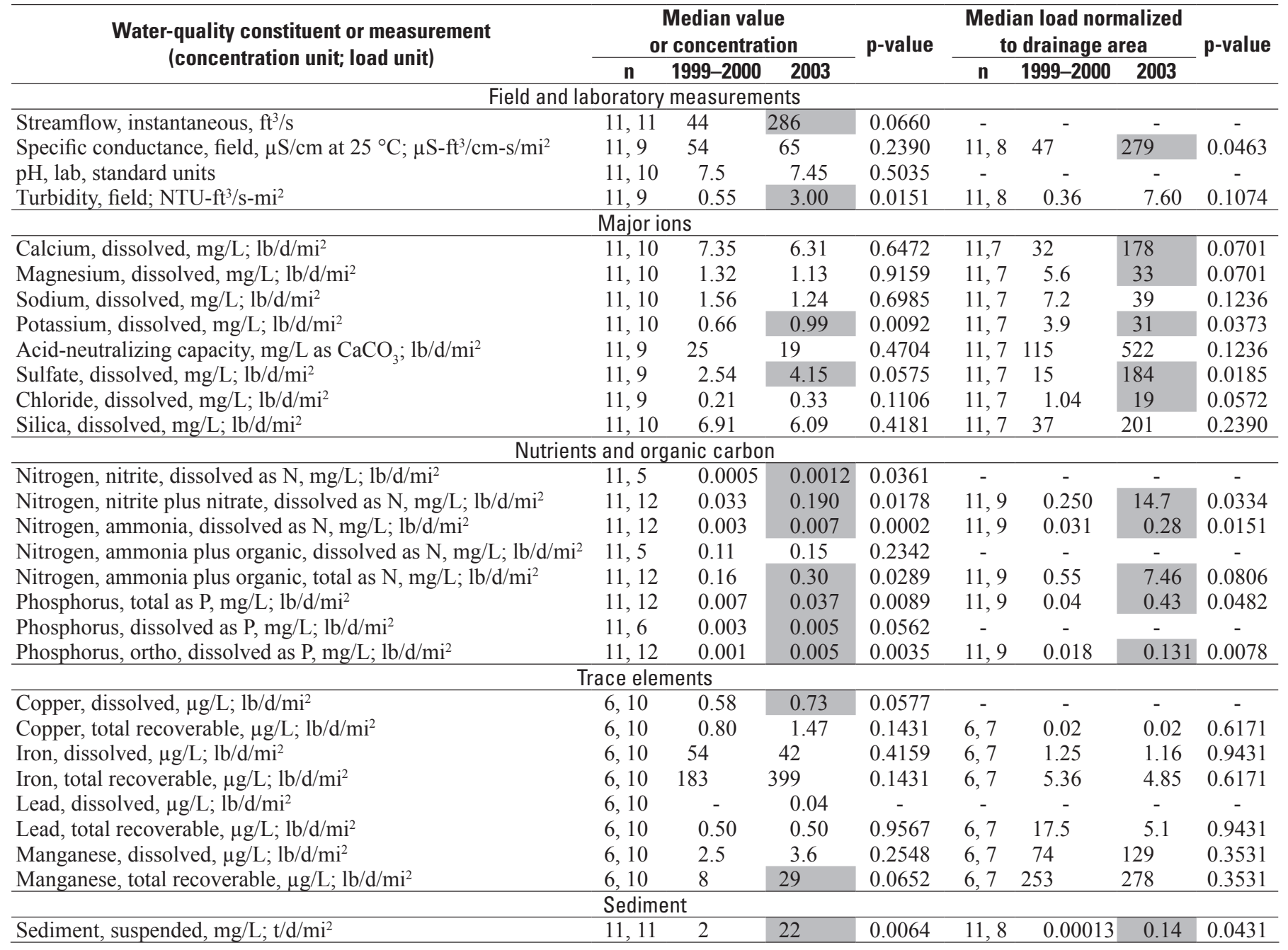

(table 8) and larger loads for nitrite plus nitrate, ammonia, total ammonia plus organic nitrogen, total phosphorus, and orthophosphorus.

A plot of the relation between nitrite plus nitrate and streamflow at Lost Dog (fig. 33C) shows that concentrations (similar to calcium, discussed previously) for the 2003 risinglimb hydrograph (when leaching of burned surface materials was greatest) were much larger than the prefire 1999-2000, 2003 falling limb, and 2006 postfire rising limb concentrations. The pattern may indicate that postfire effects on stream concentrations (and loads) are more important during periods of snowmelt, and that nutrients released from pyrolysis of vegetation and soil are released to surface or shallow flow paths, or nutrient retention is strong in deeper groundwater flow paths.
No prefire organic carbon analyses were done, but five postfire samples from the mouth of Mad Creek at the confluence with the main-stem Elk River were analyzed for DOC in 2003 (appendix 12). Most of Mad Creek watershed is very similar in character to the North Fork Elk River watershed. Mad Creek is unburned except for a very small area in the upper watershed that was burned in the Mad Creek fire in 2001 (only 957 acres were burned and the acreage was not entirely within the $36-\mathrm{mi}^{2}$ watershed of Mad Creek (U.S. Geological Survey, 2012). Median postfire DOC and TOC concentrations from Lost Dog and North Fork Elk were similar to concentrations (within about $1 \mathrm{mg} / \mathrm{L}$ ) observed in the unburned Mad Creek samples. Median DOC concentration in Mad Creek was $5.1 \mathrm{mg} / \mathrm{L}$ (appendix 1) compared to $4.2 \mathrm{mg} / \mathrm{L}$ for postfire Lost Dog and $3.8 \mathrm{mg} / \mathrm{L}$ for 
postfire North Fork Elk (appendix 2). Median TOC concentration in Mad Creek was $4.9 \mathrm{mg} / \mathrm{L}$ in 2003 compared to $5.2 \mathrm{mg} / \mathrm{L}$ for postfire Lost Dog and $5.6 \mathrm{mg} / \mathrm{L}$ for postfire North Fork Elk. However, concentrations of TOC detected in the burned streams (Lost Dog maximum $35 \mathrm{mg} / \mathrm{L}$ ) were higher than those in the unburned stream (Mad Creek maximum $9.5 \mathrm{mg} / \mathrm{L}$ ) during high streamflow. These results may indicate that under snowmelt conditions, postfire DOC concentrations may not increase or may be masked by dilution due to the increase in postfire streamflow.

\section{Trace Elements}

The distribution of the concentrations of total recoverable iron and dissolved and total recoverable manganese at Lost Dog and North Fork Elk indicated that postfire concentrations were larger than prefire concentrations (fig. 24). The distribution of the loads of dissolved and total recoverable manganese at Lost Dog and North Fork Elk indicated that postfire loads generally were larger than prefire loads (fig. 25). For example, median prefire dissolved manganese concentrations and loads were $1.9 \mathrm{mg} / \mathrm{L}$ and $0.17 \mathrm{lbs} / \mathrm{d}$ at Lost Dog, whereas postfire-median concentrations were $6.7 \mathrm{mg} / \mathrm{L}$ and $0.52 \mathrm{lbs} / \mathrm{d}$, respectively (appendix 2). Similarly, at North Fork Elk, median prefire dissolved manganese concentrations and loads were $2.4 \mathrm{mg} / \mathrm{L}$ and 3,050 lbs/d, whereas the postfire median concentration was $3.6 \mathrm{mg} / \mathrm{L}$ and the median load was $2,980 \mathrm{lbs} / \mathrm{d}$, respectively.

Comparison of instantaneous trace-element prefire and postfire concentrations and loads for Lost Dog using the Mann-Whitney rank-sum test indicated larger and statistically significant postfire concentrations ( $p$-value $<0.10$ ) for total recoverable iron and total recoverable manganese (table 7) and larger loads for total recoverable manganese. Comparison of prefire and postfire instantaneous trace-element concentrations and loads for North Fork Elk using the Mann-Whitney rank-sum test indicated larger postfire concentrations ( $\mathrm{p}$-value $<0.10$ ) for dissolved copper and total recoverable manganese (table 8) but not for other trace elements. No loads were significantly different. Some samples were not analyzed for certain trace elements in the prefire period.

\section{Comparison of Hayman and Hinman Fire Study Results}

Comparison of Hayman and Hinman water quality was done for the first full postfire year (2003). For the snowmeltdominated Lost Dog watershed in the Hinman fire area, the general lack of substantial rainfall to produce runoff in the late summer and fall of 2002 likely kept substantial constituent transport to a minimum during that unsampled period. For the Fourmile watershed in the Hayman fire area, the first flush of hillslope runoff in summer 2002 was missed because sampling began in April 2003. Generally, however, the rainstorm-influenced hydrology of the burned watershed (Fourmile 2003) in the
Hayman fire study area produced greater median concentrations (Mann-Whitney p-value $<0.10$ ) (figs. 24 and 25; table 9) of many water-quality constituents from postfire than the burned Lost Dog watershed (a similar watershed scale in the Hinman fire area) except for DOC, dissolved aluminum, and dissolved iron. Because the sampling at the Hayman area began in early April 2003, and storm runoff from the first flush of hillslope runoff probably contained high concentrations of water-quality constituents (Deborah Martin, U.S. Geological Survey, written commun., 2009), the interpretation of the significant (p-value $<0.10$ ) higher concentrations in the Fourmile watershed is most likely valid. Notably, however, many constituent concentrations were not significantly different between the two watersheds (p-value $<0.10$ ), including dissolved ammonia, dissolved and total ammonia plus organic nitrogen, dissolved phosphorus and orthophosphorus, total organic carbon, total recoverable aluminum, dissolved copper, total recoverable iron, dissolved and total manganese, and dissolved zinc. Some of these differences may have been significantly higher for Fourmile if runoff in late summer 2002 had been sampled.

Generally all median loads of constituents in the first postfire year (2003), normalized to drainage area, were greatest in the Lost Dog watershed of the Hinman fire (MannWhitney p-value $<0.10$ ), except for flow-weighted turbidity and UV absorption (table 9). This relation indicates that fireinduced effects on the export of water-quality constituents per unit of area may have had the greatest effect on the snowmeltdominated watershed of the Hinman fire area, which are probably a result of greater sustained, high streamflows. A low bias in the immediate postfire median loads in the Fourmile watershed may be present because no samples were collected in the summer 2002 first-flush period. The 2002 late summer stormflows at Fourmile did not leave substantial high-water marks and the duration of these flows resulting from thunderstorm activity is generally short; therefore, the resulting loads (streamflow-weighted concentrations) from these 2002 storms would be unlikely to change the interpretation of higher loads from the Lost Dog watershed.

\section{Temporal Trends}

Samples collected over a period of years following a wildfire may indicate temporal trends related to recovery. Based on available evidence in literature sources, disturbed hydrologic and biogeochemical systems of a watershed begin to recover after the fire and water-quality shifts toward the prefire condition over time by the reestablishment of vegetation, the breakdown of soil hydrophobic layers, and the flushing of water-quality constituents from the watershed that were mobilized by the fire. This recovery commonly resembles a steep decline or sometimes a quasi-exponential decrease after the first or second year postfire in stream runoff (Veenhuis, 2002), in hillslope particulate supply (Martin and Moody, 2001; MacDonald and Robichaud, 2008; Shaffrath, 2009), and in 
Table 9. Mann-Whitney test of postburn first-postfire year differences between Fourmile Creek (2003) and Lost Dog Creek (2003) water-quality measurements and constituent concentrations and instantaneous loads normalized to drainage area.

[Specific conductance, turbidity, and ultraviolet absorption at $254 \mathrm{~nm}$ are multiplied by streamflow but are not mass loads; -, no data; n, number of samples; shaded values indicate a larger median that is considered statistically significant for this report with a p-value less than or equal to $0.10 ; \mathrm{mg} / \mathrm{L}, \mathrm{milligrams} \mathrm{per} \mathrm{liter;} \mathrm{mi}^{2}$, square mile; $\mu \mathrm{g} / \mathrm{L}$, micrograms per liter; ${ }^{\circ} \mathrm{C}$, degrees Celsius; $\mathrm{ft}^{3} / \mathrm{s}$, cubic feet per second; $\mu \mathrm{S} / \mathrm{cm}$ at $25^{\circ} \mathrm{C}$, microsiemens per centimeter at $25^{\circ} \mathrm{C} ; \mu \mathrm{S}-\mathrm{ft}^{3} / \mathrm{cm} \mathrm{s} / \mathrm{mi}^{2}$, microsiemens cubic feet per centimeter seconds per square mile; $\mathrm{cm}^{-1}$, per centimeter; NTU-ft $\mathrm{f}^{3} / \mathrm{s}-\mathrm{mi}^{2}$, nephelometric turbidity units cubic feet per second square mile; $\mathrm{lb} / \mathrm{d} / \mathrm{mi}^{2}$, pounds per day per square mile; $\mathrm{CaCO}_{3}$, calcium carbonate; $\mathrm{N}$, nitrogen; $\mathrm{P}$, phosphorus; $\mathrm{C}$, carbon; nm, nanometers; $\mathrm{cm}$, centimeter; $\mathrm{lb} / \mathrm{d}$, pounds per day; $t / d$, tons per day; $t / d / \mathrm{mi}^{2}$, tons per day per square mile]

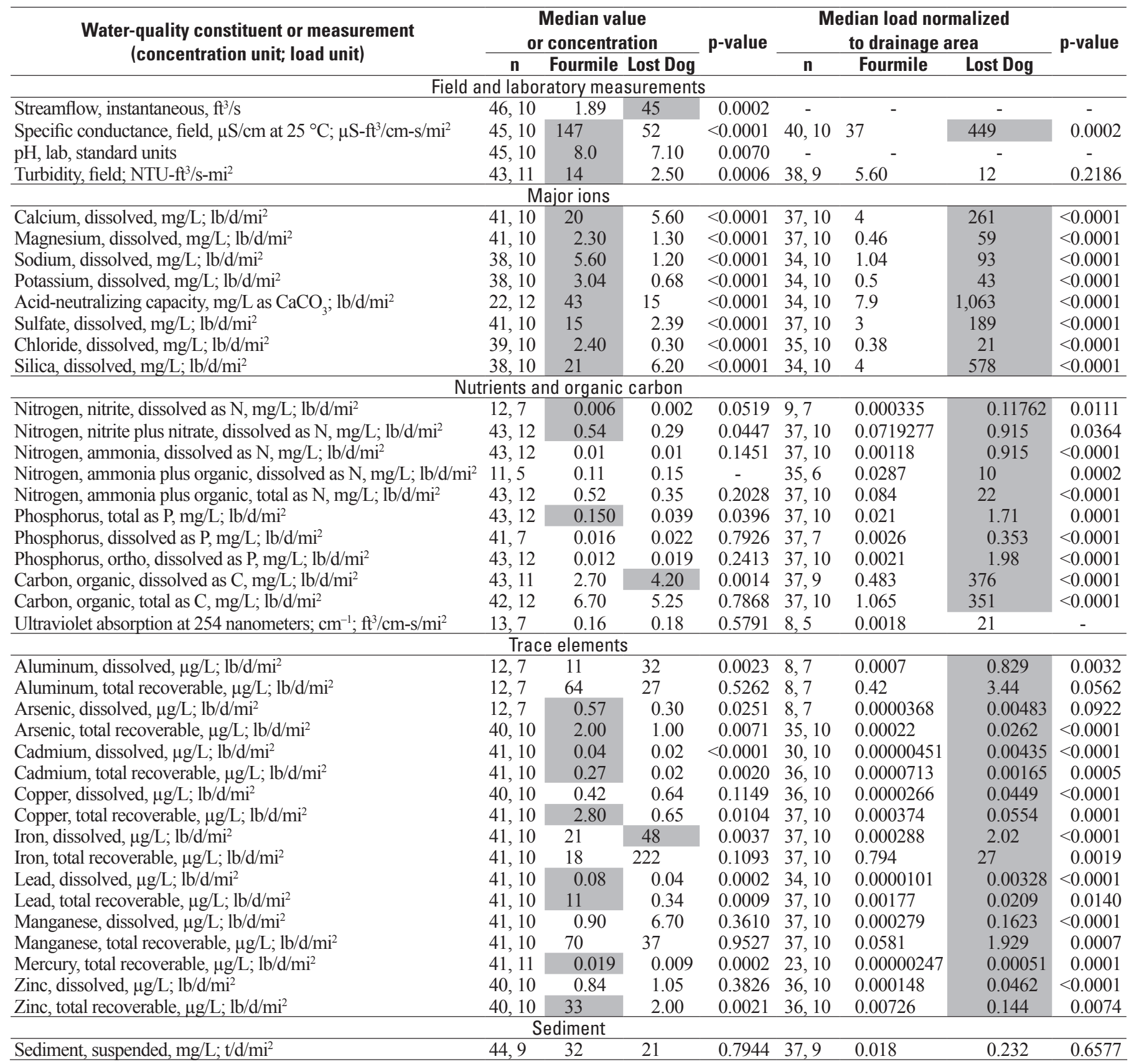


water-quality constituent concentrations (Ranalli, 2004; Hauer and Spencer, 1998; Gallaher and Koch, 2004). To investigate temporal trends, 5 years of water-quality concentrations and loads for Fourmile and Pine (post-Hayman fire) (figs. 26 and 27) were assessed using the seasonal Kendall test. Multiyear data were not collected following the Hinman fire, so temporal trends were not determined.

When concentrations at Fourmile were tested and a LOWESS streamflow adjustment was applied (table 4), downward trends (percent decrease per year over 5 years) were statistically significant ( $\mathrm{p}$-value $<0.10$ ) for specific conductance $(-7.3)$, calcium $(-11.8)$, magnesium $(-8.82)$, potassium $(-10.9)$, nitrite plus nitrate $(-17.4)$, total ammonia plus organic nitrogen $(-26.1)$, total phosphorus $(-37.5)$, dissolved phosphorus $(-25.6)$, dissolved organic carbon $(-8.90)$, total recoverable arsenic $(-31.0)$, dissolved copper $(-8.8)$, dissolved manganese $(-48.5)$, total recoverable manganese $(-30.5)$, and total recoverable mercury $(-30.6)$. However, a significant upward trend in silica concentration (+4.00) also was computed (table 4). When seasonal Kendall test was applied to loads (not streamflow-adjusted) at Fourmile, downward trends were significant ( $p$-value $<0.10$ ) only for dissolved manganese (-53.9), and no upward trends were computed (table 10). A lack of trends in load may be a result of confounding streamflow patterns that limited the effect of decreasing concentration on computed loads.

When values and concentrations were tested and adjusted for streamflow by using LOWESS at Pine (unburned reference site), temporal trends were downward and significant ( $\mathrm{p}$-value $<0.10)$ for total recoverable mercury $(-39.0)$ (table 5) and upward and significant for dissolved ammonia plus organic nitrogen $(+27.2)$, orthophosphorus $(+14.6)$, and dissolved organic carbon $(+12.8)$. When loads were tested but not streamflow-adjusted for Pine, temporal trends were downward and significant ( $p$-value $<0.10$ ) for total recoverable arsenic $(-35.1)$, dissolved manganese $(-41.0)$, and total recoverable mercury (-13.7) (table 11) and upward and significant for dissolved ammonia plus organic nitrogen $(+44.3)$, dissolved ammonia (+9.5), dissolved phosphorus (+9.0), dissolved orthophosphorus $(+16.3)$, dissolved cadmium $(+2.0)$, and dissolved lead (+13.6). Exact causes for these trends in the unburned Pine watershed are not known, but upward trends in loads may be related to some higher streamflows at the end of the 5-year period of analysis. Higher streamflows may indicate that increased soil-moisture flushing was the cause of upward trends in concentration for dissolved ammonia plus organic nitrogen, orthophosphorus, and DOC. Because smoke from the Hayman fire was blown to the northeast (over the Pine watershed) for much of the duration of the fire, particulates from smoke containing trace elements (Sillanpaa and others, 2005) such as arsenic, manganese, and mercury may have settled on the watershed. Downward trends in these trace elements at Pine may be the result of washout of these constituents following the Hayman fire.

\section{Loads Analysis}

Often the amount of a water-quality constituent transported over a period is just as important, or more so, than the concentration. In water-quality studies, the mass of a constituent transported in a stream during a unit of time past a particular point or reach is called the "load" and is commonly expressed in units of tons per day or pounds per day. The concept of loads of water-quality constituents is particularly important when load inputs to lakes or reservoirs need to be considered or a load allocation for total maximum daily load (TMDL) regulation is mandated for a reach of stream (U.S. Geological Survey, 2001).

In this study, seasonal (April through September) waterquality constituent loads were computed for the Hayman fire paired-watersheds and the South Platte Trumbull study site for 2003 (one year postfire) and for the Hinman prefire (1999) and postfire (2003) study sites. Loads were computed by using continuous streamflow records or estimated daily mean streamflows when streamflow record was not available. In Colorado, because most of the streamflow in mountainous areas occurs during the April-September period, it is likely that most of the annual load also was transported during this 6-month period. Load regressions for each constituent were computed using instantaneous concentrations and instantaneous streamflows at each site. A total seasonal load (April through September) was estimated by using the daily mean streamflows from each site in the load regressions and computing the sum of those loads for the 2003 season. The results of load computations were compared to evaluate both the mass of each constituent, the mass yield per unit of drainage area, and a volume-weighted load per unit of streamflow that approximates a streamflow-weighted concentration integrated over the April through September period (fig. 34 and table 12). Hydrograph comparison and regression techniques may add substantial potential uncertainty to these estimated loads.

\section{Hayman Fire Study Area}

Estimated seasonal loads, normalized to drainage area, at Fourmile and Pine for 2003, indicated that loads at Fourmile (figs. 35A-H; table 12) for potassium, total nitrogen, nitrite plus nitrate, TOC, total phosphorus, orthophosphorus, and total manganese were much larger than loads at Pine. Insufficient uncensored results at Pine for total recoverable mercury prevented a comparison of loads for that constituent (fig. 35G). As mentioned previously, no samples were collected in late summer 2002 at Fourmile, which may have excluded the postfire first-flush load. Total or total recoverable constituent loads were usually one or more orders of magnitude larger at Fourmile. Dissolved constituent loads (potassium, nitrite plus nitrate, orthophosphorus) were several times larger but not by more than an order of magnitude (figs. $35 \mathrm{~A}$, $C, E$; table 12). 
Table 10. Seasonal Kendall trend-analysis results for streamflow-weighted water-quality measurements and constituent loads (not LOWESS-adjusted for streamflow) at Fourmile Creek (2003-2007).

[Specific conductance and turbidity are multiplied by streamflow but are not mass loads; --, insufficient data; n, number of samples; shaded values indicate a statistically significant trend for this report with a p-value less than or equal to 0.10 ; up, statistically significant trend increasing over the period of analysis; down, statistically significant trend decreasing over the period of analysis; $\mathrm{mg} / \mathrm{L}$, milligrams per liter; $\mu \mathrm{g} / \mathrm{L}$, micrograms per liter; ${ }^{\circ} \mathrm{C}$, degrees $\mathrm{Celsius} \mathrm{ft}^{3} / \mathrm{s}$, cubic feet per second; $\mu \mathrm{S} / \mathrm{cm}$ at $25^{\circ} \mathrm{C}$, microsiemens per centimeter at $25^{\circ} \mathrm{C} ; \mu \mathrm{S}-\mathrm{ft}^{3} / \mathrm{cm}-\mathrm{s} / \mathrm{mi}^{2}$, microsiemens cubic feet per centimeter seconds per square mile; $\mathrm{NTU}-\mathrm{ft}^{3} / \mathrm{s}-\mathrm{mi}^{2}$, nephelometric turbidity units cubic feet per second square mile; $1 \mathrm{~b} / \mathrm{d} / \mathrm{mi}^{2}$, pounds per day per square mile; NTU, nephelometric turbidity units; $\mathrm{CaCO}_{3}$, calcium carbonate; $\mathrm{N}$, nitrogen; $\mathrm{P}$, phosphorus; $\mathrm{C}$, carbon; $\mathrm{nm}$, nanometers; $\mathrm{cm}$, centimeter; $\mathrm{lb} / \mathrm{d}$, pounds per day; $\mathrm{t} / \mathrm{d}$, tons per day, $\mathrm{t} / \mathrm{d} / \mathrm{mi}^{2}$, tons per day per square mile]

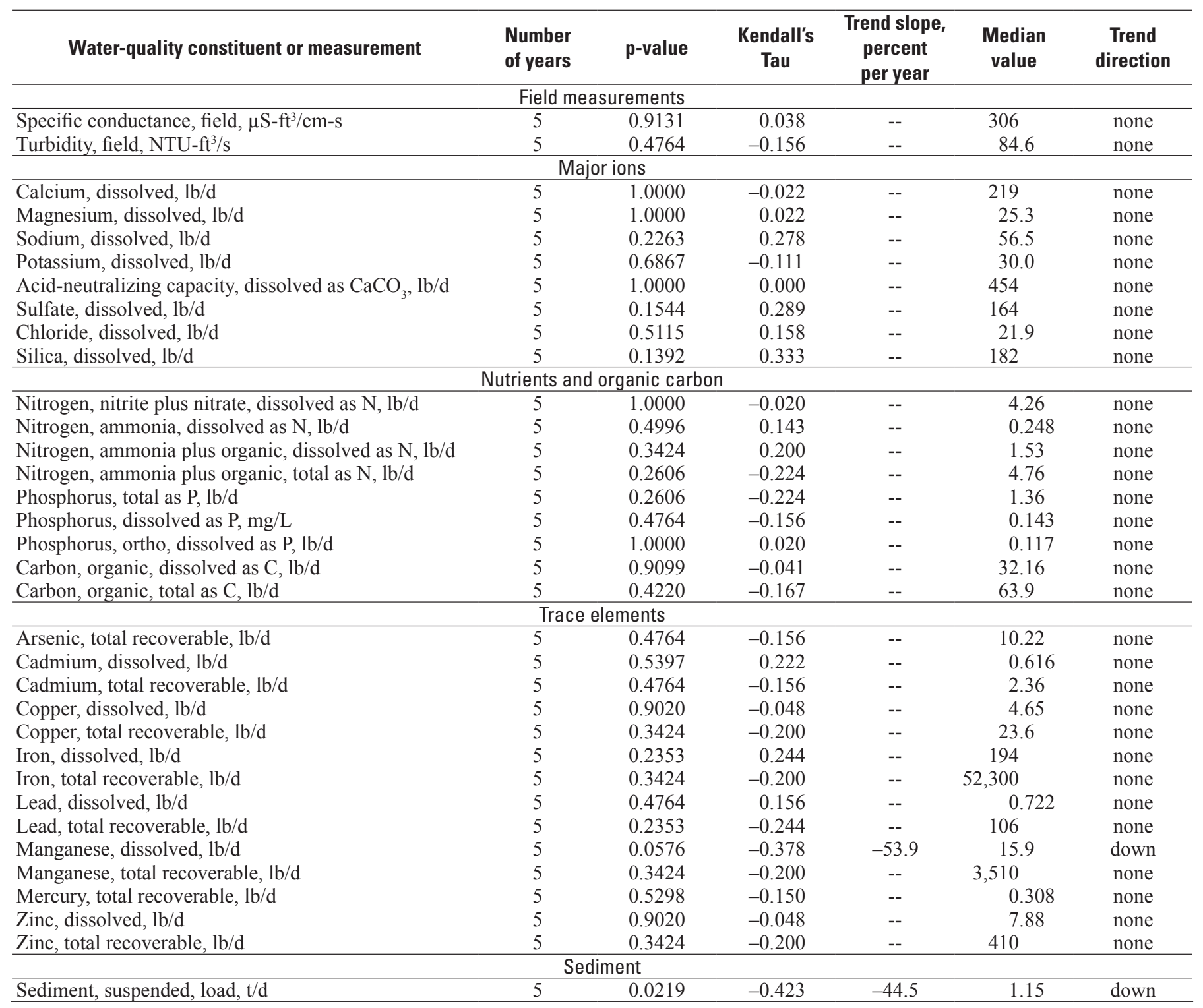


Table 11. Seasonal Kendall trend-analysis results for streamflow-weighted water-quality measurements and constituent loads (not LOWESS-adjusted for streamflow) at Pine Creek (2003-2007).

[Specific conductance and turbidity are multiplied by streamflow but are not mass loads; --, insufficient data; $n$, number of samples; shaded values indicate a statistically significant trend for this report with a p-value less than or equal to 0.10 ; up, statistically significant trend increasing over the period of analysis; down, statistically significant trend decreasing over the period of analysis; $\mathrm{mg} / \mathrm{L}$, milligrams per liter; $\mu \mathrm{g} / \mathrm{L}$, micrograms per liter; ${ }^{\circ} \mathrm{C}$, degrees Celsius; $\mathrm{ft}^{3} / \mathrm{s}$, cubic feet per second; $\mu \mathrm{S} / \mathrm{cm}$ at $25^{\circ} \mathrm{C}$, microsiemens per centimeter at $25^{\circ} \mathrm{C} ; \mu \mathrm{S}-\mathrm{ft}^{3} / \mathrm{cm}-\mathrm{s} / \mathrm{mi}^{2}$, microsiemens cubic feet per centimeter seconds per square mile; NTU-ft $\mathrm{ft}^{3} / \mathrm{s}-\mathrm{mi}{ }^{2}$, nephelometric turbidity units cubic feet per second square mile; $1 \mathrm{~b} / \mathrm{d} / \mathrm{mi}^{2}$, pounds per day per square mile; $\mathrm{CaCO}_{3}$, calcium carbonate; $\mathrm{N}$, nitrogen; $\mathrm{P}$, phosphorus; $\mathrm{C}$, carbon; $\mathrm{nm}$, nanometers; $\mathrm{cm}$, centimeter; $\mathrm{lb} / \mathrm{d}$, pounds per day; $\mathrm{t} / \mathrm{d}$, tons per day; $\mathrm{t} / \mathrm{d} / \mathrm{mi}^{2}$, tons per day per square mile]

\begin{tabular}{|c|c|c|c|c|c|c|}
\hline Water-quality constituent or measurement & $\begin{array}{l}\text { Number } \\
\text { of years }\end{array}$ & p-value & $\begin{array}{c}\text { Kendall's } \\
\text { Tau }\end{array}$ & $\begin{array}{c}\text { Trend slope, } \\
\text { percent } \\
\text { per year }\end{array}$ & $\begin{array}{c}\text { Median } \\
\text { value }\end{array}$ & $\begin{array}{c}\text { Trend } \\
\text { direction }\end{array}$ \\
\hline \multicolumn{7}{|c|}{ Field measurements } \\
\hline Turbidity, field, NTU-ft ${ }^{3} / \mathrm{s}$ & 5 & 1.0000 & -0.022 & -- & 0.948 & none \\
\hline \multicolumn{7}{|c|}{ Major ions } \\
\hline Calcium, dissolved, lb/d & 5 & 0.3424 & 0.200 & -- & 44.9 & none \\
\hline Potassium, dissolved, $\mathrm{lb} / \mathrm{d}$ & 4 & -- & -- & -- & -- & -- \\
\hline Acid-neutralizing capacity, dissolved as $\mathrm{CaCO}_{3}, \mathrm{lb} / \mathrm{d}$ & 4 & -- & -- & -- & -- & -- \\
\hline Sulfate, dissolved as, $\mathrm{lb} / \mathrm{d}$ & 5 & 0.8124 & 0.067 & -- & 31.8 & none \\
\hline Chloride, dissolved, $\mathrm{lb} / \mathrm{d}$ & 5 & 0.5224 & -0.222 & -- & 4.27 & none \\
\hline Silica, dissolved, $\mathrm{lb} / \mathrm{d}$ & 4 & -- & -- & -- & -- & -- \\
\hline \multicolumn{7}{|c|}{ Nutrients and organic carbon } \\
\hline Phosphorus, ortho, dissolved as $\mathrm{P}, \mathrm{lb} / \mathrm{d}$ & 5 & 0.0069 & 0.510 & 16.3 & 0.011 & up \\
\hline Phosphorus, dissolved as $\mathrm{P}, \mathrm{lb} / \mathrm{d}$ & 5 & 0.0966 & 0.333 & 9.0 & 0.016 & up \\
\hline Phosphorus, total as $\mathrm{P}, \mathrm{lb} / \mathrm{d}$ & 5 & 0.2606 & 0.224 & -- & 0.029 & none \\
\hline Carbon, organic, dissolved as $\mathrm{C}, \mathrm{lb} / \mathrm{d}$ & 5 & 0.1770 & 0.265 & -- & 8.14 & none \\
\hline Carbon, organic, total as $\mathrm{C}, \mathrm{lb} / \mathrm{d}$ & 4 & -- & -- & -- & -- & -- \\
\hline \multicolumn{7}{|c|}{ Trace elements } \\
\hline Arsenic, total recoverable, lb/d & 5 & 0.0004 & -0.689 & -35.1 & 0.002 & down \\
\hline Cadmium, dissolved, $\mathrm{lb} / \mathrm{d}$ & 5 & 0.0090 & 0.511 & 2.0 & 0.0001 & up \\
\hline Cadmium, total recoverable, $\mathrm{lb} / \mathrm{d}$ & 5 & 1.0000 & 0.022 & -- & 0.0001 & none \\
\hline Copper, dissolved, lb/d & 5 & 0.8124 & -0.067 & -- & 0.002 & none \\
\hline Copper, total recoverable, $\mathrm{lb} / \mathrm{d}$ & 5 & 0.8124 & -0.067 & -- & 0.002 & none \\
\hline Iron, dissolved, lb/d & 5 & 1.0000 & 0.022 & -- & 0.030 & none \\
\hline \multicolumn{7}{|c|}{ Sediment } \\
\hline Sediment, suspended, discharge, T/d & 5 & 0.5663 & -0.125 & -- & 0.007 & none \\
\hline
\end{tabular}



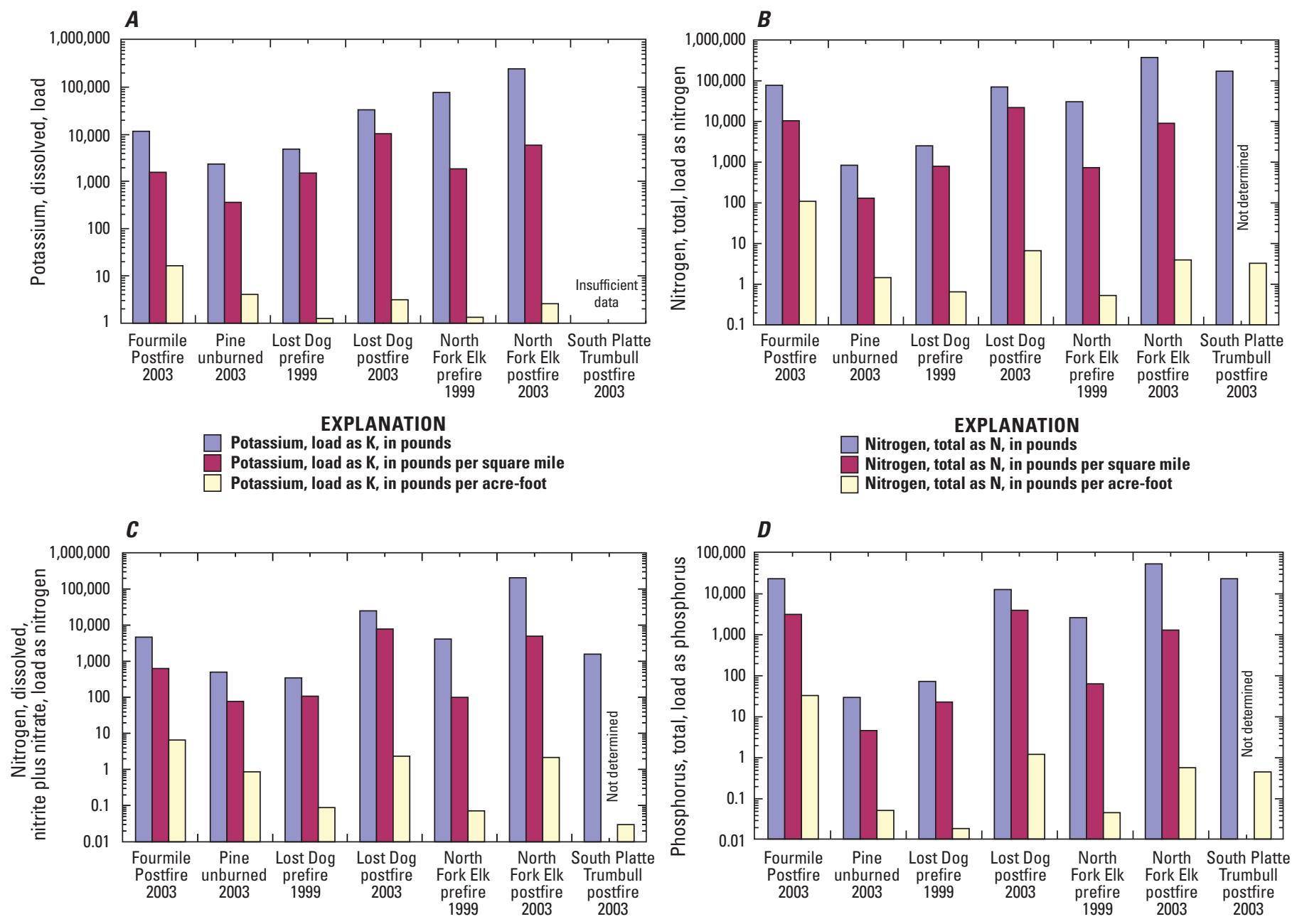

EXPLANATION

$\square$ Nitrogen, nitrite plus nitrate, load as $\mathrm{N}$, in pounds

Nitrogen, nitrite plus nitrate, load as $\mathrm{N}$, in pounds per square mile

Nitrogen, nitrite plus nitrate, load as $\mathrm{N}$, in pounds per acre-foot

EXPLANATION

Phosphorus, total as $P$, load, in pounds

Phosphorus, total as $P$, load, in pounds per square mile

Phosphorus, load as $P$, load, in pounds per acre-foot
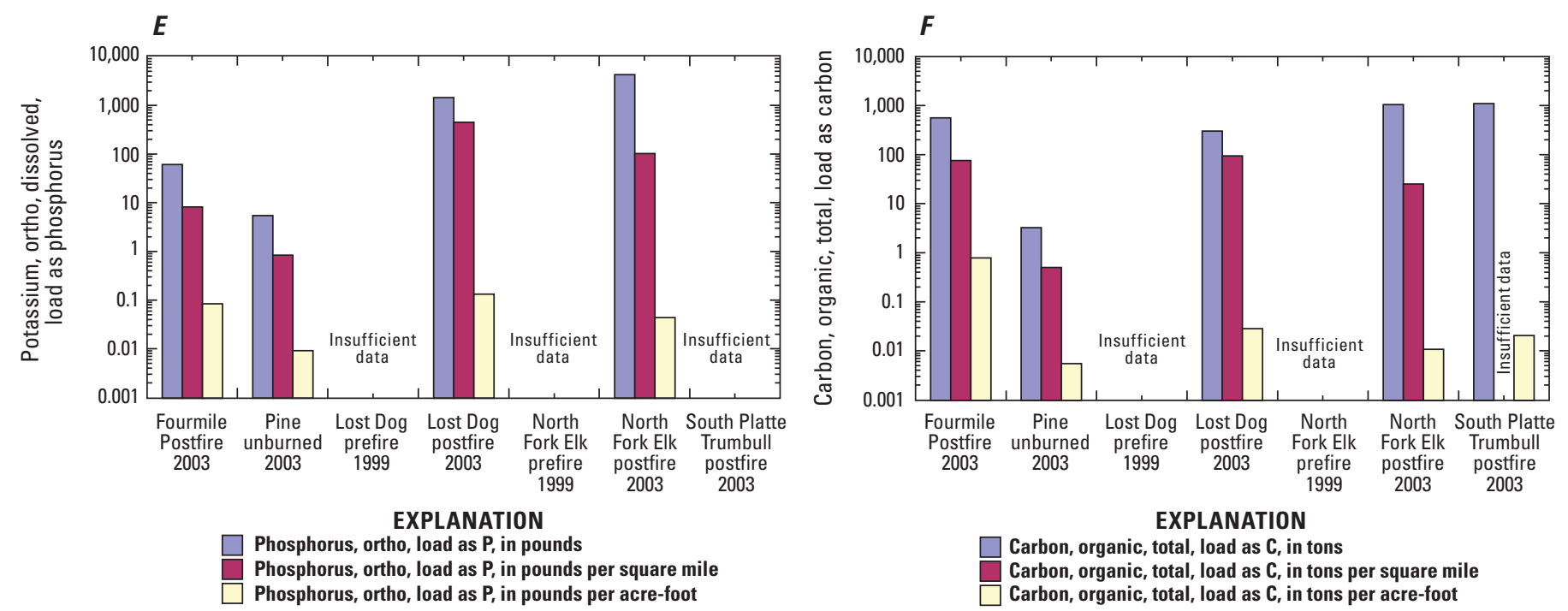

Figure 34. Graphs showing loads of selected water-quality constituents computed for the April through September period during 1999 and 2003 at North Fork Elk River, and Lost Dog Creek and the April through September period during 2003 at Fourmile Creek, Pine Creek, and South Platte River near Trumbull. 


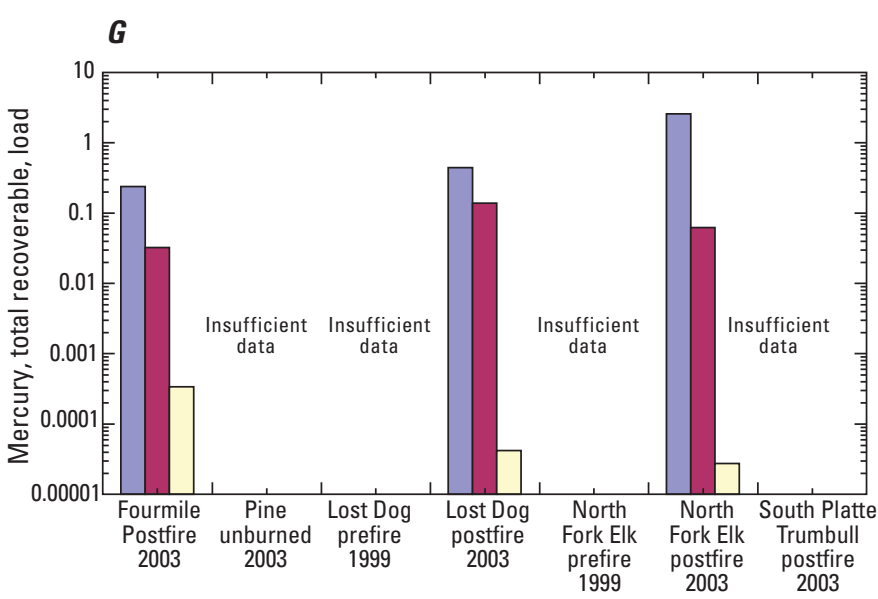

EXPLANATION

Mercury, total recoverable, load as $\mathrm{Hg}$, in pounds

Mercury, total recoverable, load as $\mathrm{Hg}$, in pounds per square mile

Mercury, total recoverable, load as $\mathrm{Hg}$, in pounds per acre-foot

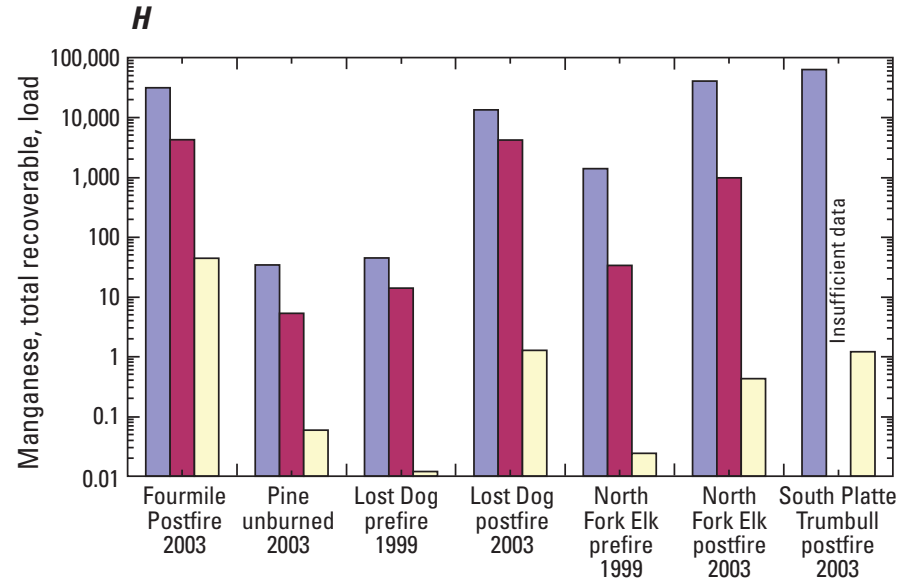

EXPLANATION

Manganese, total recoverable, load as $\mathrm{Mn}$, in pounds

Manganese, total recoverable, load as $\mathrm{Mn}$, in pounds per square mile

Manganese, total recoverable, load as $\mathrm{Mn}$, in pounds per acre-foot

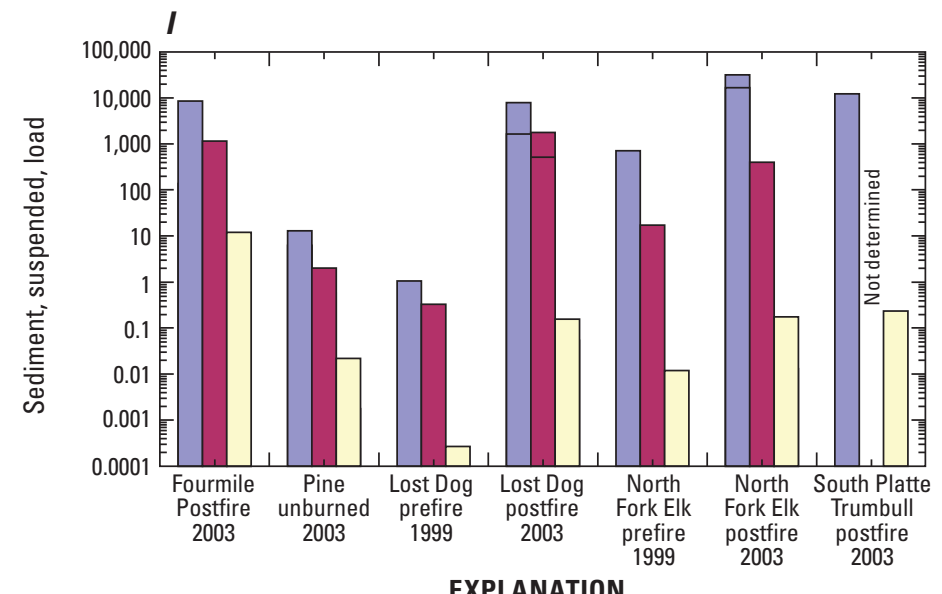

EXPLANATION

Sediment, suspended, load, in tons

Sediment, suspended, load, in tons per square mile

Sediment, suspended, load, in tons per acre-foot

Figure 34. Graphs showing loads of selected water-quality constituents computed for the April through September period during 1999 and 2003 at North Fork Elk River, and Lost Dog Creek and the April through September period during 2003 at Fourmile Creek, Pine Creek, and South Platte River near Trumbull._-Continued 
Table 12. Selected water-quality constituent loads for the April through September 2003 period at Fourmile Creek and Pine Creek and the 1999 and 2003 periods at North Fork Elk River and Lost Dog Creek.

[--, insufficient data; water-quality constituent not measured or load regression was not adequate for computations; $\mathrm{N}$, nitrogen; P, phosphorus; C, carbon; total nitrogen was computed for the regression data by summing the total ammonia plus organic nitrogen and the nitrite plus nitrate concentrations and calculating the load]

\begin{tabular}{|c|c|c|c|c|c|c|c|c|c|}
\hline Site, burn status, year & $\begin{array}{c}\text { Potassium, } \\
\text { dissolved }\end{array}$ & $\begin{array}{l}\text { Nitrogen, } \\
\text { total as N }\end{array}$ & $\begin{array}{c}\text { Nitrite plus } \\
\text { nitrate, } \\
\text { total as N } \\
\end{array}$ & $\begin{array}{c}\text { Carbon, } \\
\text { organic, } \\
\text { total as C }\end{array}$ & $\begin{array}{c}\text { Phosphorus, } \\
\text { total as P }\end{array}$ & $\begin{array}{c}\text { Phosphorus, } \\
\text { ortho, } \\
\text { dissolved as P }\end{array}$ & $\begin{array}{c}\text { Manganese, } \\
\text { total } \\
\text { recoverable }\end{array}$ & $\begin{array}{c}\text { Mercury, } \\
\text { total } \\
\text { recoverable }\end{array}$ & $\begin{array}{l}\text { Sediment, } \\
\text { suspended }\end{array}$ \\
\hline \multicolumn{10}{|c|}{ Load, pounds (sediment and total organic carbon, in tons) } \\
\hline Fourmile Creek postfire 2003 & 11,600 & 77,000 & 4,670 & 564 & 22,700 & 61 & 31,300 & 0.242 & 8,540 \\
\hline Pine Creek unburned 2003 & 3,160 & 1,290 & 843 & 4.68 & 41.4 & 7.35 & 54.4 & -- & 20.7 \\
\hline Lost Dog Creek prefire 1999 & 4,870 & 2,520 & 346 & -- & 70.7 & -- & 44.8 & -- & 1.06 \\
\hline Lost Dog Creek postfire 2003 & 33,100 & 70,200 & 25,000 & 303 & 12,300 & 1,440 & 13,410 & 0.447 & 1,650 \\
\hline North Fork Elk River prefire 1999 & 77,000 & 30,400 & 4,140 & -- & 2,550 & - & 1,390 & -- & 714 \\
\hline North Fork Elk River postfire 2003 & 245,000 & 373,000 & 205,000 & 1,050 & 52,300 & 4,280 & 40,460 & 2.59 & 16,700 \\
\hline South Platte River near Trumbull 2003 & -- & 171,000 & 1,574 & 1,100 & 22,700 & -- & 63,300 & - & 12,300 \\
\hline \multicolumn{10}{|c|}{ Loads normalized to drainage area, pounds per square mile (sediment and total organic carbon, in tons per square mile) } \\
\hline Fourmile Creek postfire 2003 & 1,580 & 10,400 & 631 & 76.2 & 3,070 & 8.24 & 4,230 & 0.033 & 1,160 \\
\hline Pine Creek unburned 2003 & 490 & 199 & 131 & 0.725 & 6.43 & 1.14 & 8.43 & -- & 3.22 \\
\hline Lost Dog Creek prefire 1999 & 1,520 & 789 & 108 & -- & 22.1 & -- & 14 & -- & 0.331 \\
\hline Lost Dog Creek postfire 2003 & 10,360 & 21,900 & 7,800 & 94.7 & 3,860 & 450 & 4,190 & 0.140 & 517 \\
\hline North Fork Elk River prefire 1999 & 1,860 & 734 & 100 & -- & 61.5 & -- & 33.6 & -- & 17.2 \\
\hline North Fork Elk River postfire 2003 & 5,920 & 9,010 & 4,950 & 25.4 & 1,260 & 103. & 977 & 0.063 & 403 \\
\hline South Platte River near Trumbull 2003 & -- & -- & -- & -- & -- & -- & -- & -- & -- \\
\hline \multicolumn{10}{|c|}{ Yields, pounds per acre-ft (sediment and total organic carbon, in tons per acre-ft) } \\
\hline Fourmile Creek postfire 2003 & 16.5 & 109 & 6.59 & 0.797 & 32.0 & 0.086 & 44.2 & 0.00034 & 12.1 \\
\hline Pine Creek unburned 2003 & 3.90 & 1.59 & 1.04 & 0.006 & 0.051 & 0.009 & 0.067 & -- & 0.026 \\
\hline Lost Dog Creek prefire 1999 & 1.26 & 0.651 & 0.089 & -- & 0.018 & -- & 0.012 & -- & 0.0003 \\
\hline Lost Dog Creek postfire 2003 & 3.14 & 6.65 & 2.36 & 0.029 & 1.17 & 0.136 & 1.27 & 0.00004 & 0.157 \\
\hline North Fork Elk River prefire 1999 & 1.34 & 0.529 & 0.072 & -- & 0.044 & -- & 24.2 & -- & 0.012 \\
\hline North Fork Elk River postfire 2003 & 2.59 & 3.94 & 2.17 & 0.011 & 0.552 & 0.045 & 427 & 0.00003 & 0.176 \\
\hline South Platte River near Trumbull 2003 & -- & 3.27 & 0.0301 & 0.021 & 0.434 & -- & 1.20 & - & 0.236 \\
\hline
\end{tabular}




\section{Hinman Fire Study Area}

Estimated seasonal water-quality constituent loads at Lost Dog and North Fork Elk for prefire (1999-2000) and postfire (2003) were computed. No prefire data were available for orthophosphorus, DOC, and total recoverable mercury for Lost Dog and North Fork Elk. The results indicate that postfire total loads normalized to drainage area (fig. 34; table 12) were much larger than prefire loads for potassium, total nitrogen, nitrite plus nitrate, total phosphorus, and total manganese. Similar to the Fourmile-Pine comparison, total or total recoverable constituents were generally one or more orders of magnitude larger during postfire. Dissolved constituents (potassium and nitrite plus nitrate) were several times larger but not by more than an order of magnitude (figs. $34 A, C$; table 12).

\section{Comparison of Hayman and Hinman Fire Study Results}

When total seasonal loads (normalized to drainage area) were compared among the burned watersheds evaluated in both the Hayman fire and Hinman fire study areas, no postfire loads at Fourmile (Hayman) were larger except for total recoverable manganese, which was similar to Lost Dog (Hinman) (fig. 34; table 12). Some of these loads could also be higher in the Hinman area as a result of nutrient cycling from the Routt blowdown in addition to the effects of fire. Among the unburned site loads (Pine, Lost Dog, North Fork Elk), Pine (Hayman) generally had the smallest constituent loads per square mile (fig. 34). As mentioned previously, no samples were collected in late summer 2002 at Fourmile, which may have excluded a part of the postfire first-flush load and may render the implication that the snowmelt-dominated setting yields greater unit loads than the rainfall-affected setting inconclusive.

\section{Sediment Transport}

\section{Sources and Storage}

Field observations indicated that postfire sediment originated from a variety of sources in the Hayman and Hinman fire areas. In the Hayman fire study area, overland flow during rainfall events during the first postfire year (2003) was observed but was not as common in later years (fig. 35A). On burned hillslopes, coalescing, small rills joined, forming larger rills, and even small, incised gullies that reached small streams were observed. High, postfire streamflows had substantial effects on stream channel-bed and streambank stability (figs. $35 B$ to $35 E$ ). Downcutting of stream channel beds and channel widening was common in larger burned watersheds tributary to the South Platte River. In the Hinman fire area, overland flow was observed during snowmelt (2003) in swales and gullies that would not support substantial overland flow in unburned conditions. The extreme postfire streamflow response in small streams in the Hinman fire area resulted in water overtopping streambanks, which washed away fine-grained soil and organic matter. However, channel and streambank instability did not occur nearly to the same degree that occurred in burned watersheds of the Hayman fire, which may be related to the coarser sediments (large amounts of cobble-boulder sized material) in the Hinman fire area.

Lakes, reservoirs, and beaver ponds can accumulate sediment and complicate watershed sediment-yield computations by reducing downstream transport. Many watersheds in the study areas probably are affected by beaver ponds, which detained some sediment at least in the short-term (fig. 35F). In the Fourmile watershed, a number of private ponds in the upper watershed and a swimming and (or) boating pond at the YMCA Camp Shady Brook (fig. 35G) also retained water and sediment. Some sediment also accumulated at the mouths of small ephemeral drainages as alluvial fans (fig. $35 H$ ). Field observations indicated that trunk streams erode the sediment stored on some alluvial fans near the Hayman fire study area (figs. 35I and 35J).

\section{Comparisons of Burned and Unburned Study Areas}

\section{Hayman Fire Study Area}

Suspended sediment is defined as the particles (mostly rock fragments, soil, and some organic material) suspended in the water column by water turbulence. Suspended-sediment discharge usually is only a portion of the total-sediment discharge, which also includes the bedload. Bedload is the sediment transported by bouncing, rolling, and skidding along the streambed; bedload measurements, however, were beyond the scope of this study.

The distribution of suspended-sediment concentrations indicates that Fourmile had much larger concentrations than Pine (fig. 36). Suspended-sediment concentrations in samples ranged from less than 1 to $83 \mathrm{mg} / \mathrm{L}$ at Pine (unburned watershed) and from 4 to $55,000 \mathrm{mg} / \mathrm{L}$ at Fourmile (burned watershed) (fig. 37) (appendix 2). Streamflow resulting from rainstorm runoff contained the largest suspended-sediment concentrations at Fourmile, but no comparable storm-runoff events were observed at Pine. Suspended-sediment samples collected from both Fourmile and Pine tended to be fine grained, which facilitated sediment transport. The median percentage of silt and clay (particles finer than 0.062 millimeter) in suspended-sediment samples analyzed for size fractions from Fourmile was 65 percent, and 79 percent from Pine (appendix 2). The median load of suspended sediment at Fourmile was 1.2 tons per day, at Pine 0.0067 ton per day. Comparison of paired instantaneous suspended-sediment concentration and load at Fourmile and Pine using the Wilcoxon signed-rank test indicated larger values at Fourmile ( $\mathrm{p}$-value $<0.10$ ) (table 3). Despite the findings by other research (Pietraszek, 2006; MacDonald and Robichaud, 2008, that 

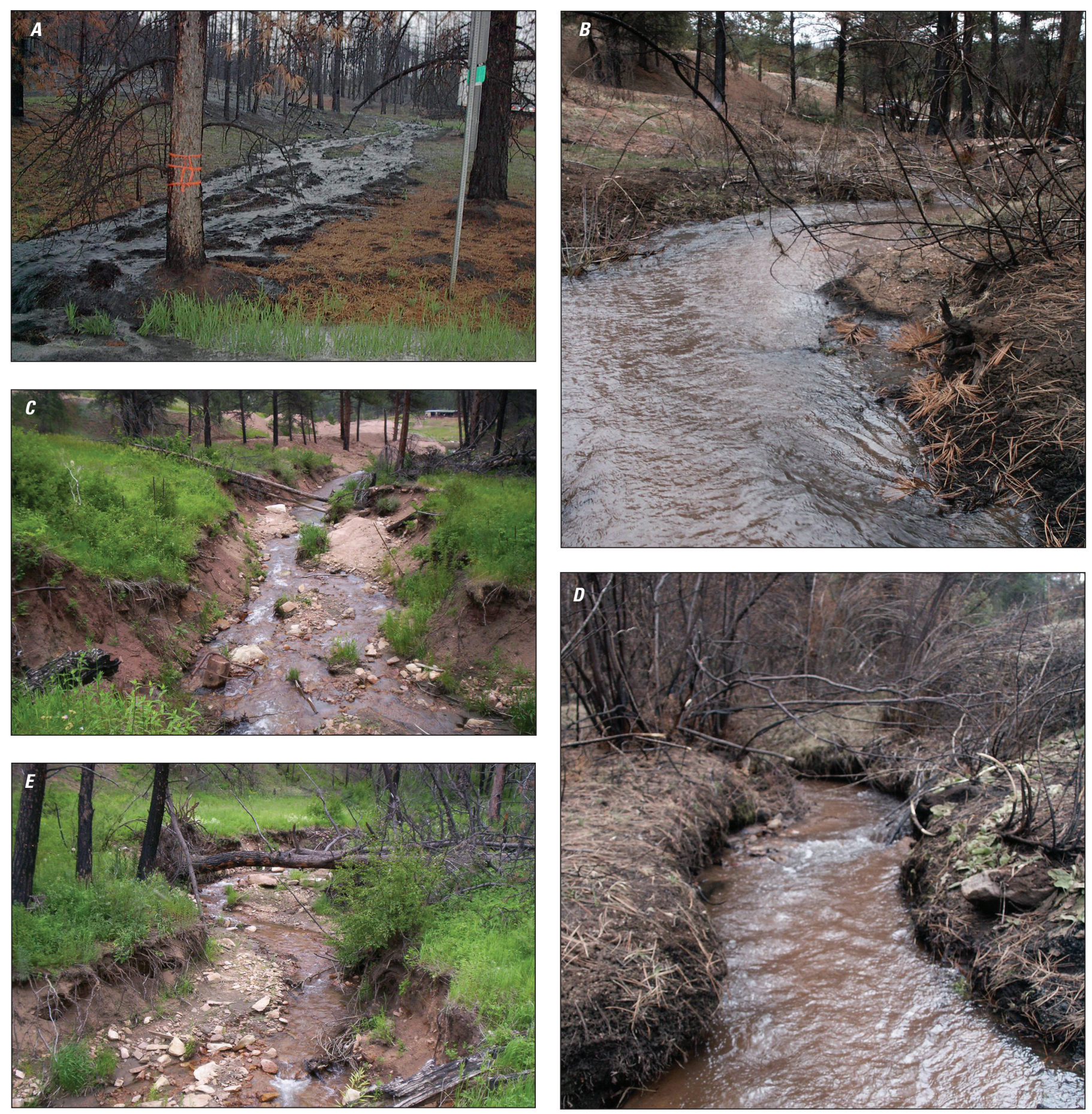

Figure 35. Photographs showing sediment sources and storage, Hayman fire area. $A$, overland hillslope runoff from rainstorm on May 30, 2003, near West Creek, Colorado (Photograph taken by Richard Ommert, Anderson and Associates Engineering, used with permission); $B$, Fourmile Creek downstream view before substantial channel erosion on April 21, 2003; $C$, channel incision and streambank widening at Fourmile Creek on June 28, 2007, view downstream same reach as B; $D$, Fourmile Creek upstream view before substantial channel erosion on April 21, 2003; E, channel incision and streambank widening at Fourmile Creek on June 28, 2007, view upstream same reach as D; $F$, sediment-filled beaver pond on Shrewsbury Gulch near West Creek, Colo. (Photograph taken by Richard Ommert, Anderson and Associates Engineering, used with permission); G, coarse sediments accumulating at inflow of Fourmile Creek into Kiwanis Lake at YMCA Camp Shady Brook on September 29, 2003; H, alluvial fan on lower Trail Creek near West Creek, Colo. on July 12, 2006; I, alluvial fan on Fourmile Creek downstream from YMCA Camp Shady Brook on August 31, 2007; and J, alluvial fan at mouth of Saloon Gulch at South Platte River downstream from Trumbull, Colo., on July 23, 2002 (Photograph taken by John Elliott, U.S. Geological Survey, used with permission). (All photographs by author, unless otherwise identified). 

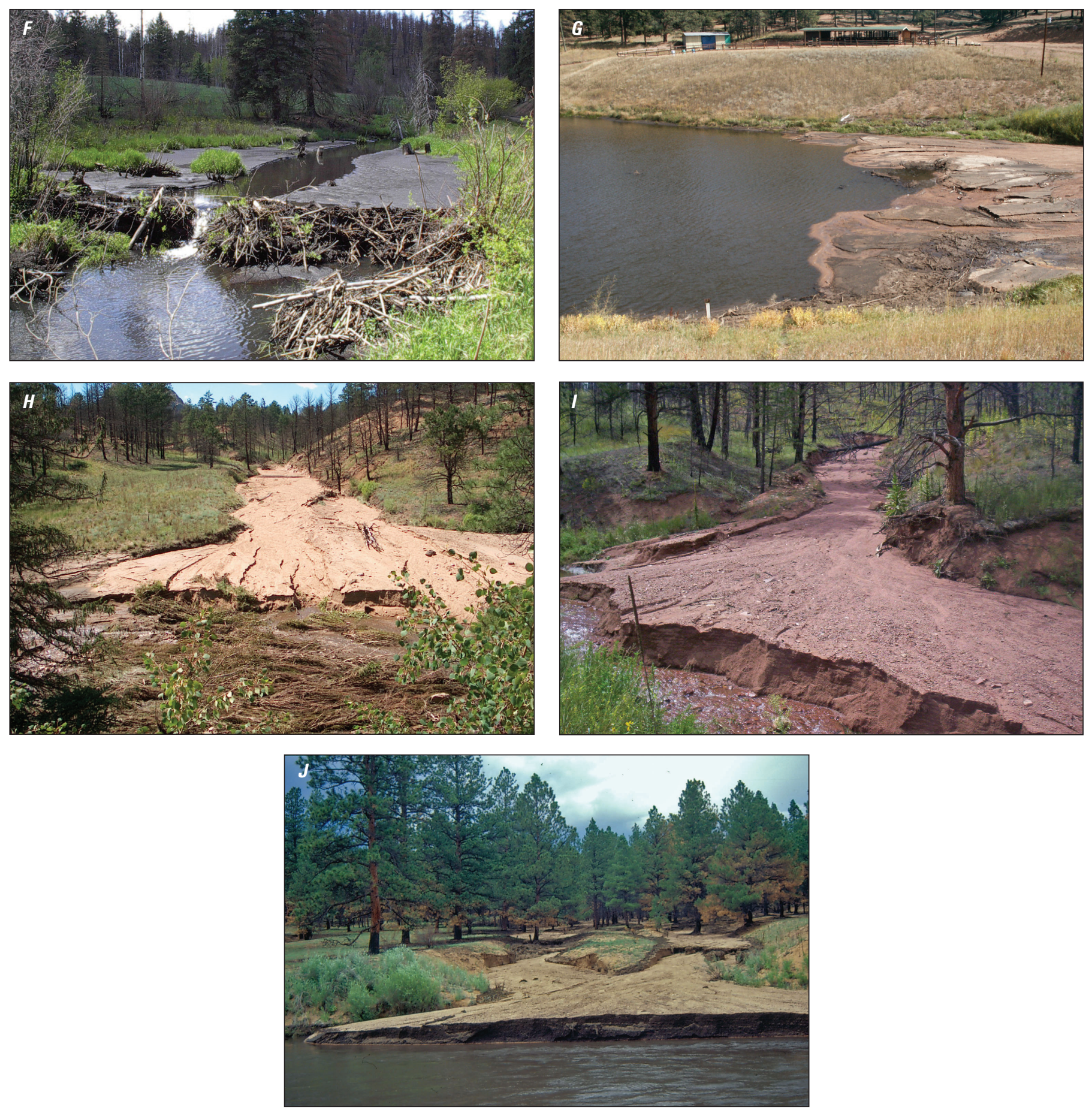

Figure 35. Photographs showing sediment sources and storage, Hayman fire area. $A$, overland hillslope runoff from rainstorm on May 30, 2003, near West Creek, Colorado (Photograph taken by Richard Ommert, Anderson and Associates Engineering, used with permission); $B$, Fourmile Creek downstream view before substantial channel erosion on April 21, 2003; $C$, channel incision and streambank widening at Fourmile Creek on June 28, 2007, view downstream same reach as $B ; D$, Fourmile Creek upstream view before substantial channel erosion on April 21, 2003; E, channel incision and streambank widening at Fourmile Creek on June 28, 2007, view upstream same reach as $D$; $F$, sediment-filled beaver pond on Shrewsbury Gulch near West Creek, Colo. (Photograph taken by Richard Ommert, Anderson and Associates Engineering, used with permission); $G$, coarse sediments accumulating at inflow of Fourmile Creek into Kiwanis Lake at YMCA Camp Shady Brook on September 29, 2003; H, alluvial fan on lower Trail Creek near West Creek, Colo. on July 12, 2006; I, alluvial fan on Fourmile Creek downstream from YMCA Camp Shady Brook on August 31, 2007; and $J$, alluvial fan at mouth of Saloon Gulch at South Platte River downstream from Trumbull, Colo., on July 23, 2002 (Photograph taken by John Elliott, U.S. Geological Survey, used with permission). (All photographs by author, unless otherwise identified).-Continued 


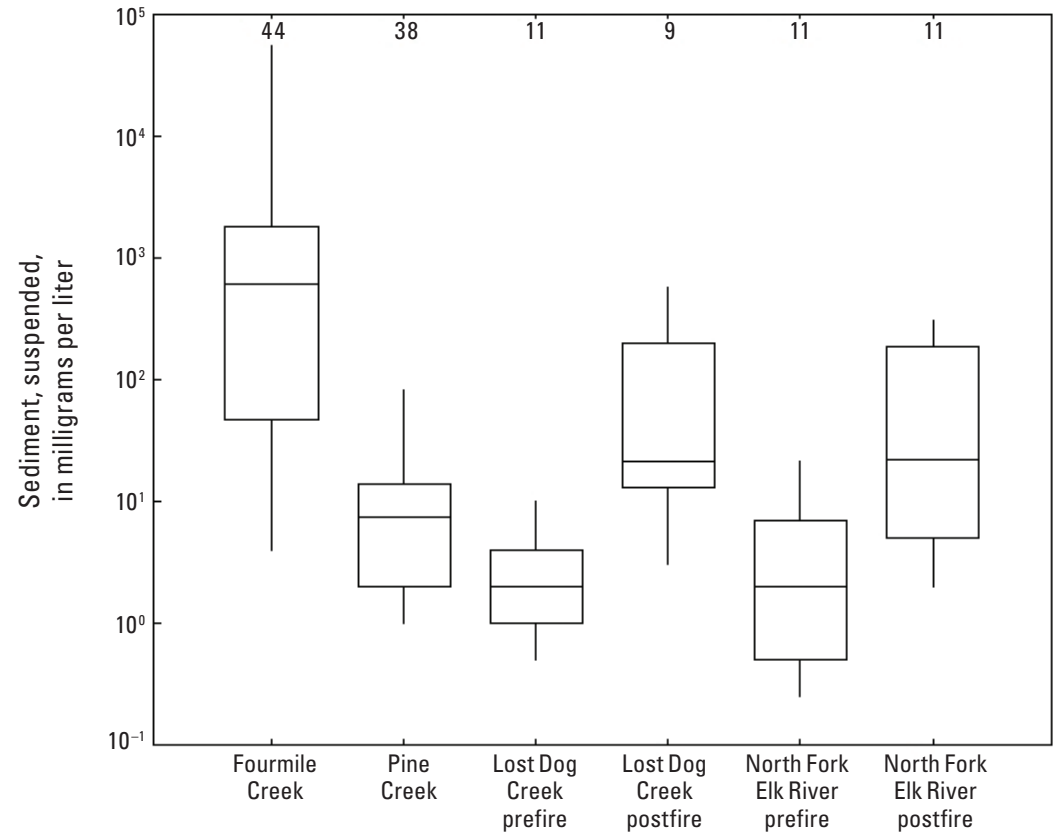

EXPLANATION

Schematic boxplot

30 Number of values

- Upper detached

$x$ Upper outside

Upper adjacent

75th percentile

Median

25th percentile

Lower adjacent

$x$ Lower outside

- Lower detached

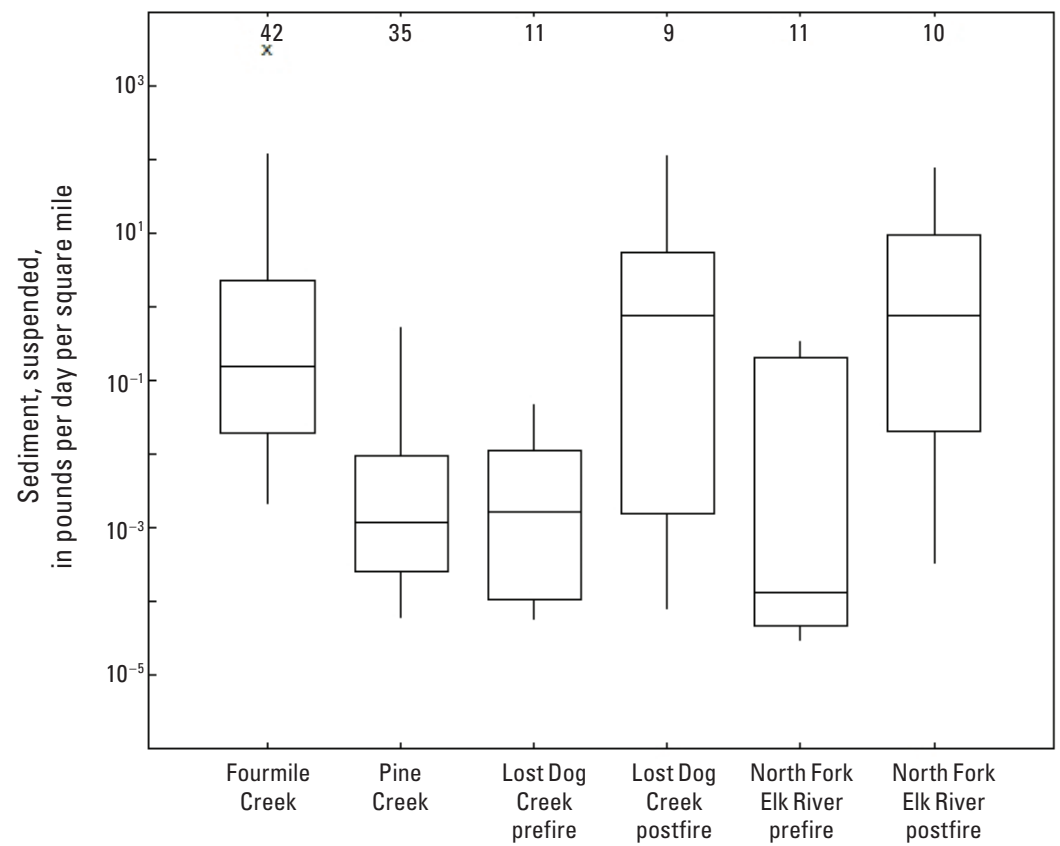

Figure 36. Boxplots showing comparison of suspended-sediment concentrations and loads for all sites.

snowmelt produces very little sediment erosion at the hillslope scale (a result of minor overland flow), in the Hayman burn area large suspended-sediment loads were transported in Fourmile during snowmelt periods (appendix 1), probably as a result of streambed and streambank erosion.

Another measure of sediment load that may represent more of the total sediment load from Fourmile is the sediment that was removed from the YMCA Camp Shady Brook Pond (Kiwanis Lake). During the first 4 months after the fire (about July to October 2002), 5 to $6 \mathrm{ft}$ of organic and inorganic sediment was captured in the pond. The pond was drained and approximately 10,000 yards of sediment was removed in October 2002 (Merv Bennett, President/CEO, YMCA of the Pikes Peak Region, written commun., May 31, 2006, and oral commun., February 10, 2010). An additional 30,000 cubic yards of sediment was excavated from the pond (fig. 38) in March 2005 and represented sediment trapped during the period from November 2002 to March 2005 (Merv Bennett, President/CEO, YMCA of the Pikes Peak Region, written commun., May 31, 2006). The material seemed to have a quasi-bimodal particle-size distribution with sand and gravel deposited in the inlet area and black, organic-rich, fine-grained 

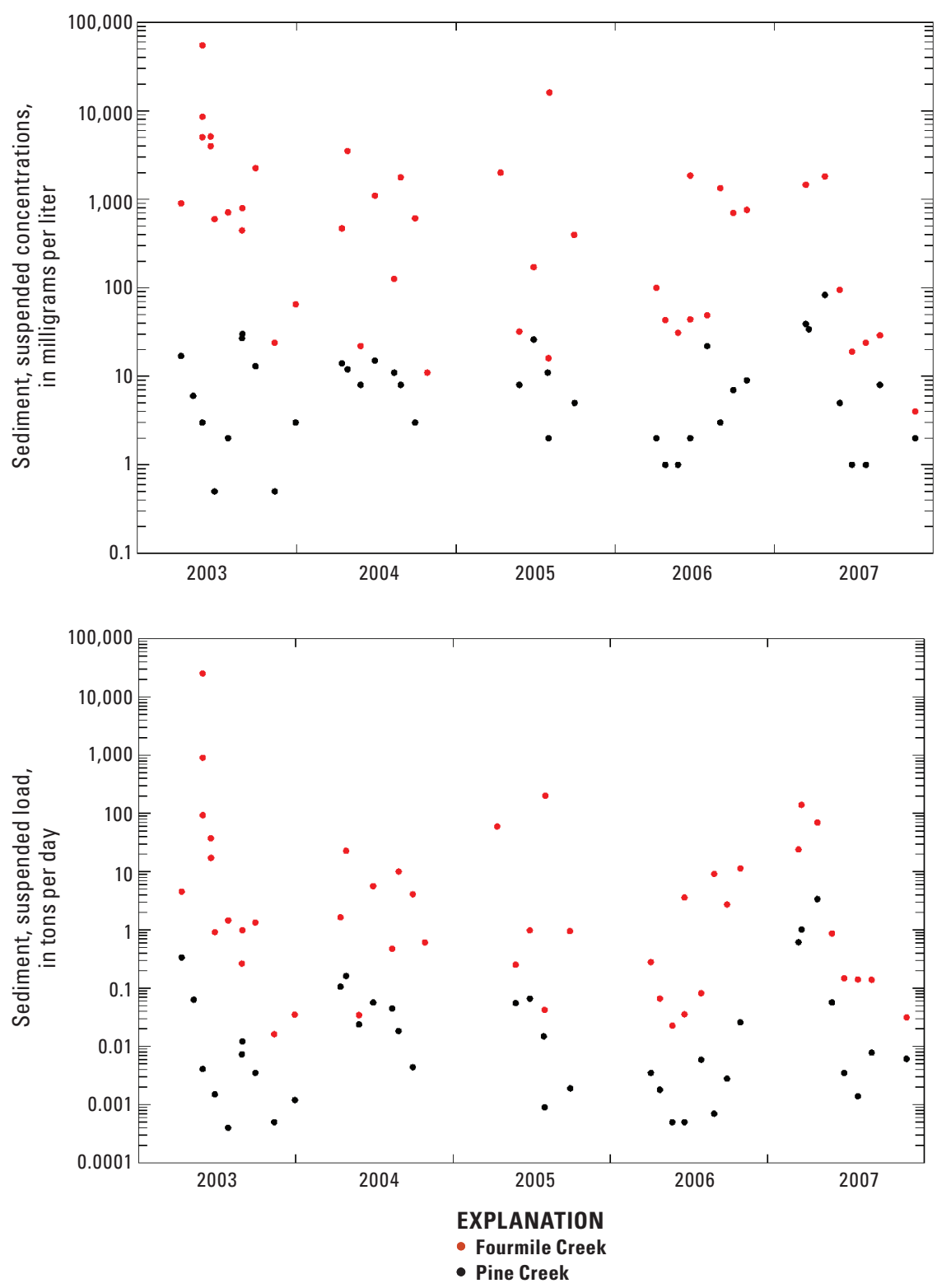

Figure 37. Graphs showing time-series of instantaneous suspended-sediment concentrations and loads at Fourmile and Pine Creeks, 2003 through 2007.

material occurring in the rest of the pond (fig. $35 G$ ). Assuming the dry bulk density averages are about that of coarse sand (1.75 grams per cubic centimeter or 1.47 tons per cubic yard), the 40,000 yards of sediment is about 59,000 tons. Furthermore, assuming that the pond contained sediments mainly from 2002, 2003, and 2004 (inflow was being diverted around pond by the start of snowmelt 2005), the approximate annual yield for Fourmile was about 2,650 tons $/ \mathrm{mi}^{2}$ per year (or 10.2 tons per hectare per year). Considering that fine-grained suspended sediment was transported out of the pond outlet, actual total yields were somewhat larger. This 3-year average annual sediment yield in the Hayman fire area (10.2 tons per hectare) was generally larger than the yields documented for hillslope erosion (median 0.62 tons per hectare) or channel suspended sediment (median 0.66 tons per hectare), and much smaller than most of the documented suspendedsediment yields (median 220 tons per hectare) in the literature for the Plains medium "regional precipitation regime" and the measurement method of capture called channel volume (such as sediments excavated from behind a dam) (Moody and Martin, 2009).

Turbidity is a measure of water clarity, which is affected primarily by the presence of suspended sediment and suspended-organic matter. Increasing turbidity may reduce light penetration needed to sustain growth of periphyton (algae) and may affect the feeding habits of fish (MacDonald and others, 1991). Field turbidity measurements indicated that Fourmile turbidity greatly exceeded Pine turbidity. Turbidity measured 


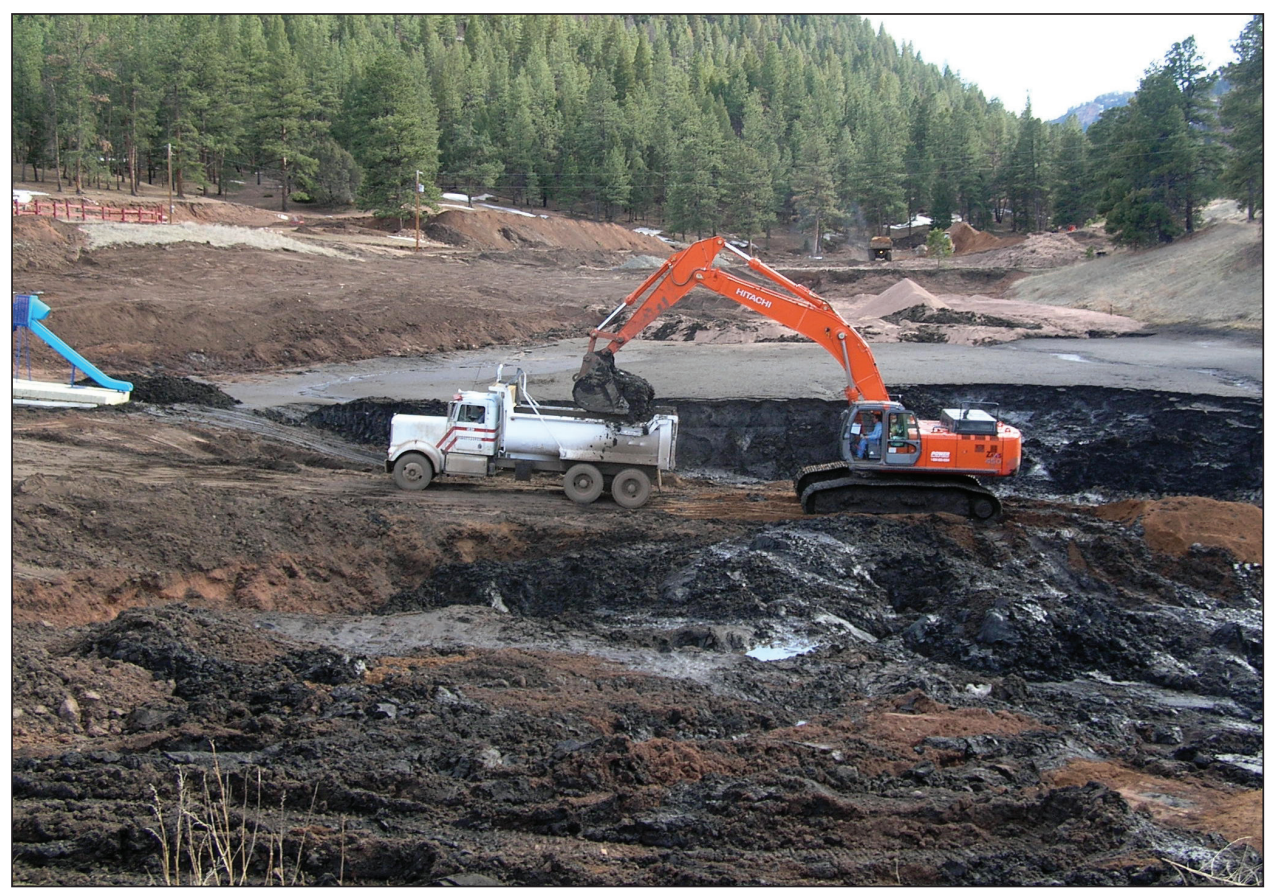

Figure 38. Photographs showing removal of an estimated 30,000 cubic yards (estimated to be about 44,000 tons) postfire sediment accumulated from November 2002 to March 2005 from the YMCA Camp Shady Brook swimming pond (Kiwanis Lake) (Photograph taken by Greg Smith, U.S. Geological Survey, used with permission).

during the collection of water-quality samples ranged from 1.1 to 19,900 NTU at Fourmile (burned site) and from 0.6 to 35 NTU at Pine (unburned site) (appendix 2). Comparison of paired turbidity values at Fourmile and Pine using the Wilcoxon signed-rank test indicated significantly larger turbidity concentrations in Fourmile (p-value <0.10) (table 3).

Turbidity also was measured using a continuous instream water-quality probe at the South Platte Trumbull gaging station (fig. 39). As an indicator of suspended sediment, turbidity is useful for understanding suspended-sediment transport dynamics, and turbidity can sometimes be used as a surrogate for estimating fine suspended-sediment transport. The turbidity was consistently high ( 25 to 100 NTU) during the 2003 snowmelt (March-May) and even higher (50 to 200 NTU) during the months when sediment transport was affected by thunderstorms (end of May through mid-September). The turbidity record (March through September 2003) indicates that daily maximum turbidity was frequently greater than 200 NTU. During rainstorms, some turbidity values exceeded 1,000 NTU (fig. 39), which is the maximum range for the equipment used to measure continuous turbidity in this study. These continuous turbidity data indicate that the South Platte River was consistently transporting material derived from burned tributaries both during snowmelt, thunderstorms, and probably by moving surplus transport-limited sediments from the streambed between storms. Large amounts of water were released from Cheesman Lake in September, increasing turbidity for several days, which was probably a result of scouring accumulated sediment from the streambed (fig. 39).

\section{Hinman Fire Study Area}

Field turbidity measurements indicated that postfire turbidity was larger than prefire turbidity. Median prefire turbidity was 0.64 NTU at Lost Dog and 0.55 NTU at North Fork Elk, and postfire medians were 2.50 NTU and 3.00 NTU, respectively (appendix 2). Comparison of prefire and postfire field turbidity values at Lost Dog and North Fork Elk using the Mann-Whitney rank-sum test also indicated larger turbidity values in postfire samples at both sites (p-value $<0.10$ ) (tables 7 and 8). Flow-weighted turbidity, however, was significantly larger only for Lost Dog (table 7).

Similar to prefire and postfire comparisons for the Hayman fire paired-watershed study, the data indicated that postfire samples contained much larger concentrations of suspended sediment than prefire samples at Lost Dog and at North Fork Elk. The suspended-sediment concentrations in samples ranged from less than 1 to $10 \mathrm{mg} / \mathrm{L}$ in prefire samples at Lost Dog (1999 and 2000) and from 3 to $565 \mathrm{mg} / \mathrm{L}$ in postfire samples (2003) (fig. 40) (appendix 2). Suspendedsediment concentrations ranged from less than 1 to $21 \mathrm{mg} / \mathrm{L}$ in prefire samples at North Fork Elk (1999 and 2000) and from 2 to $305 \mathrm{mg} / \mathrm{L}$ in postfire samples (2003). Suspended-sediment postfire samples tended to be fine grained, which facilitated transport of the sediment. Although no prefire data were available, the median percentage of silt and clay (particles finer than 0.062 millimeter) in postfire samples was 54 percent at Lost Dog and 58 percent at the North Fork Elk. The median prefire load of suspended sediment was 0.060 ton per day at Lost Dog and 0.103 ton per day at North Fork Elk, and the 
median postfire loads were 3.95 tons per day at Lost Dog and 34.4 tons per day at North Fork Elk. Using the Mann-Whitney rank-sum test, comparison of prefire and postfire instantaneous suspended-sediment concentrations and computed loads normalized to drainage area indicated larger values in postfire samples collected from Lost Dog and North Fork Elk (p-value $<0.10$ ) than from the prefire samples (tables 7 and 8).

A plot of the relation between suspended sediment and streamflow at Lost Dog (fig. 33D) shows that concentrations (similar to calcium and nitrite plus nitrate, discussed previously) for the 2003 rising limb (April through mid-June, a period when erosion of burned surfaces was greatest) of the hydrograph were much larger than the prefire 1999-2000, 2003 falling limb, and 2006 sample concentrations, which did not have similar patterns. A return to suspended-sediment concentrations in 2006 (all snowmelt samples) to a level about an order of magnitude lower, supports observations that surface vegetation cover was recovering substantially by 2006 , reducing sources of sediment in the Lost Dog watershed.

\section{Comparison of Hayman and Hinman Fire Study Results}

In general, instantaneous concentrations and area-normalized loads of suspended sediment were not significantly larger (Mann-Whitney p > 0.10) (table 9) in Fourmile than in Lost Dog, despite some differences in the medians and some of the largest concentrations and loads. Therefore, with the limited number of samples (which probably added to the lack of statistical significance), the snowmelt- generated runoff in the Hinman fire area was statistically similar to the rainfallaffected and weathered granitic soils of the Hayman fire area. Large suspended-sediment concentrations and loads probably occurred because of storms in the first months following the Hayman fire in June 2002, which, if sampled, might have changed the median such that Fourmile suspended-sediment concentrations and loads would have been larger than those at Lost Dog. In addition, it was observed that substantial amounts of bed-load sediments were transported in Hayman area streams compared to Hinman area streams. Bedload was not measured with suspended-sediment samples.

\section{Temporal Trends}

Some studies report that postfire suspended-sediment concentrations and loads recover after fire similar to other water-quality constituents, as indicated by downward temporal trends in concentration and yield (Moody and Martin, 2001a; Veenhuis, 2002; Helvey, 1980). In a burned watershed in Arizona, Desilets and others (2007) observed a decrease over time in the suspended-sediment concentration for a given streamflow. This was attributed to a decreased postfire supply of sediment and the removal of finer sediment, resulting in less sediment of the size capable of being transported in the suspended fraction. Martin and Moody (2001) also

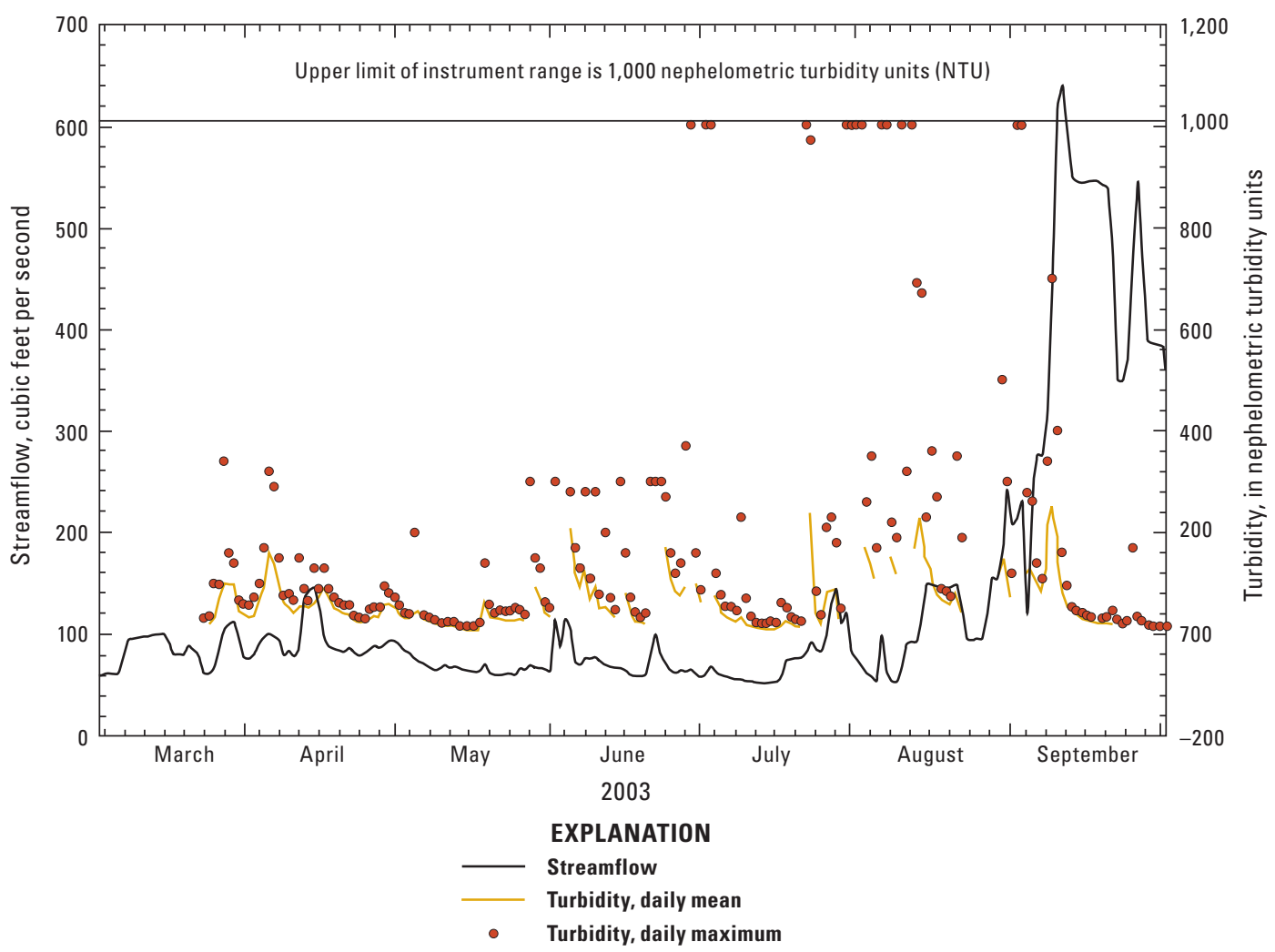

Figure 39. Graph showing daily mean, daily maximum turbidity, and daily mean streamflow at South Platte River below Brush Creek near Trumbull, 2003. 

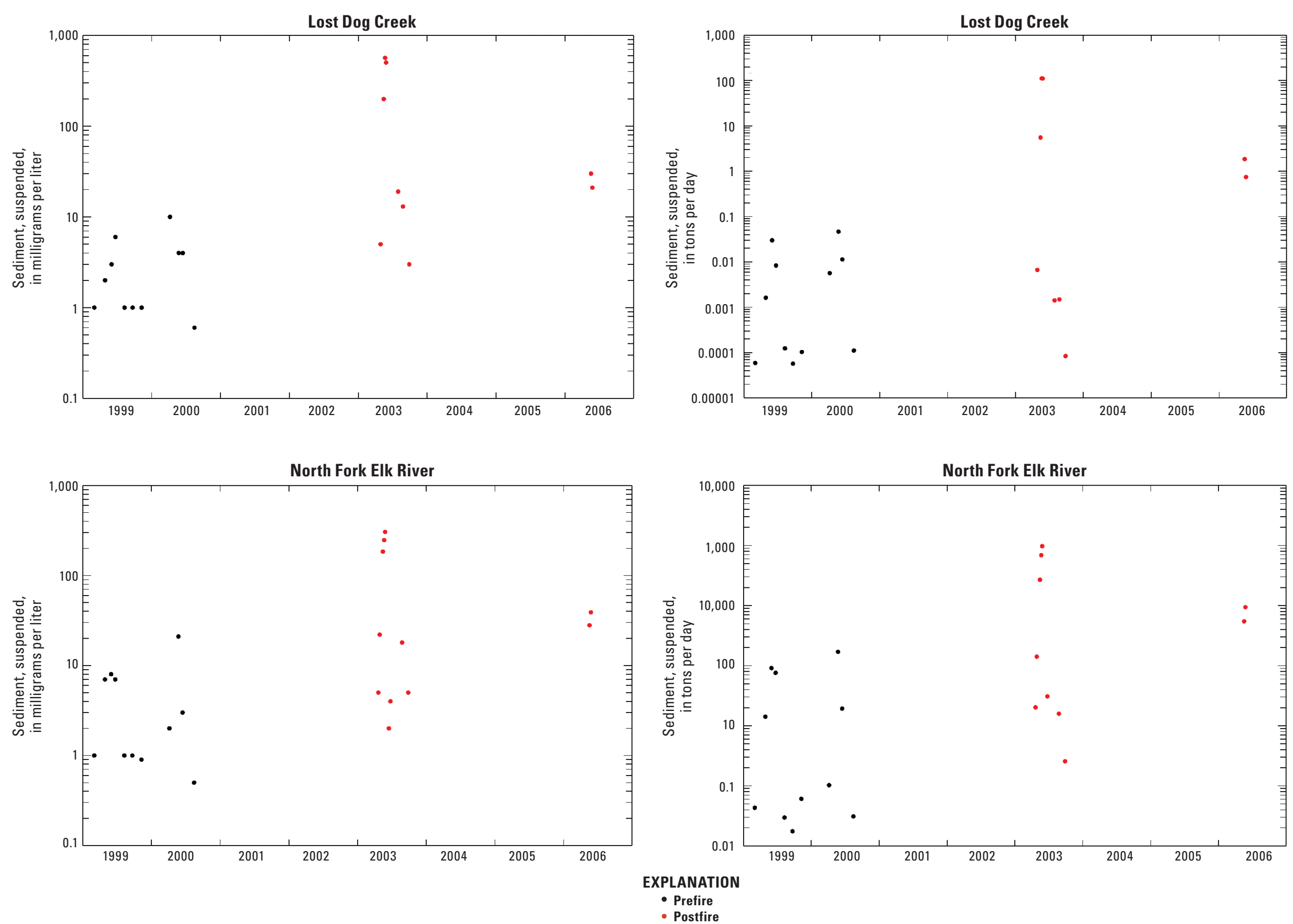

Figure 40. Graphs showing time-series of instantaneous suspended-sediment concentrations and loads at Lost Dog Creek and North Fork Elk River, 1999 through 2006. 
noted this apparent coarsening in hillslope sediments with time in the Spring Creek watershed (fig. 1) burned in the Buffalo Creek fire area, which is near the Hayman fire study area. Other studies attributed downward trends in sediment transport to postfire vegetation recovery (Mayor and others, 2007; Helvey, 1980). Suspended-sediment data were evaluated to determine changes since the Hayman (2003-2007) and Hinman fires (1999 and 2000 prefire data were compared to 2003 postfire data).

Trend testing of suspended-sediment concentrations and loads for 5 years postfire (2003-2007) at Fourmile and Pine (fig. 37) were assessed by using the seasonal Kendall test. When suspended-sediment concentrations (LOWESS-adjusted for streamflow) and load (not adjusted) at Fourmile were trend tested, there were no significant trends in turbidity, but downward trends (percent decrease per year over 5 years) in suspended-sediment concentration (-47.2) and load (-44.5) were statistically significant ( $p$-value $<0.10$; tables 4 and 10), indicating a substantial decrease in suspended-sediment concentration and load during the 5-year period. When suspended-sediment concentrations (LOWESS-adjusted for streamflow) and load (not adjusted) at Pine were trend tested, there were no significant trends in turbidity or suspendedsediment concentration and load (tables 5 and 11).

\section{Loads Analysis}

Methods for the load analysis are described in detail in the "Methods" section. In this study, suspended-sediment load was computed by using concentration data, turbidity, and available daily mean streamflow computed from continuous streamflow records (for the Fourmile burned site) or daily mean streamflow estimated by hydrographic comparison and instantaneous measurements made during water-quality sampling (for the Pine watershed, unburned site) for April through September 2003. Similarly, suspended-sediment loads were computed for Lost Dog and North Fork Elk by using prefire (1999) and postfire (2003) streamflow data estimated by hydrographic comparison and instantaneous measurements made during water-quality sampling. Continuous daily mean turbidity record was used to estimate suspended-sediment load at South Platte Trumbull (station 06701900). The computations used linear regressions (commonly with log transformations of the data) of instantaneous suspendedsediment loads and the instantaneous streamflows or turbidity from each site. Daily suspended-sediment loads were computed by entering daily mean streamflow or turbidity into the regression equation and using the result as the daily mean suspended-sediment load. These loads, summed for a 6-month period (April-September) will hereinafter be referred to as "total seasonal load." Hydrograph comparison and regression techniques may add substantial potential uncertainty to these estimated loads.

\section{Hayman Fire Study Area}

Total seasonal (April-September) suspended-sediment loads at Fourmile and Pine for the first postfire year (2003) indicate that loads (normalized to drainage area) at Fourmile (1,160 tons per square mile; fig. $34 I$; table 12) were almost three orders of magnitude larger than loads at Pine (3.22 tons per square mile). The seasonal total suspended-sediment load at South Platte Trumbull (12,300 tons) was somewhat larger than the load at Fourmile (8,540 tons). However, the suspended-sediment yield, normalized to streamflow volume (tons per acre-foot), was smaller at South Platte Trumbull ( 0.236 tons per acre-ft) than at Fourmile (12.1 tons per acre-ft), indicating higher yields per acre-foot (a streamflowweighted concentration) in the smaller Fourmile watershed.

\section{Hinman Fire Study Area}

Estimated seasonal suspended-sediment loads at Lost Dog and North Fork Elk for prefire (1999) and postfire (2003) conditions indicate that suspended-sediment loads (normalized by drainage area) for postfire conditions (fig. 34I; table 12) were more than two orders of magnitude larger than prefire suspended-sediment loads at Lost Dog, and about one order of magnitude larger than prefire loads in North Fork Elk.

\section{Comparison of Hayman and Hinman Fire Study Results}

1. When total seasonal suspended-sediment loads (normalized to drainage area) were compared among the burned streams evaluated in the Hayman fire and Hinman fire study areas, loads at the Hayman fire (Fourmile) are the largest for suspended sediment $\left(1,160\right.$ tons $\left./ \mathrm{mi}^{2}\right)$ (fig. $34 I$; table 12$)$ compared to the Hinman fire (Lost Dog) area (517 tons $\left./ \mathrm{mi}^{2}\right)$ This 1 -year comparison may indicate that the rainstormdominated and weathered-granitic terrain may be more vulnerable to postfire sediment erosion than the snowmelt-dominated, mixed geology of the Hinman fire area. Among the small watershed unburned study sites (Pine and prefire Lost Dog), prefire Pine had the greatest sediment load (3.22 tons $/ \mathrm{mi}^{2}$ ) (fig. 34I; table 12), indicating that Hayman fire area hillslopes and stream channels may have larger prefire rates of erosion and stream-sediment transport than the postfire Hinman watershed (Lost Dog, 0.331 tons $/ \mathrm{mi}^{2}$ ). Prefire North Fork Elk had the greatest overall unburned sediment yield of 17.2 tons $/ \mathrm{mi}^{2}$ (table 12); however, the North Fork Elk is a much larger watershed and stream, which may account for the larger unburned sediment yield. 


\section{Potential Effects and Consequences to Postfire Water Quality}

Wildfire affects watersheds in ways that can be devastating not only to areas near the fire but also to areas that rely on water supplies in burned areas. Among the post-fire issues to be discussed in the following sections are streams, lakes and reservoirs, drinking-water treatment, and waterquality standards and aquatic life.

\section{Streams}

The potential postfire effects on streams receiving postfire runoff include degradation of water quality, aggradation or degradation of stream channels, excess sediment transport, eutrophication of stream reaches, increased chemical or biological oxygen demand, the mobilization and transport of trace elements, and potential adverse effects to human and aquatic life.

From the analysis presented in this report, it is clear that streamflow and transport of water-quality constituents are substantially higher in the immediate postburn condition (the first year after the fire) and continue to be higher for years thereafter. Concentrations of almost every water-quality constituent were higher in streams receiving postfire runoff than in reference streams that were not affected by fire. Loads in fire-affected streams were up to orders of magnitude larger than in reference streams that were not affected by fire.

The high postfire streamflow documented in this study can destabilize channels and cause aggradation and degradation and (or) erosion of streambed and streambank material. Once fire disrupts hydraulic and sediment-transport equilibrium, channel bed and banks may take long periods to stabilize, especially in the watersheds underlain by weathered Pikes Peak Granite such as in the Hayman fire study area. Fire-affected channels recently (2011) have caused elevated concentrations of sediment and water-quality constituents to streams and reservoirs within, and downstream from, the Hayman fire area (oral commun. Robert Jarrett, 2010, U.S. Geological Survey). Some stream reaches in the fireaffected areas may not be able to transport the increased influx of sediment and debris, which may cause aggradation of material in the streambed and may change channel morphology if choked with excess sediment (fig. 41) (Moody, 2001; Benda and others, 2003). Instability in streambeds or streambanks can disrupt irrigation structures or diversions or can cause damage to streamside dwellings and property. High concentrations of transported suspended sediment can disrupt algal primary productivity in streams by inhibiting light needed for photosynthesis (Parkhill and Gulliver, 2002). High streamflow and sediment transport may scour rock surfaces and disturb growth of algae and bacteria that provide food for macroinvertebrates (Biggs and others, 1999). Macroinvertebrate populations showed lower densities and biomass in burned watersheds of the Hayman fire for at least

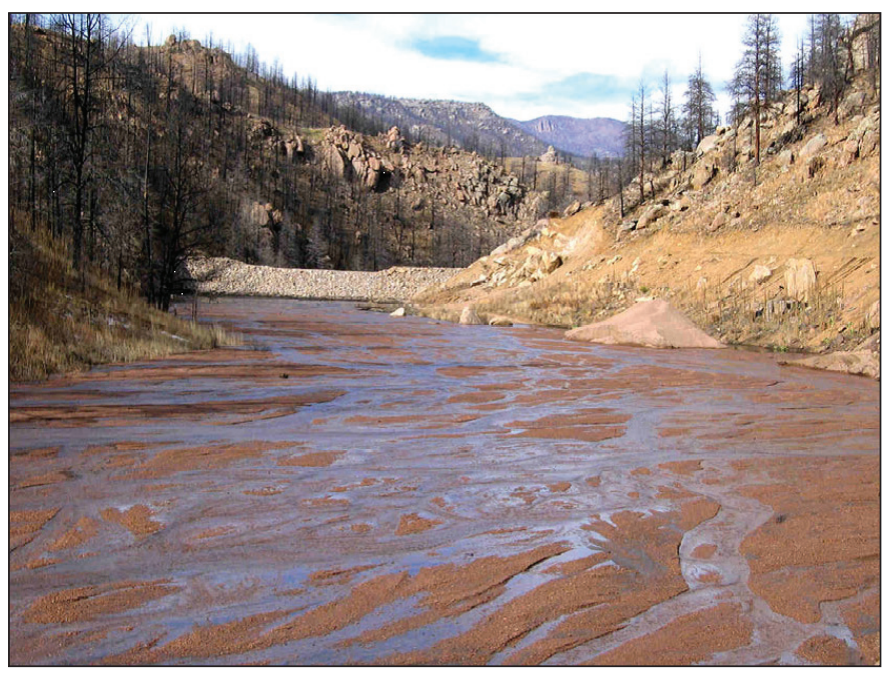

Figure 41. Photograph showing silted-in debris dam (42 feet high) constructed by Denver Water on Turkey Creek (a tributary that enters Cheesman Lake) to retain sediment transported after the Hayman fire (Photograph used with permission from the Colorado Office of the State Engineer, 2004).

2 years postfire, as described in Hall and Lombardozzi (2008). Sediment also can degrade spawning habitat by covering or smothering gravels crucial to trout-spawning success and filling pools or covering riffles that are fish habitat (Reeves and others, 1995). Jeff Spohn, a Colorado Division of Wildlife fisheries biologist, has documented that trout populations in a reach of the South Platte River below Deckers went from 4,800 trout over 6 in. in length per mile (prior to most of the postfire runoff), to about 1,100 per mile in 2004 (after much of the postfire runoff) (Licis, 2009). Population estimates in 2008 showed some recovery with about 1,800 trout per mile in the same reach (Licis, 2009). Postfire sediment influx also may replenish spawning gravels and woody debris and result in greater habitat complexity in some stream systems over the long term (Reeves and others, 1995).

Postfire concentrations and loads of nutrients, trace elements, organic carbon, and suspended sediment were up to orders of magnitude larger than in reference streams that were not affected by fire, which may degrade water quality farther downstream in streams, lakes, and reservoirs. The higher concentrations of nutrients in fire-affected streams, as documented in this report, especially those that are generally considered to be bioavailable in the short-term (ammonia, nitrate, orthophosphorus), can cause excess aquatic growth of periphyton (Allan, 1995) or even rooted macrophytes. The increased algal productivity may disrupt the food web by changing functional feeding conditions for macroinvertebrates and fish (Spencer and others, 2003; Allen, 1995) or cause problems such as clogging water intakes or filters at watertreatment plants (Satterfield, 2006b).

In 2003, large accumulations of periphyton and macrophytes observed in Fourmile and the South Platte River downstream from Deckers (fig. 28) seem to indicate that 
postfire nutrients were available to stimulate growth. This effect, however, was not observed in the following 4 years. This is the same pattern of postfire stream periphyton growth and patterns observed in streams by Spencer and others (2003) after the 1988 Red Bench fire in Glacier National Park. Data and observations in this study support the short-lived nature of early eutrophic responses in receiving waters.

The high postfire organic carbon concentrations and loads in this study may react with dissolved oxygen in streams and reduce oxygen concentrations (chemical and biological oxygen demand) needed to sustain fish and other aquatic life. Dissolved oxygen in streams was not measured in this study, but other studies have documented low oxygen concentrations during postfire runoff events, and fish kills have occurred in streams after wildfire due to changes in water temperature, water chemistry, and habitat (Gresswell, 1999; Dunham and others, 2003; Earl and Blinn, 2003). Fish kills were observed immediately following the Hayman fire and the first runoff events in some area streams and in Cheesman Lake (Kershner and others, 2003).

Of the trace elements measured in this study, mercury is one of the most problematic. Mercury was mostly analyzed in the total recoverable form in this study, and only a few samples were analyzed for dissolved mercury, which was found in low concentrations. Particulate-related mercury may be less bioavailable than other forms of mercury, especially when associated with organic matter (Zhong and Wang, 2006). Methylmercury, a toxic chemical form, however, can be produced by biological processes and conditions that include low oxygen and abundant organic carbon and sulfate (Gilmour and others, 1992; Driscoll and others, 2007), which can occur after wildfire. Skyllberg and others (2009) attribute elevated concentrations of methylmercury in streams after logging to degradation of logging residue and soil organic matter that acts as electron donors for methylating bacteria. Similarly, increases in stream transport of burned and unburned biomass are common after fire ((Minshall and others, 1997) and may potentially result in increases in methylmercury. Methylmercury, which is a potent neurotoxin, could bioaccumulate in higher trophic levels such as predatory fish, which may pose a threat to human health (Driscoll and others, 2007). Kelly and others (2006) attributed increased mercury concentrations in fish to the effects of postfire-related increased productivity, food web alterations, and mercury inputs.

\section{Lakes and Reservoirs}

The relative fertility and productivity of a lake or reservoir can be evaluated by assessing the trophic status. Oligotrophic (nutrient-poor) lakes and reservoirs exhibit high transparency, low organic-matter content, relatively high concentrations of dissolved oxygen, low nutrient concentrations, and small algal biomass (Woods, 1992). Eutrophic (nutrientrich) lakes and reservoirs have the opposite characteristics. The major cause of increasing eutrophication is increased inputs and loads of nutrients (nitrogen and phosphorus) (Cole, 1994). Because nutrients are commonly cycled within the lake biogeochemical system, loads of nutrients may have effects for long periods. Therefore, despite the widely held belief that water quality recovers rapidly following wildfire, the large contributions of nitrogen and phosphorus in the first few postfire years may leave a legacy of excess fertility in reservoirs. Thus, the potential effects of large wildfires and post-wildfire nutrient loads on reservoirs may not be anticipated because many forests have not burned since the construction of many reservoirs, and water quality in reservoirs may take longer than water quality in streams to recover to prefire conditions. For example, the presence of excess nutrients (including phosphorus) in postfire runoff, in the right bioavailable forms and concentrations, can cause phytoplankton to multiply to levels that impair water clarity and disrupt the beneficial use of water for drinking-water treatment (fig. 42). Additional problems are described in the "Drinking-Water Treatment" section. The dissolved oxygen profiles for July and August (2002-2004) in Vallecito Reservoir post-Missionary Ridge Fire (burned in 2002) indicated increased hypolimnetic hypoxia compared to prefire (1999-2001) profiles (Wright, 2005). In the bottom $20 \mathrm{ft}$ of the reservoir, dissolved-oxygen concentrations decreased from about $4 \mathrm{mg} / \mathrm{L}$ to about $2 \mathrm{mg} / \mathrm{L}$ with some

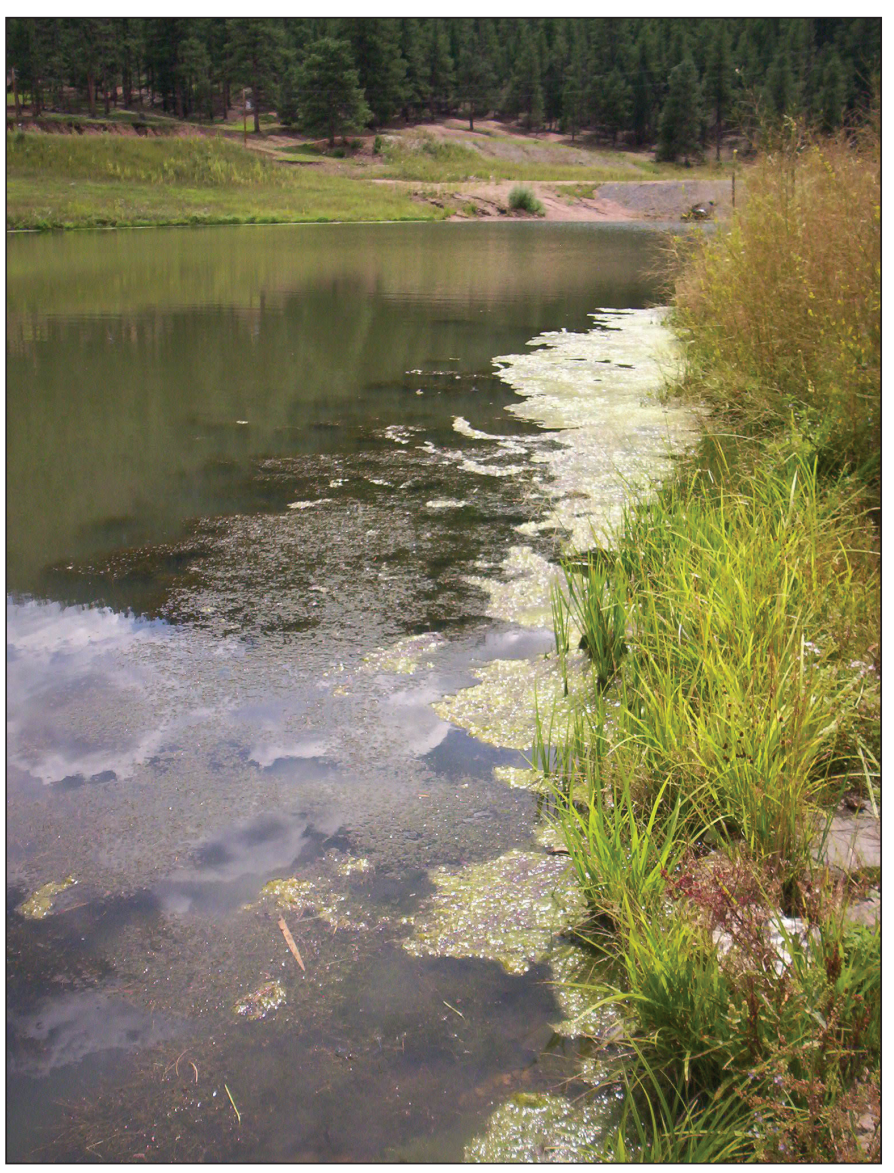

Figure 42. Photograph showing postfire algae growth in Kiwanis Lake at YMCA Camp Shady Brook. 
bottom measurements less than $1 \mathrm{mg} / \mathrm{L}$. A fish kill in Vallecito reservoir in August 2003 was attributed to low dissolved oxygen concentrations by Colorado Division of Wildlife biologists (Rodebaugh, 2005). In addition, increased nutrient loading from runoff after fires also can change food web interactions by increasing algal productivity and thereby increasing zooplankton populations and predation at higher trophic levels. This restructuring of the food web was implicated in higher mercury levels in predatory fish in Moab Lake after wildfire in Jasper National Park, Alberta (Kelly and others, 2006).

In this study, the total estimated 2003 seasonal load (April-September 2003) of phosphorus at South Platte Trumbull was almost 23,000 pounds (table 12). This load would have exceeded the allowable phosphorus load of 17,930 pounds (includes all sources upstream from Strontia Springs Reservoir outlet) (Colorado Department of Public Health and Environment, 2009) for Chatfield Lake, located downstream near Denver, Colorado. It is likely that Strontia Springs Reservoir, which is immediately upstream from Chatfield Lake and an important raw drinking-water intake point for the Denver metropolitan area, retained much of that load. Phosphorus retention probably protected Chatfield Lake from much of the particulate phosphorus fraction, but the possibility exists for increased internal phosphorus loading and release downstream, raising concerns for Denver water providers that utilize Strontia Springs Reservoir. Additional problems are described in the "Drinking-Water Treatment" section.

Increased biomass productivity produces additional organic carbon, some of which is oxidized when phytoplankton die and settle into the hypolimnion, which causes oxygen demand to increase in the part of the water column that does not mix during summer (Garn and others, 2003; Horne and Goldman, 1994). This process along with the large amounts of organic carbon in postfire runoff can cause oxygen concentrations in lakes and reservoirs to become low enough to effect aquatic life and increase redox processes that may cause dissolved forms of nitrogen, phosphorus, iron, and manganese to be released from bed sediments into the water column (Horne and Goldman, 1994). This internal loading of nutrients in lakes and reservoirs may contribute to additional phytoplankton productivity if the bioavailable forms of nitrogen and phosphorus reach the epilimnion or euphotic zone of a water body and is the limiting nutrient for biomass productivity in the water column at that time (Horne and Goldman, 1994). Nutrients from internal loading in the hypolimnion are commonly mixed into zones of potential algal growth in the water column of dimictic water bodies at spring and fall overturn (Horne and Goldman, 1994).

Large postfire loads of suspended sediment and bedload sediment transported to lakes or reservoirs by streams may cause problems in certain water bodies. This sediment may be composed of organic and inorganic solids, and if grain sizes are small, these sediments may remain suspended in the receiving water body for long periods of time (fig. 43). Loss of clarity can reduce the amount of sunlight that reaches the bottom in shallow areas, causing periphyton and macrophytic growth to be suppressed or die-offs that cause temporary high oxygen demand (fig. 43). Suspended sediment in reservoirs also may cause infrastructure damage by increased abrasion of hydraulic structures or burial of intakes. Large amounts of settled sediment can cause the loss of storage capacity in a reservoir, which may be of minor significance in a large-capacity reservoir or of major concern in a small impoundment. Denver Water has estimated that at least one million tons of firerelated debris will need to be dredged from Strontia Springs Reservoir at an anticipated cost of more than $\$ 20$ million to restore the utility of one of its primary drinking-water diversion reservoirs (Meyer, 2006). The accumulation of sediment at inflows can cause water to become shallow, affecting access by boats, or such accumulation may create shallow conditions favorable for the growth of nuisance macrophytes. Influx of large floating debris (including logs) can be a hazard for boating or reservoir infrastructure (fig. 44).

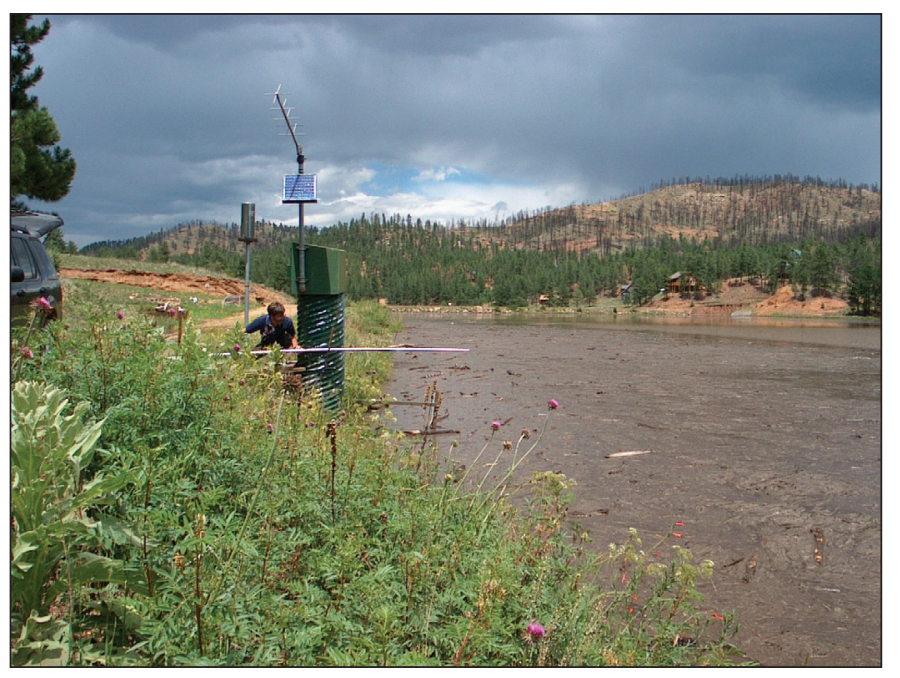

Figure 43. Photograph showing postfire debris and suspended sediment from July 7, 2006, flood in West Creek Lake at West Creek, Colorado.

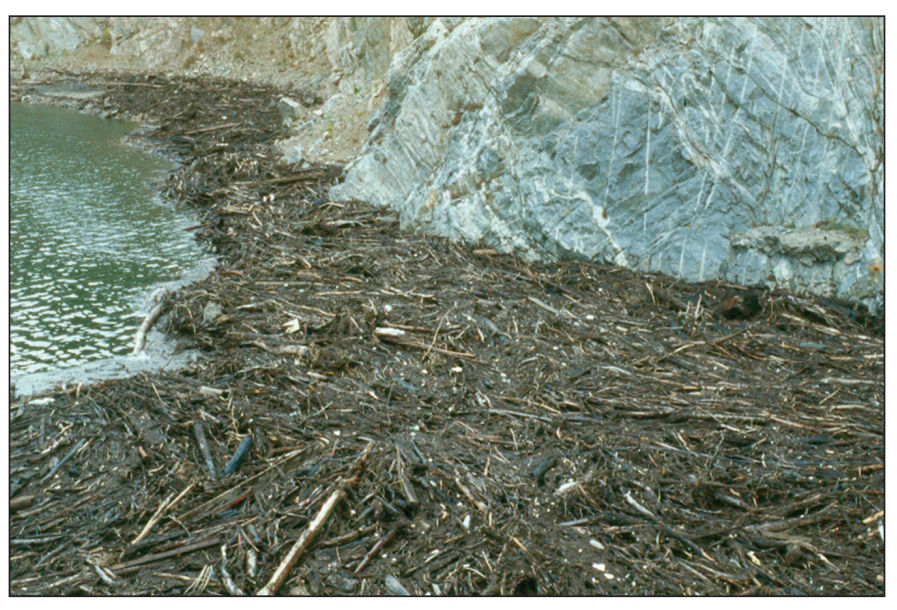

Figure 44. Photograph showing debris in Strontia Springs Reservoir from postfire flood after the Buffalo Creek fire (Photograph by John Moody, U.S. Geological Survey). 


\section{Drinking-Water Treatment}

Drinking water is commonly drawn from surface-water supplies in many areas of the Western United States because of the generally high quality of streamwater sources in sparsely developed watersheds. Many of these areas are also forested and at risk of wildfire. Postfire runoff poses many challenges for the treatment of drinking water, especially for water providers that are accustomed to relatively minimal requirements. Although large water-treatment facilities can engineer processes to remove postfire contaminants, cost increases are passed through to customers (Dissmeyer, 2000).

Several effects of postfire runoff described in this study can interfere with the treatment of drinking water. Postfire runoff can damage infrastructure such as reservoirs, intakes, diversion structures, and conveyances, which can interfere with diversion and transport of water to the treatment facility or reduce the operational efficiency of the treatment system (Meixner and Wohlgemuth, 2004). The potential abundance of fine sediment, organic matter, manganese, and taste and odor compounds may decrease the efficiency of treatment processes and the quality of finished drinking water. Fine suspended sediment (commonly indicated by turbidity measurements) can make drinking-water disinfection more difficult and facilitates the growth of bacteria in the distribution system (Landsberg and Tiedemann, 2000). Removal of excess suspended sediment (including particulate organics) may require additional coagulation chemicals and settling time and may slow plant production (Satterfield, 2006b). Dissolved organic material is one of the precursors of THMs (regulated carcinogens) that result from the chlorination of organic compounds (Volk and others, 2005). In addition, DOC encourages growth of microorganisms that may produce taste and odor compounds (Volk and others, 2005; Gill, 2004). Pretreatment with potassium permanganate can oxidize organic material prior to the addition of chlorine, thus reducing potential for THM formation (Carus Chemical Company, 2000). Organic compounds that cause taste and odor in drinking water also may be removed or decreased by oxidation early in the treatment process (Satterfield, 2006a). Manganese is released from biomass during pyrolysis and is eroded along with soil material also containing manganese (Parra and others, 1996). Manganese in dissolved form can be oxidized and precipitates under some natural stream conditions, but the reaction time is slow (National Drinking Water Clearinghouse, 1998). The addition of potassium permanganate or additional oxidation by ozone can remove manganese from raw drinking water (Carus Chemical Company, 2000). Although enhanced treatment can be successful in mitigating postfire runoff problems, increased cost may result from increased use of chemicals and waste disposal (Dissemeyer, 2000; Satterfield, 1998). The rapidly changing quality of postfire runoff from storms necessitates the adjustment of the treatment process to changes in raw water quality (Satterfield, 1998) that complicates process optimization (Cottingham, 2005).

\section{Water-Quality Standards and Aquatic Life}

Study results were compared to stream standards established by the Water Quality Control Commission of the Colorado Department of Public Health and Environment (CDPHE). The stream standards (hereinafter referred to as "standards") are described in Regulations 31, 33, and 38 (Colorado Department of Public Health and Environment, 2008a, 2008b, 2008c).

The standards include "Fixed" and "Table Value" Standards. The Fixed Standards set specific levels, or in some cases ranges, whereas the Table Value Standards utilize equations that define standards on the basis of hardness values. In this report, the hardness values associated with each individual sample were used to compute Table Value Standards. Table Value Standards for ammonia defined in Regulation 31 were used in this report. In the vast majority of cases, standards associated with Cold Water Class 1 classifications were used. However, Cold Water classifications for Cold Water trout were used for the acute cadmium standard, and Domestic Water Supply standards were used for chloride, sulfate, and nitrite plus nitrate. In many cases, the regulations define both acute standards, a value or concentration not to be exceeded by either a single sample or by the average of all samples collected during a 1-day period; and chronic standards, a value or concentration not to be exceeded by a set of representative samples collected over a representative period.

The comparisons of investigative results to stream standards are summarized in table 13 , which includes specific results that represent exceedances of standards. Table 13 includes descriptions of the number of investigative results available and how many of those results were uncensored (not qualified as estimated). For example, for the chronic Table Values Standard (acute and chronic) for dissolved copper at Lost Dog, 13 of the 16 sample concentrations were uncensored (table 13); in this case, 1 sample concentration exceeded the computed standard (unique to the hardness value for that sample).

Based on Colorado water-quality standards, postfire water quality (2003-2007) in Fourmile, which was affected by the Hayman fire, and Lost Dog and North Fork Elk, which were affected by the Hinman fire, were generally acceptable for specified use classifications of recreation, water supply, agriculture, and aquatic life. In general, concentrations of dissolved solids, nutrients, trace elements, and suspended sediment were low in streams in the unburned watersheds, and concentrations of dissolved solids, nutrients, trace elements, and suspended sediment in streams in burned watersheds were large. However, many of the water-quality effects that contribute to degradation of habitat and complicate water treatment are not regulated by the State of Colorado.

Some concentrations for individual samples occasionally exceeded concentrations computed from the Colorado streamwater-quality standards (table 13); however, more sampling would be required to meet the detailed definitions of the chronic standards. Because many of the regulated constituents likely to be of concern in natural streams are dissolved trace elements, the relatively neutral $\mathrm{pH}$ in postfire runoff maintains 
[--, no data or no standard; mg/L, milligrams per liter; $\mu \mathrm{g} / \mathrm{L}$, micrograms per liter; <, less than; $\mathrm{mg} / \mathrm{L}$, milligrams per liter; $\mu \mathrm{g} / \mathrm{L}$, micrograms per liter; TVS, table value standards equation; standards from Colorado Department of Public Health and Environment, Water Quality Control Commission (2008); only data greater than or equal to the reporting limit were compared to standards; nitrite plus nitrate concentration is used instead of nitrate for comparison to standard as nitrite concentrations are generally negligible; uncensored samples without hardness for trace elements or water temperature and $\mathrm{pH}$ for ammonia samples were not included in the exceedance computations]

\begin{tabular}{|c|c|c|c|c|c|c|c|c|}
\hline \multirow{2}{*}{$\begin{array}{l}\text { Water-quality constituent } \\
\text { or measurement }\end{array}$} & \multirow{2}{*}{$\begin{array}{l}\text { Total number } \\
\text { of samples }\end{array}$} & \multirow{2}{*}{$\begin{array}{c}\text { Total number } \\
\text { of uncensored } \\
\text { samples }\end{array}$} & \multirow{2}{*}{$\begin{array}{l}\text { Type of } \\
\text { standard }\end{array}$} & \multicolumn{2}{|c|}{ Range of concentration } & \multicolumn{2}{|c|}{ Standards } & \multirow{2}{*}{$\begin{array}{c}\text { Number of uncensored } \\
\text { sample exceedances }\end{array}$} \\
\hline & & & & Minimum & Maximum & Chronic & Acute & \\
\hline \multicolumn{9}{|c|}{ Fourmile Creek } \\
\hline $\mathrm{pH}$, lab, standard units & 45 & 45 & Fixed & 6.9 & 8.1 & -- & 6.5 to 9.0 & 0 \\
\hline Chloride, dissolved, mg/L & 39 & 39 & Fixed & 1.8 & 3.5 & -- & 250 & 0 \\
\hline Sulfate, dissolved, $\mathrm{mg} / \mathrm{L}$ & 41 & 41 & Fixed & 7.1 & 24.3 & -- & 250 & 0 \\
\hline \multirow[t]{2}{*}{ Ammonia, dissolved, $\mathrm{mg} / \mathrm{L}$} & 43 & 21 & TVS acute & 0.005 & 0.494 & -- & 5.6 to 22 & 0 \\
\hline & 43 & 21 & TVS chronic & 0.005 & 0.494 & 11 to 62 & - & 0 \\
\hline Nitrate, dissolved, mg/L & 43 & 43 & Fixed & 0.085 & 4.3 & -- & 10 & 0 \\
\hline Arsenic, total recoverable, $\mu \mathrm{g} / \mathrm{L}$ & 40 & 30 & Fixed & 0.29 & 75 & -- & 50 & 1 \\
\hline \multirow[t]{2}{*}{ Cadmium, dissolved, $\mu \mathrm{g} / \mathrm{L}$} & 41 & 15 & TVS acute, trout & 0.02 & 0.115 & -- & 0.9 to 3.5 & 0 \\
\hline & 41 & 15 & TVS chronic & 0.02 & 0.115 & 2.1 to 5.3 & -- & 0 \\
\hline \multirow[t]{2}{*}{ Copper, dissolved, $\mu \mathrm{g} / \mathrm{L}$} & 40 & 39 & TVS acute & 0.20 & 1.86 & -- & 6.4 to 21 & 0 \\
\hline & 40 & 39 & TVS chronic & 0.20 & 1.86 & 5.4 to 16 & -- & 0 \\
\hline Iron, dissolved, $\mu \mathrm{g} / \mathrm{L}$ & 41 & 40 & Fixed & 5 & 106 & 300 & -- & 0 \\
\hline Iron, total recoverable, $\mu \mathrm{g} / \mathrm{L}$ & 41 & 41 & Fixed chronic & 192 & 542,000 & 1,000 & -- & 33 \\
\hline \multirow[t]{2}{*}{ Lead, dissolved, $\mu \mathrm{g} / \mathrm{L}$} & 41 & 17 & Fixed acute & 0.04 & 0.3 & -- & 16 to 66 & 0 \\
\hline & 41 & 17 & Fixed chronic & 0.04 & 0.3 & 0.3 to 1.1 & -- & 0 \\
\hline \multirow[t]{3}{*}{ Manganese, dissolved, $\mu \mathrm{g} / \mathrm{L}$} & 41 & 41 & TVS acute & 0.1 & 414 & -- & 30 to 46 & 9 \\
\hline & 41 & 41 & TVS chronic & 0.1 & 414 & 24 to 37 & -- & 9 \\
\hline & 41 & 41 & Fixed & 0.1 & 414 & 50 & -- & 8 \\
\hline Mercury, total recoverable, $\mu \mathrm{g} / \mathrm{L}$ & 41 & 22 & Fixed & 0.001 & 0.381 & 0.01 & -- & 18 \\
\hline \multirow[t]{2}{*}{ Zinc, dissolved, $\mu \mathrm{g} / \mathrm{L}$} & 40 & 34 & TVS acute & 0.05 & 4.4 & -- & 188 to 773 & 0 \\
\hline & 40 & 34 & TVS chronic & 0.05 & 4.4 & 51 to 151 & -- & 0 \\
\hline \multicolumn{9}{|c|}{ Pine Creek } \\
\hline $\mathrm{pH}$, lab, standard units & 38 & 38 & Fixed & 7.3 & 8.3 & -- & 6.5 to 9.0 & 0 \\
\hline Chloride, dissolved, mg/L & 29 & 29 & Fixed & 0.9 & 14.9 & -- & 250 & 0 \\
\hline Sulfate, dissolved, $\mathrm{mg} / \mathrm{L}$ & 36 & 36 & Fixed & 6.5 & 12.5 & -- & 250 & 0 \\
\hline \multirow[t]{2}{*}{ Ammonia, dissolved, $\mathrm{mg} / \mathrm{L}$} & 38 & 9 & TVS acute & 0.005 & 0.113 & -- & 3.8 to 13 & 0 \\
\hline & 38 & 9 & TVS chronic & 0.005 & 0.113 & 10 to 38 & -- & 0 \\
\hline Nitrate, dissolved, mg/L & 38 & 37 & Fixed & 0.015 & 0.703 & -- & 10 & 0 \\
\hline Arsenic, total recoverable, $\mu \mathrm{g} / \mathrm{L}$ & 36 & 16 & Fixed & 0.09 & 2.0 & -- & 50 & 0 \\
\hline \multirow[t]{2}{*}{ Cadmium, dissolved, $\mu \mathrm{g} / \mathrm{L}$} & 36 & 3 & TVS acute, trout & 0.02 & 0.04 & -- & 0.9 to 1.3 & 0 \\
\hline & 36 & 3 & TVS chronic & 0.02 & 0.04 & 2.2 to 2.8 & -- & 0 \\
\hline \multirow[t]{2}{*}{ Copper, dissolved, $\mu \mathrm{g} / \mathrm{L}$} & 35 & 34 & TVS acute & 0.2 & 1.1 & -- & 4.6 to 13.5 & 0 \\
\hline & 35 & 34 & TVS chronic & 0.2 & 1.1 & 4.0 to 10.6 & -- & 0 \\
\hline Iron, dissolved, $\mu \mathrm{g} / \mathrm{L}$ & 36 & 35 & Fixed & 5 & 116 & 300 & -- & 0 \\
\hline Iron, total recoverable, $\mu \mathrm{g} / \mathrm{L}$ & 36 & 36 & Fixed chronic & 23 & 3,050 & 1,000 & -- & 4 \\
\hline \multirow[t]{2}{*}{ Lead, dissolved, $\mu \mathrm{g} / \mathrm{L}$} & 36 & 8 & Fixed acute & 0.04 & 0.17 & -- & 13 to 39 & 0 \\
\hline & 36 & 8 & Fixed chronic & 0.04 & 0.17 & 0.21 to 0.62 & -- & 0 \\
\hline
\end{tabular}


Table 13. Water-quality standards and exceedances of Colorado stream standards for sampling sites in this study.-Continued

[--, no data or no standard; mg/L, milligrams per liter; $\mu \mathrm{g} / \mathrm{L}$, micrograms per liter; $<$, less than; $\mathrm{mg} / \mathrm{L}$, milligrams per liter; $\mu \mathrm{g} / \mathrm{L}$, micrograms per liter; TVS, table value standards equation; standards from Colorado Department of Public Health and Environment, Water Quality Control Commission (2008); only data greater than or equal to the reporting limit were compared to standards; nitrite plus nitrate concentration is used instead of nitrate for comparison to standard as nitrite concentrations are generally negligible; uncensored samples without hardness for trace elements or water temperature and pH for ammonia samples were not included in the exceedance computations]

\begin{tabular}{|c|c|c|c|c|c|c|c|c|}
\hline \multirow{2}{*}{$\begin{array}{l}\text { Water-quality constituent } \\
\text { or measurement }\end{array}$} & \multirow{2}{*}{$\begin{array}{l}\text { Total number } \\
\text { of samples }\end{array}$} & \multirow{2}{*}{$\begin{array}{c}\text { Total number } \\
\text { of uncensored } \\
\text { samples }\end{array}$} & \multirow{2}{*}{$\begin{array}{l}\text { Type of } \\
\text { standard }\end{array}$} & \multicolumn{2}{|c|}{ Range of concentration } & \multicolumn{2}{|c|}{ Standards } & \multirow{2}{*}{$\begin{array}{l}\text { Number of uncensored } \\
\text { sample exceedances }\end{array}$} \\
\hline & & & & Minimum & Maximum & Chronic & Acute & \\
\hline \multicolumn{9}{|c|}{ Pine Creek-Continued } \\
\hline \multirow[t]{3}{*}{ Manganese, dissolved, $\mu \mathrm{g} / \mathrm{L}$} & 36 & 36 & TVS acute & 0.1 & 42 & -- & 26 to 39 & 1 \\
\hline & 36 & 36 & TVS chronic & 0.1 & 42 & 22 to 32 & -- & 2 \\
\hline & 36 & 36 & Fixed & 0.1 & 42 & 50 & -- & 0 \\
\hline Mercury, total recoverable, $\mu \mathrm{g} / \mathrm{L}$ & 36 & 5 & Fixed & 0.002 & 0.020 & 0.01 & -- & 1 \\
\hline \multirow[t]{4}{*}{ Zinc, dissolved, $\mu \mathrm{g} / \mathrm{L}$} & 35 & 34 & TVS acute & 0.5 & 2.7 & & & \\
\hline & & -- & 128 to 450 & 0 & & & & \\
\hline & 35 & 34 & TVS chronic & 0.5 & 2.7 & & & \\
\hline & & 37 to 100 & -- & 0 & & & & \\
\hline \multicolumn{9}{|c|}{ South Platte River Trumbull } \\
\hline $\mathrm{pH}$, lab, standard units & 15 & 15 & Fixed & 7.3 & 8.2 & -- & 6.5 to 9.0 & 0 \\
\hline Chloride, dissolved, mg/L & 5 & 5 & Fixed & 20 & 25 & -- & 250 & 0 \\
\hline Sulfate, dissolved, $\mathrm{mg} / \mathrm{L}$ & 12 & 12 & Fixed & 20 & 34 & -- & 250 & 0 \\
\hline \multirow{2}{*}{ Ammonia, dissolved, $\mathrm{mg} / \mathrm{L}$} & 14 & 4 & TVS acute & 0.002 & 0.021 & -- & 3.8 to 17.5 & 0 \\
\hline & 14 & 4 & TVS chronic & 0.002 & 0.021 & 9.8 to 49.6 & -- & 0 \\
\hline Nitrate, dissolved, mg/L & 14 & 14 & Fixed & 0.2 & 0.7 & -- & 10 & 0 \\
\hline Arsenic, total recoverable, $\mu \mathrm{g} / \mathrm{L}$ & 13 & 9 & Fixed & 0.6 & 54 & -- & 50 & 1 \\
\hline \multirow[t]{2}{*}{ Cadmium, dissolved, $\mu \mathrm{g} / \mathrm{L}$} & 12 & 2 & TVS acute & 0.02 & 0.04 & -- & 2.4 to 2.6 & 0 \\
\hline & 12 & 2 & TVS chronic & 0.02 & 0.04 & 4.1 to 4.4 & -- & 0 \\
\hline \multirow[t]{2}{*}{ Copper, dissolved, $\mu \mathrm{g} / \mathrm{L}$} & 11 & 11 & TVS acute & 0.4 & 1.2 & -- & 13 to 17 & 0 \\
\hline & 11 & 11 & TVS chronic & 0.4 & 1.2 & 10 to 13 & -- & 0 \\
\hline Iron, dissolved, $\mu \mathrm{g} / \mathrm{L}$ & 12 & 9 & Fixed & 4 & 12 & 300 & -- & 0 \\
\hline Iron, total recoverable, $\mu \mathrm{g} / \mathrm{L}$ & 13 & 13 & Fixed chronic & 322 & 596,000 & 1,000 & -- & 9 \\
\hline \multirow[t]{2}{*}{ Lead, dissolved, $\mu \mathrm{g} / \mathrm{L}$} & 12 & 2 & TVS acute & 0.05 & 0.08 & -- & 44 & 0 \\
\hline & 12 & 2 & TVS chronic & 0.05 & 0.08 & 0.71 & -- & 0 \\
\hline \multirow[t]{3}{*}{ Manganese, dissolved, $\mu \mathrm{g} / \mathrm{L}$} & 12 & 12 & TVS acute & 0.1 & 33 & -- & 38 to 42 & 0 \\
\hline & 12 & 12 & TVS chronic & 0.1 & 33 & 32 to 34 & - & 0 \\
\hline & 12 & 12 & Fixed & 0.1 & 33 & 50 & -- & 0 \\
\hline Mercury, total recoverable, $\mu \mathrm{g} / \mathrm{L}$ & 11 & 2 & Fixed & 0.001 & 0.023 & 0.01 & -- & 2 \\
\hline \multirow[t]{2}{*}{ Zinc, dissolved, $\mu \mathrm{g} / \mathrm{L}$} & 11 & 11 & TVS acute & 0.5 & 1.1 & -- & 443 to 595 & 0 \\
\hline & 11 & 11 & TVS chronic & & & 98 to 124 & -- & 0 \\
\hline \multicolumn{9}{|c|}{ Lost Dog Creek } \\
\hline $\mathrm{pH}$, lab, standard units & 21 & 21 & Fixed & 6.6 & 7.9 & -- & 6.5 to 9.0 & 0 \\
\hline Chloride, dissolved, $\mathrm{mg} / \mathrm{L}$ & 21 & 20 & Fixed & 0.14 & 1.28 & -- & 250 & 0 \\
\hline Sulfate, dissolved, $\mathrm{mg} / \mathrm{L}$ & 21 & 21 & Fixed & 0.73 & 10.0 & -- & 250 & 0 \\
\hline \multirow[t]{2}{*}{ Ammonia, dissolved, $\mathrm{mg} / \mathrm{L}$} & 23 & 14 & TVS acute & 0.002 & 0.114 & -- & 6.8 to 24.1 & 0 \\
\hline & 23 & 14 & TVS chronic & 0.002 & 0.114 & 18.9 to 68.5 & -- & 0 \\
\hline Nitrate, dissolved, mg/L & 23 & 21 & Fixed & 0.007 & 0.946 & 10. & 10 & 0 \\
\hline Arsenic, dissolved, $\mu \mathrm{g} / \mathrm{L}$ & 7 & 7 & Fixed & 0.14 & 0.39 & -- & 340 & 0 \\
\hline Arsenic, total recoverable, $\mu \mathrm{g} / \mathrm{L}$ & 10 & 6 & Fixed & 0.25 & 2 & 0.02 & -- & 6 \\
\hline
\end{tabular}

Arsenic, total recoverable, $\mu \mathrm{g} / \mathrm{L}$

Fixed

0.25

2 
Table 13. Water-quality standards and exceedances of Colorado stream standards for sampling sites in this study.-Continued

[--, no data or no standard; $\mathrm{mg} / \mathrm{L}$, milligrams per liter; $\mu \mathrm{g} / \mathrm{L}$, micrograms per liter; $<$, less than; $\mathrm{mg} / \mathrm{L}$, milligrams per liter; $\mu \mathrm{g} / \mathrm{L}$, micrograms per liter; TVS, table value standards equation; standards from Colorado Department of Public Health and Environment, Water Quality Control Commission (2008); only data greater than or equal to the reporting limit were compared to standards; nitrite plus nitrate concentration is used instead of nitrate for comparison to standard as nitrite concentrations are generally negligible; uncensored samples without hardness for trace elements or water temperature and $\mathrm{pH}$ for ammonia samples were not included in the exceedance computations]

\begin{tabular}{|c|c|c|c|c|c|c|c|c|}
\hline \multirow{2}{*}{$\begin{array}{l}\text { Water-quality constituent } \\
\text { or measurement }\end{array}$} & \multirow{2}{*}{$\begin{array}{l}\text { Total number } \\
\text { of samples }\end{array}$} & \multirow{2}{*}{$\begin{array}{c}\begin{array}{c}\text { Total number } \\
\text { of uncensored } \\
\text { samples }\end{array} \\
\end{array}$} & \multirow{2}{*}{$\begin{array}{l}\text { Type of } \\
\text { standard }\end{array}$} & \multicolumn{2}{|c|}{ Range of concentration } & \multicolumn{2}{|c|}{ Standards } & \multirow{2}{*}{$\begin{array}{l}\text { Number of uncensored } \\
\text { sample exceedances }\end{array}$} \\
\hline & & & & Minimum & Maximum & Chronic & Acute & \\
\hline \multicolumn{9}{|c|}{ Lost Dog Creek-Continued } \\
\hline \multirow[t]{2}{*}{ Cadmium, dissolved, $\mu \mathrm{g} / \mathrm{L}$} & 16 & 1 & TVS acute, trout & 0.03 & 0.03 & -- & 0.2 & 0 \\
\hline & 16 & 1 & TVS chronic & 0.03 & 0.03 & 0.7 & -- & 0 \\
\hline \multirow[t]{2}{*}{ Copper, dissolved, $\mu \mathrm{g} / \mathrm{L}$} & 16 & 13 & TVS acute & 0.18 & 4.9 & -- & 1.6 to 4.4 & 1 \\
\hline & 16 & 13 & TVS chronic & 0.18 & 4.9 & 1.5 to 3.9 & -- & 1 \\
\hline Iron, dissolved, $\mu \mathrm{g} / \mathrm{L}$ & 16 & 16 & Fixed chronic & 17 & 195 & 300 & -- & 0 \\
\hline Iron, total recoverable, $\mu \mathrm{g} / \mathrm{L}$ & 16 & 16 & Fixed chronic & 51 & 10,000 & 1,000 & -- & 3 \\
\hline \multirow{2}{*}{ Lead, dissolved, $\mu \mathrm{g} / \mathrm{L}$} & 16 & 3 & TVS acute & 0.05 & 0.05 & -- & 4.2 to 10.5 & 0 \\
\hline & 16 & 3 & TVS chronic & 0.05 & 0.05 & 0.07 to 0.17 & -- & 0 \\
\hline \multirow{3}{*}{ Manganese, dissolved, $\mu \mathrm{g} / \mathrm{L}$} & 16 & 16 & TVS acute & 0.3 & 30 & -- & 17 to 26 & 1 \\
\hline & 16 & 16 & TVS chronic & 0.3 & 30 & 14 to 21 & -- & 2 \\
\hline & 16 & 16 & Fixed & 0.3 & 30 & 50 & -- & 0 \\
\hline Mercury, total recoverable, $\mu \mathrm{g} / \mathrm{L}$ & 11 & 4 & Fixed & 0.009 & 0.023 & 0.01 & -- & 3 \\
\hline \multirow[t]{2}{*}{ Zinc, dissolved, $\mu \mathrm{g} / \mathrm{L}$} & 16 & 9 & TVS acute & 0.6 & 3.7 & -- & 37 to 122 & 0 \\
\hline & 16 & 9 & TVS chronic & 0.6 & 3.7 & 47 to 129 & -- & 0 \\
\hline \multicolumn{9}{|c|}{ North Fork Elk River } \\
\hline $\mathrm{pH}$, lab, standard units & 21 & 21 & Fixed & 6.4 & 8.2 & -- & 6.5 to 9.0 & 1 \\
\hline Chloride, dissolved, $\mathrm{mg} / \mathrm{L}$ & 20 & 18 & Fixed & 0.1 & 1.0 & -- & 250 & 0 \\
\hline Sulfate, dissolved, $\mathrm{mg} / \mathrm{L}$ & 20 & 20 & Fixed & 1.1 & 9.4 & -- & 250 & 0 \\
\hline \multirow[t]{2}{*}{ Ammonia, dissolved, $\mathrm{mg} / \mathrm{L}$} & 23 & 12 & TVS acute & 0.002 & 0.042 & -- & 4 to 31 & 0 \\
\hline & 23 & 12 & TVS chronic & 0.002 & 0.042 & 10 to 89 & -- & 0 \\
\hline Nitrate, dissolved, mg/L & 23 & 21 & Fixed & 0.013 & 0.830 & -- & 10 & 0 \\
\hline Arsenic, dissolved, $\mu \mathrm{g} / \mathrm{L}$ & 8 & 7 & Fixed acute & 0.14 & 0.22 & -- & 340 & 0 \\
\hline Arsenic, total recoverable, $\mu \mathrm{g} / \mathrm{L}$ & 10 & 3 & Fixed chronic & 0.22 & 1 & 0.02 & -- & 3 \\
\hline \multirow[t]{2}{*}{ Cadmium, dissolved, $\mu \mathrm{g} / \mathrm{L}$} & 16 & 0 & TVS acute & $<0.037$ & $<1$ & -- & -- & 0 \\
\hline & 16 & 0 & TVS chronic & $<0.037$ & $<1$ & -- & -- & 0 \\
\hline \multirow[t]{2}{*}{ Copper, dissolved, $\mu \mathrm{g} / \mathrm{L}$} & 16 & 10 & TVS acute & 0.026 & 1.32 & -- & 2.0 to 5.1 & 0 \\
\hline & 16 & 10 & TVS chronic & 0.026 & 1.32 & 1.9 to 4.4 & -- & 0 \\
\hline Iron, dissolved, $\mu \mathrm{g} / \mathrm{L}$ & 16 & 16 & Fixed & 12 & 93 & 300 & -- & 0 \\
\hline Iron, total recoverable, $\mu \mathrm{g} / \mathrm{L}$ & 16 & 16 & Fixed chronic & 80 & 4,260 & 1,000 & -- & 2 \\
\hline \multirow[t]{2}{*}{ Lead, dissolved, $\mu \mathrm{g} / \mathrm{L}$} & 16 & 3 & Fixed acute & 0.04 & 0.06 & -- & 5.4 to 12.5 & 0 \\
\hline & 16 & 3 & Fixed chronic & 0.04 & 0.06 & 0.09 to 0.20 & -- & 0 \\
\hline \multirow[t]{3}{*}{ Manganese, dissolved, $\mu \mathrm{g} / \mathrm{L}$} & 16 & 16 & Fixed acute & 0.40 & 16.7 & -- & 19 to 28 & 0 \\
\hline & 16 & 16 & Fixed chronic & 0.40 & 16.7 & 16 to 22 & -- & 0 \\
\hline & 16 & 16 & Fixed & 0.40 & 16.7 & 50 & -- & 0 \\
\hline Mercury, total recoverable, $\mu \mathrm{g} / \mathrm{L}$ & 10 & 2 & Fixed & 0.011 & 0.011 & 0.01 & -- & 2 \\
\hline Zinc, dissolved, $\mu \mathrm{g} / \mathrm{L}$ & 16 & 6 & TVS acute & 0.5 & 1.7 & -- & 48 to 146 & 0 \\
\hline
\end{tabular}


low dissolved concentrations and limits bioavailability. Exceedances of Colorado water-quality standards in streams of both the Hayman and Hinman fire study areas only occurred for concentrations of five trace elements (not all trace-element exceedances occurred in every stream). Selected samples analyzed for total recoverable arsenic (fixed), dissolved copper (acute and chronic), total recoverable iron (chronic), dissolved manganese (acute, chronic, and fixed) and total recoverable mercury (chronic) exceeded Colorado aquatic-life standards. These exceedances (table 13) of Colorado standards are as follows (number of samples exceeded in parentheses for each stream): total recoverable arsenic (Fourmile, 1; South Platte Trumbull, 1; Lost Dog, 6; North Fork Elk, 3); dissolved copper (Lost Dog , 1); total recoverable iron (Fourmile, 33; Pine, 4; South Platte Trumbull, 9; Lost Dog, 3; North Fork Elk, 2); dissolved manganese (Fourmile, 9; Pine, 3; Lost Dog, 3); and total recoverable mercury (Fourmile, 18; Pine, 1; South Platte Trumbull, 2; Lost Dog, 3; North Fork Elk, 2). The lower standard for $\mathrm{pH}(\mathrm{pH}=6.5)$ was exceeded for one sample $(\mathrm{pH}=6.4)$ at North Fork Elk. In addition, many other unregulated water-quality constituents are potentially problematic after a fire, such as many nitrogen and phosphorus compounds, organic carbon, and suspended sediment.

Individual samples analyzed for total recoverable iron and total recoverable mercury exceeded concentrations computed from the Colorado stream-water-quality standards most frequently (table 13). Exceedances for total recoverable iron, total recoverable arsenic, and total recoverable mercury, which are commonly bound to soil and streambed sediments (source), generally occurred during periods of high suspendedsediment transport in all streams. The dissolved manganese and copper were probably naturally occurring from weathering of the geologic materials and release from burned vegetation in each watershed, but may exhibit enhanced mobility as a result of pyrolysis and fire-related processes.

\section{Summary}

In 2002, during a multiyear statewide drought that affected most of Colorado, several large fires occurred in Colorado. Two of these fires, the Hayman fire (about 35 miles (mi) southwest of Denver, Colorado), the largest known fire in Colorado history, burned about 138,000 acres and the Hinman fire (about 25 mi north of Steamboat Springs, Colorado), burned about 16,000 acres. Postfire effects on communities and water infrastructure including the increased potential for postfire flood, debris flow, sedimentation, and degradation of water supplies and water quality are problematic and costly to mitigate.

The U.S. Geological Survey began a 5-year study in 2003 that focused on postfire stream-water quality and postfire sediment load in streams affected by the Hayman and Hinman fires. This study was done in cooperation with many Federal, State, and local entities, including Douglas County; the U.S. Environmental Protection Agency; the cities of Aurora, Northglenn, Thornton, and Westminster; the Colorado
Department of Public Health and Environment; Colorado River Water Conservation District; Colorado Springs Utilities; Denver Water; Federal Emergency Management Agency; North Front Range Water Quality Planning Association; and Routt and Medicine Bow National Forests.

The purpose of this report is to compare and contrast the water quality of selected streams receiving runoff from unburned areas and burned areas affected by the Hayman and Hinman fires. Specific objectives of this report are to (1) conduct detailed analysis of the response of watersheds to fire by examining differences in concentrations and loads of nutrients, organic carbon, trace elements, and suspended sediment between streams receiving runoff from burned and unburned areas, and examine differences in watershed response between the two fire study areas; (2) investigate recovery of streamwater quality to prefire conditions using trend analysis; (3) discuss potential effects of postfire runoff on streams, lakes, and drinking-water treatment; and (4) identify postfire water-quality constituents that may be a concern to public health or aquatic biota. The scope of the study characterizes water quality primarily in one stream receiving runoff from an area burned by the Hayman fire (Fourmile Creek, hereinafter referred to as "Fourmile") and one similar nearby stream (Pine Creek, hereinafter referred to as "Pine") receiving runoff from an area that was not burned by the Hayman fire (hereinafter referred to as the "Hayman fire paired-watershed study").

The area burned by the Hayman fire ranges in elevation from about 6,500 to 10,000 feet (ft) and affected a major source area for Metropolitan Denver's raw water supply. The Hayman fire paired watersheds are about $8,000 \mathrm{ft}$ in elevation and are characterized by moderately steep slopes that are underlain by weathered Pikes Peak granite. Fourmile, which drains a burned watershed, flows northward and is about $9 \mathrm{mi}$ southwest from Pine, which drains an unburned watershed and generally flows north. The paired watersheds were selected for the study because they are similar in topography, slope, aspect, size, geology, and vegetation. The primary difference between the two watersheds is that the Hayman fire burned the Fourmile watershed, and the Pine watershed was not burned. Precipitation in the area of the Hayman fire study occurs predominantly as rain during the warmer months of the year (May through September) and snow during the colder months (October through April). Average annual precipitation is about 23 in. in the Fourmile watershed, and 24 in. in the Pine watershed.

The Hinman fire study area is topographically higher and wetter than the Hayman fire study area and ranges in elevation from 8,500 to $11,500 \mathrm{ft}$. The study area includes watersheds drained by the North Fork of the Elk River above mouth near Clark and the small tributary of Lost Dog Creek above mouth near Clark, which are hereinafter referred to as "North Fork Elk" and "Lost Dog." The study area is characterized by moderately steep, forested slopes and is underlain primarily by Precambrian igneous and metamorphic rocks. The mean annual precipitation in the study area is approximately 37 in., and most precipitation falls as snow. 
In the Hayman fire paired-watershed study, water and suspended-sediment samples were collected each year during the ice-free season (April-November) for 5 years (2003 through 2007). In the Hinman fire study area, water and suspended-sediment samples were collected during an earlier study by the USGS in two prefire years (1999 and 2000) and during this study in 2003, the year after the Hinman fire. The water-quality data collected during this study include onsite measurements of streamflow, specific conductance, and turbidity, and laboratory-determined concentrations of $\mathrm{pH}$, major ions, nutrients, organic carbon, trace elements, and suspended sediment. In 2003, tentatively identified organic compounds (TICs) also were determined in water and bed-sediment samples collected from selected streams that received runoff from burned areas of the Hayman and Hinman fires. Traceelement samples in bed sediment also were collected from selected streams that received runoff from burned areas of the Hayman and Hinman fires.

In the Fourmile and Pine watersheds, instantaneous streamflow measurements indicated that streamflows were generally highest most years in March through May, which corresponded to the snowmelt period. In some years, however, the highest instantaneous streamflows were probably caused by rainstorm runoff, as they were in 2003 at Fourmile. Timeseries trends in postfire instantaneous streamflow measurements in Fourmile and Pine were not statistically significant, as indicated by the seasonal Kendall analysis.

Two damaging floods were documented (others also occurred) during the course of the study that exemplified post-Hayman fire flood severity. One flood resulted from a May 2003 storm that produced 1 to $1.5 \mathrm{in}$. of rain over one-half of the Fourmile watershed and produced an estimated peak flow of 934 cubic feet per second $\left(\mathrm{ft}^{3} / \mathrm{s}\right)$, about 12 times the estimated 100-year recurrence interval flood. The other flood occurred in July 2006 after 2.2 in. of rain, which increased the flow in West Creek from $62 \mathrm{ft}^{3} / \mathrm{s}$ to $2,170 \mathrm{ft}^{3} / \mathrm{s}$ in about 45 min, causing approximately $\$ 11$ million in damages to Colorado State Highway 67.

In the Hinman area, postfire flooding also occurred. Despite an April 1 snow-water-equivalent that was near the 1999 through 2009 average, high runoff and local flooding were produced in 2003 in the burned area drained by the North Fork Elk (snowmelt peak measured 1,180 ft $\mathrm{ft}^{3} / \mathrm{s}$ ) and Lost Dog (snowmelt peak measured $174 \mathrm{ft}^{3} / \mathrm{s}$ ) watersheds, which were about 50 percent and 38 percent larger, respectively, than the estimated 100-year recurrence-interval flood. In addition to changes to soil surface runoff characteristics by fire, high streamflows may have been influenced by the 2003 snowpack that began melting in May rather than in April (a consequence of two late snowstorms) and melted more rapidly (possibly a consequence of less shading as a result of canopy removal by fire) than was indicated by the 11-year average. Peak streamflow data for the postburn 2003 period indicate that the smaller amount of snow-water-equivalent produced about a 30 percent increase in the annual peak streamflow than was predicted by the relation of peakflow and snow-water equivalent for the prefire years. Dissolved nitrite plus nitrate and orthophosphorus concentrations were generally one order of magnitude or larger in the first year postfire runoff (2003) collected from Fourmile than in samples collected from Pine. Similarly, total ammonia plus organic nitrogen and total phosphorus concentrations were generally one to three orders of magnitude larger in the first-year postfire runoff (2003) collected from Fourmile than in samples collected from Pine.

Median dissolved organic carbon (DOC) concentrations (2003-2007) in Fourmile (2.7 milligrams per liter (mg/L)) were similar to those in unburned Pine Creek (3.2 mg/L). Dissolved organic carbon concentrations were high in some storm runoff samples from Fourmile Creek, including three storms that had concentrations ranging from 10 to $30 \mathrm{mg} / \mathrm{L}$. Median total organic carbon (TOC) concentrations (2003-2007) in Fourmile $(7.1 \mathrm{mg} / \mathrm{L})$ were larger than concentrations in the unburned Pine watershed $(3.1 \mathrm{mg} / \mathrm{L})$.

Organic compound concentrations in runoff are known to increase during postfire runoff. In 2003, a limited number of water (seven samples collected from Fourmile and one sample collected from Pine) and bed-sediment samples (one each from Fourmile and Pine) were collected and analyzed for organic compounds. Many organic TICs were detected by qualitative gas chromatograph-mass spectrometer analysis (no calibrations to specific compounds were made) of stream water and bed sediment. Analytical results indicated a large number of TICs in both burned and unburned watersheds. One water sample collected from Fourmile Creek during the May 30, 2003, flood contained more than 200 organic TICs.

Comparison of paired instantaneous trace-element concentrations and loads at Fourmile and Pine using the Wilcoxon signed-rank test indicated larger concentrations in Fourmile (p-value $<0.10$ ) for dissolved and total recoverable concentrations of aluminum, arsenic, iron, and manganese but larger total recoverable concentrations in Fourmile only for cadmium, copper, lead, mercury, and zinc. Larger loads were computed for Fourmile than for Pine for dissolved and total recoverable iron and manganese, and for total recoverable aluminum, arsenic, cadmium, copper, lead, mercury, and zinc. Total recoverable trace-element concentrations in samples of runoff from both Fourmile and Pine were substantially larger (by several times) than dissolved trace-element concentrations, indicating that most trace elements were particulate.

Mercury was mostly analyzed as total recoverable mercury in this study, which includes both the dissolved and particulate fractions. The highest concentrations ranged to more than 0.381 microgram per liter $(\mu \mathrm{g} / \mathrm{L})$ and, when normalized to suspended-sediment concentration in the sample, was 0.0069 microgram per gram $(\mu \mathrm{g} / \mathrm{g})$. Mercury was related to high suspended-sediment concentration and was greater than the reporting level in samples that contained the highest concentrations of suspended sediment. The total recoverable mercury concentrations found in most samples indicate that substantial amounts of mercury related to suspended-sediment transport were mobilized from the burned Hayman watersheds.

For the Hinman fire study area, comparison of instantaneous nutrient concentrations and loads for prefire and postfire using the Mann-Whitney rank-sum test indicated 
larger postfire concentrations in Lost Dog ( $p$-value $<0.10)$ for total ammonia plus organic nitrogen, and dissolved ammonia, nitrite, nitrite plus nitrate, and total and dissolved phosphorus. Loads also were significantly larger ( $\mathrm{p}$-value $<0.10)$ for the same nutrients except dissolved nitrite and dissolved ammonia plus organic nitrogen and, at high streamflow, were sometimes several times higher than the prefire concentrations. Comparison of instantaneous nutrient concentrations and loads for prefire and postfire using the Mann-Whitney rank-sum test also indicated larger postfire nutrient concentrations in North Fork Elk (p-value $<0.10$ ) for dissolved nitrite, nitrite plus nitrate, ammonia, total ammonia plus organic nitrogen, total and dissolved phosphorus, and orthophosphorus, and larger loads for nitrite plus nitrate, ammonia, total ammonia plus organic nitrogen, total phosphorus, and orthophosphorus.

Median DOC and TOC concentrations from Lost Dog and North Fork Elk were similar (within about $1 \mathrm{mg} / \mathrm{L}$ ) to concentrations from a local unburned reference stream (Mad Creek). Mad Creek median DOC was $5.1 \mathrm{mg} / \mathrm{L}$ compared to $4.2 \mathrm{mg} / \mathrm{L}$ for postfire Lost Dog and $3.8 \mathrm{mg} / \mathrm{L}$ for postfire North Fork Elk. Median TOC concentration were also similar at postfire Lost Dog (5.2 mg/L) and North Fork Elk (5.6 mg/L) compared to the median of six samples collected from Mad Creek (4.9 mg/L) in 2003. Although higher concentrations of TOC were detected in the burned streams (maximum $35 \mathrm{mg} / \mathrm{L}$ ) than in the unburned stream (maximum $9.5 \mathrm{mg} / \mathrm{L}$ ) during high streamflow. These results may indicate that, in the snowmelt-dominated setting, postfire DOC concentrations may not increase or may be masked by dilution by the increase in postfire streamflow.

Comparison of instantaneous trace-element prefire and postfire concentrations and loads for Lost Dog using the Mann-Whitney rank-sum test indicated larger and statistically significant postfire concentrations ( $p$-value $<0.10$ ) for total recoverable iron and total recoverable manganese and larger loads for total recoverable manganese. Comparison of prefire and postfire instantaneous trace-element concentrations and loads for North Fork Elk using the Mann-Whitney rank-sum test indicated larger postfire concentrations ( $p$-value $<0.10$ ) for dissolved copper and total recoverable manganese but not for concentrations or loads of other trace elements.

Samples collected over a period of years following a wildfire, may indicate temporal trends related to recovery. To investigate temporal trends, 5 years of water-quality concentrations and loads for Fourmile and Pine (post-Hayman fire) were assessed using the seasonal Kendall test. Multiyear data were not collected following the Hinman fire, so temporal trends were not determined.

When concentrations at Fourmile were tested and a LOWESS streamflow adjustment was applied, downward trends (percent decrease per year over 5 years) were statistically significant ( $\mathrm{p}$-value $<0.10$ ) for specific conductance (-7.3), calcium (-11.8), magnesium (-8.82), potassium $(-10.9)$, total ammonia plus organic nitrogen $(-26.1)$, nitrite plus nitrate $(-17.4)$, total phosphorus $(-37.5)$, dissolved phosphorus $(-25.6)$, dissolved organic carbon $(-8.9)$, total recoverable arsenic $(-31)$, dissolved copper $(-8.8)$, dissolved manganese $(-48.5)$, total recoverable manganese $(-30.5)$, and total recoverable mercury $(-30.6)$.

When values and concentrations were tested and adjusted for streamflow using LOWESS at Pine (unburned reference site), temporal trends were downward and significant ( $\mathrm{p}$-value $<0.10)$ for total recoverable mercury $(-39.0)$ but were upward and significant for dissolved ammonia plus organic nitrogen $(+27.2)$, orthophosphorus $(+14.6)$, and dissolved organic carbon $(+12.8)$.

Estimated seasonal loads for selected constituents in samples from Fourmile and Pine for 2003 indicate that total loads normalized to drainage area at Fourmile for potassium, total nitrogen, nitrite plus nitrate, total phosphorus, orthophosphorus, total organic carbon, and total manganese were much larger than loads at Pine. Insufficient uncensored analytical results at Pine for total recoverable mercury prevented a comparison of loads for that constituent. No samples were collected in late summer 2002 from Fourmile, which may have excluded a substantial part of the postfire first-flush load.

Estimated seasonal water-quality constituent loads for selected constituents at North Fork Elk and Lost Dog for prefire (1999-2000) and postfire (2003) indicate that total postfire loads (normalized to drainage area) were larger than prefire loads for potassium, total nitrogen, nitrite plus nitrate, total phosphorus, and total manganese.

When total seasonal loads (normalized to drainage area) were compared among the burned watersheds evaluated in both the Hayman fire and Hinman fire study areas, no postfire loads at Hayman (Fourmile) were larger except for total recoverable manganese, which was similar. However, postfire loads of potassium, total nitrogen, nitrite plus nitrate, total phosphorus, and total organic carbon, and total recoverable mercury were largest at Lost Dog. Some of these loads could also be higher in the Hinman area as a result of enhanced nutrient transport as a result of the fallen dead timber from the Routt blowdown (a severe windstorm on October 25, 1997, that blew down more than 20,000 acres of forest) in addition to the effects of fire. Among the unburned site loads, Pine generally had the smallest constituent loads per square mile. No samples were collected in late summer 2002 at Fourmile, which may have excluded a substantial part of the postfire first-flush load and may render the implication that the snowmelt-dominated setting yielded greater unit loads than the rainfall-affected setting inconclusive.

Suspended-sediment concentrations in samples ranged from less than 1 to $83 \mathrm{mg} / \mathrm{L}$ at Pine (unburned watershed) and from 4 to $55,000 \mathrm{mg} / \mathrm{L}$ at Fourmile (burned watershed). Comparison of paired instantaneous suspended-sediment concentration and load at Fourmile and Pine using the Wilcoxon signed-rank test indicated larger values at Fourmile (p-value $<0.10$ ). Despite the findings by other research that snowmelt produces very little sediment erosion at the hillslope scale (a result of minor overland flow), in the Hayman burn area large suspended-sediment loads were transported in Fourmile during snowmelt periods, probably as a result of streambed and streambank erosion. 
Forty-thousand cubic yards (an estimated 59,000 tons) of sediment was excavated from the YMCA Camp Shady Brook Pond (Kiwanis Lake) on Fourmile from July 2002 to March 2005. The approximate annual yield for Fourmile was about 2,650 tons per square mile (tons $/ \mathrm{mi}^{2}$ ) per year over 3 years (or 10.2 tons per hectare per year over 3 years). This sediment yield was much smaller than the postfire median annual sediment yields of 220 tons per hectare for the regional precipitation regime (Plains medium) of the Hayman fire area documented in Moody and Martin in 2009, which were derived from measuring total sediment captured behind dams.

Trend testing of suspended-sediment concentrations and loads for 5 years postfire (2003-2007) at Fourmile and Pine were assessed using the seasonal Kendall test. When suspendedsediment concentrations (LOWESS-adjusted for streamflow) and load (not adjusted) at Fourmile were trend tested, there were no significant trends in turbidity, but downward trends (percent decrease per year over 5 years) in suspended-sediment concentration $(-47.2)$ and load $(-44.5)$ were statistically significant ( $\mathrm{p}$-value $<0.10$ ), indicating a substantial decrease in suspendedsediment concentration and load during the 5 -year period. When suspended-sediment concentrations (LOWESS-adjusted for streamflow) and load (not adjusted) at Pine were trend tested, there were no significant trends in turbidity or suspendedsediment concentration and load.

The suspended-sediment concentrations in samples ranged from less than 1 to $10 \mathrm{mg} / \mathrm{L}$ in prefire samples at Lost Dog (1999 and 2000) and from 3 to $565 \mathrm{mg} / \mathrm{L}$ in postfire samples (2003). The suspended-sediment concentrations in samples ranged from less than 1 to $21 \mathrm{mg} / \mathrm{L}$ in prefire samples at North Fork Elk (1999 and 2000) and from 2 to $305 \mathrm{mg} / \mathrm{L}$ in postfire samples (2003).

Total seasonal (April-September) suspended-sediment loads at Fourmile and Pine for the first postfire year (2003) indicate that loads (normalized to drainage area) at Fourmile $\left(1,160\right.$ tons $\left./ \mathrm{mi}^{2}\right)$ were almost three orders of magnitude larger than loads at Pine (3.22 tons $/ \mathrm{mi}^{2}$ ).

Estimated seasonal suspended-sediment loads at Lost Dog and North Fork Elk or prefire (1999) and postfire (2003) conditions indicate that suspended-sediment loads (normalized to drainage area) for postfire conditions were more than two orders of magnitude larger than prefire suspended-sediment loads at Lost Dog, and about one order of magnitude larger than prefire loads in North Fork Elk.

Streamflow and transport of water-quality constituents were substantially higher in the immediate (the first year after the fire) postburn condition and continue to be higher for years thereafter. Concentrations of almost every water-quality constituent were higher in streams receiving postfire runoff than in unburned reference streams. Loads in fire-affected streams were sometimes orders of magnitude larger than in unburned reference streams. The higher postfire streamflow documented in this study can destabilize channels and cause aggradation and degradation and (or) erosion of streambed and streambank material. Once fire disrupts hydraulic and sediment-transport equilibrium, channel bed and banks may take long periods to stabilize, especially in the watersheds underlain by weathered
Pikes Peak Granite (Hayman fire). Sediment also can degrade spawning habitat by covering or smothering gravels crucial to trout-spawning success and filling pools or covering riffles that are fish habitat. Fish kills were observed immediately following the Hayman fire and the first runoff events in some area streams and in Cheesman Lake. The Colorado Division of Wildlife has documented that trout populations in a reach of the South Platte River below Deckers went from 4,800 trout over 6 in. in length per mile (prior to most of the postfire runoff), to about 1,100 per mile in 2004 (after much of the postfire runoff). Population estimates in 2008 showed some recovery with about 1,800 trout per mile in the same reach.

The higher concentrations of nutrients in fire-affected streams as documented in this report, especially those that are generally considered to be bioavailable in the shortterm (ammonia, nitrate, orthophosphorus), can cause excess aquatic growth of periphyton or even rooted macrophytes. The increased algal productivity may disrupt the food web by changing functional feeding conditions for macroinvertebrates and fish, or cause problems such as clogging water intakes or filters at water-treatment plants. The high postfire organic carbon concentrations and loads measured in this study may react with dissolved oxygen in streams and reduce oxygen concentrations (chemical and biological oxygen demand) needed to sustain fish and other aquatic life.

The potential effects of large wildfires and post-wildfire nutrient loads on reservoirs may not be anticipated because many forests have not burned since the construction of many reservoirs, and water quality in reservoirs may take longer to recover to prefire conditions than water quality in streams. In this study, the total estimated 2003 seasonal load (April-September 2003) of phosphorus at South Platte Trumbull was almost 23,000 pounds. This load would have exceeded the allowable phosphorus load of 17,930 pounds (includes all sources upstream from Strontia Springs Reservoir outlet) for Chatfield Lake, located downstream near Denver, Colorado.

Several effects of postfire runoff described in this study can interfere with the treatment of drinking water. Postfire runoff can damage infrastructure such as reservoirs, intakes, diversion structures, and conveyances, which can interfere with diversion and transport of water to the treatment facility or reduce the operational efficiency of the treatment system. The potential abundance of fine sediment, organic matter, manganese, and taste and odor compounds may decrease the efficiency of treatment processes and the quality of finished drinking water.

Exceedances of 2008 Colorado water-quality standards in streams of both the Hayman and Hinman fire study areas only occurred for concentrations of five trace elements (not all trace-element exceedances occurred in every stream). Selected samples analyzed for total recoverable arsenic (fixed), dissolved copper (acute and chronic), total recoverable iron (chronic), dissolved manganese (acute, chronic, and fixed) and total recoverable mercury (chronic) exceeded 2008 Colorado aquatic-life standards. In addition, many other unregulated water-quality constituents are potentially problematic after fire, such as many nitrogen and phosphorus compounds, organic carbon, and suspended sediment. 


\section{Acknowledgments}

The author also gratefully acknowledges the useful insights provided by Garth Englund of Douglas County, Don Moore (formerly with Douglas County), and Ben Alexander (formerly with the City of Fort Collins Utilities). Thanks also to Merv Bennett, Clint Knox, and Mitch Walma of the YMCA of the Pikes Peak Region for access to YMCA Camp Shady Brook and for insight and observations of the postfire events at Fourmile.

\section{References}

Allan, J.D., 1995, Stream ecology — Structure and function of running waters: Great Britain, Chapman and Hall, 388 p.

Anderson, C.W., 2002, Ecological effects on streams from forest fertilization-Literature review and conceptual framework for future study in the western Cascades: U.S. Geological Survey Water-Resources Investigations Report 2001-4047, 49 p.

Barron, M.G., Carls, M.G., Heintz, R., and Rice, S.D., 2004, Evaluation of fish early life-stage toxicity models of chronic embryonic exposures to complex polycyclic aromatic hydrocarbon mixtures: Toxicological Sciences, v. 78, p. 60-67.

Bayley, S.E., Schindler, D.W., Parker, B.R., Stainton, M.P., and Beaty, K.G., 1992, Effects of forest fire and drought on acidity of a base-poor boreal forest stream-Similarities between climatic warming and acidic precipitation: Biogeochemistry, v. 17, no. 3, p. 191-204.

Benda, Lee, Miller, Daniel, Bigelow, Paul, and Andras, Kevin, 2003, Effect of post-wildfire erosion on channel environments, Boise River, Idaho: Forest Ecology and Management, v. 178, p. 105-119.

Biggs, B.J.F., Smith, R.A., and Duncan, M.J., 1999, Velocity and sediment disturbance of periphyton in headwater streams - Biomass and metabolism: Journal of the North American Benthological Society, v. 18, no. 2, p. 222-241.

Biswas, Abir, Blum, J.D., and Keeler, G.J., 2008, Mercury storage in surface soils in a central Washington forest and estimated release during the 2001 Rex Creek Fire: Science of the Total Environment, v. 404, p. 129-138.

Bitner, Kelly, Gallaher, Bruce, and Mullen, Ken, 2001, Review of wildfire effects on water quality: Los Alamos National Laboratory Report LA-13826-MS, 25 p.

Blackwelder, Eliot, 1926, Fire as an agent in rock weathering: Journal of Geology, v. 35, p. 134-140.

Brass, J.A., Ambrosia, V.G., Riggan, P.J., and Sebesta, P.D., 1996, Consequences of fire on aquatic nitrate and phosphate dynamics in Yellowstone National Park: International Journal of Wildland Fire, v. 6, p. 53-57.
Brenton, R.W., and Arnett, T.L., 1993, Methods of analysis by the U.S. Geological Survey National Water Quality Laboratory-Determination of dissolved organic carbon by -promoted persulfate oxidation and infrared spectrometry: U.S. Geological Survey Open-File Report 92-480, 12 p.

Brooks, K.N., Ffolliott, P.F, Gregersen, H.M., and DeBano, L.F., 2003, Hydrology and the management of watersheds: Ames, Iowa State Press, 574 p.

Cade-Menun, B.J., Berch, S.M., Preston, C.M., and Lavkulich, L.M., 2000, Phosphorus forms and related soil chemistry of Podzolic soils on northern Vancouver Island II-The effects of clear-cutting and burning: Canadian Journal of Forest Research, v. 30, no. 11, p. 1726-1741.

Campbell, W.G., and Morris, S.E., 1988, Hydrologic response of the Pack River, Idaho, to the Sundance fire: Northwest Science, v. 62, no. 4, p. 165-170.

Cannon, S.H., Gartner, J.E., Rupert, M.G., Michael, J.A., Rea, A.H., and Parrett, Charles, 2010, Predicting the probability and volume of postwildfire debris flows in the Intermountain Western United States: The Geological Society of America Bulletin, v. 122, nos. 1-2, p. 127-144.

Cannon, S.H., and DeGraff, J., 2009, The increasing wildfire and post-fire debris-flow threat in western USA, and implications for consequences of climate change, in Sassa, Kyoji, and Canuti, Philippo, eds., Landslides-Disaster risk reduction: Berlin, Springer Publishers, p. 177-190.

Carus Chemical Company, 2000, The potassium permanganate method for producing quality drinking water: Carus Chemical Company pamphlet, $6 \mathrm{p}$.

Ceam, R.V., Giovannini, G., and Luchesi, S., 2004, Mediterranean ecosystems - Soils, in Moreno, J., ed., 2004, Wildland fires impacts - A state of the art: Euro-Mediterranean Wildland Fire Laboratory Report D-04-03, 56 p., accessed October 28, 2009, at http://eufirelab.org/prive/directory/ units_section_4/D-04-03/D-04-03.pdf.

Certini, Giacomo, 2005, Effects of fire on properties of forest soils-A review: Oecologia, v. 143, p. 1-10.

Choromanska, U., and DeLuca, T.H., 2002, Microbial activity and nitrogen mineralization in forest mineral soils following heating - evaluation of post-fire effects: Soil Biology and Biochemistry, v. 34, p. 263-271.

Cleveland, W.S., and McGill, R., 1984, The many faces of scatterplot: Journal of the American Statistical Association, v. 79, p. $807-822$.

Cleveland, W.S., and McGill, R., 1985, Graphical perception and graphical methods for analyzing scientific data: Science, v. 229, p. 828-833.

Cole, G.A., 1994, Textbook of limnology: Prospect Heights, Illinois, Waveland Press, Inc., 412 p. 
Colorado Department of Local Affairs, 2002, Colorado wildfires 2002: Public information release, 5 p., accessed March 15, 2011, at http://dola.colorado.gov/dem/ public_information/co fires.pdf.

Colorado Department of Public Health and Environment, 2008a, Regulation no. 31, The basic standards and methodologies for surface water (amended January 14, 2008, effective May 31, 2008) (5 CCR 1002-31): Colorado Department of Public Health and Environment, Water Quality Control Commission, [variously paged].

Colorado Department of Public Health and Environment, 2008b, Regulation no. 33, Classification and numeric standards for Upper Colorado River Basin and the North Platte River (Planning area 12) (amended August 11, 2008, effective January 1, 2009): Colorado Department of Public Health and Environment, Water Quality Control Commission, [variously paged].

Colorado Department of Public Health and Environment, 2008c, Regulation no. 38, Classification and numeric standards for South Platte River Basin, Laramie River Basin, Republican River Basin, Smoky Hill River Basin (amended January 14, 2008, effective March 1, 2008): Colorado Department of Public Health and Environment, Water Quality Control Commission, [variously paged].

Colorado Department of Public Health and Environment, 2009, Regulation no. 73, Chatfield Reservoir control regulation (amended February 09, 2009, effective March 30, 2009): Colorado Department of Public Health and Environment, Water Quality Control Commission, 27 p., accessed September 4, 2009, at http://www.colorado.gov/cs/Satellite? blobcol=urldata\&blobheadername $1=$ Content-Disposition\& blobheadername $2=$ Content - Type $\&$ blobheadervalue $1=$ inlin $e \% 3 B+$ filename $\% 3 D \% 22$ Regulation+73.pdf\%22\&blobhea dervalue $2=$ application $\% 2 F p d f \&$ blobkey $=i d \&$ blobtable $=M$ ungoBlobs\&blobwhere $=1251810001057 \&$ ssbinary $=$ true .

Colorado Department of Transportation, 2006, Colorado Department of Transportation completes highway 67 reconstruction ahead of schedule: Colorado Department of Transportation press release, November 3, 2006, accessed March 15, 2011, at http://www.highbeam.com/ doc/1P3-1156462671.html.

Colorado Office of the State Engineer, 2004, Colorado Division of Water Resources 2004 Annual Report: Denver, Colo., Colorado Division of Water Resources, Department of Natural Resources, 8 p., accessed December 1, 2009, at http:// waterstate.co.us/DWRIPub/DWR\%20Annual\%20Reports/ annlrpt_2004.pdf.

Cottingham, Rick, 2005, Treatment techniques for wildfire affected drinking water supplies: Big Sky Clearwater, Montana Department of Environmental Quality, v. XXXV, issue 2, fall 2005, p. 21-22.
Crepeau, K.L., Fram, M.S., and Bush, Noël, 2004, Method of analysis by the U.S. Geological Survey California District Sacramento Laboratory-Determination of trihalomethane formation potential, method validation, and quality-control practices: U.S. Geological Survey Scientific Investigations Report 2004-5003, 21 p.

Crowfoot, R.M., Unruh, J.W., Steger, R.D., and O’Neill, G.B., 2001, Water resources data, Colorado, water year 2000, Volume 1: U.S. Geological Survey Water-Data Report CO-00-1, $499 \mathrm{p}$.

Crowfoot, R.M., Payne, W.F., and O’Neill, G.B., 2004, Water resources data, Colorado, water year 2003, Volume 1: U.S. Geological Survey Water-Data Report CO-03-1, 577 p.

Crowfoot, R.M., Payne, W.F., O'Neill, G.B., and Boulger, R.W., 2005, Water resources data, Colorado, water year 2004: U.S. Geological Survey Water-Data Report CO-04-1, $378 \mathrm{p}$.

DeBano, L.F., 2000, The role of fire and soil heating on water repellency in wildland environments-A review: Journal of Hydrology, v. 231-232, p. 195-206.

Desilets, S.L.E., Nijssen, B., Ekwurzel, B., and Ferre, T.P.A., 2007, Post-wildfire changes in suspended sediment rating curves - Sabino Canyon, Arizona: Hydrological Processes, v. 21, p. 1413-1423.

Dissmeyer, G.E., ed., 2000, Drinking water from forests and grasslands - A synthesis of the scientific literature: U.S. Department of Agriculture Forest Service General Technical Report SRS-39, 246 p.

Dodds, W.K., Bouska, W.W., Eitzmann, J.L., Pilger, T.J., Pitts, K.L., Riley, A.J., Schloesser, J.T., and Thornbrugh, D.J., 2009, Eutrophication of U.S. freshwaters-Analysis of potential economic damages: Environmental Science and Technology, v. 43, no. 1, p. 12-19.

Doesken, N.J., Pielke, R.A., and Bliss, O.A.P., 2003, Climate of Colorado - Climatography of the United States no. 60 (updated January 2003): Fort Collins, Colorado Climate Center, accessed September 1, 2009, at http://ccc.atmos.colostate.edu/climateofcolorado.php.

Driscoll, D.G., Carter, J.M., and Ohlen, D.O., 2004, Hydrologic effects of the 1988 Galena fire, Black Hills area, South Dakota: U.S. Geological Survey Water-Resources Investigations Report 03-4323, 67 p.

Driscoll, C.T., Han, Y., Chen, C.Y., Evers, D.C., Lambert, K.F., Holsen, T.M., Kamman, N.C., and Munson, R.K., 2007, Mercury contamination in forest and freshwater ecosystems in the northeastern United States: BioScience, v. 57 , no. 1, p. $17-28$.

Duan, Naihua, 1983, Smearing estimate-A non-parametric retransformation method: Journal of the American Statistical Association, v. 78, no. 383, p. 605-610. 
Dunham, J.B., Young, M.K., Gresswell, R.E., and Rieman, B.E., 2003, Effect of fire on fish populations - Landscape perspectives on persistence of native fishes and nonnative fish invasions: Forest Ecology and Management, v. 178, p. 183-196.

Earl, S.R., and Blinn, D.W., 2003, Effects of wildfire ash on water chemistry and biota in South-Western U.S.A. streams: Freshwater Biology, v. 48, no. 6, p. 1015-1030.

Elliott, J.G., Smith, M.E., Friedel, M.J., Stevens, M.R., Bossong, C.R., Litke, D.W., Parker, R.S., Costello, C., Wagner, J., Char, S.J., Bauer, M.A., and Wilds, S.R., 2005, Analysis and mapping of post-fire hydrologic hazards for the 2002 Hayman, Coal Seam, and Missionary Ridge wildfires, Colorado: U.S. Geological Survey Scientific Investigations Report 2004-5300, 104 p.

Engle, M.A., Sexauer Gustin, M., Johnson, D.W., Murphy, J.F., Miller, W.W., Walker, R.F., Wright, J., and Markee, M., 2006, Mercury distribution in two Sierran forest and one desert sagebrush steppe ecosystems and the effects of fire: Science of the Total Environment, v. 367, p. 222-233.

Fenneman, N.M., 1931, Physiography of the Western United States: New York, McGraw-Hill, 531 p.

Fenneman, N.M., and Johnson, D.W., 1946, Physiographic divisions of the conterminous U.S.: U.S. Geological Survey Special Map Series, scale 1:7,000,000.

Fishman, M.J., ed., 1993, Methods of analysis by the U.S. Geological Survey National Water Quality Laboratory-Determination of inorganic and organic constituents in water and fluvial sediments: U.S. Geological Survey Open-File Report 93-125, 217 p.

Fishman, M.J., and Friedman, L.C., 1989, Methods for determination of inorganic substances in water and fluvial sediments: U.S. Geological Survey Techniques of WaterResources Investigations, book 5, chap. A1, 545 p.

Fram, M.S., Fujii, R., Weishaar, J.L., Bergamaschi, B.A., and Aiken, G.R., 1999, How DOC Composition may explain the poor correlation between specific trihalomethane formation potential and specific UV absorbance, in Morganwalp, D.W., and Buxton, H.T., eds., U.S. Geological Survey Toxic Substances Hydrology Program-Proceedings of the Technical Meeting, Charleston, South Carolina, March 8-12, 1999-volume 2 of 3-Contamination of Hydrologic Systems and Related Ecosystems: U.S. Geological Survey Water-Resources Investigations Report 99-4018B, p. 423-430.

Fulton, R.A., 1999, Sensitivity of WSR-88D rainfall estimates to the rain-rate threshold and rain gauge adjustment- $\mathrm{A}$ flash flood case study: Weather and Forecasting, v. 14, no. 5, p. 604-624.

Gallaher, B.M., Koch, R.J., and Mullen, K., 2002, Quality of storm water runoff at Los Alamos National Laboratory in 2000 with emphasis on the impacts of the Cerro Grande fire: Los Alamos National Laboratory Report LA-13926, 54 p.
Gallaher, B.M., and Koch, R.J., 2004, Cerro Grande fire impacts to water quality and stream flow near Los Alamos National Laboratory-Results of four years of monitoring: Los Alamos National Laboratory Report LA-14177, 195 p.

Garbarino, J.R., and Damrau, D.L., 2001, Methods of analysis by the U.S. Geological Survey National Water Quality Laboratory-Determination of organic plus inorganic mercury in filtered and unfiltered natural water with cold vaporatomic fluorescence spectrometry: U.S. Geological Survey Water-Resources Investigations Report 01-4132, 16 p.

Garbarino, J.R., Kanagy, L.K., and Cree, M.E., 2006, Determination of elements in natural-water, biota, sediment and soil samples using collision/reaction cell inductively coupled plasma-mass spectrometry: U.S. Geological Survey Techniques and Methods, book 5, sec. B, chap.1, 88 p.

Garbarino, J.R., and Struzeski, T.M., 1998, Methods of analysis by the U.S. Geological Survey National Water Quality Laboratory-Determination of elements in wholewater digests using inductively coupled plasma-optical emission spectrometry and inductively coupled plasmamass spectrometry: U.S. Geological Survey Open-File Report 98-165, $101 \mathrm{p}$.

Garn, H.S., Elder, J.F., and Robertson, D.M., 2003, Why study lakes? An overview of USGS lake studies in Wisconsin: U.S. Geological Survey Fact Sheet 063-03, 8 p.

Gartner, J.E., Cannon, S.H., Santi, P.M., and Dewolfe, V.G., 2008, Empirical models to predict the volume of debris flows generated by recently burned basins in the western U.S.: Geomorphology, v. 96, p. 339-354.

Gill, D.D., 2004, The impacts of forest fires on drinking water quality: Arizona State University, M.S. thesis, 239 p.

Gilmour, C.C., Henry, E.A., and Mitchell, R., 1992, Sulfate stimulation of mercury methylation in freshwater sediments: Environmental Science and Technology, v. 26, no. 11, p. 2281-2287.

Giovannini, C., Lucchesi, S., and Giachetti, M., 1990, Effects of heating on some chemical parameters related to soil fertility and plant growth: Soil Science, v. 149, no. 6, p. 344-350.

Gonzalez-Perez, J.A., Gonzalez-Vila, F.J., Almendros, G., and Knicker, H., 2004, The effect of fire on soil organic matter-A review: Environmental International, v. 30, p. 855-870.

Graham, R.T., ed., 2003, Hayman Fire case study: U.S. Department of Agriculture Forest Service, Rocky Mountain Research Station, General Technical Report RMRS-GTR-114, 369 p.

Gresswell, R.E., 1999, Fire and aquatic ecosystems in forested biomes of North America: Transactions of the American Fisheries Society, v. 128, p. 193-221. 
Hall, S.J., and Lombardozzi, D., 2008, Short-term effects of wildfire on montane stream ecosystems in the southern Rocky Mountains - One and two years post-burn: Western North American Naturalist, v. 68, no. 4, p. 453-462.

Hauer, F.R., and Spencer, C.N., 1998, Phosphorus and nitrogen dynamics in streams associated with wildfire-A study of immediate and long term effects: International Journal of Wildland Fire, v. 8, no. 4, p. 183-198.

Helsel, D.R., 2005, Nondetects and data analysis-Statistics for censored environmental data: New York, John Wiley and Sons, $250 \mathrm{p}$.

Helsel, D.R., and Hirsch, R.M., 1992, Statistical methods in water resources: New York, Elsevier Studies in Environmental Science, v. 49, 529 p.

Helvey, J.D., 1973, Watershed behavior after forest fire in Washington, in Proceedings of the Irrigation and Drainage Division Specialty Conference, April 22-24, 1973, Fort Collins, Colo.: American Society of Civil Engineers, p. 403-422.

Helvey, J.D., 1980, Effects of a north-central Washington wildfire on runoff and sediment production: Water Resources Bulletin, v. 16, no. 4, p. 627-634.

Hem, J.D., 1985, Study and interpretation of the chemical characteristics of natural water ( $3 d$ ed.): U.S. Geological Survey Water-Supply Paper 2254, 263 p.

Hoffman, G.L., Fishman, M.J., and Garbarino, J.R., 1996, Methods of analysis by the U.S. Geological Survey National Water Quality Laboratory-In-bottle acid digestion of whole-water samples: U.S. Geological Survey Open-File Report 96-225, 28 p.

Horne, A.J., and Goldman, C.R., 1994, Limnology (2d ed.): New York, McGraw Hill, 576 p.

Jarrett, R.D., 1990, Hydrologic and hydraulic research in mountain rivers: Water Resources Bulletin, v. 26, p. 419-429.

Kelly, E.N., Schindler, D.W., St. Louis, V.L., Donald, D.B., and Vladicka, K.E., 2006, Forest fire increases mercury accumulation by fishes via food web restructuring and increased mercury inputs: Washington, D.C., Proceedings of the National Academy of Sciences of the United States of America, v. 103, no. 51, p. 19380-19385.

Kershner, J.L., MacDonald, L., Decker, L.M., Winters, D., and Libohova, Z., 2003, in Graham, R.T., technical ed., 2003, Hayman Fire case study: U.S. Department of Agriculture, Forest Service, Rocky Mountain Research Station, Gen. Tech. Rep. RMRS-GTR-114, 396 p.

Kulakowski, Dominik, and Veblen, T.T., 2007, Effect of prior disturbances on the extent and severity of wildfire in Colorado subalpine forests: Ecology, v. 88, no. 3, p. 759-769.
Landsberg, J.D., and Tiedemann, A.R., 2000, Fire management, in Dissmeyer, G.E., ed., Drinking water from forests and grasslands - A synthesis of the scientific literature: U.S. Department of Agriculture Forest Service General Technical Report SRS-39, p. 124-138.

LeMaster, D.C., Shao, Guofan, and Donnay, Jacob, 2007, Protecting Front Range forest watersheds from high-severity wildfires: Pinchot Institute for Conservation, $47 \mathrm{p}$.

Larsen, I.J., MacDonald, L.H., Brown, E., Rough, D., Welsh, M.J., Pitraszek, J.H., Benavides-Solorio, Juan, de Dios, Libohova, Z., and Schaffrath, K., 2009, Causes of post-fire runoff and erosion-Water repellency cover, or soil sealing?: Soil Science Society of America Journal, v. 73, no. 4, p. 1393-1407.

Leib, K.J., and von Guerard, P.B., 2003, Data summary and loading sources for selected water-quality characteristics of streams in blowdown areas, North Fork Elk River watershed, Colorado, March 1999-August 2000: U.S. Geological Survey Fact Sheet 127-02, 6 p.

Libohova, Zamir, 2004, Effects of thinning and a wildfire on sediment production rates, channel morphology, and water quality in the upper South Platte River watershed: Fort Collins, Colorado State University, M.S. thesis, 104 p.

Licis, Karl, 2009, South Platte River sees rapid recovery: Denver Post online article, July 15, 2009, 4 p., accessed December 15, 2009, at http://www.denverpost.com/ extremes/ci_12838578.

MacDonald, L.H., and Robichaud, P.R., 2008, Post-fire erosion and the effectiveness of emergency rehabilitation treatments over time: U.S. Department of Agriculture Forest Service Rocky Mountain Research Station, Stream Systems Technology Center, Stream Notes, January 2008, p. 1-6.

MacDonald, L.H., Smart, A., and Wissmar, R.C., 1991, Monitoring guidelines to evaluate effects of forestry activities on streams in the Pacific Northwest and Alaska: U.S. Environmental Protection Agency Report EPA/910/9-91-001, 166 p., accessed December 2013 at http://cfpub.epa.gov/ols/catalog/ advanced_brief_record.cfm? \&FIELD $4=C A L L N U M \& I N P U$ $T 4=E P A / 910 / 9-91-001 \& L O G I C 4=A N D \& C O L L=\& S O R T_{-}$ TYPE $=Y R D E S C \&$ item_count $=1 \& i t e m \_a c c n=380095$.

Maloney, T.J., ed., 2005, Quality management system, U.S. Geological Survey National Water Quality Laboratory: U.S. Geological Survey Open-File Report 2005-1263, version 1.3, November 9, 2005, [chapters and appendixes variously paged].

Martin, D.A., and Moody, J.A., 2001, Comparison of soil infiltration rates in burned and unburned mountainous watersheds: Hydrological Processes, v. 15, no. 15, p. 2893-2903.

Mast, M.A., and Clow, D.W., 2008, Effect of 2003 wildfires on stream chemistry in Glacier National Park, Montana: Hydrological Processes, v. 22, p. 5013-5023. 
Mayor, A.G., Bautista, S., Llovet, J., and Bellot, J., 2007, Postfire hydrological and erosional responses of a Mediterranean landscape-Seven years of catchment-scale dynamics: Catena, v. 71, p. 68-75.

Meixner, Tom, and Wohlgemuth, Pete, 2004, Wildfire impacts on water quality: Southwest Hydrology, September/October issue, p. 24-25.

Meixner, Tom, Fenn, M.E., Wohlgemuth, Pete, Oxford, M., and Riggan, P., 2006, N saturation symptoms in chaparral catchments are not reversed by prescribed fire: Environmental Science and Technology, v. 40, no. 9, p. 2887-2894.

Meyer, J.P., 2006, Hayman fire still mucking up water: Denver Post, November 24, 2006, p. 1 A.

Minshall, G.W., Brock, J.T., and Varley, J.D., 1989, Wildfires and Yellowstone's stream ecosystems: Bioscience, v. 39, no. 10, p. 707-715.

Minshall, G.W., Robinson, C.T., and Lawrence, D.E., 1997, Postfire responses of lotic ecosystems in Yellowstone National Park, U.S.A.: Canadian Journal of Fisheries and Aquatic Science, v. 54, p. 2509-2525.

Moody, J.A., 2001, Sediment transport regimes after a wildfire in steep mountainous terrain, in Proceedings of the Seventh Federal Interagency Sedimentation Conference, March 25-29, 2001, Reno, Nevada: U.S. Subcommittee on Sedimentation, A Subcommittee of the Advisory committee on Water Information (ACWI), chap. 10, p. X-41-X-48.

Moody, J.A., and Martin, D.A., 2001a, Initial hydrologic and geomorphic response following a wildfire in the Colorado Front Range: Earth Surface Processes and Landforms, v. 26, p. 1049-1070.

Moody, J.A., and Martin, D.A., 2001b, Hydrological and sedimentologic response of two burned watersheds in Colorado: U.S. Geological Survey Water-Resources Investigations Report 2001-4122, 142 p.

Moody, J.A., and Martin, D.A., 2009, Synthesis of sediment yields after wildland fire in different rainfall regimes in the Western United States: International Journal of Wildland Fire, 2009, v. 18, p. 96-115.

Murphy, S.F., McCleskey, R.B., and Writer, J.H., 2012, Effects of flow regime on stream turbidity and suspended solids after wildfire, Colorado Front Range, USA, in Wildfire and Water Quality_-Processes, impacts and challenges-Proceedings of a conference held in Banff, Canada, June 11-14, 2012: Wallingford, United Kingdom, International Association of Hydrological Sciences, IAHS Press, IAHS publication no. 354, p. 51-58.

National Drinking Water Clearinghouse, 1998, Iron and manganese removal: National Drinking Water Clearinghouse Fact Sheet, Tech Brief, v. 9, 4 p.
Neary, D.G., Klopatek, C.C., DeBano, L.F., and Ffolliott, P.F., 1999, Fire effects on belowground sustainability-A review and synthesis: Forest Ecology and Management, v. 122, p. 51-71.

Neary, D.G., Ryan, K.C., and DeBano, L.F., eds., 2008, Wildland fire in ecosystems - effects on soils and water [revised from 2005]: Ogden, Utah, U.S. Department of Agriculture, Forest Service, Rocky Mountain Research Station, General Technical Report RMRS-GTR-42, v. 4, 250 p.

Nitschke, C.R., 2005, Does forest harvesting emulate fire disturbance? A comparison of effects on selected attributes in coniferous-dominated headwater systems: Forest Ecology and Management, v. 214, p. 305-319.

O’Dell, J.W., Pfaff, J.D., and Budde, W.L., 1993, Methods for the determination of inorganic substances in environmental samples: U.S. Environmental Protection Agency Report EPA/600/R-93/100, 172 p.

Oros, D.R., Mazurek, M.A., Baham, J.E., and Simoneit, B.R.T., 2002, Organic tracers from wildfire residues in soils and rain/river wash-out: Water, Air, and Soil Pollution, v. 137 , p. 203-233.

Parkhill, K.L., and Gulliver, J.S., 2002, Effect of inorganic sediment on whole-stream productivity: Hydrobiologia, v. 472, p. 5-17.

Parra, J.G., Rivero, V.C., and Lopez, T.I., 1996, Forms of Mn in soils affected by a forest fire: Science of the Total Environment, v. 181, p. 231-236.

Parrett, Charles, and Johnson, D.R., 1994, Estimates of monthly streamflow characteristics and dominant-discharge hydrographs for selected sites in the Lower Missouri and Little Missouri River basins in Montana: U.S. Geological Survey Water-Resources Investigations Report 94-4098, 29 p.

Parvez, Shahid, Venkataraman, Chandra, and Mukherji, Suparna, 2009, Nature and prevalence of non-additive toxic effects in industrially relevant mixtures of organic chemicals: Chemosphere, v. 75, p. 1429-1439.

Patton, C.J., and Truitt, E.P., 2000, Methods of analysis by the U.S. Geological Survey National Water Quality Laboratory-Determination of ammonium plus organic nitrogen by a Kjeldahl digestion method and an automated photometric finish that includes digest cleanup by gas diffusion: U.S. Geological Survey Open-File Report 00-170, 31 p.

Perry, C.H., Amacher, M.C., Cannon, W., Kolka, R.K., and Woodruff, L., 2006, The distribution of mercury in a forest floor transect across the central United States, in 2006 Proceedings of the Eighth Annual Forest Inventory and Analysis Symposium, October 16-19, 2006, Monterey, Calif.: Washington, D.C., U.S. Department of Agriculture Forest Service, Gen. Tech. Report WO-79, p. 103-108.

Pietraszek, J.H., 2006, Controls on post-fire erosion at the hillslope scale, Colorado Front Range: Fort Collins, Colorado State University, M.S. thesis, 124 p. 
Planas, Dolors, Desrosiers, Mélanie, Groulx, S.R., Paquet, S., and Carignan, R., 2000 Pelagic and benthic algal responses in eastern Canadian Boreal Shield lakes following harvesting and wildfires: Canadian Journal of Fisheries and Aquatic Science, v. 57, supplement 2, p. 136-145.

Plumlee, G.S., Martin, D.A., Hoefen, T., Kokaly, R., Hageman, A.E., Meeker, G.P., Adams, M., Anthony, M., and Lamothe, P.J., 2007, Preliminary analytical results for ash and burned soils from the October 2007 California Wildfires: U.S. Geological Survey Open-File Report 2007-1407, $14 \mathrm{p}$.

Ranalli, A. J., 2004, A summary of the scientific literature on the effects of fire on the concentration of nutrients in surface waters: U.S. Geological Survey Open-File Report 2004-1296, 23 p. (Available at http://pubs.usgs.gov/ of/2004/1296/.)

Ranalli, A.J., and Stevens, M.R., 2004, Streamwater quality data from the 2002 Hayman, Hinman, and Missionary Ridge wildfires, Colorado: U.S. Geological Survey Data Series Report 2004-109, 5 p.

Rantz, S.E., and others, 1982, Measurement and computation of streamflow-Volume 1, Measurement of stage and discharge, and volume 2, Computation of discharge: U.S. Geological Survey Water-Supply Paper 2175, 630 p.

Reeves, G.H., Benda, L.E., Burnett, K.M., Bisson, P.A., and Sedell, J.R., 1995, A disturbance-based ecosystem approach to maintaining and restoring freshwater habitats of evolutionarily significant units of anadromous salmonids in the Pacific Northwest: American Fisheries Society Symposium, v. 17, p. 334-349.

Rhoades, Chuck, Entwistle, Deb, and Butler, Dana, 2006, Initial streamwater response to the Hayman Fire, Colorado Front Range, in Fowler, D.L., compiler, Second Interagency Conference on Research in the Watersheds - Challenges and opportunities for watershed research, May 16-18, 2006, Coweeta Hydrologic Laboratory, Otto, North Carolina, Proceedings: U.S. Department of Agriculture, Agricultural Research Service, p. 89-98.

Richardson, S.D., Plewa, M.J., Wagner, E.D., Schoeny, R., and DeMarini, D.M., 2007, Occurrence, genotoxicity, and carcinogenicity of regulated and emerging disinfection by-products in drinking water-A review and roadmap for research: Mutation Research, v. 636, nos. 1-3, p. 178-242.

Rodebaugh, Dale, 2005, Volunteers monitor Vallecito Reservoir: Durango Herald, November 3, 2005, accessed December 18, 2009, at http://archive.durangoherald.com/asp-bin/ printable_article_generation.asp?article_path=/earth/ earth051103_2.htm.

Rumbaitis del Rio, C.M., 2006, Changes in understory composition following catastrophic windthrow and salvage logging in a subalpine forest ecosystem: Canadian Journal of Forest Research, v. 36, p. 2943-2954.
Satterfield, Zane, 1998, Jar testing: National Environmental Services Center at West Virginia University, National Drinking Water Clearinghouse Fact Sheet, Tech Brief, v. 5, no. 1, 4 p.

Satterfield, Zane, 2006a, Taste and odor control: National Environmental Services Center at West Virginia University, National Drinking Water Clearinghouse Fact Sheet, Tech Brief, v. 6, no. 1, 4 p.

Satterfield, Zane, 2006b, Turbidity control: National Environmental Services Center at West Virginia University, National Drinking Water Clearinghouse Fact Sheet, Tech Brief, v. 6, no. 2, 4 p.

Sillanpää, Markus, Saarikoski, Sanna, Hillamo, Risto, Pennanen, Arto, Makkonen, Ulla, Spolnik, Zoya, Van Grieken, René, Koskentalo, Tarja, and Salonen, Raimo, 2005, Chemical composition, mass size distribution and source analysis of longrange transported wildfire smokes in Helsinki: Science of the Total Environment, v. 350, p. 119-135.

Simoneit, B.R.T., Rogge, W.F., Lang, Q., and Jaffe, R., 2000, Molecular characterization of smoke from campfire burning of pine wood (Pinus elliottii): Chemosphere-Global Change Science, v. 2, p. 107-122.

Skyllberg, Ulf, Björkman Westin, M., Meili, Markus, and Björn, Erik, 2009, Elevated concentrations of methylmercury in streams after forest clear cut-A consequence of mobilization from soil or new methylation?: Environmental Science and Technology, v. 43, no. 22, p. 8535-8541, accessed December 1, 2009, at http://pubs.acs.org/doi/ full/10.1021/es900996z.

Smith, K.S., 2007, Strategies to predict metal mobility in surficial mining environments: Reviews in Engineering Geology, v. 17 , p. $25-45$.

Smithwick, E.A.H., Turner, M.G., Mack, M.C., and Chapin, F.S., 2005, Postfire soil N cycling in northern conifer forests affected by severe stand-replacing wildfires: Ecosystems, v. 8, p. 163-181.

Spencer, C.N., Gabel, K.O., and Hauer, F.R., 2003, Wildfire effects on stream food webs and nutrient dynamics in Glacier National Park, USA: Forest Ecology and Management, v. 178 , p. 141-153.

Stein, E.D., 2008, Effects of southern California wildfires on storm water metals and PAHs: Southern California Coastal Water Research Project presentation, accessed October 16, 2009, at ftp://ftp.sccwrp.org/pub/download/ PRESENTATIONS/Symposium09/ContaminantTransport_ 1_Stein_FireEffects.pdf.

Stevens, M.R., Bossong, C.R., Rupert, M.G., Ranalli, A.J., Cassidy, E.W., Druliner, A.D., 2008a, Post-wildfire hydrologic hazards in the wildland urban interface of Colorado and the Western United States: U.S. Geological Survey Fact Sheet 2007-3036, 6 p. 
Stevens, M.R., Bossong, C.R., Litke, D.W., Viger, R.J., Rupert, M.G., and Char, S.J., 2008b, Estimated probability of post-wildfire debris-flow occurrence and estimated volume of debris flows from a pre-fire analysis in the Three Lakes Watershed, Grand County, Colorado: U.S. Geological Survey Scientific Investigations Map 3009, 1 sheet.

Tweto, O.L., 1979, Geologic map of Colorado: U.S. Geological Survey Special Map, scale 1:500,000.

U.S. Department of Agriculture, National Resources Conservation Service, 2009, Colorado SNOTEL sites: U.S. Department of Agriculture, National Resources Conservation Service, National Water and Climate Center, accessed January 10, 2009, at http://www.wcc.nrcs.usda.gov/snotel/ Colorado/colorado.html.

U.S. Environmental Protection Agency, 2002, 2002 Edition of the drinking water standards and health advisories: Washington, D.C., U.S. Environmental Protection Agency, Office of Water, EPA 822-12-02-038, 12 p.

U.S. Geological Survey, 2002, The USGS role in TMDL assessments: U.S. Geological Survey Fact Sheet FS-130-01 (Version 1.1), 4 p. (Also available at http://pubs.usgs.gov/fs/ FS-130-01/.)

U.S. Geological Survey, 2002, Processing of water samples, in Wilde, F.D., 2002, National field manual for the collection of water-quality data: U.S. Geological Survey Techniques of Water-Resources Investigations, book 9, chap. A5, [variously paged].

U.S. Geological Survey, 2006, Wildfire hazards-A national threat: U.S. Geological Survey Fact Sheet 2006-3015, 2 p.

U.S. Geological Survey, 2009, Streamstats-A water resources web application: U.S. Geological Survey database, accessed March 2009, at http://water.usgs.gov/osw/streamstats/ colorado.html.

U.S. Geological Survey, 2012, Geospatial multi-agency coordination group (GeoMAC) internet-based mapping application: U.S. Geological Survey database, accessed May 2012, at http://www.geomac.gov/index.shtml.

Vaill, J.E., 2000, Analysis of the magnitude and frequency of floods in Colorado: U.S. Geological Survey WaterResources Investigations Report 99-4190, 35 p.

Veenhuis, J.E., 2002, Effects of wildfire on the hydrology of Capulin and Rito de Los Frijoles canyons, Bandelier National Monument, New Mexico: U.S. Geological Survey Water-Resources Investigations Report 2002-4152, 39 p.
Volk, Christian, Kaplan, L.A., Robinson, J., Johnson, B., Wood, L., Zhu, H.W., and Lechevallier, M., 2005, Fluctuations of dissolved organic matter in river used for drinking water and impacts on conventional treatment plant performance: Environmental Science and Technology, v. 39, p. $4258-4264$.

Wan, Shiqiang, Hui, Dafeng, and Luo, Yiqi, 2001, Fire effects on nitrogen pools and dynamics in terrestrial ecosystemsA meta-analysis: Ecological Applications, v. 11, no. 5, p. 1349-1365.

Ward, A.D., and Elliot, W.J., 1995, Environmental hydrology: Boca Raton, Florida, CRC Press, 462 p.

Westerling, A.L., Hidalgo, H.G., Cayan, D.R., and Swetnam, T.W., 2006, Warming and earlier spring increase western U.S. forest wildfire activity: Science, v. 313, p. 940-943.

Western Regional Climate Center, 2009, Colorado climate summaries, Cheesman station: Reno, Nev.: Western Regional Climate Center, accessed January 20, 2009, at http://www.wrcc.dri.edu/summary/climsmco.html.

Woods, P.F., 1992, Limnology of Big Lake, south-central Alaska, 1983-84: U.S. Geological Survey Water-Supply Paper 2382, $108 \mathrm{p}$.

Woodsmith, R.D., Vache, K.B., McDonnnell, J.J., Seibert, J., and Helvey, J.D., 2007, The Entiat Experimental Forest—A unique opportunity to examine hydrologic response to wildfire, in Furniss, M.J., Clifton, C.F., and Ronnenberg, K.I., eds., 2007, Advancing the fundamental sciences-Proceedings of the Forest Service National Earth Sciences Conference, San Diego, Calif., October 18-22, 2004: U.S. Department of Agriculture Forest Service Pacific Northwest Research Station, General Technical Report PNW-GTR-689, p. 205-216.

Wright, W.G., 2005, Water-quality trends in the upper Los Piños River watershed: Southwest Hydrology, July-August 2005 issue, p. 8-9.

Writer, J.H., McClelskey, R.B., and Murphy, S.F., 2012, Effects of wildfire on source-water quality and aquatic ecosystems, Colorado Front Range-Proceedings of a conference held in Banff, Canada, June 11-14, 2012: Wallingford, United Kingdom, International Association of Hydrological Sciences, IAHS Press, IAHS publication no. 354, p. 117-122.

Zhong, Huan, and Wang, Wen-Xiong, 2006, Sediment-bound inorganic $\mathrm{Hg}$ extraction mechanisms in the gut fluids of marine deposit feeders: Environmental Science and Technology, v. 40, p. 6181-6186. 

Appendixes 

Appendix 1. Field measurements, concentrations, loads, and flow-weighted measurements for Fourmile, Pine, South Platte Trumbull, Lost Dog, North Fork Elk, and Mad Creek sampling sites, 1999-2007

Appendix 2. Statistics for concentrations, measurement values, loads, and flow-weighted measurements at water-quality sampling sites, 1999-2007

Appendix 3. Tentatively identified organic compounds detected in water samples samples for selected sites

Appendix 4. Tentatively identified organic compounds detected in bed-sediment samples for selected sites

Appendix 5. Statistics for computed relative percent differences among sequential replicates collected during the study

Appendix 6. Selected statistics for field blank samples

Appendix 7. Trihalomethane formation (THM) potential concentrations from selected sites in the Hayman and Hinman fire study areas and streams in the Missionary Ridge fire area west of Durango, Colorado

Appendix 8. Concentrations of target organic compounds in water samples collected at selected sites

Appendix 9. Concentrations of trace elements detected in bed-sediment samples collected from selected sites

Appendix 10. Supplemental data collected by the U.S. Department of Agriculture Forest Service before and after the June 2002 Hayman fire

Appendix 11. Comparison of Hayman and Hinman fire study areas' minimum, median, and maximum concentrations and loads, April through September 2003 (first year after fire)

Appendix 12. Location of Mad Creek water-quality sampling site south of North Fork Elk River near mouth near Clark, Colorado

Publishing support provided by:

Denver Publishing Service Center, Denver, Colorado

For more information concerning this publication, contact:

Director, USGS Colorado Water Science Center

Box 25046, Mail Stop 415

Denver, C0 80225

(303) 236-4882

Or visit the Colorado Water Science Center Web site at:

http://co.water.usgs.gov/

This publication is available online at:

http://dx.doi.org/10.3133/sir20125267 

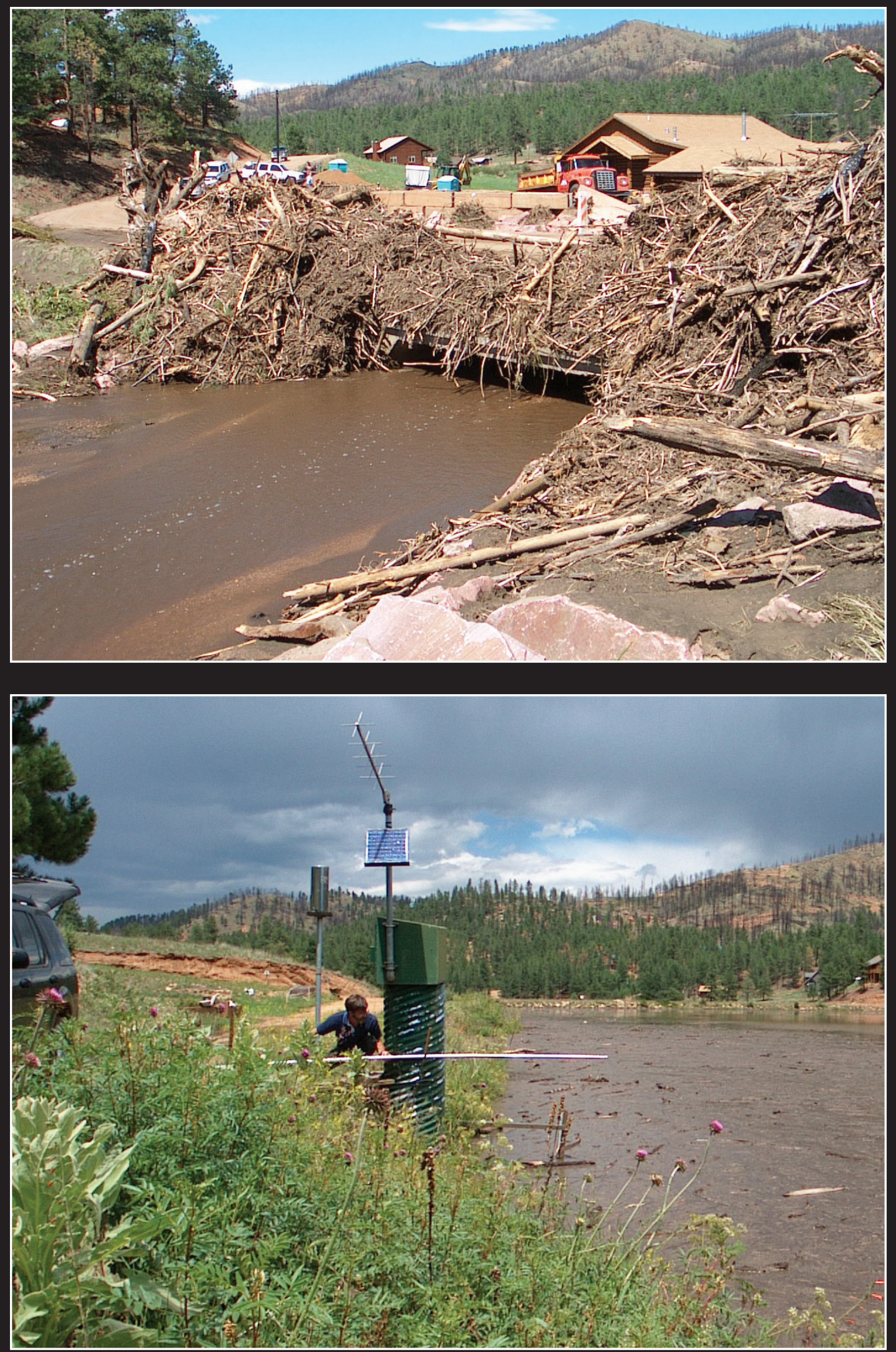

ISSN 2328-0328 (online)

http://dx.doi.org/10.3133/sir20125267 